\title{
Schoolverlaters tussen onderwijs en arbeidsmarkt 2002
}

Citation for published version (APA):

Wolbers, M. H. J., \& de Vries, M. R. (2003). Schoolverlaters tussen onderwijs en arbeidsmarkt 2002:

Statistische Bijlage. ROA. ROA Reports No. 009B https://doi.org/10.26481/umarep.2003009B

Document status and date:

Published: 01/01/2003

DOI:

10.26481/umarep.2003009B

Document Version:

Publisher's PDF, also known as Version of record

\section{Please check the document version of this publication:}

- A submitted manuscript is the version of the article upon submission and before peer-review. There can be important differences between the submitted version and the official published version of record.

People interested in the research are advised to contact the author for the final version of the publication, or visit the DOI to the publisher's website.

- The final author version and the galley proof are versions of the publication after peer review.

- The final published version features the final layout of the paper including the volume, issue and page numbers.

Link to publication

\footnotetext{
General rights rights.

- You may freely distribute the URL identifying the publication in the public portal. please follow below link for the End User Agreement:

www.umlib.nl/taverne-license

Take down policy

If you believe that this document breaches copyright please contact us at:

repository@maastrichtuniversity.nl

providing details and we will investigate your claim.
}

Copyright and moral rights for the publications made accessible in the public portal are retained by the authors and/or other copyright owners and it is a condition of accessing publications that users recognise and abide by the legal requirements associated with these

- Users may download and print one copy of any publication from the public portal for the purpose of private study or research.

- You may not further distribute the material or use it for any profit-making activity or commercial gain

If the publication is distributed under the terms of Article $25 \mathrm{fa}$ of the Dutch Copyright Act, indicated by the "Taverne" license above, 


\section{Statistische Bijlage \\ Schoolverlaters tussen onderwijs en arbeidsmarkt 2002}

ROA-R-2003/9B

Researchcentrum voor Onderwijs en Arbeidsmarkt

Faculteit der Economische Wetenschappen en Bedrijfskunde

Universiteit Maastricht

Maastricht, juli 2003 
Niets uit deze uitgave mag worden verveelvoudigd en/of openbaar gemaakt door middel van druk, fotokopie, microfilm, of op welke wijze ook, zonder voorafgaande schriftelijke toestemming van de directeur van het Researchcentrum voor Onderwijs en Arbeidsmarkt. In geval van overname van het datamateriaal moet telkens duidelijk als bron worden vermeld: "Researchcentrum voor Onderwijs en Arbeidsmarkt" of "ROA". Van publicaties waarin gebruik wordt gemaakt van gegevens uit deze Statistische Bijlage ontvangen wij gaarne een exemplaar.

Hoewel de grootst mogelijke zorg is besteed aan de inhoud van dit rapport, kan het ROA in generlei opzicht verantwoordelijkheid op zich nemen voor eventuele onvolledigheden of onjuistheden.

ISBN 90-5321-370-8

Sec03.040.doc 


\section{Inhoud}

Bladzijde

Voorwoord

\section{A. Tabellen per opleidingssector}

\section{Bestemming van schoolverlaters}

A1.1 De uitstroom van schoolverlaters verbijzonderd naar geslacht, etniciteit en gemiddelde leeftijd op moment van enquête

A1.2 Vooropleiding van schoolverlaters

A1.3 Bestemming van schoolverlaters

A1.4 Gevolgde opleiding opnieuw kiezen?

\section{Doorstroom naar vervolgonderwijs}

A2.1 Doorstroom van schoolverlaters naar vervolgonderwijs

A2.2 Belangrijkste opleidingen van schoolverlaters die een vervolgopleiding zijn gaan volgen

A2.3 Oordeel van schoolverlaters over de aansluiting van de afgesloten opleiding met de vervolgopleiding

A2.4 Doorstroom van schoolverlaters naar kenniscentrum beroepsonderwijs bedrijfsleven

3 Intrede op de arbeidsmarkt

A3.1 Werkloosheid en gemiddelde intredewerkloosheid van schoolverlaters die zich aanbieden op de arbeidsmarkt

A3.2 Aard van het dienstverband van werkende schoolverlaters 23

A3.3 Percentage werkende schoolverlaters met een flexibele aanstelling 25

A3.4 Belangrijkste bedrijfsgroepen waarin schoolverlaters werkzaam zijn $\quad 27$

A3.5 Belangrijkste beroepsgroepen waarin schoolverlaters werkzaam zijn 32

A3.6 Grootte van de organisatie waarin schoolverlaters werkzaam zijn 37

A3.7 Beloning van werkende schoolverlaters 39

A3.8 Vereist opleidingsniveau voor de huidige functie volgens de werkgever $\quad 41$

A3.9 Vereiste opleidingsrichting voor de huidige functie volgens de werkgever 42

A3.10 Feitelijke wekelijkse arbeidsduur van werkende schoolverlaters 43

A3.11 Oordeel van de werkende schoolverlaters over de aansluiting tussen de
afgesloten opleiding en de huidige functie

A3.12 Percentage werkende schoolverlaters dat op zoek is naar een andere baan $\quad 46$

\section{Kernindicatoren}

A4.1 Enkele kernindicatoren 


\section{B. Tabellen per opleidingsrichting}

1 Bestemming van schoolverlaters

B1.1 De uitstroom van schoolverlaters verbijzonderd naar geslacht, etniciteit en gemiddelde leeftijd op moment van enquête

B1.2 Vooropleiding van schoolverlaters $\quad 55$

$\begin{array}{lll}\text { B1.3 Bestemming van schoolverlaters } & 60\end{array}$

B1.4 Gevolgde opleiding opnieuw kiezen?

2 Doorstroom naar vervolgonderwijs

B2.1 Doorstroom van schoolverlaters naar vervolgonderwijs 66

B2.2 Belangrijkste opleidingen van schoolverlaters die een vervolgopleiding zijn gaan volgen

B2.3 Oordeel van schoolverlaters over de aansluiting van de afgesloten opleiding met de vervolgopleiding

B2.4 Doorstroom van schoolverlaters naar kenniscentrum beroepsonderwijs bedrijfsleven

3 Intrede op de arbeidsmarkt

B3.1 Werkloosheid en gemiddelde intredewerkloosheid van schoolverlaters die zich aanbieden op de arbeidsmarkt

B3.2 Aard van het dienstverband van werkende schoolverlaters 90

B3.3 Percentage werkende schoolverlaters met een flexibele aanstelling 94

B3.4 Belangrijkste bedrijfsgroepen waarin schoolverlaters werkzaam zijn 96

B3.5 Belangrijkste beroepsgroepen waarin schoolverlaters werkzaam zijn 108

B3.6 Grootte van de organisatie waarin schoolverlaters werkzaam zijn 119

B3.7 Beloning van werkende schoolverlaters 122

B3.8 Vereist opleidingsniveau voor de huidige functie volgens de werkgever 125

B3.9 Vereiste opleidingsrichting voor de huidige functie volgens de werkgever $\quad 127$

B3.10 Feitelijke wekelijkse arbeidsduur van werkende schoolverlaters 130

B3.11 Oordeel van de werkende schoolverlaters over de aansluiting tussen de

$\begin{array}{ll}\text { afgesloten opleiding en de huidige functie } & 133 \\ \text { B3.12 Percentage werkende schoolverlaters dat op zoek is naar een andere baan } & 136\end{array}$

4 Kernindicatoren

B4.1 Enkele kernindicatoren 


\section{Respons}

C.1 Ongewogen aantal respondenten verbijzonderd naar bestemming per opleidingssector

C.2 Naar landelijke populatie gewogen aantal schoolverlaters verbijzonderd naar bestemming per opleidingssector

C.3 Responspercentage per opleidingssector

C.4 Ongewogen aantal respondenten verbijzonderd naar bestemming per opleidingsrichting

C.5 Naar landelijke populatie gewogen aantal schoolverlaters verbijzonderd naar bestemming per opleidingsrichting

C.6 Responspercentage per opleidingsrichting

\section{Opleidingsindeling}

Overzicht van opleidingen per opleidingssector 

Tabellenoverzicht Statistische Bijlage Schoolverlaters tussen Onderwijs en Arbeidsmarkt

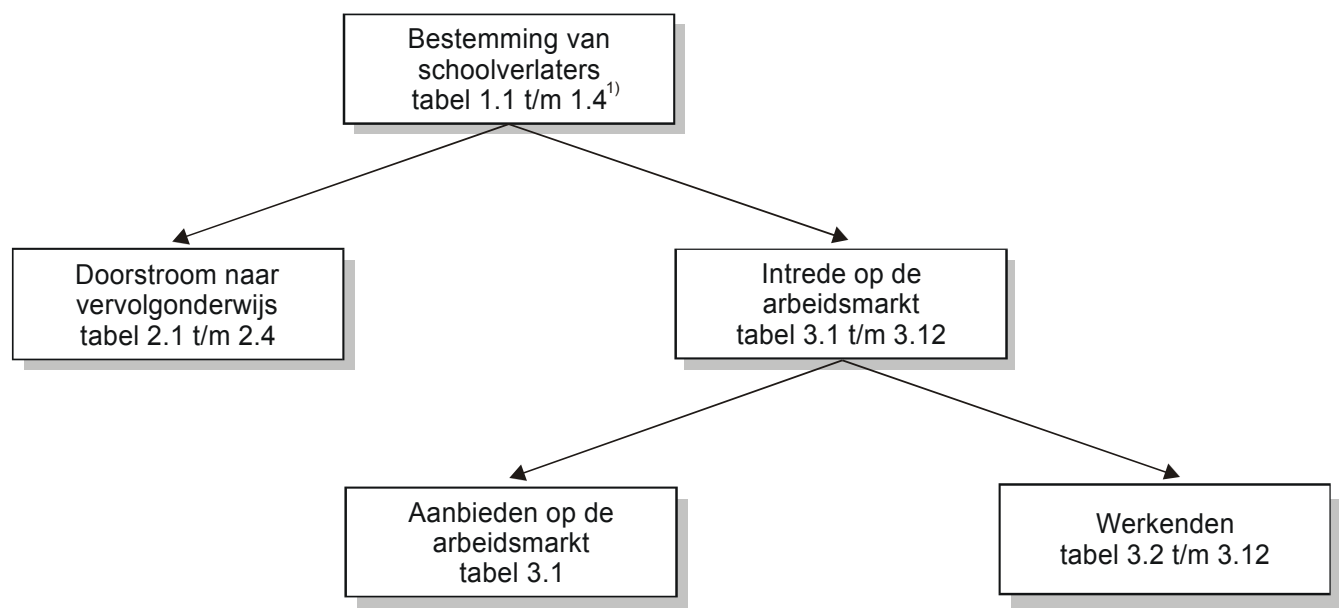

1) Tabelnummers gelden voor het A-deel en het B-deel van de statistische bijlage. Het A-deel bestaat uit tabellen naar opleidingssector, het B-deel uit tabellen naar opleidingsrichting. 



\section{Voorwoord}

In deze Statistische Bijlage bij het rapport Schoolverlaters tussen onderwijs en arbeidsmarkt 2002 wordt een overzicht gegeven van de belangrijkste resultaten van de schoolverlatersonderzoeken die door het Researchcentrum voor Onderwijs en Arbeidsmarkt (ROA) in het najaar van 2002 zijn gehouden onder schoolverlaters en afgestudeerden van het school- of studiejaar 2000/2001. De gegevens bestrijken de volle breedte van het Nederlandse onderwijssysteem en hebben betrekking op de situatie van schoolverlaters en afgestudeerden ongeveer anderhalf jaar na het voltooien van de opleiding. Allereerst betreft het de enquête Registratie van Uitstroom en Bestemming van Schoolverlaters (RUBS). Deze enquête is gericht op schoolverlaters van het algemeen voortgezet onderwijs (AVO), het voorbereidend beroepsonderwijs (VBO) en de beroepsopleidende (BOL) en beroepsbegeleidende leerweg $(\mathrm{BBL})$ van het secundair beroepsonderwijs. Daarnaast zijn gegevens opgenomen afkomstig uit de HBOMonitor en WO-Monitor. Dit zijn volledig vergelijkbare enquêtes gericht op afgestudeerden van het hoger onderwijs en ze worden uitgevoerd onder toezicht van respectievelijk de HBO-Raad en de Vereniging van Samenwerkende Nederlandse Universiteiten (VSNU).

Voor alle getoonde gegevens geldt dat het gaat om gediplomeerde schoolverlaters en afgestudeerden. Bovendien betreft het alleen de uitstroom van voltijdopleidingen. Een uitzondering hierop wordt gevormd door de gediplomeerde schoolverlaters van de BBL die leren en werken combineren.

In deel A worden de belangrijkste gegevens per onderwijssoort en opleidingssector (bijvoorbeeld BOL niveau 1/2 techniek, HBO economie, WO gezondheidszorg) gepresenteerd. Binnen het secundair beroepsonderwijs zijn daarbij de niveaus 1 en 2 (assistent beroepsbeoefenaar (AB) en beginnend beroepsbeoefenaar (BB)) aan de ene kant en de niveaus 3 en 4 (zelfstandig beroepsbeoefenaar (ZB) en (midden)kaderfunctionaris $((\mathrm{M}) \mathrm{KF})$ of specialist) aan de andere kant samengenomen. Deel $B$ geeft vervolgens voor de opleidingsrichtingen van $V B O, B O L$ en $B B L$ een gedetailleerder overzicht. ${ }^{1}$ Daarbij worden alleen voor die opleidingsrichtingen cijfers gepresenteerd waarvoor de resultaten voldoende betrouwbaar worden geacht. Daartoe is een ondergrens van 15 respondenten gehanteerd. Bij tabellen die betrekking hebben op de beroepsbevolking of op werkenden is de ondergrens gesteld op 15 respondenten die tot de beroepsbevolking behoren. Bij tabellen die betrekking hebben op vervolgopleidingen of cursussen is de ondergrens gelegd bij minimaal 15 respondenten die een vervolgopleiding respectievelijk cursus hebben gevolgd. Overigens kunnen de gepresenteerde percentages bij sommige tabellen - vanwege ontbrekende waarnemingen - op een geringer aantal respondenten zijn gebaseerd. Hiermee dient bij de interpretatie van de gegevens rekening te worden gehouden.

Binnen de delen A en B is een onderverdeling gemaakt. Het eerste onderdeel van beide delen heeft betrekking op de bestemming van schoolverlaters: werken, leren of een combinatie van werken en leren via de BBL. Het tweede onderdeel gaat dieper in op degenen die verder leren, terwijl het derde onderdeel de intrede op de arbeidsmarkt nader beschrijft. De groep die werken en leren combineert via de BBL komt zowel in het tweede onderdeel ('doorstroom naar vervolgonderwijs') als in het derde onderdeel ('intrede op de arbeidsmarkt') aan de orde. Ten slotte bevatten de delen $A$ en $B$ een samenvattende tabel met daarin de belangrijkste kernindicatoren.

1. Voor een gedetailleerd beeld van de resultaten voor het HBO wordt verwezen naar het onlangs verschenen Statistisch supplement van de HBO-Monitor 2002, uitgegeven door de HBO-Raad. Uitvoeriger resultaten van de WO-Monitor 2002 zullen later bekend worden gemaakt door de VSNU. 
Deel C geeft enkele achtergrondcijfers van de enquêtes: ongewogen en opgehoogde aantallen schoolverlaters, alsmede de responspercentages. In deel D is tot slot een overzicht opgenomen van de in de enquêtes opgenomen opleidingen per sector. 
A. Tabellen per opleidingssector 



\section{Inhoud}

\section{Bestemming van schoolverlaters}

A1.1 De uitstroom van schoolverlaters verbijzonderd naar geslacht, etniciteit en gemiddelde leeftijd op moment van enquête

A1.2 Vooropleiding van schoolverlaters

A1.3 Bestemming van schoolverlaters

A1.4 Gevolgde opleiding opnieuw kiezen?

\section{Doorstroom naar vervolgonderwijs}

A2.1 Doorstroom van schoolverlaters naar vervolgonderwijs

A2.2 Belangrijkste opleidingen van schoolverlaters die een vervolgopleiding zijn gaan volgen

A2.3 Oordeel van schoolverlaters over de aansluiting van de afgesloten opleiding met de vervolgopleiding

A2.4 Doorstroom van schoolverlaters naar kenniscentrum beroepsonderwijs bedrijfsleven

\section{Intrede op de arbeidsmarkt}

A3.1 Werkloosheid en gemiddelde intredewerkloosheid van schoolverlaters die zich aanbieden op de arbeidsmarkt

A3.2 Aard van het dienstverband van werkende schoolverlaters

A3.3 Percentage werkende schoolverlaters met een flexibele aanstelling

A3.4 Belangrijkste bedrijfsgroepen waarin schoolverlaters werkzaam zijn

A3.5 Belangrijkste beroepsgroepen waarin schoolverlaters werkzaam zijn

A3.6 Grootte van de organisatie waarin schoolverlaters werkzaam zijn

A3.7 Beloning van werkende schoolverlaters

A3.8 Vereist opleidingsniveau voor de huidige functie volgens de werkgever

A3.9 Vereiste opleidingsrichting voor de huidige functie volgens de werkgever

A3.10 Feitelijke wekelijkse arbeidsduur van werkende schoolverlaters

A3.11 Oordeel van de werkende schoolverlaters over de aansluiting tussen de afgesloten opleiding en de huidige functie

A3.12 Percentage werkende schoolverlaters dat op zoek is naar een andere baan

\section{Kernindicatoren}

A4.1 Enkele kernindicatoren 
Tabel A1.1

De uitstroom van schoolverlaters verbijzonderd naar geslacht, etniciteit en gemiddelde leeftijd op moment van enquête

\begin{tabular}{|c|c|c|c|}
\hline Opleidingssector & $\begin{array}{r}\text { vrouw } \\
\%\end{array}$ & $\begin{array}{r}\text { allochtoon } \\
\%\end{array}$ & $\begin{array}{l}\text { leeftijd } \\
\text { gem. }\end{array}$ \\
\hline AVo & 53 & 10 & 18,3 \\
\hline MAVO & 52 & 10 & 17,5 \\
\hline HAVO & 55 & 11 & 18,6 \\
\hline VWO & 52 & 10 & 19,3 \\
\hline VBO & 45 & 8 & 17,5 \\
\hline IVBO & 43 & 9 & 17,8 \\
\hline Landbouw & 54 & 3 & 17,6 \\
\hline Techniek & 5 & 4 & 17,6 \\
\hline Economie & 59 & 22 & 17,4 \\
\hline Gezondheidszorg & 92 & 6 & 17,4 \\
\hline BOL niveau $1 / 2$ & 62 & 19 & 20,3 \\
\hline Landbouw & 43 & 1 & 20,1 \\
\hline Techniek & 7 & 16 & 20,6 \\
\hline Economie & 61 & 24 & 20,4 \\
\hline Gezondheidszorg & 94 & 13 & 20,1 \\
\hline BOL niveau $3 / 4$ & 59 & 6 & 21,6 \\
\hline Landbouw & 42 & 1 & 21,2 \\
\hline Techniek & 16 & 4 & 22,0 \\
\hline Economie & 58 & 11 & 21,4 \\
\hline Gezondheidszorg & 91 & 4 & 21,5 \\
\hline Gedrag en maatschappij & 89 & 5 & 21,7 \\
\hline BBL niveau $1 / 2$ & 29 & 7 & 25,4 \\
\hline Landbouw & 28 & 4 & 27,1 \\
\hline Techniek & 3 & 5 & 23,3 \\
\hline Economie & 49 & 9 & 25,6 \\
\hline Gezondheidszorg & 98 & 11 & 32,3 \\
\hline BBL niveau $3 / 4$ & 49 & 4 & 27,1 \\
\hline Landbouw & 38 & 3 & 25,2 \\
\hline Techniek & 1 & 5 & 25,7 \\
\hline Economie & 43 & 6 & 23,2 \\
\hline Gezondheidszorg & 93 & 3 & 29,6 \\
\hline Gedrag en maatschappij & 81 & 11 & 36,8 \\
\hline HBO & 56 & 7 & 24,7 \\
\hline Landbouw & 38 & 3 & 24,8 \\
\hline Onderwijs & 78 & 4 & 24,7 \\
\hline Techniek & 18 & 6 & 24,7 \\
\hline Economie & 50 & 8 & 24,6 \\
\hline Gezondheidszorg & 84 & 5 & 24,5 \\
\hline Gedrag en maatschappij & 84 & 8 & 24,6 \\
\hline Taal en cultuur & 56 & 8 & 27,0 \\
\hline wo & 55 & 9 & 26,9 \\
\hline Landbouw & 60 & 3 & 25,6 \\
\hline Techniek & 21 & 9 & 26,8 \\
\hline Economie & 33 & 10 & 26,6 \\
\hline Gezondheidszorg & 68 & 10 & 27,3 \\
\hline Gedrag en maatschappij & 74 & 7 & 27,1 \\
\hline Taal en cultuur & 75 & 8 & 27,8 \\
\hline Recht en openbare orde & 61 & 9 & 26,9 \\
\hline Natuurwetenschappen & 47 & 9 & 25,9 \\
\hline
\end{tabular}


Tabel A1.1 (vervolg)

De uitstroom van schoolverlaters verbijzonderd naar geslacht, etniciteit en gemiddelde leeftijd op moment van enquête

\begin{tabular}{lccc}
\hline Opleidingssector & $\begin{array}{r}\text { vrouw } \\
\%\end{array}$ & $\begin{array}{r}\text { allochtoon } \\
\%\end{array}$ & $\begin{array}{r}\text { leeftijd } \\
\text { gem. }\end{array}$ \\
\hline Total & 52 & 9 & 21,3 \\
\hline
\end{tabular}

Toelichting

- Om als allochtoon te worden aangemerkt, dient de schoolverlater of ten minste één van zijn of haar ouders te zijn geboren in één van de landen die worden genoemd in de Wet SAMEN (Stimulering Arbeidsdeelname Minderheden).

- Het betreft de leeftijd per onderzoeksdatum ongeveer anderhalf jaar na schoolverlaten.

- Voor het WO zijn de resultaten met betrekking tot allochtonen gebaseerd op 9 universiteiten. 
Tabel A1.2

Vooropleiding van schoolverlaters

\begin{tabular}{|c|c|c|c|c|c|c|c|c|}
\hline Opleidingssector & $\begin{array}{r}\text { MAVO } \\
\%\end{array}$ & $\begin{array}{r}\text { HAVO } \\
\%\end{array}$ & $\begin{array}{r}\text { VWO } \\
\%\end{array}$ & $\begin{array}{r}\text { VBO } \\
\%\end{array}$ & $\begin{array}{r}\mathrm{BOL} \\
\%\end{array}$ & $\begin{array}{r}\text { BBL } \\
\%\end{array}$ & $\begin{array}{r}\mathrm{HBO} \\
\%\end{array}$ & $\begin{array}{r}\text { overig } \\
\%\end{array}$ \\
\hline BOL niveau $1 / 2$ & 22 & 2 & 0 & 64 & 6 & 1 & 0 & 5 \\
\hline Landbouw & 8 & 1 & 0 & 83 & 1 & 0 & 0 & 6 \\
\hline Techniek & 25 & 0 & 0 & 59 & 9 & 2 & 0 & 4 \\
\hline Economie & 26 & 2 & 0 & 61 & 6 & 2 & 0 & 4 \\
\hline Gezondheidszorg & 14 & 4 & 0 & 71 & 5 & 1 & 0 & 6 \\
\hline BOL niveau $3 / 4$ & 61 & 11 & 1 & 23 & 2 & 0 & 0 & 2 \\
\hline Landbouw & 45 & 7 & 0 & 43 & 1 & 1 & 0 & 2 \\
\hline Techniek & 61 & 15 & 0 & 20 & 2 & 1 & 0 & 1 \\
\hline Economie & 66 & 14 & 0 & 16 & 1 & 0 & 0 & 2 \\
\hline Gezondheidszorg & 55 & 9 & 0 & 31 & 3 & 0 & 0 & 2 \\
\hline Gedrag en maatschappij & 65 & 5 & 1 & 27 & 1 & 0 & 0 & 1 \\
\hline BBL niveau $1 / 2$ & 20 & 3 & 1 & 58 & 3 & 9 & 0 & 6 \\
\hline Landbouw & 24 & 5 & 2 & 46 & 3 & 12 & 0 & 8 \\
\hline Techniek & 17 & 1 & 1 & 68 & 2 & 7 & 0 & 5 \\
\hline Economie & 28 & 4 & 0 & 49 & 3 & 10 & 0 & 6 \\
\hline Gezondheidszorg & 19 & 4 & 3 & 44 & 4 & 12 & 0 & 15 \\
\hline BBL niveau $3 / 4$ & 31 & 9 & 1 & 38 & 2 & 12 & 0 & 7 \\
\hline Landbouw & 35 & 4 & 0 & 37 & 5 & 13 & 0 & 6 \\
\hline Techniek & 19 & 4 & 2 & 50 & 2 & 18 & 0 & 5 \\
\hline Economie & 38 & 9 & 1 & 37 & 1 & 13 & 0 & 2 \\
\hline Gezondheidszorg & 39 & 14 & 1 & 28 & 2 & 7 & 0 & 9 \\
\hline Gedrag en maatschappij & 35 & 7 & 4 & 29 & 0 & 4 & 0 & 21 \\
\hline HBO & 1 & 48 & 27 & 0 & 21 & 1 & 1 & 1 \\
\hline Landbouw & 1 & 48 & 24 & 0 & 24 & 2 & 1 & 1 \\
\hline Onderwijs & 1 & 64 & 18 & 0 & 14 & 1 & 1 & 1 \\
\hline Techniek & 1 & 41 & 27 & 0 & 28 & 1 & 1 & 1 \\
\hline Economie & 0 & 43 & 35 & 0 & 20 & 1 & 0 & 1 \\
\hline
\end{tabular}


Tabel A1.2 (vervolg)

Vooropleiding van schoolverlaters

\begin{tabular}{|c|c|c|c|c|c|c|c|c|}
\hline Opleidingssector & $\begin{array}{r}\text { MAVO } \\
\%\end{array}$ & $\begin{array}{r}\text { HAVO } \\
\%\end{array}$ & $\begin{array}{r}\text { VWO } \\
\%\end{array}$ & $\begin{array}{r}\text { VBO } \\
\%\end{array}$ & $\begin{array}{r}\mathrm{BOL} \\
\%\end{array}$ & $\begin{array}{r}\text { BBL } \\
\%\end{array}$ & $\begin{array}{r}\mathrm{HBO} \\
\%\end{array}$ & $\begin{array}{r}\text { overig } \\
\%\end{array}$ \\
\hline \multicolumn{9}{|l|}{ HBO (vervolg) } \\
\hline Gezondheidszorg & 1 & 55 & 26 & 0 & 15 & 1 & 1 & 1 \\
\hline Gedrag en maatschappij & 1 & 51 & 17 & 0 & 27 & 1 & 1 & 1 \\
\hline Taal en cultuur & 5 & 32 & 41 & 0 & 12 & 1 & 5 & 4 \\
\hline wo & 0 & 1 & 84 & 0 & 0 & 0 & 13 & 1 \\
\hline Landbouw & 0 & 0 & 89 & 0 & 0 & 0 & 10 & 0 \\
\hline Techniek & 0 & 1 & 88 & 0 & 0 & 0 & 10 & 0 \\
\hline Economie & 0 & 1 & 81 & 0 & 0 & 0 & 18 & 1 \\
\hline Gezondheidszorg & 0 & 1 & 90 & 0 & 0 & 0 & 9 & 0 \\
\hline Gedrag en maatschappij & 0 & 2 & 73 & 0 & 1 & 0 & 24 & 1 \\
\hline Taal en cultuur & 0 & 4 & 82 & 0 & 0 & 0 & 13 & 0 \\
\hline Recht en openbare orde & 0 & 2 & 89 & 0 & 0 & 0 & 7 & 1 \\
\hline Natuurwetenschappen & 0 & 0 & 92 & 0 & 0 & 0 & 7 & 0 \\
\hline Totaal & 28 & 18 & 15 & 24 & 7 & 3 & 1 & 3 \\
\hline
\end{tabular}


Tabel A1.3

Bestemming van schoolverlaters

\begin{tabular}{|c|c|c|c|c|c|}
\hline Opleidingssector & $\begin{array}{r}\text { studie } \\
\%\end{array}$ & $\begin{array}{r}\mathrm{BBL} \\
\%\end{array}$ & $\begin{array}{r}\text { betaald werk } \\
\%\end{array}$ & $\begin{array}{r}\text { werkloos } \\
\%\end{array}$ & $\begin{array}{r}\text { anders } \\
\%\end{array}$ \\
\hline $\begin{array}{l}\text { AVO } \\
\text { MAVO } \\
\text { HAVO } \\
\text { VWO }\end{array}$ & $\begin{array}{l}84 \\
77 \\
86 \\
94\end{array}$ & $\begin{array}{l}\mathbf{5} \\
9 \\
2 \\
1\end{array}$ & $\begin{array}{r}8 \\
10 \\
9 \\
3\end{array}$ & $\begin{array}{l}1 \\
1 \\
0 \\
0\end{array}$ & $\begin{array}{l}2 \\
3 \\
1 \\
1\end{array}$ \\
\hline $\begin{array}{l}\text { VBO } \\
\text { IVBO } \\
\text { Landbouw } \\
\text { Techniek } \\
\text { Economie } \\
\text { Gezondheidszorg }\end{array}$ & $\begin{array}{l}\mathbf{5 1} \\
36 \\
56 \\
37 \\
65 \\
64\end{array}$ & $\begin{array}{l}27 \\
23 \\
18 \\
40 \\
17 \\
20\end{array}$ & $\begin{array}{l}\mathbf{1 8} \\
34 \\
22 \\
19 \\
15 \\
12\end{array}$ & $\begin{array}{l}1 \\
3 \\
2 \\
1 \\
1 \\
0\end{array}$ & $\begin{array}{l}3 \\
3 \\
3 \\
3 \\
2 \\
4\end{array}$ \\
\hline $\begin{array}{l}\text { BOL niveau 1/2 } \\
\text { Landbouw } \\
\text { Techniek } \\
\text { Economie } \\
\text { Gezondheidszorg }\end{array}$ & $\begin{array}{l}32 \\
19 \\
21 \\
34 \\
37\end{array}$ & $\begin{array}{r}15 \\
9 \\
27 \\
13 \\
11\end{array}$ & $\begin{array}{l}45 \\
57 \\
47 \\
43 \\
45\end{array}$ & $\begin{array}{l}4 \\
6 \\
4 \\
5 \\
2\end{array}$ & $\begin{array}{l}4 \\
9 \\
1 \\
5 \\
4\end{array}$ \\
\hline $\begin{array}{l}\text { BOL niveau } \mathbf{3 / 4} \\
\text { Landbouw } \\
\text { Techniek } \\
\text { Economie } \\
\text { Gezondheidszorg } \\
\text { Gedrag en maatschappij }\end{array}$ & $\begin{array}{l}42 \\
32 \\
50 \\
46 \\
22 \\
46\end{array}$ & $\begin{array}{l}5 \\
7 \\
2 \\
4 \\
7 \\
6\end{array}$ & $\begin{array}{l}50 \\
56 \\
44 \\
46 \\
68 \\
45\end{array}$ & $\begin{array}{l}2 \\
2 \\
2 \\
2 \\
1 \\
2\end{array}$ & $\begin{array}{l}2 \\
4 \\
1 \\
2 \\
2 \\
2\end{array}$ \\
\hline $\begin{array}{l}\text { BBL niveau 1/2 } \\
\text { Landbouw } \\
\text { Techniek } \\
\text { Economie } \\
\text { Gezondheidszorg }\end{array}$ & $\begin{array}{l}3 \\
2 \\
4 \\
3 \\
1\end{array}$ & $\begin{array}{l}23 \\
20 \\
27 \\
17 \\
18\end{array}$ & $\begin{array}{l}70 \\
74 \\
65 \\
75 \\
78\end{array}$ & $\begin{array}{l}2 \\
1 \\
3 \\
3 \\
1\end{array}$ & $\begin{array}{l}2 \\
2 \\
2 \\
2 \\
2\end{array}$ \\
\hline $\begin{array}{l}\text { BBL niveau } \mathbf{3 / 4} \\
\text { Landbouw } \\
\text { Techniek } \\
\text { Economie } \\
\text { Gezondheidszorg } \\
\text { Gedrag en maatschappij }\end{array}$ & $\begin{array}{r}3 \\
10 \\
3 \\
5 \\
3 \\
3\end{array}$ & $\begin{array}{l}6 \\
5 \\
8 \\
3 \\
6 \\
0\end{array}$ & $\begin{array}{l}88 \\
82 \\
87 \\
89 \\
89 \\
93\end{array}$ & $\begin{array}{l}1 \\
0 \\
1 \\
2 \\
0 \\
1\end{array}$ & $\begin{array}{l}2 \\
3 \\
1 \\
1 \\
2 \\
3\end{array}$ \\
\hline $\begin{array}{l}\text { HBO } \\
\text { Landbouw } \\
\text { Onderwijs } \\
\text { Techniek } \\
\text { Economie } \\
\text { Gezondheidszorg } \\
\text { Gedrag en maatschappij } \\
\text { Taal en cultuur }\end{array}$ & $\begin{array}{r}15 \\
17 \\
9 \\
18 \\
20 \\
10 \\
11 \\
15\end{array}$ & $\begin{array}{l}x \\
x \\
x \\
x \\
x \\
x \\
x \\
x\end{array}$ & $\begin{array}{l}79 \\
76 \\
88 \\
77 \\
74 \\
85 \\
84 \\
68\end{array}$ & $\begin{array}{l}2 \\
2 \\
1 \\
3 \\
2 \\
2 \\
2 \\
5\end{array}$ & $\begin{array}{r}3 \\
4 \\
2 \\
2 \\
3 \\
2 \\
3 \\
12\end{array}$ \\
\hline $\begin{array}{l}\text { WO } \\
\text { Landbouw } \\
\text { Techniek } \\
\text { Economie } \\
\text { Gezondheidszorg } \\
\text { Gedrag en maatschappij } \\
\text { Taal en cultuur } \\
\text { Recht en openbare orde } \\
\text { Natuurwetenschappen }\end{array}$ & $\begin{array}{l}4 \\
3 \\
3 \\
2 \\
5 \\
3 \\
7 \\
2 \\
2 \\
7\end{array}$ & $\begin{array}{l}x \\
x \\
x \\
x \\
x \\
x \\
x \\
x \\
x\end{array}$ & $\begin{array}{l}91 \\
91 \\
92 \\
95 \\
92 \\
90 \\
84 \\
94 \\
88\end{array}$ & $\begin{array}{l}3 \\
5 \\
2 \\
2 \\
1 \\
3 \\
4 \\
2 \\
3\end{array}$ & $\begin{array}{l}3 \\
1 \\
2 \\
1 \\
2 \\
4 \\
5 \\
2 \\
2\end{array}$ \\
\hline Totaal & 46 & 9 & 42 & 1 & 2 \\
\hline
\end{tabular}

$\mathrm{x}=$ antwoordcategorie niet opgenomen 
Tabel A1.4

Gevolgde opleiding opnieuw kiezen?

\begin{tabular}{|c|c|c|c|}
\hline Opleidingssector & $\begin{array}{r}\text { zelfde } \\
\text { opleiding } \\
\%\end{array}$ & $\begin{array}{r}\text { andere } \\
\text { opleiding } \\
\%\end{array}$ & $\begin{array}{r}\text { geen andere } \\
\text { opleiding } \\
\%\end{array}$ \\
\hline BOL niveau $1 / 2$ & 65 & 25 & 10 \\
\hline Landbouw & 64 & 19 & 17 \\
\hline Techniek & 69 & 18 & 13 \\
\hline Economie & 66 & 24 & 9 \\
\hline Gezondheidszorg & 60 & 32 & 8 \\
\hline BOL niveau $3 / 4$ & 77 & 21 & 2 \\
\hline Landbouw & 68 & 26 & 6 \\
\hline Techniek & 83 & 15 & 2 \\
\hline Economie & 72 & 26 & 2 \\
\hline Gezondheidszorg & 74 & 24 & 2 \\
\hline Gedrag en maatschappij & 85 & 13 & 2 \\
\hline BBL niveau $1 / 2$ & 75 & 16 & 10 \\
\hline Landbouw & 67 & 22 & 12 \\
\hline Techniek & 78 & 13 & 9 \\
\hline Economie & 65 & 22 & 12 \\
\hline Gezondheidszorg & 84 & 10 & 6 \\
\hline BBL niveau $3 / 4$ & 80 & 15 & 4 \\
\hline Landbouw & 80 & 14 & 6 \\
\hline Techniek & 83 & 12 & 5 \\
\hline Economie & 70 & 22 & 9 \\
\hline Gezondheidszorg & 83 & 16 & 1 \\
\hline Gedrag en maatschappij & 81 & 18 & 1 \\
\hline HBO & 76 & 23 & 1 \\
\hline Landbouw & 77 & 22 & 1 \\
\hline Onderwijs & 85 & 15 & 0 \\
\hline Techniek & 78 & 22 & 1 \\
\hline Economie & 69 & 30 & 0 \\
\hline Gezondheidszorg & 80 & 20 & 0 \\
\hline Gedrag en maatschappij & 74 & 26 & 0 \\
\hline Taal en cultuur & 86 & 13 & 2 \\
\hline wo & 80 & 20 & 0 \\
\hline Landbouw & 74 & 26 & 0 \\
\hline Techniek & 81 & 19 & 0 \\
\hline Economie & 80 & 20 & 0 \\
\hline Gezondheidszorg & 87 & 13 & 1 \\
\hline Gedrag en maatschappij & 78 & 21 & 0 \\
\hline Taal en cultuur & 72 & 27 & 0 \\
\hline Recht en openbare orde & 85 & 15 & 0 \\
\hline Natuurwetenschappen & 77 & 22 & 0 \\
\hline Totaal & 76 & 20 & 3 \\
\hline
\end{tabular}

Toelichting

- Voor het WO hebben de resultaten betrekking op 10 universiteiten. 
Tabel A2.1

Doorstroom van schoolverlaters naar vervolgonderwijs

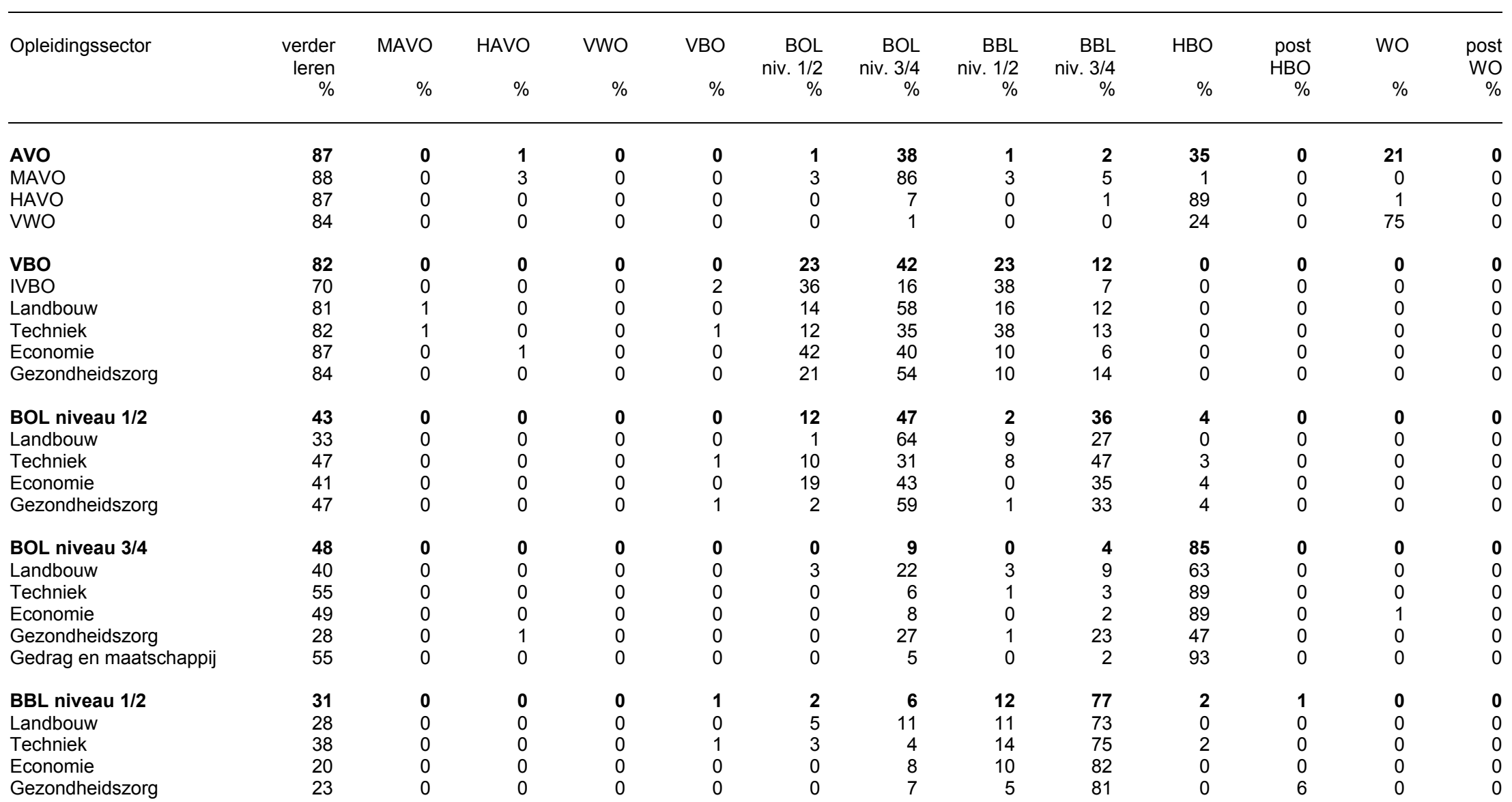


Tabel A2.1 (vervolg)

Doorstroom van schoolverlaters naar vervolgonderwijs

\begin{tabular}{|c|c|c|c|c|c|c|c|c|c|c|c|c|c|}
\hline Opleidingssector & $\begin{array}{r}\text { verder } \\
\text { leren } \\
\%\end{array}$ & $\begin{array}{r}\text { MAVO } \\
\%\end{array}$ & $\begin{array}{r}\text { HAVO } \\
\%\end{array}$ & $\begin{array}{r}\text { VWO } \\
\%\end{array}$ & $\begin{array}{r}\text { VBO } \\
\%\end{array}$ & $\begin{array}{r}\text { BOL } \\
\text { niv. } 1 / 2 \\
\%\end{array}$ & $\begin{array}{r}\text { BOL } \\
\text { niv. } 3 / 4 \\
\%\end{array}$ & $\begin{array}{r}\text { BBL } \\
\text { niv. } 1 / 2 \\
\%\end{array}$ & $\begin{array}{r}\text { BBL } \\
\text { niv. } 3 / 4 \\
\%\end{array}$ & $\begin{array}{r}\text { HBO } \\
\%\end{array}$ & $\begin{array}{r}\text { post } \\
\text { HBO } \\
\%\end{array}$ & $\begin{array}{r}\text { WO } \\
\%\end{array}$ & $\begin{array}{r}\text { post } \\
\text { WO } \\
\%\end{array}$ \\
\hline BBL niveau 3/4 & 16 & 0 & 0 & 0 & 0 & 0 & 10 & 3 & 71 & 16 & 0 & 0 & 0 \\
\hline Landbouw & 25 & 0 & 0 & 0 & 0 & 0 & 52 & 0 & 27 & 21 & 0 & 0 & 0 \\
\hline Techniek & 22 & 0 & 0 & 0 & 0 & 1 & 5 & 3 & 78 & 14 & 0 & 0 & 0 \\
\hline Economie & 9 & 0 & 0 & 0 & 0 & 0 & 1 & 12 & 52 & 35 & 0 & 0 & 0 \\
\hline Gezondheidszorg & 13 & 0 & 0 & 0 & 0 & 0 & 8 & 3 & 76 & 14 & 0 & 0 & 0 \\
\hline Gedrag en maatschappij & 5 & 0 & 0 & 0 & 0 & 0 & 83 & 0 & 0 & 17 & 0 & 0 & 0 \\
\hline HBO & 27 & 0 & 0 & 0 & 0 & 0 & 0 & 0 & 0 & 19 & 1 & 74 & 6 \\
\hline Landbouw & 25 & 0 & 0 & 0 & 0 & 0 & 1 & 0 & 0 & 18 & 1 & 80 & 1 \\
\hline Onderwijs & 24 & 0 & 0 & 0 & 0 & 0 & 1 & 0 & 0 & 49 & 0 & 44 & 6 \\
\hline Techniek & 27 & 0 & 0 & 0 & 0 & 0 & 0 & 0 & 0 & 14 & 0 & 83 & 2 \\
\hline Economie & 32 & 0 & 0 & 0 & 0 & 0 & 0 & 0 & 0 & 8 & 0 & 82 & 10 \\
\hline Gezondheidszorg & 22 & 0 & 0 & 0 & 0 & 0 & 0 & 0 & 0 & 23 & 0 & 70 & 6 \\
\hline Gedrag en maatschappij & 22 & 0 & 0 & 0 & 0 & 0 & 1 & 0 & 0 & 22 & 0 & 75 & 2 \\
\hline Taal en cultuur & 27 & 0 & 0 & 0 & 0 & 1 & 0 & 0 & 0 & 56 & 27 & 16 & 1 \\
\hline wo & 27 & 0 & 0 & 0 & 0 & 0 & 0 & 0 & 0 & 3 & 0 & 20 & 76 \\
\hline Landbouw & 26 & 0 & 0 & 0 & 0 & 0 & 2 & 0 & 0 & 3 & 0 & 12 & 83 \\
\hline Techniek & 18 & 0 & 0 & 0 & 0 & 0 & 0 & 0 & 0 & 3 & 0 & 20 & 77 \\
\hline Economie & 22 & 0 & 0 & 0 & 0 & 0 & 0 & 0 & 0 & 2 & 0 & 19 & 78 \\
\hline Gezondheidszorg & 42 & 0 & 0 & 0 & 0 & 0 & 0 & 0 & 0 & 2 & 0 & 8 & 90 \\
\hline Gedrag en maatschappij & 20 & 0 & 0 & 0 & 0 & 0 & 0 & 0 & 0 & 4 & 0 & 25 & 71 \\
\hline Taal en cultuur & 29 & 0 & 0 & 0 & 0 & 0 & 0 & 0 & 0 & 9 & 0 & 51 & 40 \\
\hline Recht en openbare orde & 27 & 0 & 0 & 0 & 0 & 0 & 0 & 0 & 0 & 1 & 0 & 18 & 80 \\
\hline Natuurwetenschappen & 47 & 0 & 0 & 0 & 0 & 0 & 0 & 0 & 0 & 1 & 0 & 19 & 80 \\
\hline Totaal & 58 & $\mathbf{0}$ & 1 & $\mathbf{0}$ & 0 & 5 & 30 & 5 & 8 & 31 & 0 & 16 & 2 \\
\hline
\end{tabular}


Tabel A2.2

Belangrijkste opleidingen van schoolverlaters die een vervolgopleiding zijn gaan volgen

HAVO

HBO Leraar basisonderwijs

HBO Management, economie en recht

vwo

WO Geneeskunde

WO Nederlands recht

IVBO

BOL BB Helpende (verpleging en verzorging)

VBO landbouw

BOL ZB Sociaal-pedagogisch werk

VBO economie

BOL BB Secretarieel

BOL BB Detailhandel/ambulante handel

BOL BB Bedrijfsadministratie

BOL BB Commercieel administratief medewerker

6

VBO gezondheidszorg

BOL ZB Sociaal-pedagogisch werk

BOL BB Helpende (verpleging en verzorging)

BOL ZB Verzorgende

BOL MKF Sociaal-pedagogisch werker

BBL ZB Verzorgende

$B O L$ niveau 1/2 landbouw

BBL ZB Groene ruimte

BOL niveau $1 / 2$ techniek

BBL ZB Eerste monteur sterkstroominstallaties

BOL niveau $1 / 2$ economie

BBL ZB Zelfstandig werkend kok

BOL MKF Directie-secretaresse/management-assistent

$B O L$ niveau $1 / 2$ gezondheidszorg

BOL ZB Sociaal-pedagogisch werk

BOL ZB Verzorgende

$B B L Z B$ Verzorgende

BBL ZB Verzorgende bij inst. voor gezinsverz.

$B O L$ niveau 3/4 landbouw

HBO Landbouw

HBO Agrarische bedrijfskunde

BOL niveau 3/4 techniek

HBO Bouwkunde

HBO Elektrotechniek

HBO Werktuigbouwkunde

HBO Technische bedrijfskunde

HBO Hogere informatica

BOL niveau 3/4 economie

HBO Commerciele economie 
Tabel A2.2 (vervolg)

Belangrijkste opleidingen van schoolverlaters die een vervolgopleiding zijn gaan volgen

BOL niveau 3/4 gezondheidszorg

BOL MKF Verpleegkundige

HBO Opleiding tot verpleegkundige

BBL MKF Verpleegkundige

BOL niveau 3/4 gedrag en maatschappij

HBO Sociaal pedagogische hulpverlening

HBO Leraar basisonderwijs

HBO Maatschappelijk werk en dienstverlening

HBO Pabo Arnhem

HBO Personeel en arbeid

$B B L$ niveau 1/2 landbouw

BBL ZB Bloemschikken

BBL BB Groene ruimte

BBL ZB Groene ruimte

BBL niveau $1 / 2$ techniek

BBL ZB Voortgezette timmerkracht

BBL ZB Eerste autotechnicus

$B B L$ niveau $1 / 2$ economie

BBL ZB Zelfstandig werkend kok

BBL ZB Zelfstandig werkend gastheer/-vrouw

BBL ZB Eerste verkoper

$B B L$ niveau $1 / 2$ gezondheidszorg

BBL ZB Verzorgende

$B B L$ ZB Verpleging en verzorging

$B B L$ ZB Sociaal-pedagogisch werk

BOL ZB Verzorgende

HBO 2e fase Interieurarchitectuur

BBL niveau 3/4 landbouw

BOL KF Groenvoorziening

BOL MKF Grond-, water- en wegenbouw

HBO Tuin- en landschapsinrichting

$B B L$ niveau 3/4 techniek

BBL ZB Servicemonteur verwarmingstechniek

BBL Specialist Technicus sterkstroominstallaties

BBL MKF Assistent-uitvoerder B\&U

BBL ZB Aankomend projecttechnicus gebouwinstallaties

BBL niveau 3/4 economie

HBO Leraar VO Spaans (2e gr.)

10

HBO Duaal Bedrijfskundige informatica

BBL BB Commercieel

BBL ZB Opticien

BBL ZB Afdelingschef kassa

BBL MKF Assistent-administrateur

BBL niveau 3/4 gezondheidszorg

BBL MKF Verpleegkundige

BBL MKF Verpleging en verzorging

BBL Specialist Verpleging en verzorgende

BBL MKF Gezondheidszorg

HBO Kort Beleid en management gezondheidszorg

BOL MKF Verpleegkundige

BBL Specialist Praktijkopleider (verpleging en verzorgende) 
Tabel A2.2 (vervolg)

Belangrijkste opleidingen van schoolverlaters die een vervolgopleiding zijn gaan volgen

BBL niveau 3/4 gedrag en maatschappij

BOL MKF Sociaal-pedagogisch werker

HBO landbouw

WO Bos- en natuurbeheer

WO Economie van landbouw en milieu

WO Zootechniek

HBO onderwijs

WO Pedagogische wetenschappen

HBO Leraar speciaal onderwijs

WO Onderwijskunde

HBO techniek

WO Bouwkunde

WO Techniek en Maatschappij (nieuw)

WO Bedrijfswetenschappen

HBO economie

WO Bedrijfseconomie

WO Bedrijfswetenschappen

WO Bedrijfskunde

WO Nederlands recht

HBO gezondheidszorg

WO Gezondheidswetenschappen

WO Pedagogische wetenschappen

WO Geneeskunde

WO Bewegingswetenschappen (BW)

HBO gedrag en maatschappij

WO Pedagogische wetenschappen

WO Nederlands recht

WO Psychologie

WO Sociologie

WO Sociaal-culturele wetenschappen

HBO taal en cultuur

HBO 2e Fase Muziek

HBO Uitvoerend musicus

WO landbouw

$\mathrm{AlO} / \mathrm{OIO}$

$\mathrm{AIO} / \mathrm{OIO}$ Natuurwetenschappen

WO techniek

$\mathrm{AIO} / \mathrm{OIO}$

WO economie

Post-doct. beroepsopl. Accountant

$\mathrm{AlO} / \mathrm{OIO}$

Post-doct. beroepsopl. Registeraccountant

WO gezondheidszorg

$\mathrm{AlO} / \mathrm{OIO}$

Post-doct. beroepsopl. Huisarts

WO gedrag en maatschappij 
Tabel A2.2 (vervolg)

Belangrijkste opleidingen van schoolverlaters die een vervolgopleiding zijn gaan volgen

WO taal en cultuur

AIO/OIO

20

WO Kort Onderwijs

WO recht en openbare orde

Post-doct. beroepsopl. Advocatuur

$\mathrm{AlO} / \mathrm{OIO}$

Post-doct. beroepsopl. Kandidaat notaris opleiding

WO natuurwetenschappen

$\mathrm{AIO} / \mathrm{OIO}$

60

WO Geneeskunde

Toelichting

- In de tabel zijn alleen die opleidingen opgenomen die door ten minste 5\% van de schoolverlaters worden gevolgd. 
Tabel A2.3

Oordeel van schoolverlaters over de aansluiting van de afgesloten opleiding met de vervolgopleiding

\begin{tabular}{|c|c|c|c|c|}
\hline Opleidingssector & $\begin{array}{r}\text { goed } \\
\%\end{array}$ & $\begin{array}{r}\text { voldoende } \\
\%\end{array}$ & $\begin{array}{r}\text { matig } \\
\%\end{array}$ & $\begin{array}{r}\text { slecht } \\
\%\end{array}$ \\
\hline AVo & 46 & 39 & 11 & 3 \\
\hline MAVO & 49 & 37 & 10 & 3 \\
\hline HAVO & 37 & 44 & 13 & 4 \\
\hline VWO & 51 & 35 & 11 & 2 \\
\hline VBO & 56 & 31 & 7 & 4 \\
\hline IVBO & 49 & 33 & 9 & 5 \\
\hline Landbouw & 46 & 35 & 11 & 6 \\
\hline Techniek & 57 & 31 & 6 & 4 \\
\hline Economie & 52 & 32 & 8 & 5 \\
\hline Gezondheidszorg & 64 & 29 & 4 & 1 \\
\hline BOL niveau $1 / 2$ & 51 & 35 & 8 & 4 \\
\hline Landbouw & 59 & 26 & 11 & 2 \\
\hline Techniek & 40 & 40 & 12 & 5 \\
\hline Economie & 49 & 37 & 9 & 3 \\
\hline Gezondheidszorg & 59 & 31 & 5 & 5 \\
\hline BOL niveau $3 / 4$ & 37 & 40 & 15 & 7 \\
\hline Landbouw & 40 & 33 & 16 & 6 \\
\hline Techniek & 36 & 40 & 15 & 7 \\
\hline Economie & 32 & 41 & 18 & 9 \\
\hline Gezondheidszorg & 42 & 34 & 15 & 6 \\
\hline Gedrag en maatschappij & 42 & 41 & 11 & 5 \\
\hline BBL niveau $1 / 2$ & 69 & 20 & 7 & 2 \\
\hline Landbouw & 56 & 40 & 2 & 2 \\
\hline Techniek & 71 & 18 & 7 & 2 \\
\hline Economie & 76 & 23 & 1 & 0 \\
\hline Gezondheidszorg & 56 & 16 & 17 & 5 \\
\hline BBL niveau $3 / 4$ & 50 & 36 & 6 & 6 \\
\hline Landbouw & 48 & 41 & 4 & 6 \\
\hline Techniek & 53 & 28 & 5 & 8 \\
\hline Economie & 40 & 38 & 11 & 12 \\
\hline Gezondheidszorg & 48 & 45 & 5 & 0 \\
\hline Gedrag en maatschappij & 91 & 0 & 9 & 0 \\
\hline HBO & 40 & 40 & 12 & 5 \\
\hline Landbouw & 45 & 38 & 11 & 4 \\
\hline Onderwijs & 44 & 37 & 11 & 4 \\
\hline Techniek & 40 & 39 & 12 & 7 \\
\hline Economie & 41 & 42 & 11 & 4 \\
\hline Gezondheidszorg & 42 & 36 & 15 & 4 \\
\hline Gedrag en maatschappij & 30 & 44 & 16 & 7 \\
\hline Taal en cultuur & 47 & 30 & 13 & 6 \\
\hline Totaal & 47 & 37 & 11 & 4 \\
\hline
\end{tabular}

Toelichting

Vraag in de enquête:

- Hoe is de aansluiting tussen de gevolgde [...] opleiding en deze vervolgopleiding? 
Tabel A2.4

Doorstroom van schoolverlaters naar kenniscentrum beroepsonderwijs bedrijfsleven

MAVO

OVDB

ECABO

HTV

KC Handel

VEV/LOB-E

HAVO

ECABO

OVDB

AEQUOR

SOM

INNOVAM

VTenL

HTV

KOC

VWO

Bouwradius

IVBO

OVDB

AEQUOR

KC Handel

HTV

VBO landbouw

AEQUOR

OVDB

ECABO

VBO techniek

VEV/LOB-E

Bouwradius

SOM

HTV

INNOVAM

VTenL

10

VBO economie

ECABO

KC Handel

OVDB

VBO gezondheidszorg

OVDB

KOC

$B O L$ niveau 1/2 landbouw AEQUOR

BOL niveau 1/2 techniek

VEV/LOB-E

INNOVAM

Bouwradius

$\mathrm{SH} \& \mathrm{M}$ 
Tabel A2. 4 (vervolg)

Doorstroom van schoolverlaters naar kenniscentrum beroepsonderwijs bedrijfsleven

BOL niveau $1 / 2$ economie

ECABO

KC Hande

HTV

OVDB

BOL niveau $1 / 2$ gezondheidszorg OVDB

BOL niveau 3/4 landbouw AEQUOR

OVDB

BOL niveau 3/4 techniek

VEV/LOB-E

Intechnium

GOC

VaPro - OVP

INNOVAM

BOL niveau 3/4 economie

ECABO

KC Handel

OVDB

VEV/LOB-E

GOC

VTenL

BOL niveau $3 / 4$ gezondheidszorg

OVDB

In-service Operatie-assistent

BOL niveau 3/4 gedrag en maatschappij

OVDB

ECABO

BBL niveau 1/2 landbouw

AEQUOR

$B B L$ niveau $1 / 2$ techniek

Bouwradius

19

INNOVAM

VEV/LOB-E

Intechnium

SOM

SH\&M

SVS

BBL niveau $1 / 2$ economie

HTV

KC Hande

$B B L$ niveau $1 / 2$ gezondheidszorg

BBL niveau 3/4 landbouw 
Tabel A2. 4 (vervolg)

Doorstroom van schoolverlaters naar kenniscentrum beroepsonderwijs bedrijfsleven

BBL niveau 3/4 techniek

Intechnium

VEV/LOB-E

29

Bouwradius

SOM

BBL niveau 3/4 economie

ECABO

KC Handel

SVGB

OVDB

BBL niveau 3/4 gedrag en maatschappij

OVDB

Toelichting

- In de tabel zijn alleen die kenniscentra opgenomen die door ten minste 5\% van de schoolverlaters worden gevolgd. 
Tabel A3.1

Werkloosheid en gemiddelde intredewerkloosheid van schoolverlaters die zich aanbieden op de arbeidsmarkt

\begin{tabular}{|c|c|c|c|c|c|c|c|c|}
\hline \multirow[t]{2}{*}{ Opleidingssector } & $\begin{array}{r}\text { aanbieden op } \\
\text { arbeidsmarkt }\end{array}$ & werkloosheid & \multicolumn{4}{|c|}{ werkloos tijdens intredeperiode in klassen } & \multirow[b]{2}{*}{$\begin{array}{r}\geq 13 \text { mnd. } \\
\%\end{array}$} & \multirow{2}{*}{$\begin{array}{r}\text { intrede- } \\
\text { werkloosheid } \\
\text { maanden }\end{array}$} \\
\hline & $\%$ & $\%$ & $\begin{array}{r}0 \text { mnd. } \\
\%\end{array}$ & $\begin{array}{r}1-3 \text { mnd. } \\
\%\end{array}$ & $\begin{array}{r}4-6 \text { mnd. } \\
\%\end{array}$ & $\begin{array}{r}7-12 \text { mnd. } \\
\%\end{array}$ & & \\
\hline AVo & 13 & 7 & 89 & 6 & 4 & 0 & 0 & 0,4 \\
\hline MAVO & 20 & 7 & 90 & 6 & 3 & 1 & 0 & 0,4 \\
\hline HAVO & 10 & 8 & 85 & 5 & 9 & 0 & 0 & 0,7 \\
\hline VWO & 5 & 4 & 95 & 5 & 0 & 0 & 0 & 0,2 \\
\hline VBO & 46 & 3 & 93 & 3 & 2 & 1 & 0 & 0,3 \\
\hline IVBO & 61 & 9 & 83 & 9 & 7 & 2 & 0 & 0,7 \\
\hline Landbouw & 41 & 2 & 92 & 5 & 2 & 0 & 1 & 0,3 \\
\hline Techniek & 61 & 2 & 96 & 2 & 0 & 1 & 0 & 0,2 \\
\hline Economie & 31 & 5 & 96 & 2 & 0 & 2 & 0 & 0,2 \\
\hline Gezondheidszorg & 33 & 2 & 89 & 5 & 4 & 2 & 0 & 0,5 \\
\hline BOL niveau $1 / 2$ & 64 & 8 & 83 & 11 & 4 & 1 & 0 & 0,5 \\
\hline Landbouw & 79 & 9 & 79 & 14 & 2 & 1 & 3 & 1,1 \\
\hline Techniek & 76 & 4 & 90 & 5 & 4 & 0 & 0 & 0,3 \\
\hline Economie & 64 & 10 & 83 & 12 & 4 & 1 & 0 & 0,5 \\
\hline Gezondheidszorg & 59 & 8 & 80 & 14 & 6 & 0 & 0 & 0,5 \\
\hline BOL niveau $3 / 4$ & 57 & 4 & 89 & 7 & 2 & 1 & 0 & 0,4 \\
\hline Landbouw & 67 & 3 & 91 & 7 & 1 & 0 & 0 & 0,3 \\
\hline Techniek & 50 & 5 & 87 & 9 & 3 & 1 & 0 & 0,4 \\
\hline Economie & 53 & 5 & 88 & 9 & 2 & 2 & 1 & 0,5 \\
\hline Gezondheidszorg & 78 & 1 & 95 & 3 & 1 & 0 & 0 & 0,2 \\
\hline Gedrag en maatschappij & 53 & 6 & 88 & 6 & 4 & 1 & 0 & 0,4 \\
\hline BBL niveau $1 / 2$ & 95 & 2 & 93 & 4 & 1 & 1 & 1 & 0,3 \\
\hline Landbouw & 94 & 1 & 93 & 6 & 0 & 0 & 0 & 0,3 \\
\hline Techniek & 94 & 2 & 93 & 4 & 1 & 0 & 1 & 0,4 \\
\hline
\end{tabular}


Tabel A3.1 (vervolg)

Werkloosheid en gemiddelde intredewerkloosheid van schoolverlaters die zich aanbieden op de arbeidsmarkt

\begin{tabular}{|c|c|c|c|c|c|c|c|c|}
\hline \multirow[t]{2}{*}{ Opleidingssector } & \multirow{2}{*}{$\begin{array}{r}\text { aanbieden op } \\
\text { arbeidsmarkt } \\
\%\end{array}$} & \multirow{2}{*}{$\begin{array}{r}\text { werkloosheid } \\
\%\end{array}$} & \multicolumn{4}{|c|}{ werkloos tijdens intredeperiode in klassen } & \multirow[b]{2}{*}{$\geq 13$ mnd. } & \multirow{2}{*}{$\begin{array}{r}\text { intrede- } \\
\text { werkloosheid } \\
\text { maanden }\end{array}$} \\
\hline & & & $\begin{array}{r}0 \text { mnd. } \\
\%\end{array}$ & $\begin{array}{r}1-3 \text { mnd. } \\
\%\end{array}$ & $\begin{array}{r}4-6 \text { mnd. } \\
\%\end{array}$ & $\begin{array}{r}7-12 \text { mnd. } \\
\%\end{array}$ & & \\
\hline \multicolumn{9}{|l|}{ BBL niveau $1 / 2$ (vervolg) } \\
\hline Economie & 96 & 4 & 92 & 4 & 2 & 2 & 0 & 0,4 \\
\hline Gezondheidszorg & 98 & 1 & 95 & 4 & 1 & 0 & 0 & 0,1 \\
\hline BBL niveau $3 / 4$ & 96 & 1 & 96 & 2 & 1 & 0 & 0 & 0,1 \\
\hline Landbouw & 92 & 0 & 97 & 2 & 1 & 1 & 0 & 0,2 \\
\hline Techniek & 97 & 1 & 97 & 2 & 0 & 0 & 0 & 0,1 \\
\hline Economie & 95 & 3 & 90 & 7 & 4 & 0 & 0 & 0,3 \\
\hline Gezondheidszorg & 96 & 0 & 99 & 1 & 0 & 1 & 0 & 0,1 \\
\hline Gedrag en maatschappij & 88 & 4 & 93 & 1 & 4 & 1 & 1 & 0,5 \\
\hline HBO & 84 & 3 & 77 & 16 & 5 & 2 & 0 & 0,7 \\
\hline Landbouw & 82 & 4 & 72 & 21 & 5 & 2 & 0 & 0,8 \\
\hline Onderwijs & 90 & 2 & 88 & 9 & 2 & 1 & 0 & 0,4 \\
\hline Techniek & 82 & 3 & 76 & 17 & 5 & 2 & 0 & 0,7 \\
\hline Economie & 81 & 4 & 72 & 19 & 7 & 2 & 0 & 0,9 \\
\hline Gezondheidszorg & 88 & 2 & 86 & 11 & 2 & 0 & 0 & 0,3 \\
\hline Gedrag en maatschappij & 87 & 3 & 75 & 17 & 5 & 2 & 0 & 0,8 \\
\hline Taal en cultuur & 75 & 7 & 65 & 17 & 9 & 9 & 0 & 1,7 \\
\hline wo & 95 & 3 & 68 & 20 & 8 & 3 & 1 & 1,1 \\
\hline Landbouw & 95 & 4 & 62 & 22 & 11 & 5 & 1 & 1,4 \\
\hline Techniek & 97 & 3 & 66 & 21 & 8 & 3 & 1 & 1,3 \\
\hline Economie & 98 & 1 & 69 & 19 & 8 & 3 & 0 & 1,0 \\
\hline Gezondheidszorg & 95 & 1 & 77 & 17 & 4 & 1 & 0 & 0,7 \\
\hline Gedrag en maatschappij & 96 & 4 & 67 & 20 & 8 & 4 & 1 & 1,3 \\
\hline Taal en cultuur & 91 & 5 & 65 & 22 & 8 & 4 & 1 & 1,3 \\
\hline
\end{tabular}


Tabel A3.1 (vervolg)

Werkloosheid en gemiddelde intredewerkloosheid van schoolverlaters die zich aanbieden op de arbeidsmarkt

\begin{tabular}{|c|c|c|c|c|c|c|c|c|}
\hline \multirow[t]{2}{*}{ Opleidingssector } & $\begin{array}{r}\text { aanbieden op } \\
\text { arbeidsmarkt }\end{array}$ & werkloosheid & \multicolumn{4}{|c|}{ werkloos tijdens intredeperiode in klassen } & \multicolumn{2}{|r|}{$\begin{array}{r}\text { intrede } \\
\text { werkloosheid }\end{array}$} \\
\hline & 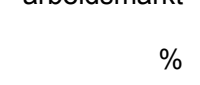 & $\%$ & $\begin{array}{r}0 \text { mnd. } \\
\%\end{array}$ & $\begin{array}{r}1-3 \text { mnd. } \\
\%\end{array}$ & $\begin{array}{r}4-6 \text { mnd. } \\
\%\end{array}$ & $\begin{array}{r}7-12 \text { mnd. } \\
\%\end{array}$ & $\begin{array}{r}\geq 13 \text { mnd. } \\
\%\end{array}$ & maanden \\
\hline \multicolumn{9}{|l|}{ WO (vervolg) } \\
\hline Recht en openbare orde & 97 & 2 & 69 & 19 & 8 & 4 & 0 & 1,1 \\
\hline Natuurwetenschappen & 92 & 2 & 68 & 22 & 6 & 3 & 0 & 1,1 \\
\hline Totaal & 53 & 3 & 86 & 9 & 3 & 1 & 0 & 0,5 \\
\hline
\end{tabular}

Toelichting

- Het werkloosheidspercentage heeft betrekking op de werkloze beroepsbevolking: schoolverlaters zonder werk (of met werk van minder dan 12 uur per week) die actiet zoeken naar werk, minstens 12 uur per week willen werken en daarvoor direct beschikbaar zijn (de laatste twee condities gelden alleen voor HBO en WO). Daarbij is tevens .

- De intredewerkloosheid betreft het aantal maanden dat schoolverlaters zichzelf als werkloos beschouwen. 
Tabel A3.2

Aard van het dienstverband van werkende schoolverlaters

\begin{tabular}{|c|c|c|c|c|c|c|}
\hline Opleidingssector & $\begin{array}{r}\text { leer/werk- } \\
\text { overeenkomst } \\
\%\end{array}$ & $\begin{array}{r}\text { uitzend-, } \\
\text { oproepkracht } \\
\%\end{array}$ & $\begin{array}{r}\text { loondienst } \\
\text { werkgever } \\
\%\end{array}$ & $\begin{array}{r}\text { gesubsidieerde } \\
\text { arbeid (wiw) } \\
\%\end{array}$ & $\begin{array}{r}\text { bedrijf ouders/ } \\
\text { partner } \\
\%\end{array}$ & $\begin{array}{r}\text { eigen bedrijf/ } \\
\text { free-lance } \\
\%\end{array}$ \\
\hline AVo & 32 & 11 & 56 & 0 & 0 & 2 \\
\hline MAVO & 42 & 10 & 48 & 0 & 0 & 1 \\
\hline HAVO & 16 & 16 & 67 & 0 & 0 & 2 \\
\hline VWO & 10 & 5 & 79 & 0 & 0 & 6 \\
\hline VBO & 58 & 3 & 37 & 0 & 0 & 1 \\
\hline IVBO & 34 & 7 & 58 & 0 & 0 & 1 \\
\hline Landbouw & 49 & 4 & 46 & 0 & 1 & 0 \\
\hline Techniek & 63 & 1 & 34 & 0 & 0 & 2 \\
\hline Economie & 60 & 0 & 40 & 0 & 0 & 0 \\
\hline Gezondheidszorg & 61 & 7 & 31 & 0 & 0 & 0 \\
\hline BOL niveau $1 / 2$ & 23 & 5 & 72 & 0 & 0 & 1 \\
\hline Landbouw & 6 & 6 & 84 & 1 & 1 & 1 \\
\hline Techniek & 32 & 3 & 64 & 0 & 0 & 0 \\
\hline Economie & 22 & 5 & 73 & 0 & 0 & 0 \\
\hline Gezondheidszorg & 21 & 5 & 73 & 0 & 0 & 1 \\
\hline BOL niveau $3 / 4$ & 5 & 5 & 89 & 0 & 0 & 1 \\
\hline Landbouw & 7 & 5 & 81 & 0 & 5 & 2 \\
\hline Techniek & 2 & 5 & 91 & 0 & 0 & 2 \\
\hline Economie & 4 & 7 & 89 & 0 & 0 & 0 \\
\hline Gezondheidszorg & 9 & 1 & 89 & 0 & 0 & 1 \\
\hline Gedrag en maatschappij & 3 & 6 & 90 & 0 & 0 & 0 \\
\hline BBL niveau $1 / 2$ & 23 & 2 & 74 & 0 & 0 & 1 \\
\hline Landbouw & 18 & 3 & 73 & 5 & 0 & 0 \\
\hline Techniek & 28 & 2 & 69 & 0 & 0 & 1 \\
\hline Economie & 19 & 1 & 79 & 0 & 0 & 1 \\
\hline Gezondheidszorg & 14 & 1 & 84 & 0 & 0 & 0 \\
\hline
\end{tabular}


Tabel A3.2 (vervolg)

Aard van het dienstverband van werkende schoolverlaters

\begin{tabular}{|c|c|c|c|c|c|c|}
\hline Opleidingssector & $\begin{array}{r}\text { leer/werk- } \\
\text { overeenkomst } \\
\%\end{array}$ & $\begin{array}{r}\text { uitzend-, } \\
\text { oproepkracht } \\
\%\end{array}$ & $\begin{array}{r}\text { loondienst } \\
\text { werkgever } \\
\%\end{array}$ & $\begin{array}{r}\text { gesubsidieerde } \\
\text { arbeid (wiw) } \\
\%\end{array}$ & $\begin{array}{r}\text { bedrijf ouders/ } \\
\text { partner } \\
\%\end{array}$ & $\begin{array}{r}\text { eigen bedrijf/ } \\
\text { free-lance } \\
\%\end{array}$ \\
\hline BBL niveau $3 / 4$ & 5 & 1 & 94 & 0 & 0 & 0 \\
\hline Landbouw & 1 & 0 & 93 & 2 & 1 & 2 \\
\hline Techniek & 7 & 0 & 93 & 0 & 0 & 0 \\
\hline Economie & 2 & 2 & 96 & 0 & 0 & 1 \\
\hline Gezondheidszorg & 4 & 0 & 95 & 0 & 0 & 0 \\
\hline Gedrag en maatschappij & 0 & 2 & 98 & 0 & 0 & 0 \\
\hline HBO & 0 & 6 & 91 & $\mathbf{0}$ & 0 & 2 \\
\hline Landbouw & 0 & 9 & 85 & 0 & 2 & 5 \\
\hline Onderwijs & 0 & 3 & 96 & 0 & 0 & 0 \\
\hline Techniek & 0 & 6 & 92 & 0 & 0 & 2 \\
\hline Economie & 0 & 7 & 90 & 0 & 0 & 2 \\
\hline Gezondheidszorg & 0 & 5 & 94 & 0 & 0 & 1 \\
\hline Gedrag en maatschappij & 0 & 9 & 90 & 0 & 0 & 1 \\
\hline Taal en cultuur & 0 & 7 & 63 & 0 & 0 & 30 \\
\hline wo & 0 & 4 & 93 & 0 & 0 & 3 \\
\hline Landbouw & 0 & 8 & 91 & 0 & 0 & 1 \\
\hline Techniek & 0 & 2 & 95 & 0 & 0 & 3 \\
\hline Economie & 0 & 2 & 95 & 0 & 0 & 2 \\
\hline Gezondheidszorg & 0 & 1 & 95 & 0 & 0 & 4 \\
\hline Gedrag en maatschappij & 0 & 7 & 92 & 0 & 0 & 2 \\
\hline Taal en cultuur & 0 & 9 & 86 & 0 & 0 & 5 \\
\hline Recht en openbare orde & 0 & 2 & 96 & 0 & 0 & 2 \\
\hline Natuurwetenschappen & 0 & 5 & 94 & 0 & 0 & 1 \\
\hline Totaal & 14 & 4 & 80 & 0 & 0 & 1 \\
\hline
\end{tabular}


Tabel A3.3

Percentage werkende schoolverlaters met een flexibele aanstelling

Opleidingssector

AVo

MAVO

HAVO

VWO

VBO

IVBO

Landbouw

Techniek

Economie

Gezondheidszorg

BOL niveau $1 / 2$

Landbouw

Techniek

Economie

Gezondheidszorg

BOL niveau 3/4

Landbouw

Techniek

Economie

Gezondheidszorg

Gedrag en maatschappij

BBL niveau 1/2

Landbouw

Techniek

Economie

Gezondheidszorg

BBL niveau 3/4

Landbouw

Techniek

Economie

Gezondheidszorg

Gedrag en maatschappij

HBO

Landbouw

Onderwijs

Techniek

Economie

Gezondheidszorg

Gedrag en maatschappij

Taal en cultuur

WO

Landbouw

Techniek

Economie

Gezondheidszorg

Gedrag en maatschappij

Taal en cultuur 
Tabel A3.3 (vervolg)

Percentage werkende schoolverlaters met een flexibele aanstelling

Opleidingssector

WO (vervolg)

Recht en openbare orde

Natuurwetenschappen

Totaal

Toelichting

- Voor het WO hebben de resultaten betrekking op 13 universiteiten.

- Een flexibele aanstelling betreft een aanstelling als uitzendkracht, oproepkracht e.d. of een aanstelling in tijdelijke dienst (met een contract korter dan één jaar (alleen voor HBO en WO)). 
Tabel A3.4

Belangrijkste bedrijfsgroepen waarin schoolverlaters werkzaam zijn

MAVO

Ov. gespec. detailh. in winkel

Overheidsdienst.

Gezondheidszorg

Restaurants/cafetaria's/snackbars ed

Ov. dienstverlening

HAVO

Niet-gespec. detailh. in winkel

Overheidsdienst.

Hotels/pensions/conferentie-oorden

Gezondheidszorg

VWO

Overheidsdienst.

Gezondheidszorg

Rechtsk. dienstverl./account./belastingconsul./holdings ed

Prod./distrib. elektriciteit/aardgas/stoom/warm water

Grooth. voedings-/genotmid.

Radio/tv

Overig amusement/kunst

IVBO

Burgerl./utilit.;grond-/water-/wegenb. (excl. grondverz.)

Ov. gespec. detailh. in winkel

Welzijnszorg

Niet-gespec. detailh. in winkel

Dienstverl. tbv landb. (excl. veterin.dienst.)

Akker-/tuinbouw

VBO landbouw

Ov. gespec. detailh. in winkel

Niet-gespec. detailh. in winkel

Overheidsdienst.

Welzijnszorg

Ov. dienstverlening

VBO techniek

Afwerken gebouwen

Bouwinstallatie

Restaurants/cafetaria's/snackbars ed

Burgerl./utilit.;grond-/water-/wegenb. (excl. grondverz.)

VBO economie

Ov. gespec. detailh. in winkel

Niet-gespec. detailh. in winkel

Restaurants/cafetaria's/snackbars ed

Rechtsk. dienstverl./account./belastingconsul./holdings ed

VBO gezondheidszorg

Welzijnszorg

Ov. dienstverlening

Niet-gespec. detailh. in winkel

Ov. gespec. detailh. in winkel

Hotels/pensions/conferentie-oorden 
BOL niveau 1/2 landbouw

Ov. gespec. detailh. in winkel

Dienstverl. tbv landb. (excl. veterin.dienst.)

Grooth. landbouwprod./lev. dieren

Sport

Detailh. farmac./med. art./parfum/cosmet. in winkel

BOL niveau $1 / 2$ techniek

Bouwinstallatie

Handel in/repar. auto's (1)

Burgerl./utilit.;grond-/water-/wegenb. (excl. grondverz.)

Bouwnijverheid

Ov. gespec. detailh. in winkel

BOL niveau $1 / 2$ economie

Ov. gespec. detailh. in winkel

Restaurants/cafetaria's/snackbars ed

Overheidsdienst.

Hotels/pensions/conferentie-oorden

BOL niveau $1 / 2$ gezondheidszorg

Welzijnszorg

Ov. dienstverlening

Gezondheidszorg

Restaurants/cafetaria's/snackbars ed

BOL niveau 3/4 landbouw

Ov. gespec. detailh. in winkel

Dienstverl. tbv landb. (excl. veterin.dienst.)

Akker-/tuinbouw

Fokken/houden dieren

BOL niveau 3/4 techniek

Burgerl./utilit.;grond-/water-/wegenb. (excl. grondverz.)

Bouwinstallatie

Architecten-/ingenieurs-/ov. techn.ontw.-/teken-/adviesbur.

Ov. gespec. detailh. in winkel

BOL niveau 3/4 economie

Ov. gespec. detailh. in winkel

Rechtsk. dienstverl./account./belastingconsul./holdings ed Hotels/pensions/conferentie-oorden

Reisorgan./-bemid.;informatieverstrek. op gebied toerisme

BOL niveau $3 / 4$ gezondheidszorg

Gezondheidszorg

Welzijnszorg

Ov. dienstverlening

Detailh. farmac./med. art./parfum/cosmet. in winkel

BOL niveau $3 / 4$ gedrag en maatschappij

BBL niveau 1/2 landbouw

Dienstverl. tbv landb. (excl. veterin.dienst.) 42

Ov. gespec. detailh. in winkel

Akker-/tuinbouw

Grooth. voedings-/genotmid. 
BBL niveau $1 / 2$ techniek

Burgerl./utilit.;grond-/water-/wegenb. (excl. grondverz.)

Bouwinstallatie

Handel in/repar. auto's (1)

Afwerken gebouwen

BBL niveau $1 / 2$ economie

Restaurants/cafetaria's/snackbars ed $\quad 14$

Beveiliging/opsporing $\quad 14$

Ov. gespec. detailh. in winkel 12

Hotels/pensions/conferentie-oorden $\quad 12$

Niet-gespec. detailh. in winkel 11

BBL niveau $1 / 2$ gezondheidszorg

Welzijnszorg

Ov. dienstverlening

Gezondheidszorg 18

BBL niveau 3/4 landbouw

Dienstverl. tbv landb. (excl. veterin.dienst.)

Ov. gespec. detailh. in winkel $\quad 32$

Akker-/tuinbouw $r$

Openbaar bestuur $\quad 6$

BBL niveau 3/4 techniek

Bouwinstallatie

Handel in/repar. auto's (1)

BBL niveau 3/4 economie

Ov. gespec. detailh. in winkel

Restaurants/cafetaria's/snackbars ed

Hotels/pensions/conferentie-oorden

Niet-gespec. detailh. in winke

BBL niveau 3/4 gezondheidszorg

Welzijnszorg

Gezondheidszorg

Ov. dienstverlening

Gezondheids-/welzijnszorg

BBL niveau 3/4 gedrag en maatschappij

Gezondheidszorg

Gezondheids-/welzijnszorg

HBO landbouw

Openbaar bestuur

Rechtsk. dienstverl./account./belastingconsul./holdings ed

HBO onderwijs

Basisonderwijs voor leerplichtingen/speciaal onderwijs

Voortgezet onderwijs

HBO techniek

Architecten-/ingenieurs-/ov. techn.ontw.-/teken-/adviesbur.

Burgerl./utilit.;grond-/water-/wegenb. (excl. grondverz.)

Adviesbur. op gebied automat./systeemh. 
HBO economie

Rechtsk. dienstverl./account./belastingconsul./holdings ed

HBO gezondheidszorg

Gezondheidszorg

HBO gedrag en maatschappij

Welzijnszorg

Gezondheidszorg

Uitzendbur./uitleenbedr./arbeidsbemid./testen/werven/select.

HBO taal en cultuur

Overig amusement/kunst

Reklamebureaus ed

Activ. op gebied film/video

WO landbouw

Hoger onderwijs

Architecten-/ingenieurs-/ov. techn.ontw.-/teken-/adviesbur. Natuurwet. speur-/ontwikkelingsw.

Openbaar bestuur

Gezondheidszorg

Maatschappij-/geesteswet. speur-/ontwikkelingsw.

Rechtsk. dienstverl./account./belastingconsul./holdings ed

\section{WO techniek}

Architecten-/ingenieurs-/ov. techn.ontw.-/teken-/adviesbur. Hoger onderwijs

Adviesbur. op gebied automat./systeemh.

WO economie

Rechtsk. dienstverl./account./belastingconsul./holdings ed

WO gezondheidszorg

Gezondheidszorg

Hoger onderwijs

Welzijnszorg

WO gedrag en maatschappij

Gezondheidszorg

Openbaar bestuur

Welzijnszorg

Hoger onderwijs

Rechtsk. dienstverl./account./belastingconsul./holdings ed

Overheidsdienst.

WO taal en cultuur

Hoger onderwijs

Openbaar bestuur

Uitgeverijen

WO recht en openbare orde

Rechtsk. dienstverl./account./belastingconsul./holdings ed 
Tabel A3.4 (vervolg)

Belangrijkste bedrijfsgroepen waarin schoolverlaters werkzaam zijn

WO recht en openbare orde (vervolg)

Openbaar bestuur

WO natuurwetenschappen

Hoger onderwijs

Detailh. farmac./med. art./parfum/cosmet. in winkel

Architecten-/ingenieurs-/ov. techn.ontw.-/teken-/adviesbur.

Natuurwet. speur-/ontwikkelingsw.

\section{Toelichting}

- De bedrijven waarin de schoolverlaters werkzaam zijn, zijn geclassificeerd volgens de Standaard Bedrijfs Indeling van het CBS. Op het hier gepresenteerde niveau van bedrijfsgroepen worden in totaal 211 categorieën onderscheiden.

- In de tabel zijn alleen die bedrijfsgroepen weergegeven waarin ten minste $5 \%$ van de schoolverlaters werkzaam is. 
Tabel A3.5

Belangrijkste beroepsgroepen waarin schoolverlaters werkzaam zijn

MAVO

Hulpkrachten horeca en verzorging

Verkopers

Aspirant politieagenten, soldaten en beveiligingshulpkrachte

Assembleurs

Receptionisten en administratieve employés

HAVO

Verkopers

Boekhouders en secretaresses

Aspirant politieagenten, soldaten en beveiligingshulpkrachte

Chauffeurs

Verpleeghulpen en leerling-verpleegkundigen

Commercieel employés

VWO

Verkopers

Receptionisten en administratieve employés

Aspirant politieagenten, soldaten en beveiligingshulpkrachte

Hulpkrachten horeca en verzorging

Boekhouders en secretaresses

Elektromonteurs

Verplegenden en doktersassistenten

Politieagenten, onderofficieren en beveiligingsemployés

Bibliotheekassistenten

\section{IVBO}

Agrarische arbeider

Verkopers

Bouwvakkers

Hulpkrachten horeca en verzorging

Productiemedewerker

Laders en lossers

VBO landbouw

Verkopers

Agrarische arbeider

Hulpkrachten horeca en verzorging

Verzorgend personeel

Aspirant politieagenten, soldaten en beveiligingshulpkrachte

\section{VBO techniek}

Bouwvakkers

Monteurs

Hulpkrachten horeca en verzorging

Aannemers en installateurs

Elektromonteurs

Assembleurs

VBO economie

Verkopers

Receptionisten en administratieve employés

\section{VBO gezondheidszorg}

Hulpkrachten horeca en verzorging 
VBO gezondheidszorg (vervolg)

Verpleeghulpen en leerling-verpleegkundigen

BOL niveau 1/2 landbouw

Agrarische arbeider

Verkopers

Landbouwmachinebestuurders en vissers

BOL niveau $1 / 2$ techniek

Monteurs

Bouwvakkers

16

Aannemers en installateurs

Elektromonteurs

Monteurs en controleurs elektrotechnische producten

BOL niveau $1 / 2$ economie

Receptionisten en administratieve employés

Verkopers

Hulpkrachten horeca en verzorging

Boekhouders en secretaresses

Aspirant politieagenten, soldaten en beveiligingshulpkrachte

Verzorgend personeel

BOL niveau $1 / 2$ gezondheidszorg

Verzorgend personeel

Hulpkrachten horeca en verzorging

Verkopers

Receptionisten en administratieve employés

Interieurverzorger

BOL niveau 3/4 landbouw

Agrarische arbeider

Verkopers

Agrarische bedrijfshoofden

Bouwvakkers

BOL niveau 3/4 techniek

Aannemers en installateurs

Monteurs

Elektromonteurs

BOL niveau 3/4 economie

Boekhouders en secretaresses $\quad 22$

Commercieel employés $\quad 16$

Receptionisten en administratieve employés $\quad 15$

$\begin{array}{ll}\text { Verkopers } & 7\end{array}$

Winkeliers

BOL niveau $3 / 4$ gezondheidszorg

Verplegenden en doktersassistenten $\quad 34$

$\begin{array}{lr}\text { Verzorgend personeel } & 29\end{array}$

$\begin{array}{lr}\text { Apothekersassistenten en medisch laboranten } & 8\end{array}$

BOL niveau 3/4 gedrag en maatschappij

Verzorgend personeel

Activiteitenbegeleiders en medewerkers arbeidsbemiddeling

Hulpkrachten horeca en verzorging

Therapeuten en verpleegkundigen 
BBL niveau 1/2 landbouw

Agrarische arbeider

Bouwvakkers

Verkopers

Agrarische vakkrachten

$B B L$ niveau $1 / 2$ techniek

Aannemers en installateurs

Bouwvakkers

Monteurs

Assembleurs

Chauffeurs

Elektromonteurs

BBL niveau $1 / 2$ economie

Hulpkrachten horeca en verzorging

Verkopers

Aspirant politieagenten, soldaten en beveiligingshulpkrachte

Kantoorhulpen, inpakkers en colporteurs

Verzorgend personeel

BBL niveau $1 / 2$ gezondheidszorg

Verzorgend personeel

Hulpkrachten horeca en verzorging

Verpleeghulpen en leerling-verpleegkundigen

BBL niveau 3/4 landbouw

Agrarische arbeider

Verkopers

Bouwvakkers

Agrarische vakkrachten

BBL niveau 3/4 techniek

Aannemers en installateurs

Monteurs

Bouwvakkers

10

Elektromonteurs

BBL niveau 3/4 economie

Verzorgend personeel

Verkopers

Winkeliers

Hulpkrachten horeca en verzorging

Receptionisten en administratieve employés

BBL niveau $3 / 4$ gezondheidszorg

Verzorgend personeel

Verplegenden en doktersassistenten

Ziekenverzorgenden

BBL niveau 3/4 gedrag en maatschappij

Activiteitenbegeleiders en medewerkers arbeidsbemiddeling

Verzorgend personeel

Hulpkrachten horeca en verzorging

HBO landbouw

Milieuhygienisten en agrarisch vertegenwoordigers

Organisatie-adviseurs

Assistent accountants 
HBO landbouw (vervolg)

Agrarische bedrijfshoofden

HBO onderwijs

Leraar basisonderwijs

Docenten talen en expressie

Docenten sociale vakken (2e en $3 e$ gr.)

HBO techniek

Systeemanalisten

Architecten en bouwkundig projectleiders

We rktuigbouwkundig ontwerpers en hoofden technische dienst

Technisch systeemanalisten

Technisch analisten

HBO economie

Commercieel medewerkers

Assistent accountants

Commercieel employés

Systeemanalisten

HBO gezondheidszorg

Therapeuten en verpleegkundigen

HBO gedrag en maatschappij

Sociaal-cultureel werkers

Activiteitenbegeleiders en medewerkers arbeidsbemiddeling

Verzorgend personeel

HBO taal en cultuu

Kunstenaars

WO landbouw

Natuurwetenschappers

17

Landbouwkundigen

Artsen

Milieuhygienisten en agrarisch vertegenwoordigers

\section{WO techniek}

Weg- en waterbouwkundigen

Materiaalkundigen

Werktuigbouwkundigen

Elektrotechnici

Organisatiedeskundigen

Architecten en bouwkundig projectleiders

Systeemanalisten

WO economie

Commercieel medewerkers $\quad 19$

Assistent accountants

Organisatiedeskundigen

Accountants

Juristen

WO gezondheidszorg

Artsen 
Tabel A3.5 (vervolg)

Belangrijkste beroepsgroepen waarin schoolverlaters werkzaam zijn

WO gedrag en maatschappij

Sociaal-wetenschappelijk onderzoekers $\quad 24$

Sociaal-cultureel werkers

Onderwijskundigen en pedagogen

WO taal en cultuur

Commercieel medewerkers

Taalkundigen

Journalisten

Docenten letteren (1e gr. en WO)

9

Boekhouders en secretaresses

wo recht en openbare orde

Juristen

WO natuurwetenschappen

Natuurwetenschappers

Systeemanalisten

Artsen

\section{Toelichting}

- De beroepen waarin de schoolverlaters werkzaam zijn, zijn geclassificeerd volgens de Standaard Beroepenclassificatie 1992 van het CBS. Binnen de elementaire beroepen is hierbij door het ROA een nader onderscheid gemaakt. Bovendien zijn de namen van de beroepen verduidelijkt. Op het hier gepresenteerde niveau van beroepsgroepen worden in totaal 127 categorieën onderscheiden.

- In de tabel zijn alleen die beroepsgroepen weergegeven waarin ten minste 5\% van de schoolverlaters werkzaam is. 
Tabel A3.6

Grootte van de organisatie waarin schoolverlaters werkzaam zijn

\begin{tabular}{|c|c|c|c|c|c|}
\hline Opleidingssector & $\begin{array}{r}1 \text { pers } \\
\%\end{array}$ & $\begin{array}{r}2 \mathrm{t} / \mathrm{m} 9 \\
\text { pers } \\
\%\end{array}$ & $\begin{array}{r}10 \mathrm{t} / \mathrm{m} 49 \\
\text { pers } \\
\%\end{array}$ & $\begin{array}{r}50 \mathrm{t} / \mathrm{m} 99 \\
\text { pers } \\
\%\end{array}$ & $\begin{array}{r}\geq 100 \\
\text { pers } \\
\%\end{array}$ \\
\hline AVo & 1 & 19 & 29 & 10 & 41 \\
\hline MAVO & 2 & 18 & 32 & 7 & 41 \\
\hline HAVO & & 20 & 20 & 17 & 44 \\
\hline VWO & & 25 & 35 & 9 & 31 \\
\hline VBO & 1 & 28 & 36 & 8 & 27 \\
\hline IVBO & & 35 & 37 & 11 & 17 \\
\hline Landbouw & 2 & 29 & 31 & 8 & 30 \\
\hline Techniek & 1 & 28 & 38 & 9 & 24 \\
\hline Economie & 3 & 28 & 46 & 7 & 16 \\
\hline Gezondheidszorg & & 25 & 24 & 6 & 45 \\
\hline BOL niveau $1 / 2$ & 2 & 20 & 29 & 6 & 43 \\
\hline Landbouw & 1 & 40 & 40 & 6 & 13 \\
\hline Techniek & & 31 & 35 & 12 & 22 \\
\hline Economie & & 18 & 33 & 3 & 46 \\
\hline Gezondheidszorg & 6 & 16 & 15 & 8 & 55 \\
\hline BOL niveau $3 / 4$ & 1 & 16 & 25 & 10 & 49 \\
\hline Landbouw & 5 & 39 & 26 & 9 & 22 \\
\hline Techniek & 2 & 16 & 28 & 8 & 46 \\
\hline Economie & 0 & 13 & 29 & 11 & 47 \\
\hline Gezondheidszorg & 2 & 17 & 17 & 7 & 57 \\
\hline Gedrag en maatschappij & 0 & 7 & 22 & 13 & 57 \\
\hline BBL niveau $1 / 2$ & 0 & 19 & 32 & 12 & 36 \\
\hline Landbouw & 1 & 29 & 29 & 3 & 38 \\
\hline Techniek & 0 & 20 & 36 & 12 & 31 \\
\hline Economie & & 15 & 36 & 18 & 31 \\
\hline Gezondheidszorg & & 18 & 13 & 10 & 58 \\
\hline BBL niveau $3 / 4$ & 0 & 12 & 24 & 9 & 55 \\
\hline Landbouw & 2 & 39 & 30 & 7 & 23 \\
\hline Techniek & 0 & 9 & 39 & 12 & 39 \\
\hline Economie & & 17 & 40 & 12 & 31 \\
\hline Gezondheidszorg & & 8 & 5 & 6 & 81 \\
\hline Gedrag en maatschappij & & 2 & 19 & 7 & 71 \\
\hline HBO & 1 & 8 & 22 & 9 & 60 \\
\hline Landbouw & 1 & 12 & 18 & 7 & 63 \\
\hline Onderwijs & 0 & 5 & 52 & 10 & 32 \\
\hline Techniek & 1 & 9 & 17 & 10 & 64 \\
\hline Economie & 1 & 7 & 16 & 10 & 66 \\
\hline Gezondheidszorg & 1 & 18 & 10 & 3 & 68 \\
\hline Gedrag en maatschappij & 0 & 3 & 12 & 8 & 76 \\
\hline Taal en cultuur & 12 & 20 & 28 & 13 & 27 \\
\hline wo & 1 & 7 & 13 & 7 & 72 \\
\hline Landbouw & 0 & 5 & 12 & 5 & 77 \\
\hline Techniek & 1 & 7 & 14 & 5 & 74 \\
\hline Economie & 0 & 5 & 8 & 6 & 81 \\
\hline Gezondheidszorg & 0 & 10 & 8 & 3 & 79 \\
\hline Gedrag en maatschappij & 1 & 6 & 14 & 9 & 70 \\
\hline Taal en cultuur & 3 & 10 & 21 & 12 & 55 \\
\hline
\end{tabular}


Tabel A3.6 (vervolg)

Grootte van de organisatie waarin schoolverlaters werkzaam zijn

\begin{tabular}{lrrrrr}
\hline Opleidingssector & 1 pers & $\begin{array}{r}2 \mathrm{t} / \mathrm{m} 9 \\
\text { pers } \\
\%\end{array}$ & $\begin{array}{r}10 \mathrm{t} / \mathrm{m} \text { 49 } \\
\text { pers } \\
\%\end{array}$ & $\begin{array}{r}50 \mathrm{t} / \mathrm{m} \text { 99 } \\
\text { pers } \\
\%\end{array}$ & $\begin{array}{r}\geq 100 \\
\text { pers } \\
\%\end{array}$ \\
\hline Wo (vervolg) & $\%$ & & & & \\
$\begin{array}{l}\text { Recht en openbare orde } \\
\text { Natuurwetenschappen }\end{array}$ & 0 & 5 & 17 & 9 & 69 \\
Totaal & 0 & 6 & 16 & 7 & $\mathbf{4 9}$ \\
\hline
\end{tabular}

\section{Toelichting}

- Voor het WO hebben de resultaten betrekking op 10 universiteiten.

Vraag in de enquête:

- Hoeveel mensen werken er in het bedrijf of organisatie waar u werkzaam bent? (ook eventuele andere vestigingen meetellen). 
Tabel A3.7

Beloning van werkende schoolverlaters

$\begin{array}{rrr}\text { Opleidingssector } & \text { gemiddeld } & \text { gemiddeld } \\ \text { bruto maandloon } & € & \text { bruto uurloon }\end{array}$

AVO

MAVO

$745-5,23$

HAVO

906

VWO

VBO

IVBO

655

4,36
4,57

Landbouw

662

Techniek

672

4,40

Economie

614

4,33

Gezondheidszorg

4,42

BOL niveau $1 / 2$

6,78

Landbouw

998

5,82

Techniek

885

6,89

Economie

1.117
975

6,65

Gezondheidszorg

BOL niveau 3/4

8,32

Landbouw

1.250

7,30

Techniek

1.125

1.471

Economie

1.249

8,88

Gezondheidszorg

1.232

7,92

Gedrag en maatschappij

8,77

BBL niveau 1/2

1.089

Landbouw

1.245

8,06

Techniek

1.172

7,52
8,32

1.358

Economie

1.121

7,35

Gezondheidszorg

BBL niveau 3/4

1.527

10,21

Landbouw

8,63

Techniek

1.383

1.768

Economie

1.339

1.429

10,70

Gezondheidszorg

1.354

8,32
10,64

Gedrag en maatschappij

12,02

HBO

Landbouw

Onderwijs

1.823

11,91

1.854

11,50

Techniek

1.838

1.954

1.893

Gezondheidszorg

Gedrag en maatschappij

1.686

1.628

1.443

12,31

11,87

11,72

12,54

Taal en cultuur

11,53
11,94

wo

2.191

13,83

Landbouw

1.963

12,35

Techniek

2.300

13,77

Economie

2.471

14,82

Gezondheidszorg

2.469

15,44

Gedrag en maatschappij

2.009

13,80

Taal en cultuur

1.795

12,50 
Tabel A3.7

Beloning van werkende schoolverlaters

Opleidingssector

gemiddeld

gemiddeld

bruto maandloon

bruto uurloon

$€$

WO (vervolg)

Recht en openbare orde

\section{Toelichting}

- Dit betreft het bruto inkomen in de baan waarin men het hoogste aantal uren werkt. Dit is inclusief toeslagen (ploegendienst, fooien, provisie e.d.), maar exclusief inkomen uit overwerk, vakantiegeld, $13^{e}$ maand, uitkering en dergelijke. Er is hier niet gecorrigeerd voor verschillen in leeftijd van de schoolverlaters.

- Voor het WO is het bruto uurloon gebaseerd op 13 universiteiten. 
Tabel A3.8

Vereist opleidingsniveau voor de huidige functie volgens de werkgever

\begin{tabular}{|c|c|c|c|}
\hline Opleidingssector & $\underset{\%}{\operatorname{lager}}$ & $\begin{array}{r}\text { zelfde } \\
\%\end{array}$ & $\underset{\%}{\operatorname{hoger}}$ \\
\hline $\begin{array}{l}\text { AVO } \\
\text { MAVO } \\
\text { HAVO } \\
\text { VWO }\end{array}$ & $\begin{array}{l}28 \\
20 \\
45 \\
37\end{array}$ & $\begin{array}{l}54 \\
59 \\
44 \\
46\end{array}$ & $\begin{array}{l}18 \\
21 \\
11 \\
18\end{array}$ \\
\hline $\begin{array}{l}\text { VBO } \\
\text { IVBO } \\
\text { Landbouw } \\
\text { Techniek } \\
\text { Economie } \\
\text { Gezondheidszorg }\end{array}$ & $\begin{array}{l}14 \\
25 \\
15 \\
12 \\
19 \\
10\end{array}$ & $\begin{array}{l}52 \\
44 \\
53 \\
49 \\
56 \\
59\end{array}$ & $\begin{array}{l}34 \\
31 \\
32 \\
39 \\
25 \\
31\end{array}$ \\
\hline $\begin{array}{l}\text { BOL niveau } 1 / 2 \\
\text { Landbouw } \\
\text { Techniek } \\
\text { Economie } \\
\text { Gezondheidszorg }\end{array}$ & $\begin{array}{l}40 \\
62 \\
29 \\
47 \\
30\end{array}$ & $\begin{array}{l}40 \\
36 \\
52 \\
34 \\
46\end{array}$ & $\begin{array}{r}19 \\
2 \\
19 \\
19 \\
23\end{array}$ \\
\hline $\begin{array}{l}\text { BOL niveau } 3 / 4 \\
\text { Landbouw } \\
\text { Techniek } \\
\text { Economie } \\
\text { Gezondheidszorg } \\
\text { Gedrag en maatschappij }\end{array}$ & $\begin{array}{l}31 \\
57 \\
32 \\
35 \\
22 \\
20\end{array}$ & $\begin{array}{l}64 \\
42 \\
63 \\
59 \\
76 \\
72\end{array}$ & $\begin{array}{l}5 \\
1 \\
5 \\
6 \\
2 \\
8\end{array}$ \\
\hline $\begin{array}{l}\text { BBL niveau } 1 / 2 \\
\text { Landbouw } \\
\text { Techniek } \\
\text { Economie } \\
\text { Gezondheidszorg }\end{array}$ & $\begin{array}{l}42 \\
52 \\
38 \\
57 \\
22\end{array}$ & $\begin{array}{l}36 \\
36 \\
37 \\
25 \\
53\end{array}$ & $\begin{array}{l}22 \\
13 \\
25 \\
18 \\
25\end{array}$ \\
\hline $\begin{array}{l}\text { BBL niveau } 3 / 4 \\
\text { Landbouw } \\
\text { Techniek } \\
\text { Economie } \\
\text { Gezondheidszorg } \\
\text { Gedrag en maatschappij }\end{array}$ & $\begin{array}{l}31 \\
59 \\
49 \\
37 \\
12 \\
19\end{array}$ & $\begin{array}{l}\mathbf{6 7} \\
41 \\
50 \\
61 \\
87 \\
78\end{array}$ & $\begin{array}{l}1 \\
1 \\
2 \\
1 \\
3\end{array}$ \\
\hline $\begin{array}{l}\text { HBO } \\
\text { Landbouw } \\
\text { Onderwijs } \\
\text { Techniek } \\
\text { Economie } \\
\text { Gezondheidszorg } \\
\text { Gedrag en maatschappij } \\
\text { Taal en cultuur }\end{array}$ & $\begin{array}{l}23 \\
25 \\
12 \\
18 \\
25 \\
23 \\
36 \\
36\end{array}$ & $\begin{array}{l}76 \\
74 \\
88 \\
81 \\
73 \\
76 \\
63 \\
63\end{array}$ & $\begin{array}{l}1 \\
1 \\
0 \\
1 \\
2 \\
1 \\
1 \\
2\end{array}$ \\
\hline $\begin{array}{l}\text { WO } \\
\text { Landbouw } \\
\text { Techniek } \\
\text { Economie } \\
\text { Gezondheidszorg } \\
\text { Gedrag en maatschappij } \\
\text { Taal en cultuur } \\
\text { Recht en openbare orde } \\
\text { Natuurwetenschappen }\end{array}$ & $\begin{array}{r}34 \\
36 \\
34 \\
42 \\
8 \\
45 \\
59 \\
19 \\
28\end{array}$ & $\begin{array}{l}66 \\
64 \\
66 \\
58 \\
92 \\
55 \\
41 \\
81 \\
72\end{array}$ & \\
\hline Totaal & 29 & 61 & 10 \\
\hline
\end{tabular}

Toelichting

Vraag in de enquête:

- Welk opleidingsniveau werd door uw werkgever voor deze functie minimaal vereist? 
Tabel A3.9

Vereiste opleidingsrichting voor de huidige functie volgens de werkgever

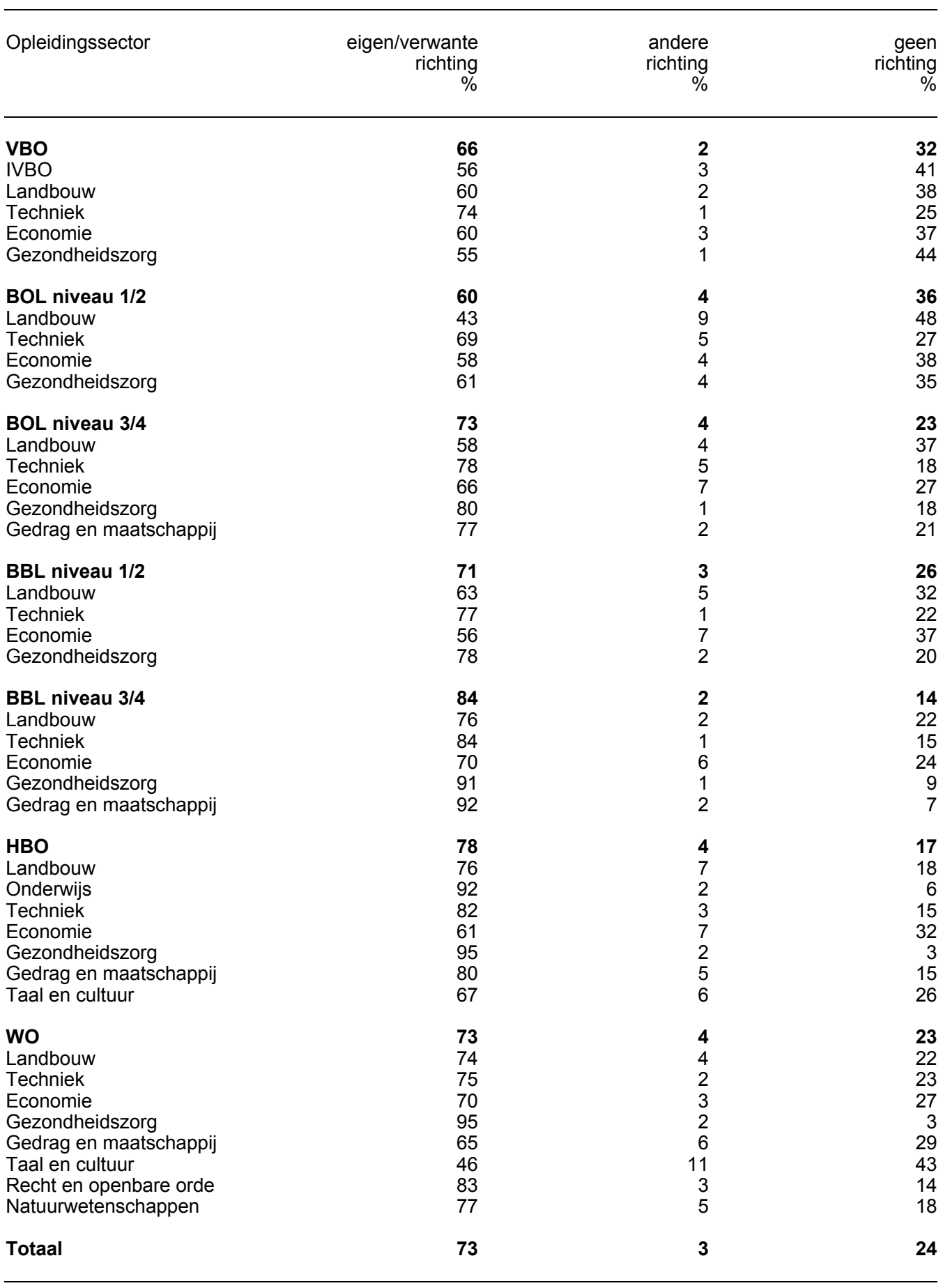

Toelichting

Vraag in de enquête:

- Welke opleidingsrichting werd door uw werkgever voor deze functie vereist? 
Tabel A3.10

Feitelijke wekelijkse arbeidsduur van werkende schoolverlaters

Opleidingssector

feitelijke

wekelijkse

arbeidsduur

uren

AVO

33,6

MAVO

33,7

HAVO

33,8

VWO

VBO

34,4

IVBO

34,6

Landbouw

33,7

Techniek

35,3

Economie

33,8

Gezondheidszorg

BOL niveau 1/2

33,8

Landbouw

Techniek

34,6
37,4

Economie

33,9

Gezondheidszorg

31,5

BOL niveau 3/4

34,8

Landbouw

36,2

Techniek

38,3

Economie

36,5

Gezondheidszorg

33,3

Gedrag en maatschappij

BBL niveau 1/2

Landbouw

Techniek

38,0

Economie

34,9

Gezondheidszorg

BBL niveau $3 / 4$

Landbouw

37,0

Techniek

38,7

Economie

36,9

Gezondheidszorg

31,6

Gedrag en maatschappij

HBO

Landbouw

Onderwijs

Techniek

Economie

38,3

Gezondheidszorg

33,7

Gedrag en maatschappij

Taal en cultuur

Wo

Landbouw

Techniek

Economie

39,4

Gezondheidszorg

Gedrag en maatschappij

35,6

Taal en cultuur 
Tabel A3.10 (vervolg)

Feitelijke wekelijkse arbeidsduur van werkende schoolverlaters

Opleidingssector

feitelijke

wekelijkse

arbeidsduur

uren

WO (vervolg)

Recht en openbare orde

39,1

Natuurwetenschappen

Totaal

35,6

Toelichting

- De feitelijke arbeidsduur betreft zowel het aantal uren in de hoofdfunctie als het aantal uren in eventuele nevenfuncties.

- Voor het WO zijn de resultaten gebaseerd op 12 universiteiten. 
Tabel A3.11

Oordeel van de werkende schoolverlaters over de aansluiting tussen de afgesloten opleiding en de huidige functie

\begin{tabular}{|c|c|c|c|c|}
\hline Opleidingssector & $\begin{array}{r}\text { goed } \\
\%\end{array}$ & $\begin{array}{r}\text { voldoende } \\
\%\end{array}$ & $\begin{array}{r}\text { matig } \\
\%\end{array}$ & $\begin{array}{r}\text { slecht } \\
\%\end{array}$ \\
\hline BOL niveau $1 / 2$ & 51 & 34 & 8 & 7 \\
\hline Landbouw & 58 & 32 & 8 & 2 \\
\hline Techniek & 47 & 31 & 11 & 10 \\
\hline Economie & 48 & 38 & 5 & 9 \\
\hline Gezondheidszorg & 56 & 30 & 10 & 4 \\
\hline BOL niveau $3 / 4$ & 42 & 39 & 12 & 7 \\
\hline Landbouw & 39 & 38 & 11 & 13 \\
\hline Techniek & 38 & 41 & 12 & 9 \\
\hline Economie & 40 & 42 & 13 & 5 \\
\hline Gezondheidszorg & 45 & 36 & 13 & 6 \\
\hline Gedrag en maatschappij & 47 & 35 & 11 & 8 \\
\hline BBL niveau $1 / 2$ & 61 & 28 & 6 & 5 \\
\hline Landbouw & 53 & 32 & 8 & 7 \\
\hline Techniek & 60 & 29 & 6 & 5 \\
\hline Economie & 63 & 24 & 8 & 6 \\
\hline Gezondheidszorg & 66 & 27 & 2 & 4 \\
\hline BBL niveau $3 / 4$ & 53 & 34 & 9 & 3 \\
\hline Landbouw & 49 & 40 & 6 & 5 \\
\hline Techniek & 53 & 35 & 9 & 3 \\
\hline Economie & 48 & 36 & 11 & 4 \\
\hline Gezondheidszorg & 56 & 32 & 10 & 2 \\
\hline Gedrag en maatschappij & 56 & 38 & 4 & 2 \\
\hline HBO & 46 & 38 & 11 & 5 \\
\hline Landbouw & 38 & 45 & 10 & 7 \\
\hline Onderwijs & 63 & 28 & 6 & 3 \\
\hline Techniek & 42 & 43 & 12 & 4 \\
\hline Economie & 38 & 40 & 15 & 7 \\
\hline Gezondheidszorg & 56 & 33 & 9 & 2 \\
\hline Gedrag en maatschappij & 42 & 41 & 11 & 7 \\
\hline Taal en cultuur & 44 & 27 & 14 & 15 \\
\hline wo & 54 & 31 & 9 & 6 \\
\hline Landbouw & 55 & 30 & 7 & 7 \\
\hline Techniek & 56 & 33 & 9 & 3 \\
\hline Economie & 55 & 34 & 8 & 3 \\
\hline Gezondheidszorg & 71 & 22 & 5 & 2 \\
\hline Gedrag en maatschappij & 45 & 34 & 13 & 8 \\
\hline Taal en cultuur & 30 & 31 & 19 & 20 \\
\hline Recht en openbare orde & 59 & 32 & 7 & 2 \\
\hline Natuurwetenschappen & 54 & 29 & 9 & 8 \\
\hline Totaal & 50 & 35 & 10 & 5 \\
\hline
\end{tabular}

\section{Toelichting}

- Voor het WO hebben de resultaten betrekking op 10 universiteiten.

Vraag in de enquête:

- Hoe vindt $u$ de aansluiting tussen uw [...] opleiding en uw huidige functie? 
Tabel A3.12

Percentage werkende schoolverlaters dat op zoek is naar een andere baan

Opleidingssector

AVo

MAVO

HAVO

VWO

VBO

IVBO

Landbouw

Techniek

Economie

Gezondheidszorg

7

BOL niveau 1/2

13

Landbouw

Techniek

Economie

Gezondheidszorg

30

14

10

BOL niveau 3/4

13

Landbouw

Techniek

Economie

Gezondheidszorg

Gedrag en maatschappij

BBL niveau $1 / 2$

Landbouw

Techniek

Economie

Gezondheidszorg

10

BBL niveau 3/4

Landbouw

Techniek

Economie

Gezondheidszorg

Gedrag en maatschappij

HBO

Landbouw

Onderwijs

Techniek

Economie

Gezondheidszorg

Gedrag en maatschappij

Taal en cultuur

wo

Landbouw

Techniek

Economie

Gezondheidszorg

Gedrag en maatschappij

Taal en cultuur

Recht en openbare orde

Natuurwetenschappen

Totaal 
Tabel A4. 1

Enkele kernindicatoren

\begin{tabular}{|c|c|c|c|c|c|c|c|c|c|}
\hline Opleidingssector & $\begin{array}{r}\text { opgehoogd } \\
\text { aantal } \\
\text { populatie }\end{array}$ & $\begin{array}{r}\text { verder } \\
\text { leren } \\
\\
\%\end{array}$ & $\begin{array}{r}\text { zelfde } \\
\text { opleiding } \\
\text { opnieuw } \\
\text { kiezen } \\
\%\end{array}$ & $\begin{array}{r}\text { werk- } \\
\text { loosheid } \\
\%\end{array}$ & $\begin{array}{r}\text { intrede } \\
\text { werk- } \\
\text { loosheid } \\
\text { maanden }\end{array}$ & $\begin{array}{r}\text { flexibele } \\
\text { aanstelling } \\
\%\end{array}$ & $\begin{array}{r}\text { bruto } \\
\text { uurloon } \\
€\end{array}$ & $\begin{array}{r}\text { minimaal } \\
\text { eigen } \\
\text { niveau } \\
\%\end{array}$ & $\begin{array}{r}\text { eigen/ } \\
\text { verwante } \\
\text { richting } \\
\%\end{array}$ \\
\hline $\begin{array}{l}\text { AVO } \\
\text { MAVO } \\
\text { HAVO } \\
\text { VWO }\end{array}$ & $\begin{array}{l}\mathbf{9 8 . 1 9 3} \\
41.363 \\
30.547 \\
26.283\end{array}$ & $\begin{array}{l}87 \\
88 \\
87 \\
84\end{array}$ & $\begin{array}{l}x \\
x \\
x \\
x\end{array}$ & $\begin{array}{l}7 \\
7 \\
8 \\
4\end{array}$ & $\begin{array}{l}\mathbf{0 , 4} \\
0,4 \\
0,7 \\
0,2\end{array}$ & $\begin{array}{l}39 \\
35 \\
48 \\
44\end{array}$ & $\begin{array}{l}\mathbf{5 , 6 8} \\
5,23 \\
6,17 \\
7,23\end{array}$ & $\begin{array}{l}72 \\
80 \\
55 \\
64\end{array}$ & $\begin{array}{l}x \\
x \\
x \\
x\end{array}$ \\
\hline $\begin{array}{l}\text { VBO } \\
\text { IVBO } \\
\text { Landbouw } \\
\text { Techniek } \\
\text { Economie } \\
\text { Gezondheidszorg }\end{array}$ & $\begin{array}{r}\mathbf{4 0 . 4 4 6} \\
3.270 \\
3.713 \\
15.203 \\
8.008 \\
10.252\end{array}$ & $\begin{array}{l}82 \\
70 \\
81 \\
82 \\
87 \\
84\end{array}$ & $\begin{array}{l}x \\
x \\
x \\
x \\
x \\
x\end{array}$ & $\begin{array}{l}3 \\
9 \\
2 \\
2 \\
5 \\
2\end{array}$ & $\begin{array}{l}\mathbf{0 , 3} \\
0,7 \\
0,3 \\
0,2 \\
0,2 \\
0,5\end{array}$ & $\begin{array}{l}24 \\
27 \\
31 \\
28 \\
18 \\
16\end{array}$ & $\begin{array}{l}4,40 \\
4,36 \\
4,57 \\
4,40 \\
4,33 \\
4,42\end{array}$ & $\begin{array}{l}86 \\
75 \\
85 \\
88 \\
81 \\
90\end{array}$ & $\begin{array}{l}66 \\
56 \\
60 \\
74 \\
60 \\
55\end{array}$ \\
\hline $\begin{array}{l}\text { BOL niveau 1/2 } \\
\text { Landbouw } \\
\text { Techniek } \\
\text { Economie } \\
\text { Gezondheidszorg }\end{array}$ & $\begin{array}{r}\mathbf{1 3 . 4 1 8} \\
431 \\
1.851 \\
7.202 \\
3.935\end{array}$ & $\begin{array}{l}43 \\
33 \\
47 \\
41 \\
47\end{array}$ & $\begin{array}{l}65 \\
64 \\
69 \\
66 \\
60\end{array}$ & $\begin{array}{r}8 \\
9 \\
4 \\
10 \\
8\end{array}$ & $\begin{array}{l}\mathbf{0 , 5} \\
1,1 \\
0,3 \\
0,5 \\
0,5\end{array}$ & $\begin{array}{l}29 \\
18 \\
23 \\
33 \\
26\end{array}$ & $\begin{array}{l}\mathbf{6 , 7 8} \\
5,82 \\
6,89 \\
6,65 \\
7,11\end{array}$ & $\begin{array}{l}\mathbf{5 9} \\
38 \\
81 \\
53 \\
69\end{array}$ & $\begin{array}{l}60 \\
43 \\
69 \\
58 \\
61\end{array}$ \\
\hline $\begin{array}{l}\text { BOL niveau } \mathbf{3 / 4} \\
\text { Landbouw } \\
\text { Techniek } \\
\text { Economie } \\
\text { Gezondheidszorg } \\
\text { Gedrag en maatschappij }\end{array}$ & $\begin{array}{r}\mathbf{5 0 . 4 2 9} \\
3.938 \\
11.133 \\
17.110 \\
7.636 \\
10.612\end{array}$ & $\begin{array}{l}48 \\
40 \\
55 \\
49 \\
28 \\
55\end{array}$ & $\begin{array}{l}77 \\
68 \\
83 \\
72 \\
74 \\
85\end{array}$ & $\begin{array}{l}4 \\
3 \\
5 \\
5 \\
1 \\
6\end{array}$ & $\begin{array}{l}\mathbf{0 , 4} \\
0,3 \\
0,4 \\
0,5 \\
0,2 \\
0,4\end{array}$ & $\begin{array}{l}22 \\
25 \\
21 \\
29 \\
11 \\
21\end{array}$ & $\begin{array}{l}8,32 \\
7,30 \\
8,88 \\
7,92 \\
8,45 \\
8,77\end{array}$ & $\begin{array}{l}69 \\
43 \\
68 \\
65 \\
78 \\
80\end{array}$ & $\begin{array}{l}73 \\
58 \\
78 \\
66 \\
80 \\
77\end{array}$ \\
\hline $\begin{array}{l}\text { BBL niveau 1/2 } \\
\text { Landbouw } \\
\text { Techniek } \\
\text { Economie } \\
\text { Gezondheidszorg }\end{array}$ & $\begin{array}{r}20.828 \\
1.771 \\
11.170 \\
5.182 \\
2.705\end{array}$ & $\begin{array}{l}31 \\
28 \\
38 \\
20 \\
23\end{array}$ & $\begin{array}{l}75 \\
67 \\
78 \\
65 \\
84\end{array}$ & $\begin{array}{l}2 \\
1 \\
2 \\
4 \\
1\end{array}$ & $\begin{array}{l}\mathbf{0 , 3} \\
0,3 \\
0,4 \\
0,4 \\
0,1\end{array}$ & $\begin{array}{r}15 \\
4 \\
13 \\
22 \\
14\end{array}$ & $\begin{array}{l}8,06 \\
7,52 \\
8,32 \\
7,35 \\
8,86\end{array}$ & $\begin{array}{l}\mathbf{5 8} \\
49 \\
62 \\
43 \\
78\end{array}$ & $\begin{array}{l}71 \\
63 \\
77 \\
56 \\
78\end{array}$ \\
\hline $\begin{array}{l}\text { BBL niveau } 3 / 4 \\
\text { Landbouw }\end{array}$ & $\begin{array}{r}18.075 \\
964\end{array}$ & $\begin{array}{l}16 \\
25\end{array}$ & $\begin{array}{l}80 \\
80\end{array}$ & $\begin{array}{l}1 \\
0\end{array}$ & $\begin{array}{l}\mathbf{0 , 1} \\
0,2\end{array}$ & $\begin{array}{l}5 \\
0\end{array}$ & $\begin{array}{r}10,21 \\
8,63\end{array}$ & $\begin{array}{l}68 \\
41\end{array}$ & $\begin{array}{l}84 \\
76\end{array}$ \\
\hline
\end{tabular}


Tabel A4.1 (vervolg)

Enkele kernindicatoren

\begin{tabular}{|c|c|c|c|c|c|c|c|c|c|}
\hline Opleidingssector & $\begin{array}{r}\text { opgehoogd } \\
\text { aantal } \\
\text { populatie }\end{array}$ & $\begin{array}{r}\text { verder } \\
\text { leren } \\
\\
\%\end{array}$ & $\begin{array}{r}\text { zelfde } \\
\text { opleiding } \\
\text { opnieuw } \\
\text { kiezen } \\
\%\end{array}$ & $\begin{array}{r}\text { werk- } \\
\text { loosheid } \\
\%\end{array}$ & $\begin{array}{r}\text { intrede } \\
\text { werk- } \\
\text { loosheid } \\
\text { maanden }\end{array}$ & $\begin{array}{r}\text { flexibele } \\
\text { aanstelling } \\
\%\end{array}$ & $\begin{array}{r}\text { bruto } \\
\text { uurloon } \\
€\end{array}$ & $\begin{array}{r}\text { minimaal } \\
\text { eigen } \\
\text { niveau } \\
\%\end{array}$ & $\begin{array}{r}\text { eigen/ } \\
\text { verwante } \\
\text { richting } \\
\%\end{array}$ \\
\hline \multicolumn{10}{|l|}{ BBL niveau $\mathbf{3 / 4}$ (vervolg) } \\
\hline Techniek & 6.225 & 22 & 83 & 1 & 0,1 & 4 & 10,70 & 51 & 84 \\
\hline Economie & 3.169 & 9 & 70 & 3 & 0,3 & 15 & 8,32 & 63 & 70 \\
\hline Gezondheidszorg & 7.099 & 13 & 83 & 0 & 0,1 & 3 & 10,64 & 88 & 91 \\
\hline Gedrag en maatschappij & 618 & 5 & 81 & 4 & 0,5 & 9 & 12,02 & 81 & 92 \\
\hline HBO & 42.935 & 27 & 76 & 3 & 0,7 & 13 & 11,91 & 77 & 78 \\
\hline Landbouw & 1.758 & 25 & 77 & 4 & 0,8 & 14 & 11,50 & 75 & 76 \\
\hline Onderwijs & 6.986 & 24 & 85 & 2 & 0,4 & 7 & 12,31 & 88 & 92 \\
\hline Techniek & 9.028 & 27 & 78 & 3 & 0,7 & 11 & 11,87 & 82 & 82 \\
\hline Economie & 13.043 & 32 & 69 & 4 & 0,9 & 16 & 11,72 & 75 & 61 \\
\hline Gezondheidszorg & 4.343 & 22 & 80 & 2 & 0,3 & 10 & 12,54 & 77 & 95 \\
\hline Gedrag en maatschappij & 6.071 & 22 & 74 & 3 & 0,8 & 16 & 11,53 & 64 & 80 \\
\hline Taal en cultuur & 1.705 & 27 & 86 & 7 & 1,7 & 20 & 11,94 & 65 & 67 \\
\hline wo & 18.850 & 27 & 80 & 3 & 1,1 & 11 & 13,83 & 66 & 73 \\
\hline Landbouw & 617 & 26 & 74 & 4 & 1,4 & 11 & 12,35 & 64 & 74 \\
\hline Techniek & 2.790 & 18 & 81 & 3 & 1,3 & 8 & 13,77 & 66 & 75 \\
\hline Economie & 2.752 & 22 & 80 & 1 & 1,0 & 7 & 14,82 & 58 & 70 \\
\hline Gezondheidszorg & 2.334 & 42 & 87 & 1 & 0,7 & 6 & 15,44 & 92 & 95 \\
\hline Gedrag en maatschappij & 4.007 & 20 & 78 & 4 & 1,3 & 16 & 13,80 & 55 & 65 \\
\hline Taal en cultuur & 2.184 & 29 & 72 & 5 & 1,3 & 19 & 12,50 & 41 & 46 \\
\hline Recht en openbare orde & 2.390 & 27 & 85 & 2 & 1,1 & 7 & 13,86 & 81 & 83 \\
\hline Natuurwetenschappen & 1.775 & 47 & 77 & 2 & 1,1 & 13 & 12,30 & 72 & 77 \\
\hline Totaal & 303.175 & 58 & 76 & 3 & 0,5 & 18 & 9,35 & 71 & 73 \\
\hline
\end{tabular}

$\mathrm{x}=$ vraag niet opgenomen

Toelichting

- Deze tabel geeft een samenvattend beeld. Zie ook de tabellen C.2, A2.1, A1.4, A3.1, A3.3, A3.7, A3.8 en A3.9. 
B. Tabellen per opleidingsrichting 



\section{Inhoud}

1 Bestemming van schoolverlaters

B1.1 De uitstroom van schoolverlaters verbijzonderd naar geslacht, etniciteit en gemiddelde leeftijd op moment van enquête

B1.2 Vooropleiding van schoolverlaters

B1.3 Bestemming van schoolverlaters

B1.4 Gevolgde opleiding opnieuw kiezen?

2 Doorstroom naar vervolgonderwijs

B2.1 Doorstroom van schoolverlaters naar vervolgonderwijs

B2.2 Belangrijkste opleidingen van schoolverlaters die een vervolgopleiding zijn gaan volgen

B2.3 Oordeel van schoolverlaters over de aansluiting van de afgesloten opleiding met de vervolgopleiding

B2.4 Doorstroom van schoolverlaters naar kenniscentrum beroepsonderwijs bedrijfsleven

3 Intrede op de arbeidsmarkt

B3.1 Werkloosheid en gemiddelde intredewerkloosheid van schoolverlaters die zich aanbieden op de arbeidsmarkt

B3.2 Aard van het dienstverband van werkende schoolverlaters

B3.3 Percentage werkende schoolverlaters met een flexibele aanstelling

B3.4 Belangrijkste bedrijfsgroepen waarin schoolverlaters werkzaam zijn

B3.5 Belangrijkste beroepsgroepen waarin schoolverlaters werkzaam zijn

B3.6 Grootte van de organisatie waarin schoolverlaters werkzaam zijn

B3.7 Beloning van werkende schoolverlaters

B3.8 Vereist opleidingsniveau voor de huidige functie volgens de werkgever

B3.9 Vereiste opleidingsrichting voor de huidige functie volgens de werkgever

B3.10 Feitelijke wekelijkse arbeidsduur van werkende schoolverlaters

B3.11 Oordeel van de werkende schoolverlaters over de aansluiting tussen de afgesloten opleiding en de huidige functie

B3.12 Percentage werkende schoolverlaters dat op zoek is naar een andere baan

\section{Kernindicatoren}

B4.1 Enkele kernindicatoren 
Tabel B1.1

De uitstroom van schoolverlaters verbijzonderd naar geslacht, etniciteit en gemiddelde leeftijd op moment van enquête

\begin{tabular}{l}
\hline Opleidingsrichting \\
\hline VBO \\
IVBO Landbouw en natuurlijke omgeving \\
IVBO Bouwtechniek \\
IVBO Verzorging \\
Landbouw en natuurlijke omgeving \\
Bouwtechniek \\
Mechanische techniek \\
Elektrotechniek \\
Motorvoertuigentechniek \\
Consumptieve techniek \\
Nautische opleidingen \\
Administratie \\
Verkoop \\
Verzorging \\
Uiterlijke verzorging
\end{tabular}

$\begin{array}{rrr} & \\ \% & \text { allochtoon } & \text { leeftijd } \\ \% & \text { gem. }\end{array}$

BOL niveau $1 / 2$

$A B$ Motorvoertuigen

$A B$ Beveiliging

$A B$ Secretarieel

$A B$ Verpleging en verzorging

BB Plantenteelt

BB Bloemschikken

BB Dierverzorging en veterinaire ondersteuning

BB Groene ruimte

BB Houtbewerking en woninginrichting

BB Reclame, presentatie en communicatie

BB Motorvoertuigen

BB Graf. techn, communicatie, audiovisueel en multimedia

BB Bedrijfsadministratie

BB Secretarieel

BB Detailhandel/ambulante handel

BB Horeca, instellingskeuken en contractcatering

BB Facilitaire dienstverlening

BB Verpleging en verzorging

$\begin{array}{rrr}42 & 7 & 17,8 \\ 6 & 0 & 17,9 \\ 96 & 4 & 17,8 \\ 54 & 3 & 17,6 \\ 2 & 2 & 17,4 \\ 3 & 3 & 17,7 \\ 2 & 4 & 17,5 \\ 3 & 6 & 17,8 \\ 24 & 3 & 17,7 \\ 6 & 0 & 17,5 \\ 66 & 22 & 17,4 \\ 46 & 20 & 17,4 \\ 92 & 4 & 17,4 \\ 99 & 12 & 17,6\end{array}$

BOL niveau $3 / 4$

ZB Plantenteelt

ZB Veehouderij

ZB Levensmiddelentechnologie

ZB Bloemschikken

ZB Dierverzorging en veterinaire ondersteuning

ZB Paardenhouderij en paardensport

ZB Groene ruimte

ZB Werktuigbouwkunde

ZB Graf. techn, communicatie, audiovisueel en multimedia

ZB Scheepvaart

ZB Bedrijfsadministratief

ZB Detailhandel/ambulante handel

ZB Groothandel/distributie

ZB Toerisme, recreatie en reizen

$Z B$ Verpleging en verzorging

ZB Uiterlijke verzorging

KF Plantenteelt

KF Veehouderij

KF Levensmiddelentechnologie

KF Bloemschikken

$\begin{array}{rrr}0 & 18 & 18,6 \\ 34 & 7 & 19,3 \\ 80 & 60 & 24,1 \\ 100 & 26 & 19,4 \\ 5 & 0 & 19,7 \\ 90 & 7 & 20,4 \\ 73 & 0 & 21,3 \\ 0 & 0 & 19,6 \\ 17 & 4 & 20,7 \\ 57 & 10 & 20,8 \\ 0 & 27 & 21,2 \\ 36 & 14 & 20,4 \\ 61 & 39 & 20,1 \\ 96 & 10 & 20,4 \\ 61 & 23 & 19,8 \\ 38 & 4 & 19,9 \\ 78 & 16 & 20,8 \\ 96 & 12 & 20,0\end{array}$


Tabel B1.1 (vervolg)

De uitstroom van schoolverlaters verbijzonderd naar geslacht, etniciteit en gemiddelde leeftijd op moment van enquête

\begin{tabular}{lrr}
\hline Opleidingsrichting & vrouw & allochtoon \\
$\%$ & $\begin{array}{r}\text { leeftijd } \\
\text { gem. }\end{array}$
\end{tabular}

BOL niveau 3/4 (vervolg)

KF Dierverzorging en veterinaire ondersteuning

KF Paardenhouderij en paardensport

KF Groene ruimte

KF Milieutoezicht

MKF Bouw

MKF Houtbewerking en woninginrichting

MKF Grond-, water- en wegenbouw

MKF Beschermings-en afwerkingstechnieken

MKF Reclame, presentatie en communicatie

MKF Operationele techniek

MKF Werktuigbouwkunde

MKF Motorvoertuigen

MKF Energie- en informatietechniek

MKF Energietechniek

MKF Informatietechniek

MKF Graf. techn, communicatie, audiovisueel en multimedia

MKF Laboratoriumtechniek

MKF Procestechniek

MKF Scheepvaart

MKF Transport en logistiek

MKF Automatisering

MKF Bedrijfsadministratief

MKF Commercieel

MKF Economisch-juridisch

MKF Secretarieel

MKF Detailhandel/ambulante handel

MKF Groothandel/distributie

MKF Horeca, instellingskeuken en contractcatering

MKF Toerisme, recreatie en reizen

MKF Assistenten gezondheidszorg

MKF Facilitaire dienstverlening

MKF Sport en bewegen

MKF Verpleging en verzorging

MKF Maatschappelijke dienstverlening

MKF Sociaal-pedagogisch werk algemeen

MKF Sociaal-juridisch werk

$\begin{array}{rrr}88 & 1 & 21,4 \\ 88 & 4 & 21,0 \\ 12 & 1 & 21,6 \\ 21 & 2 & 21,8 \\ 9 & 3 & 21,9 \\ 51 & 4 & 22,7 \\ 2 & 0 & 22,1 \\ 60 & 0 & 22,0 \\ 68 & 7 & 22,1 \\ 3 & 0 & 24,0 \\ 2 & 2 & 21,7 \\ 0 & 0 & 21,7 \\ 0 & 2 & 21,8 \\ 0 & 0 & 21,9 \\ 1 & 6 & 22,0 \\ 39 & 7 & 22,8 \\ 53 & 11 & 22,5 \\ 10 & 8 & 21,9 \\ 5 & 7 & 22,9 \\ 49 & 1 & 21,8 \\ 7 & 0 & 22,0 \\ 54 & 9 & 21,2 \\ 58 & 12 & 21,5 \\ 67 & 12 & 21,2 \\ 99 & 16 & 21,4 \\ 48 & 12 & 21,1 \\ 20 & 1 & 21,1 \\ 56 & 4 & 22,0 \\ 89 & 6 & 22,0 \\ 99 & 7 & 21,3 \\ 52 & 0 & 21,5 \\ 36 & 2 & 21,9 \\ 90 & 1 & 22,8 \\ 77 & 22 & 21,1 \\ 93 & 4 & 21,3 \\ 64 & 9 & 25,5\end{array}$

BBL niveau $1 / 2$

$A B$ Groene ruimte

$A B$ Beveiliging

$A B$ Detailhandel/ambulante handel

$A B$ Verpleging en verzorging

BB Plantenteelt

BB Bloemschikken

BB Groene ruimte

BB Bouw

BB Houtbewerking en woninginrichting

BB Grond-, water en wegenbouw

BB Beschermings- en afwerkingstechnieken

BB Constructie-, plaatwerken/pijpenbewerken

BB Montage/onderhoud/operationele techniek

BB Motorvoertuigen

BB Energie- en informatietechniek

BB Energietechniek

BB Installatie-, service- en onderhoudstechniek

BB Procestechniek

BB Wegvervoer

$\begin{array}{rrr}2 & 6 & 31,4 \\ 21 & 25 & 40,4 \\ 70 & 7 & 21,5 \\ 95 & 15 & 39,7 \\ 8 & 2 & 21,0 \\ 96 & 6 & 21,7 \\ 4 & 5 & 29,7 \\ 3 & 1 & 20,7 \\ 2 & 11 & 20,9 \\ 0 & 0 & 24,8 \\ 0 & 0 & 20,9 \\ 0 & 10 & 21,3 \\ 0 & 7 & 32,4 \\ 0 & 9 & 23,0 \\ 0 & 13 & 24,0 \\ 0 & 0 & 25,9 \\ 0 & 1 & 22,8 \\ 6 & 4 & 37,0 \\ 5 & 5 & 21,4\end{array}$


Tabel B1.1 (vervolg)

De uitstroom van schoolverlaters verbijzonderd naar geslacht, etniciteit en gemiddelde leeftijd op moment van enquête

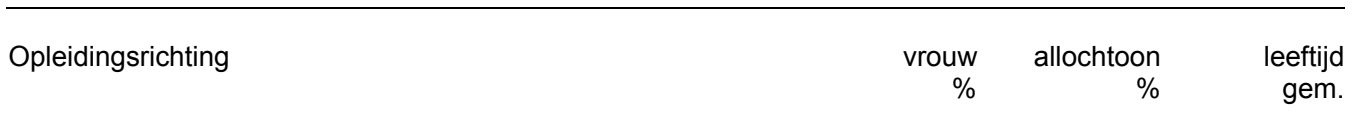

BBL niveau $1 / 2$ (vervolg)

BB Detailhandel/ambulante handel

BB Opslag/magazijn

BB Horeca, instellingskeuken en contractcatering

BB Facilitaire dienstverlening

$B B$ Verpleging en verzorging

BB Uiterlijke verzorging

$\begin{array}{rrr}73 & 5 & 20,1 \\ 19 & 23 & 32,9 \\ 43 & 0 & 20,3 \\ 100 & 11 & 34,5 \\ 98 & 12 & 35,9 \\ 100 & 7 & 20,3\end{array}$

BBL niveau $3 / 4$

ZB Plantenteelt

ZB Bloemschikken

ZB Groene ruimte

ZB Bouw

ZB Grond-, water- en wegenbouw

ZB Constructie-, plaatwerken/pijpenbewerken

ZB Motorvoertuigen

ZB Energie- en informatietechniek

ZB Energietechniek

ZB Beheer, ontwerp en management (instal. techn)

ZB Installatie-, service- en onderhoudstechniek

ZB Procestechniek

ZB Automatisering

ZB Detailhandel/ambulante handel

ZB Opslag/magazijn

ZB Horeca, instellingskeuken en contractcatering

$Z B$ Verpleging en verzorging

ZB Uiterlijke verzorging

MKF Bouw

MKF Detailhandel/ambulante handel

MKF Horeca, instellingskeuken en contractcatering

MKF Verpleging en verzorging

MKF Sociaal-pedagogisch werk

Specialist Energietechniek

Specialist Verpleging en verzorging

$\begin{array}{rrr}11 & 0 & 22,2 \\ 81 & 5 & 23,5 \\ 8 & 5 & 29,1 \\ 0 & 3 & 22,4 \\ 0 & 0 & 23,4 \\ 0 & 3 & 24,7 \\ 0 & 11 & 24,6 \\ 0 & 0 & 28,3 \\ 0 & 5 & 25,6 \\ 0 & 5 & 30,5 \\ 0 & 9 & 25,1 \\ 0 & 13 & 35,1 \\ 0 & 4 & 22,7 \\ 60 & 7 & 21,5 \\ 6 & 14 & 33,8 \\ 32 & 4 & 22,3 \\ 97 & 2 & 32,3 \\ 100 & 5 & 20,9 \\ 0 & 0 & 27,8 \\ 57 & 6 & 22,0 \\ 35 & 0 & 21,5 \\ 83 & 3 & 27,6 \\ 75 & 8 & 37,6 \\ 1 & 4 & 31,7 \\ 95 & 0 & 39,4\end{array}$

Zie ook toelichting bladzijde 5 
Tabel B1.2

Vooropleiding van schoolverlaters

\begin{tabular}{lrrrrr}
\hline Opleidingsrichting & MAVO & HAVO & VWO & VBO \\
$\%$ & & $\begin{array}{r}\text { BOL } \\
\%\end{array}$ & $\begin{array}{r}\text { BBL } \\
\%\end{array}$ & $\begin{array}{r}\text { overig } \\
\%\end{array}$
\end{tabular}

BOL niveau 1/2

AB Motorvoertuigen

$A B$ Beveiliging

AB Secretarieel

$A B$ Verpleging en verzorging

BB Plantenteelt

BB Bloemschikken

BB Dierverzorging en veterinaire ondersteuning

BB Houtbewerking en woninginrichting

BB Reclame, presentatie en communicatie

BB Motorvoertuigen

BB Graf. techn, communicatie, audiovisueel en multimedia

BB Bedrijfsadministratie

BB Secretarieel

BB Detailhandel/ambulante handel

BB Horeca, instellingskeuken en contractcatering

BB Facilitaire dienstverlening

$B B$ Verpleging en verzorging

BOL niveau $3 / 4$

ZB Plantenteelt

ZB Veehouderij

ZB Levensmiddelentechnologie

ZB Bloemschikken

ZB Dierverzorging en veterinaire ondersteuning

ZB Paardenhouderij en paardensport

ZB Groene ruimte

ZB Werktuigbouwkunde

ZB Graf. techn, communicatie, audiovisueel en multimedia

ZB Scheepvaart

$\begin{array}{rrl}19 & 0 & 0 \\ 55 & 4 & 0 \\ 15 & 8 & 0 \\ 5 & 0 & 0 \\ 18 & 0 & 0 \\ 4 & 0 & 0 \\ 6 & 0 & 0 \\ 0 & 4 & 0 \\ 33 & 2 & 0 \\ 42 & 4 & 0 \\ 27 & 0 & 0 \\ 59 & 0 & 0 \\ 38 & 4 & 0 \\ 22 & 0 & 0 \\ 21 & 0 & 0 \\ 20 & 0 & 1 \\ 25 & 17 & 0 \\ 8 & 0 & 0 \\ & & \\ 25 & 4 & 0 \\ 14 & 3 & 0 \\ 16 & 0 & 0 \\ 20 & 1 & 1 \\ 37 & 0 & 1 \\ 48 & 0 & 0 \\ 22 & 1 & 1 \\ 47 & 24 & 0 \\ 50 & 0 & 0 \\ 36 & 2 & 0\end{array}$


Tabel B1.2 (vervolg)

Vooropleiding van schoolverlaters

\begin{tabular}{|c|c|c|c|c|c|c|}
\hline Opleidingsrichting & $\begin{array}{r}\text { MAVO } \\
\%\end{array}$ & $\begin{array}{r}\text { HAVO } \\
\%\end{array}$ & $\begin{array}{r}\text { VWO } \\
\%\end{array}$ & $\begin{array}{r}\text { VBO } \\
\%\end{array}$ & $\begin{array}{r}\mathrm{BOL} \\
\%\end{array}$ & $\begin{array}{r}\text { BBL } \\
\%\end{array}$ \\
\hline
\end{tabular}

BOL niveau 3/4 (vervolg)

ZB Bedrijfsadministratief

ZB Groothandel/distributie

ZB Toerisme, recreatie en reizen

ZB Verpleging en verzorging

ZB Uiterlijke verzorging

KF Plantenteelt

KF Veehouderi

KF Levensmiddelentechnologie

KF Bloemschikken

KF Dierverzorging en veterinaire ondersteuning

KF Paardenhouderij en paardensport

KF Groene ruimte

KF Milieutoezich

MKF Bouw

MKF Houtbewerking en woninginrichting

MKF Grond-, water- en wegenbouw

MKF Beschermings- en afwerkingstechnieken

MKF Reclame, presentatie en communicalie

MKF Operationele techniek

MKF Werktuigbouwkunde

MKF Motorvoertuigen

MKF Energie- en informatietechniek

MKF Energietechniek

MKF Informatietechniek

MKF Graf. techn, communicatie, audiovisueel en multimedia

MKF Laboratoriumtechniek

MKF Procestechniek

MKF Scheepvaart
MKF Transport en logistiek

MKF Automatisering

$\begin{array}{rr}57 & 0 \\ 65 & 0 \\ 73 & 14 \\ 72 & 9 \\ 39 & 2 \\ 57 & 17 \\ 68 & 5 \\ 51 & 8 \\ 63 & 9 \\ 66 & 7 \\ 46 & 38 \\ 66 & 24 \\ 66 & 8 \\ 84 & 10 \\ 62 & 14 \\ 45 & 24 \\ 69 & 19 \\ 58 & 13 \\ 58 & 37 \\ 51 & 18 \\ 55 & 24 \\ 83 & 3 \\ 49 & 8 \\ 56 & 0 \\ 61 & 9 \\ 55 & 28 \\ 79 & 15 \\ 88 & 5 \\ 70 & 13 \\ 53 & 29 \\ 71 & 3\end{array}$

$\begin{array}{rl}0 & 0 \\ 0 & 0 \\ 14 & 0 \\ 9 & 1 \\ 2 & 0 \\ 17 & 0 \\ 5 & 0 \\ 8 & 0 \\ 9 & 0 \\ 7 & 0 \\ 38 & 3 \\ 24 & 0 \\ 8 & 0 \\ 10 & 0 \\ 14 & 0 \\ 24 & 3 \\ 19 & 2 \\ 13 & 2 \\ 37 & 0 \\ 18 & 0 \\ 24 & 0 \\ 3 & 0 \\ 8 & 0 \\ 0 & 0 \\ 9 & 1 \\ 28 & 0 \\ 15 & 0 \\ 5 & 0 \\ 13 & 0 \\ 29 & 0 \\ 3 & 0\end{array}$


Tabel B1.2 (vervolg)

Vooropleiding van schoolverlaters

\begin{tabular}{|c|c|c|c|c|c|c|c|}
\hline Opleidingsrichting & $\begin{array}{r}\text { MAVO } \\
\%\end{array}$ & $\begin{array}{r}\text { HAVO } \\
\%\end{array}$ & $\begin{array}{r}\text { VWO } \\
\%\end{array}$ & $\begin{array}{r}\text { VBO } \\
\%\end{array}$ & $\begin{array}{r}\mathrm{BOL} \\
\%\end{array}$ & $\begin{array}{r}\text { BBL } \\
\%\end{array}$ & $\begin{array}{r}\text { overig } \\
\%\end{array}$ \\
\hline
\end{tabular}

BOL niveau 3/4 (vervolg)

MKF Bedrijfsadministratie

MKF Commercieel

MKF Economisch-juridisch

MKF Secretarieel

MKF Detailhandel/ambulante hande

MKF Groothandel/distributie

MKF Horeca, instellingskeuken en contractcatering

MKF Toerisme, recreatie en reizen

MKF Assistenten gezondheidszorg

MKF Facilitaire dienstverlening

MKF Sport en bewegen

MKF Verpleging en verzorging

MKF Maatschappelijke dienstverlening

MKF Sociaal-pedagogisch werk algemeen

MKF Sociaal-juridisch werk

$B B L$ niveau $1 / 2$

$A B$ Groene ruimte

$A B$ Beveiliging

$A B$ Detailhandel/ambulante handel

$A B$ Verpleging en verzorging

BB Bloemschikken

BB Groene ruimte

BB Bouw

BB Houtbewerking en woninginrichting

BB Grond-, water en wegenbouw

BB Beschermings- en afwerkingstechnieken

BB Constructie-, plaatwerken/pijpenbewerken

BB Montage/onderhoud/operationele techniek

BB Motorvoertuigen

$\begin{array}{ll}60 & 2 \\ 79 & 1 \\ 62 & 1 \\ 68 & 1 \\ 60 & \\ 75 & \\ 56 & 30 \\ 64 & 3 \\ 64 & 1 \\ 47 & 17 \\ 68 & 1 \\ 72 & \\ 71 & \\ 65 & \\ 65 & 13\end{array}$


Tabel B1.2 (vervolg)

Vooropleiding van schoolverlaters

\begin{tabular}{|c|c|c|c|c|c|c|c|}
\hline Opleidingsrichting & $\begin{array}{r}\text { MAVO } \\
\%\end{array}$ & $\begin{array}{r}\text { HAVO } \\
\%\end{array}$ & $\begin{array}{r}\text { VWO } \\
\%\end{array}$ & $\begin{array}{r}\text { VBO } \\
\%\end{array}$ & $\begin{array}{r}\mathrm{BOL} \\
\%\end{array}$ & $\begin{array}{r}\text { BBL } \\
\%\end{array}$ & $\begin{array}{r}\text { overig } \\
\%\end{array}$ \\
\hline
\end{tabular}

BBL niveau 1/2 (vervolg)

BB Energie- en informatietechniek

BB Energietechniek

BB Installatie-, service- en onderhoudstechniek

BB Procestechniek

BB Wegvervoer

BB Detailhandel/ambulante handel

BB Opslag/magazijn

BB Horeca, instellingskeuken en contractcatering

BB Facilitaire dienstverlening

BB Verpleging en verzorging

BB Uiterlijke verzorging

BBL niveau $3 / 4$

ZB Plantenteelt

ZB Bloemschikken

ZB Groene ruimte

ZB Bouw

ZB Grond-, water- en wegenbouw

ZB Grond-, water-en wegenbouw

ZB Motorvoertuigen

ZB Energie- en informatietechniek

ZB Energietechniek

ZB Beheer, ontwerp en management (instal. techn)

ZB Installatie-, service- en onderhoudstechniek

ZB Procestechniek

ZB Automatisering

ZB Detailhandel/ambulante handel

ZB Opslag/magazijn

ZB Horeca, instellingskeuken en contractcatering

ZB Verpleging en verzorging

ZB Uiterlijke verzorging

$\begin{array}{rr}0 & 0 \\ 17 & 3 \\ 16 & 1 \\ 23 & 5 \\ 31 & 6 \\ 33 & 1 \\ 20 & 18 \\ 32 & 5 \\ 11 & 17 \\ 15 & 1 \\ 33 & 7\end{array}$

$\begin{array}{rrrr}75 & 0 & 0 & 13 \\ 75 & 0 & 0 & 3 \\ 61 & 1 & 18 & 3 \\ 44 & 9 & 5 & 14 \\ 56 & 0 & 5 & 0 \\ 56 & 0 & 10 & 0 \\ 21 & 10 & 5 & 26 \\ 51 & 3 & 7 & 1 \\ 67 & 0 & 0 & 6 \\ 38 & 5 & 17 & 21 \\ 58 & 0 & 0 & 3\end{array}$

$\begin{array}{rrrrrrr}28 & 0 & 0 & 43 & 0 & 27 & 2 \\ 28 & 2 & 0 & 48 & 4 & 11 & 6 \\ 31 & 5 & 1 & 37 & 5 & 18 & 3 \\ 18 & 1 & 6 & 52 & 2 & 21 & 1 \\ 26 & 3 & 3 & 62 & 0 & 3 & 3 \\ 26 & 0 & 0 & 28 & 3 & 36 & 7 \\ 16 & 0 & 0 & 68 & 0 & 11 & 5 \\ 6 & 0 & 0 & 35 & 6 & 41 & 12 \\ 13 & 0 & 3 & 69 & 5 & 8 & 3 \\ 16 & 5 & 5 & 53 & 0 & 0 & 21 \\ 10 & 2 & 0 & 48 & 2 & 29 & 8 \\ 41 & 27 & 0 & 14 & 5 & 5 & 9 \\ 83 & 0 & 0 & 4 & 4 & 9 & 0 \\ 44 & 7 & 0 & 37 & 0 & 12 & 0 \\ 34 & 6 & 0 & 20 & 0 & 20 & 19 \\ 27 & 7 & 0 & 50 & 2 & 14 & 0 \\ 34 & 6 & 0 & 36 & 4 & 9 & 11 \\ 43 & 7 & 0 & 48 & 0 & 2 & 0\end{array}$


Tabel B1.2 (vervolg)

Vooropleiding van schoolverlaters

\begin{tabular}{|c|c|c|c|c|c|c|c|}
\hline Opleidingsrichting & $\begin{array}{r}\text { MAVO } \\
\%\end{array}$ & $\begin{array}{r}\text { HAVO } \\
\%\end{array}$ & $\begin{array}{r}\text { VWO } \\
\%\end{array}$ & $\begin{array}{r}\text { VBO } \\
\%\end{array}$ & $\begin{array}{r}\mathrm{BOL} \\
\%\end{array}$ & $\begin{array}{r}\text { BBL } \\
\%\end{array}$ & $\begin{array}{r}\text { overig } \\
\%\end{array}$ \\
\hline \multicolumn{8}{|l|}{ BBL niveau 3/4 (vervolg) } \\
\hline MKF Bouw & 6 & 12 & 0 & 65 & 0 & 12 & 6 \\
\hline MKF Detailhandel/ambulante handel & 33 & 5 & 5 & 41 & 0 & 12 & 5 \\
\hline MKF Horeca, instellingskeuken en contractcatering & 56 & 14 & 6 & 24 & 0 & 0 & 0 \\
\hline MKF Verpleging en verzorging & 46 & 29 & 3 & 11 & 0 & 3 & g \\
\hline MKF Sociaal-pedagogisch werk & 24 & 10 & 2 & 31 & 1 & 5 & 27 \\
\hline Specialist Energietechniek & 12 & 0 & 0 & 40 & 4 & 16 & 29 \\
\hline Specialist Verpleging en verzorging & 45 & 15 & 0 & 10 & 0 & 20 & 10 \\
\hline
\end{tabular}


Tabel B1.3

Bestemming van schoolverlaters

\begin{tabular}{|c|c|c|c|c|c|}
\hline Opleidingsrichting & $\begin{array}{r}\text { studie } \\
\%\end{array}$ & $\begin{array}{r}\text { BBL } \\
\%\end{array}$ & $\begin{array}{r}\text { betaald } \\
\text { werk } \\
\%\end{array}$ & $\begin{array}{r}\text { werk- } \\
\text { loos } \\
\%\end{array}$ & $\begin{array}{r}\text { anders } \\
\%\end{array}$ \\
\hline \multicolumn{6}{|l|}{ VBo } \\
\hline IVBO Landbouw en natuurlijke omgeving & 38 & 24 & 32 & 3 & 2 \\
\hline IVBO Bouwtechniek & 13 & 40 & 40 & 7 & 0 \\
\hline IVBO Verzorging & 43 & 9 & 39 & 4 & 4 \\
\hline Landbouw en natuurlijke omgeving & 56 & 18 & 22 & 2 & 3 \\
\hline Bouwtechniek & 24 & 44 & 29 & 1 & 2 \\
\hline Mechanische techniek & 47 & 29 & 18 & 0 & 5 \\
\hline Elektrotechniek & 53 & 31 & 12 & 1 & 3 \\
\hline Motorvoertuigentechniek & 31 & 46 & 20 & 0 & 3 \\
\hline Consumptieve techniek & 26 & 55 & 13 & 3 & 3 \\
\hline Nautische opleidingen & 38 & 55 & 6 & 0 & 0 \\
\hline Administratie & 72 & 12 & 13 & 0 & 3 \\
\hline Verkoop & 48 & 29 & 21 & 2 & 0 \\
\hline Verzorging & 67 & 18 & 10 & 0 & 5 \\
\hline Uiterlijke verzorging & 42 & 36 & 20 & 2 & 0 \\
\hline \multicolumn{6}{|l|}{ BOL niveau $1 / 2$} \\
\hline AB Motorvoertuigen & 12 & 53 & 29 & 0 & 6 \\
\hline AB Beveiliging & 25 & 2 & 67 & 4 & 2 \\
\hline AB Secretarieel & 47 & 0 & 27 & 27 & 0 \\
\hline$A B$ Verpleging en verzorging & 60 & 5 & 26 & 5 & 5 \\
\hline BB Plantenteelt & 3 & 9 & 79 & 0 & 9 \\
\hline BB Bloemschikken & 13 & 8 & 73 & 2 & 4 \\
\hline BB Dierverzorging en veterinaire ondersteuning & 44 & 0 & 13 & 13 & 29 \\
\hline BB Groene ruimte & 0 & 25 & 71 & 4 & 0 \\
\hline BB Houtbewerking en woninginrichting & 26 & 16 & 47 & 7 & 4 \\
\hline BB Reclame, presentatie en communicatie & 61 & 0 & 32 & 3 & 3 \\
\hline BB Motorvoertuigen & 6 & 44 & 44 & 6 & 0 \\
\hline BB Graf. techn, communicatie, audiovisueel en multimedia & 14 & 0 & 68 & 9 & 9 \\
\hline BB Bedrijfsadministratie & 39 & 18 & 39 & 4 & 0 \\
\hline BB Secretarieel & 42 & 12 & 37 & 0 & 8 \\
\hline BB Detailhandel/ambulante handel & 28 & 9 & 51 & 0 & 12 \\
\hline BB Horeca, instellingskeuken en contractcatering & 28 & 35 & 30 & 6 & 1 \\
\hline BB Facilitaire dienstverlening & 19 & 0 & 74 & 0 & 8 \\
\hline BB Verpleging en verzorging & 44 & 15 & 39 & 1 & 1 \\
\hline \multicolumn{6}{|l|}{ BOL niveau $3 / 4$} \\
\hline ZB Plantenteelt & 11 & 14 & 67 & 2 & 5 \\
\hline ZB Veehouderij & 16 & 12 & 66 & 0 & 5 \\
\hline ZB Levensmiddelentechnologie & 26 & 15 & 59 & 0 & 0 \\
\hline ZB Bloemschikken & 18 & 6 & 67 & 2 & 7 \\
\hline ZB Dierverzorging en veterinaire ondersteuning & 24 & 8 & 56 & 3 & 9 \\
\hline ZB Paardenhouderij en paardensport & 12 & 11 & 61 & 5 & 11 \\
\hline ZB Groene ruimte & 15 & 12 & 67 & 3 & 2 \\
\hline ZB Werktuigbouwkunde & 56 & 0 & 44 & 0 & 0 \\
\hline ZB Graf. techn, communicatie, audiovisueel en multimedia & 11 & 0 & 83 & 6 & 0 \\
\hline ZB Scheepvaart & 10 & 4 & 86 & 0 & 0 \\
\hline ZB Bedrijfsadministratief & 35 & 3 & 61 & 0 & 0 \\
\hline ZB Detailhandel/ambulante handel & 46 & 0 & 46 & 0 & 8 \\
\hline ZB Groothandel/distributie & 64 & 0 & 32 & 0 & 5 \\
\hline ZB Toerisme, recreatie en reizen & 21 & 1 & 67 & 10 & 0 \\
\hline ZB Verpleging en verzorging & 16 & 13 & 68 & 0 & 3 \\
\hline ZB Uiterlijke verzorging & 20 & 3 & 73 & 3 & 1 \\
\hline KF Plantenteelt & 50 & 2 & 42 & 0 & 6 \\
\hline KF Veehouderij & 42 & 4 & 49 & 2 & 3 \\
\hline KF Levensmiddelentechnologie & 42 & 4 & 49 & 0 & 4 \\
\hline KF Bloemschikken & 17 & 8 & 73 & 0 & \\
\hline
\end{tabular}


Tabel B1.3 (vervolg)

Bestemming van schoolverlaters

\begin{tabular}{|c|c|c|c|c|c|}
\hline Opleidingsrichting & $\begin{array}{r}\text { studie } \\
\%\end{array}$ & $\begin{array}{r}\text { BBL } \\
\%\end{array}$ & $\begin{array}{r}\text { betaald } \\
\text { werk } \\
\%\end{array}$ & $\begin{array}{r}\text { werk- } \\
\text { loos } \\
\%\end{array}$ & $\begin{array}{r}\text { anders } \\
\%\end{array}$ \\
\hline KF Dierverzorging en veterinaire ondersteuning & 35 & 2 & 61 & 3 & 0 \\
\hline KF Paardenhouderij en paardensport & 25 & 4 & 67 & 0 & 4 \\
\hline KF Groene ruimte & 47 & 4 & 46 & 2 & 1 \\
\hline KF Milieutoezicht & 70 & 2 & 25 & 0 & 3 \\
\hline MKF Bouw & 57 & 1 & 39 & 2 & 1 \\
\hline MKF Houtbewerking en woninginrichting & 25 & 2 & 67 & 2 & 4 \\
\hline MKF Grond-, water- en wegenbouw & 41 & 2 & 53 & 4 & 0 \\
\hline MKF Beschermings- en afwerkingstechnieken & 20 & 6 & 68 & 5 & 0 \\
\hline MKF Reclame, presentatie en communicatie & 44 & 2 & 50 & 3 & 1 \\
\hline MKF Operationele techniek & 18 & 0 & 82 & 0 & 0 \\
\hline MKF Werktuigbouwkunde & 60 & 2 & 35 & 2 & 2 \\
\hline MKF Motorvoertuigen & 40 & 10 & 50 & 0 & 0 \\
\hline MKF Energie- en informatietechniek & 65 & 2 & 31 & 2 & 0 \\
\hline MKF Energietechniek & 47 & 0 & 53 & 0 & 0 \\
\hline MKF Informatietechniek & 60 & 4 & 33 & 2 & 1 \\
\hline MKF Graf. techn, communicatie, audiovisueel en multimedia & 23 & 0 & 60 & 9 & 8 \\
\hline MKF Laboratoriumtechniek & 52 & 3 & 42 & 4 & 0 \\
\hline MKF Procestechniek & 59 & 0 & 41 & 0 & 0 \\
\hline MKF Scheepvaart & 32 & 0 & 58 & 0 & 10 \\
\hline MKF Transport en logistiek & 29 & 2 & 66 & 0 & 2 \\
\hline MKF Automatisering & 48 & 0 & 49 & 3 & 0 \\
\hline MKF Bedrijfsadministratief & 51 & 14 & 30 & 1 & 4 \\
\hline MKF Commercieel & 53 & 2 & 42 & 3 & 0 \\
\hline MKF Economisch-juridisch & 55 & 8 & 28 & 9 & 0 \\
\hline MKF Secretarieel & 37 & 2 & 60 & 0 & 1 \\
\hline MKF Detailhandel/ambulante handel & 47 & 3 & 45 & 1 & 4 \\
\hline MKF Groothandel/distributie & 78 & 0 & 22 & 0 & 0 \\
\hline MKF Horeca, instellingskeuken en contractcatering & 35 & 2 & 62 & 1 & 1 \\
\hline MKF Toerisme, recreatie en reizen & 33 & 1 & 62 & 4 & 1 \\
\hline MKF Assistenten gezondheidszorg & 21 & 3 & 71 & 0 & 5 \\
\hline MKF Facilitaire dienstverlening & 35 & 6 & 59 & 0 & 0 \\
\hline MKF Sport en bewegen & 48 & 5 & 43 & 1 & 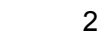 \\
\hline MKF Verpleging en verzorging & 24 & 6 & 70 & 0 & 0 \\
\hline MKF Maatschappelijke dienstverlening & 63 & 5 & 33 & 0 & 0 \\
\hline MKF Sociaal-pedagogisch werk algemeen & 45 & 5 & 46 & 1 & \\
\hline MKF Sociaal-juridisch werk & 45 & 15 & 38 & 2 & 0 \\
\hline
\end{tabular}

BBL niveau $1 / 2$

AB Groene ruimte

$A B$ Beveiliging

$A B$ Detailhandel/ambulante handel

$A B$ Verpleging en verzorging

BB Plantenteelt

BB Bloemschikken

BB Groene ruimte

BB Bouw

BB Houtbewerking en woninginrichting

BB Grond-, water en wegenbouw

BB Beschermings- en afwerkingstechnieken

BB Constructie-, plaatwerken/pijpenbewerken

BB Montage/onderhoud/operationele techniek

BB Motorvoertuigen

BB Energie- en informatietechniek

BB Energietechniek

BB Installatie-, service- en onderhoudstechniek

BB Procestechniek

BB Wegvervoer

BB Detailhandel/ambulante handel

$\begin{array}{rrr}80 & 3 & 0 \\ 93 & 4 & 0 \\ 63 & 10 & 3 \\ 65 & 0 & 10 \\ 75 & 2 & 2 \\ 64 & 4 & 0 \\ 75 & 0 & 0 \\ 64 & 3 & 3 \\ 69 & 4 & 0 \\ 57 & 14 & 0 \\ 75 & 0 & 0 \\ 67 & 2 & 2 \\ 73 & 0 & 0 \\ 58 & 0 & 2 \\ 63 & 0 & 0 \\ 66 & 6 & 0 \\ 50 & 3 & 0 \\ 95 & 4 & 0 \\ 99 & 0 & 0 \\ 83 & 3 & 4\end{array}$


Tabel B1.3 (vervolg)

Bestemming van schoolverlaters

\begin{tabular}{|c|c|c|c|c|c|}
\hline Opleidingsrichting & $\begin{array}{r}\text { studie } \\
\%\end{array}$ & $\begin{array}{r}\text { BBL } \\
\%\end{array}$ & $\begin{array}{r}\text { betaald } \\
\text { werk } \\
\%\end{array}$ & $\begin{array}{r}\text { werk- } \\
\text { loos } \\
\%\end{array}$ & $\begin{array}{r}\text { anders } \\
\%\end{array}$ \\
\hline
\end{tabular}

BBL niveau 1/2 (vervolg)

BB Opslag/magazijn

BB Horeca, instellingskeuken en contractcatering

BB Facilitaire dienstverlening

$B B$ Verpleging en verzorging

BB Uiterlijke verzorging

$\begin{array}{rrrrr}0 & 11 & 81 & 8 & 0 \\ 5 & 39 & 54 & 0 & 2 \\ 0 & 5 & 90 & 0 & 5 \\ 2 & 24 & 70 & 1 & 3 \\ 0 & 0 & 100 & 0 & 0\end{array}$

BBL niveau $3 / 4$

ZB Plantenteelt

ZB Bloemschikken

ZB Groene ruimte

ZB Bouw

ZB Grond-, water- en wegenbouw

ZB Constructie-, plaatwerken/pijpenbewerken

ZB Motorvoertuigen

ZB Energie- en informatietechniek

ZB Energietechniek

ZB Beheer, ontwerp en management (instal. techn)

ZB Installatie-, service- en onderhoudstechniek

ZB Procestechniek

ZB Automatisering

ZB Detailhandel/ambulante handel

ZB Opslag/magazijn

ZB Horeca, instellingskeuken en contractcatering

ZB Verpleging en verzorging

ZB Uiterlijke verzorging

MKF Bouw

MKF Detailhandel/ambulante handel

MKF Horeca, instellingskeuken en contractcatering

MKF Verpleging en verzorging

MKF Sociaal-pedagogisch werk

Specialist Energietechniek

Specialist Verpleging en verzorging

$\begin{array}{rrrll}13 & 0 & 87 & 0 & 0 \\ 3 & 4 & 85 & 1 & 7 \\ 9 & 5 & 85 & 0 & 0 \\ 5 & 7 & 87 & 0 & 1 \\ 0 & 5 & 87 & 3 & 5 \\ 7 & 3 & 87 & 3 & 0 \\ 0 & 5 & 95 & 0 & 0 \\ 0 & 6 & 93 & 0 & 1 \\ 11 & 16 & 74 & 0 & 0 \\ 0 & 5 & 95 & 0 & 0 \\ 0 & 17 & 81 & 0 & 1 \\ 0 & 4 & 91 & 4 & 0 \\ 14 & 0 & 77 & 9 & 0 \\ 2 & 5 & 86 & 5 & 2 \\ 6 & 0 & 87 & 6 & 0 \\ 2 & 2 & 94 & 0 & 2 \\ 0 & 9 & 87 & 0 & 4 \\ 4 & 0 & 93 & 0 & 2 \\ 6 & 6 & 81 & 0 & 6 \\ 12 & 6 & 81 & 0 & 0 \\ 6 & 13 & 75 & 0 & 6 \\ 6 & 3 & 91 & 0 & 0 \\ 1 & 0 & 97 & 1 & 1 \\ 4 & 0 & 95 & 1 & 0 \\ 0 & 0 & 100 & 0 & 0\end{array}$


Tabel B1.4

Gevolgde opleiding opnieuw kiezen?

\begin{tabular}{|c|c|c|c|}
\hline Opleidingsrichting & $\begin{array}{r}\text { zelfde } \\
\text { opleiding } \\
\%\end{array}$ & $\begin{array}{r}\text { andere } \\
\text { opleiding } \\
\%\end{array}$ & $\begin{array}{r}\text { geen andere } \\
\text { opleiding } \\
\%\end{array}$ \\
\hline
\end{tabular}

BOL niveau $1 / 2$

$A B$ Motorvoertuigen

$A B$ Beveiliging

AB Secretarieel

$A B$ Verpleging en verzorging

BB Plantenteelt

BB Bloemschikken

BB Dierverzorging en veterinaire ondersteuning

BB Groene ruimte

BB Houtbewerking en woninginrichting

BB Reclame, presentatie en communicatie

BB Motorvoertuigen

BB Graf. techn, communicatie, audiovisueel en multimedia

BB Bedrijfsadministratie

BB Secretarieel

BB Detailhandel/ambulante hande

BB Horeca, instellingskeuken en contractcatering

BB Facilitaire dienstverlening

$B B$ Verpleging en verzorging

$\begin{array}{rrr}76 & 12 & 12 \\ 68 & 25 & 7 \\ 80 & 7 & 13 \\ 74 & 20 & 6 \\ 56 & 26 & 18 \\ 58 & 6 & 36 \\ 67 & 20 & 13 \\ 79 & 13 & 8 \\ 68 & 22 & 10 \\ 72 & 28 & 0 \\ 81 & 6 & 13 \\ 73 & 14 & 14 \\ 81 & 15 & 4 \\ 57 & 39 & 4 \\ 56 & 28 & 16 \\ 72 & 24 & 4 \\ 50 & 35 & 16 \\ 58 & 35 & 7\end{array}$

BOL niveau 3/4

ZB Plantenteelt

ZB Veehouderij

ZB Levensmiddelentechnologie

ZB Bloemschikken

ZB Dierverzorging en veterinaire ondersteuning

ZB Paardenhouderij en paardensport

ZB Groene ruimte

ZB Werktuigbouwkunde

ZB Graf. techn, communicatie, audiovisueel en multimedia

ZB Scheepvaart

ZB Bedrijfsadministratief

ZB Detailhandel/ambulante handel

ZB Groothandel/distributie

ZB Toerisme, recreatie en reizen

$Z B$ Verpleging en verzorging

ZB Uiterlijke verzorging

KF Plantenteelt

KF Veehouderi

KF Levensmiddelentechnologie

KF Bloemschikken

KF Dierverzorging en veterinaire ondersteuning

KF Paardenhouderij en paardensport

KF Groene ruimte

KF Milieutoezicht

MKF Bouw

MKF Houtbewerking en woninginrichting

MKF Grond-, water- en wegenbouw

MKF Beschermings- en afwerkingstechnieken

MKF Reclame, presentatie en communicatie

MKF Operationele techniek

MKF Werktuigbouwkunde

MKF Motorvoertuigen

MKF Energie- en informatietechniek

MKF Energietechniek

MKF Informatietechniek

MKF Graf. techn, communicatie, audiovisueel en multimedia

$\begin{array}{rrr}65 & 26 & 9 \\ 75 & 15 & 10 \\ 76 & 24 & 0 \\ 64 & 26 & 10 \\ 58 & 32 & 10 \\ 36 & 58 & 6 \\ 61 & 28 & 11 \\ 94 & 6 & 0 \\ 78 & 22 & 0 \\ 77 & 19 & 4 \\ 73 & 27 & 0 \\ 76 & 24 & 0 \\ 86 & 14 & 0 \\ 68 & 31 & 1 \\ 71 & 26 & 3 \\ 77 & 23 & 0 \\ 73 & 23 & 3 \\ 73 & 25 & 2 \\ 64 & 34 & 2 \\ 70 & 22 & 8 \\ 80 & 15 & 5 \\ 58 & 42 & 0 \\ 71 & 26 & 4 \\ 65 & 30 & 5 \\ 86 & 12 & 2 \\ 79 & 19 & 2 \\ 94 & 4 & 2 \\ 68 & 30 & 2 \\ 85 & 13 & 2 \\ 88 & 12 & 0 \\ 85 & 11 & 3 \\ 80 & 17 & 3 \\ 83 & 15 & 2 \\ 79 & 21 & 0 \\ 88 & 12 & 1 \\ 75 & 25 & 0\end{array}$


Tabel B1.4 (vervolg)

Gevolgde opleiding opnieuw kiezen?

\begin{tabular}{lrrr}
\hline Opleidingsrichting & $\begin{array}{r}\text { zelfde } \\
\text { opleiding } \\
\%\end{array}$ & $\begin{array}{r}\text { andere } \\
\text { opleiding } \\
\%\end{array}$ & $\begin{array}{r}\text { geen andere } \\
\text { opleiding } \\
\%\end{array}$
\end{tabular}

BOL niveau 3/4 (vervolg)

MKF Laboratoriumtechniek

MKF Procestechniek

MKF Scheepvaart

MKF Transport en logistiek

MKF Automatisering

MKF Bedrijfsadministratief

MKF Commercieel

MKF Economisch-juridisch

MKF Secretarieel

MKF Detailhandel/ambulante handel

MKF Groothandel/distributie

MKF Horeca, instellingskeuken en contractcatering

MKF Toerisme, recreatie en reizen

MKF Assistenten gezondheidszorg

MKF Facilitaire dienstverlening

MKF Sport en bewegen

MKF Verpleging en verzorging

MKF Maatschappelijke dienstverlening

MKF Sociaal-pedagogisch werk algemeen

MKF Sociaal-juridisch werk

$\begin{array}{lrl}77 & 23 & 0 \\ 62 & 38 & 0 \\ 82 & 18 & 0 \\ 88 & 9 & 4 \\ 66 & 34 & 0 \\ 82 & 16 & 2 \\ 71 & 28 & 1 \\ 61 & 34 & 5 \\ 67 & 30 & 4 \\ 67 & 30 & 3 \\ 63 & 33 & 4 \\ 84 & 15 & 1 \\ 74 & 25 & 1 \\ 78 & 19 & 3 \\ 72 & 28 & 0 \\ 94 & 5 & 1 \\ 66 & 33 & 1 \\ 82 & 18 & 0 \\ 85 & 13 & 2 \\ 85 & 13 & 2\end{array}$

$B B L$ niveau $1 / 2$

AB Groene ruimte

$A B$ Beveiliging

AB Detailhandel/ambulante handel

$A B$ Verpleging en verzorging

BB Plantenteelt

BB Bloemschikken

BB Groene ruimte

BB Bouw

BB Houtbewerking en woninginrichting

BB Grond-, water en wegenbouw

BB Beschermings- en afwerkingstechnieken

BB Constructie-, plaatwerken/pijpenbewerken

BB Montage/onderhoud/operationele techniek

BB Motorvoertuigen

BB Energie- en informatietechniek

BB Energietechniek

BB Installatie-, service- en onderhoudstechniek

BB Procestechniek

BB Wegvervoer

BB Detailhandel/ambulante handel

BB Opslag/magazijn

BB Horeca, instellingskeuken en contractcatering

BB Facilitaire dienstverlening

$B B$ Verpleging en verzorging

BB Uiterlijke verzorging

BBL niveau $3 / 4$

ZB Plantenteelt

ZB Bloemschikken

ZB Groene ruimte 
Tabel B1.4 (vervolg)

Gevolgde opleiding opnieuw kiezen?

Opleidingsrichting

$\begin{array}{rrr}\text { zelfde } & \text { andere } & \text { geen andere } \\ \text { opleiding } & \text { opleiding } & \text { opleiding } \\ \% & \% & \%\end{array}$

$B B L$ niveau 1/2 (vervolg)

ZB Beheer, ontwerp en management (instal. techn)

ZB Installatie-, service- en onderhoudstechniek

ZB Procestechniek

87

ZB Automatisering

ZB Detailhandel/ambulante handel

ZB Opslag/magazijn

ZB Horeca, instellingskeuken en contractcatering

$Z B$ Verpleging en verzorging

ZB Uiterlijke verzorging

MKF Bouw

MKF Detailhandel/ambulante handel

MKF Horeca, instellingskeuken en contractcatering

MKF Verpleging en verzorging

MKF Sociaal-pedagogisch werk

Specialist Energietechniek

Specialist Verpleging en verzorging

$\begin{array}{rr}11 & 0 \\ 10 & 7 \\ 9 & 4 \\ 23 & 0 \\ 30 & 10 \\ 0 & 27 \\ 22 & 9 \\ 17 & 2 \\ 5 & 0 \\ 6 & 12 \\ 23 & 5 \\ 19 & 0 \\ 18 & 0 \\ 15 & 1 \\ 8 & 5 \\ 15 & 0\end{array}$


Tabel B2.1

Doorstroom van schoolverlaters naar het vervolgonderwijs

\begin{tabular}{|c|c|c|c|c|c|c|c|c|}
\hline Opleidingsrichting & $\begin{array}{r}\text { verder } \\
\text { leren } \\
\%\end{array}$ & $\begin{array}{r}\text { MAVO } \\
\%\end{array}$ & $\begin{array}{r}\text { HAVO } \\
\%\end{array}$ & $\begin{array}{r}\text { VBO } \\
\%\end{array}$ & $\begin{array}{r}\text { BOL } \\
\text { niv. } 1 / 2 \\
\%\end{array}$ & $\begin{array}{r}\text { BOL } \\
\text { niv. } 3 / 4 \\
\%\end{array}$ & $\begin{array}{r}\text { BBL } \\
\text { niv. } 1 / 2 \\
\%\end{array}$ & $\begin{array}{r}\text { BBL } \\
\text { niv. } 3 / 4 \\
\%\end{array}$ \\
\hline
\end{tabular}

VBO

IVBO Landbouw en natuurlijke omgeving

IVBO Verzorging

Landbouw en natuurlijke omgeving

Bouwtechniek

Mechanische techniek

Elektrotechniek

Motorvoertuigentechniek

Consumptieve techniek

Nautische opleidingen

Administratie

Verkoop

Verzorging

Uiterlijke verzorging

$\begin{array}{ll}68 & \\ 83 & 0 \\ 81 & \\ 86 & \\ 80 & \\ 80 & \\ 80 & \\ 76 & 0 \\ 84 & 0 \\ 86 & \\ 83 & 0 \\ 82 & 0 \\ 77 & 0\end{array}$

\section{BOL niveau $1 / 2$}

$A B$ Bever

BB Detailhandel/ambulante handel

BB Horeca, instellingskeuken en contractcatering

BB Verpleging en verzorging

\section{BOL niveau 3/4}

ZB Plantenteelt

ZB Veehouderij

ZB Bloemschikken

ZB Dierverzorging en veterinaire ondersteuning

ZB Groene ruimte

ZB Groothandel/distributie

ZB Verpleging en verzorging

KF Plantenteelt

0
0
1
0
4
0
0
0
0
0
0
0
3

$\begin{array}{lll}0 & 1 & 29 \\ 0 & 0 & 50 \\ 0 & 0 & 14 \\ 0 & 2 & 10 \\ 0 & 0 & \\ 0 & 0 & 11 \\ 0 & 0 & 15 \\ 0 & 0 & 27 \\ 0 & 0 & \\ 2 & 0 & 44 \\ 0 & 0 & 35 \\ 0 & 0 & 22 \\ 3 & 0 & \end{array}$

$\begin{array}{rrr}29 & 23 & 35 \\ 50 & 6 & 39 \\ 14 & 58 & 16 \\ 10 & 23 & 58 \\ 7 & 37 & 33 \\ 11 & 62 & 19 \\ 15 & 35 & 35 \\ 27 & 4 & 5 \\ 0 & 29 & \\ 44 & 44 & \\ 35 & 32 & 21 \\ 22 & 57 & \\ 11 & 32 & \\ & & \end{array}$

$\begin{array}{rrr}35 & 11 & 0 \\ 39 & 6 & 0 \\ 16 & 12 & 0 \\ 58 & 6 & 0 \\ 33 & 19 & 0 \\ 19 & 8 & 0 \\ 35 & 15 & 0 \\ 50 & 19 & 0 \\ 0 & 71 & 0 \\ 7 & 4 & 0 \\ 21 & 12 & 0 \\ 9 & 12 & 0 \\ 23 & 27 & 0 \\ & & \end{array}$

\begin{tabular}{|c|c|c|c|c|c|c|c|}
\hline 18 & 0 & 0 & 0 & 23 & 62 & 0 & 8 \\
\hline 34 & 0 & 0 & 0 & 0 & 57 & $c$ & 43 \\
\hline 61 & 0 & 0 & 0 & 2 & 23 & 2 & 73 \\
\hline 57 & 0 & 0 & 0 & 1 & 61 & 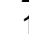 & 35 \\
\hline
\end{tabular}

$\begin{array}{llll}28 & 0 & 0 & 0 \\ 26 & 0 & 0 & 0 \\ 30 & 0 & 0 & 0 \\ 27 & 0 & 0 & 0 \\ 31 & 0 & 0 & 0 \\ 68 & 0 & 0 & 0 \\ 33 & 0 & 0 & 0 \\ 52 & 0 & 0 & 0\end{array}$

$\begin{array}{rr}0 & 35 \\ 14 & 47 \\ 0 & 44 \\ 17 & 77 \\ 14 & 52 \\ 0 & 8 \\ 0 & 54 \\ 2 & 9\end{array}$

26
0
0
6
5
0
2
0

$\begin{array}{rr}39 & 0 \\ 13 & 26 \\ 56 & 0 \\ 0 & 0 \\ 19 & 10 \\ 0 & 92 \\ 44 & 0 \\ 2 & 87\end{array}$


Tabel B2.1 (vervolg)

Doorstroom van schoolverlaters naar het vervolgonderwijs

\begin{tabular}{|c|c|c|c|c|c|c|c|c|c|}
\hline Opleidingsrichting & $\begin{array}{r}\text { verder } \\
\text { leren } \\
\%\end{array}$ & $\begin{array}{r}\text { MAVO } \\
\%\end{array}$ & $\begin{array}{r}\text { HAVO } \\
\%\end{array}$ & $\begin{array}{r}\text { VBO } \\
\%\end{array}$ & $\begin{array}{r}\mathrm{BOL} \\
\text { niv. } 1 / 2 \\
\%\end{array}$ & $\begin{array}{r}\text { BOL } \\
\text { niv. } 3 / 4 \\
\%\end{array}$ & $\begin{array}{r}\text { BBL } \\
\text { niv. } 1 / 2 \\
\%\end{array}$ & $\begin{array}{r}\text { BBL } \\
\text { niv. } 3 / 4 \\
\%\end{array}$ & $\begin{array}{r}\mathrm{HBO} \\
\%\end{array}$ \\
\hline
\end{tabular}

BOL niveau 3/4 (vervolg)

KF Veehouderi

KF Levensmiddelentechnologie

KF Dierverzorging en veterinaire ondersteuning

KF Groene ruimte

KF Milieutoezicht

MKF Bouw

MKF Houtbewerking en woninginrichting

MKF Grond-, water- en wegenbouw

MKF Beschermings- en afwerkingstechnieken

MKF Reclame, presentatie en communicatie

MKF Werktuigbouwkunde

MKF Motorvoertuigen

MKF Energie- en informatietechniek

MKF Informatietechniek

MKF Laboratoriumtechniek

MKF Transport en logistiek

MKF Bedrijfsadministratie

MKF Commercieel

MKF Economisch-juridisch

MKF Secretarieel

MKF Detailhandel/ambulante hande

MKF Groothandel/distributie

MKF Horeca, instellingskeuken en contractcatering

MKF Toerisme, recreatie en reizen

MKF Assistenten gezondheidszorg

MKF Sport en bewegen

MKF Verpleging en verzorging

MKF Maatschappelijke dienstverlening

MKF Sociaal-pedagogisch werk algemeen

MKF Sociaal-juridisch werk

$\begin{array}{rrrrrrrrr}46 & 0 & 0 & 0 & 0 & 12 & 1 & 1 & 86 \\ 48 & 0 & 0 & 0 & 0 & 4 & 5 & 5 & 85 \\ 37 & 0 & 0 & 0 & 0 & 22 & 0 & 0 & 78 \\ 51 & 0 & 0 & 0 & 0 & 9 & 3 & 1 & 87 \\ 68 & 0 & 0 & 0 & 0 & 15 & 0 & 0 & 85 \\ 59 & 0 & 0 & 0 & 0 & 4 & 2 & 0 & 93 \\ 22 & 0 & 0 & 0 & 3 & 8 & 0 & 0 & 78 \\ 45 & 0 & 0 & 0 & 0 & 0 & 0 & 0 & 100 \\ 32 & 0 & 0 & 0 & 0 & 11 & 6 & 23 & 52 \\ 44 & 0 & 0 & 0 & 0 & 4 & 0 & 0 & 94 \\ 63 & 0 & 0 & 0 & 0 & 8 & 0 & 3 & 89 \\ 57 & 0 & 0 & 0 & 0 & 7 & 0 & 13 & 80 \\ 69 & 0 & 0 & 0 & 0 & 9 & 0 & 0 & 91 \\ 68 & 0 & 0 & 0 & 0 & 4 & 0 & 0 & 96 \\ 53 & 0 & 0 & 0 & 0 & 0 & 0 & 5 & 93 \\ 37 & 0 & 0 & 3 & 0 & 14 & 0 & 0 & 83 \\ 62 & 0 & 0 & 0 & 0 & 2 & 0 & 0 & 97 \\ 50 & 0 & 0 & 2 & 0 & 4 & 0 & 0 & 94 \\ 59 & 0 & 0 & 0 & 0 & 0 & 0 & 0 & 93 \\ 35 & 0 & 0 & 0 & 0 & 0 & 0 & 3 & 97 \\ 57 & 0 & 0 & 0 & 0 & 12 & 0 & 4 & 82 \\ 76 & 0 & 0 & 0 & 0 & 25 & 0 & 0 & 75 \\ 36 & 0 & 0 & 0 & 0 & 4 & 0 & 0 & 96 \\ 34 & 0 & 0 & 0 & 0 & 1 & 0 & 0 & 99 \\ 23 & 0 & 0 & 0 & 0 & 4 & 2 & 14 & 79 \\ 47 & 0 & 0 & 0 & 0 & 0 & 2 & 0 & 98 \\ 27 & 0 & 0 & 0 & 0 & 0 & 0 & 6 & 94 \\ 69 & 0 & 0 & 0 & 0 & 0 & 0 & 10 & 90 \\ 52 & 0 & 0 & 0 & 0 & 5 & 0 & 1 & 93 \\ 72 & 0 & 0 & 0 & 0 & 6 & 0 & 3 & 91\end{array}$


Tabel B2.1 (vervolg)

Doorstroom van schoolverlaters naar het vervolgonderwijs

\begin{tabular}{|c|c|c|c|c|c|c|c|c|c|}
\hline Opleidingsrichting & $\begin{array}{r}\text { verder } \\
\text { leren } \\
\%\end{array}$ & $\begin{array}{r}\text { MAVO } \\
\%\end{array}$ & $\begin{array}{r}\text { HAVO } \\
\%\end{array}$ & $\begin{array}{r}\text { VBO } \\
\%\end{array}$ & $\begin{array}{r}\text { BOL } \\
\text { niv. } 1 / 2 \\
\%\end{array}$ & $\begin{array}{r}\text { BOL } \\
\text { niv. } 3 / 4 \\
\%\end{array}$ & $\begin{array}{r}\text { BBL } \\
\text { niv. } 1 / 2 \\
\%\end{array}$ & $\begin{array}{r}\text { BBL } \\
\text { niv. } 3 / 4 \\
\%\end{array}$ & $\mathrm{HBO}$ \\
\hline
\end{tabular}

BBL niveau $1 / 2$

BB Bloemschi

BB Groene ruimte

BB Bouw

BB Houtbewerking en woninginrichting

BB Motorvoertuigen

BB Energietechniek
BB Installatie-, service- en onderhoudstechniek

BB Horeca, instellingskeuken en contractcatering

BB Verpleging en verzorging

36
28
42
49
36
42
70
36
32

BBL niveau $3 / 4$

ZB Groene ruimte

ZB Bouw

ZB Installatie-, service- en onderhoudstechniek

ZB Verpleging en verzorging

$\begin{array}{lll}0 & 0 & 0 \\ 0 & 0 & 0 \\ 0 & 0 & 6 \\ 0 & 0 & 0 \\ 0 & 0 & 0 \\ 0 & 0 & 0 \\ 0 & 0 & 0 \\ 0 & 0 & 0 \\ 0 & 0 & 0\end{array}$

$\begin{array}{rrrrrl}0 & 0 & 10 & 5 & 85 & 0 \\ 0 & 7 & 17 & 0 & 77 & 0 \\ 6 & 0 & 0 & 2 & 87 & 6 \\ 0 & 12 & 12 & 0 & 76 & 0 \\ 0 & 0 & 7 & 7 & 87 & 0 \\ 0 & 0 & 13 & 13 & 75 & 0 \\ 0 & 2 & 2 & 25 & 71 & 0 \\ 0 & 0 & 0 & 0 & 100 & 0 \\ 0 & 0 & 7 & 3 & 83 & 0\end{array}$

\begin{tabular}{rrrrrrrrr}
27 & 0 & 0 & 0 & 0 & 15 & 0 & 35 & 51 \\
18 & 0 & 0 & 0 & 0 & 0 & 7 & 59 & 34 \\
33 & 0 & 0 & 0 & 0 & 5 & 0 & 95 & 0 \\
13 & 0 & 0 & 0 & 0 & 8 & 4 & 84 & 4 \\
\hline
\end{tabular}


Tabel B2.2

Belangrijkste opleidingen van schoolverlaters die een vervolgopleiding zijn gaan volgen

\section{IVBO Verzorging}

BOL BB Helpende (verpleging en verzorging) $\quad 32$

BBL BB Helpende (verpleging en verzorging) 21

BOL AB Horeca-assistant

BOL BB Bedrijfsadministratie

BOL BB Verpleging en verzorging

BOL ZB Bedrijfsadministratief

BBL BB Facilitaire dienstverlening

BBL BB Voedingsassistent

BBL BB Bejaardenhelpende

BBL KF Bloemschikken

VBO Landbouw en natuurlijke omgeving

BOL ZB Sociaal-pedagogisch werk

VBO Bouwtechniek

BBL BB Primaire timmerkracht

BOL MKF Bouwkunde

BBL BB Meubelmaker/interieurbouwer/scheepsinterieurbouwer

VBO Mechanische techniek

BOL MKF Werktuigbouwkunde

VBO Elektrotechniek

BOL MKF Techniek

BBL BB Monteur sterkstroominstallaties

10

BOL MKF Elektrotechnische installatietechniek

BOL Specialist Technicus informatie-communicatie technologie

VBO Motorvoertuigentechniek

BBL BB Autotechnicus

BOL MKF Motorvoertuigen

BOL MKF Bedrijfsmanagement motorvoertuigen

BBL AB Assistent autotechnicus

BBL BB Autoschadehersteller

BBL BB Chauffeur goederenvervoer

VBO Consumptieve techniek

BBL BB Kok

BOL BB Kok

BBL BB Gastheer/-vrouw

BBL ZB Zelfstandig werkend kok

BOL BB Gastheer/-vrouw

VBO Nautische opleidingen

BBL ZB Stuurman/schipper

VBO Administratie

BOL BB Secretariee

BOL BB Commercieel administratief medewerker

\section{VBO Verkoop}

BOL BB Detailhandel/ambulante handel

BOL BB Bedrijfsadministratie

BOL BB Verkoopmedewerker

BOL MKF Ondernemer/manager detailhandel

BOL MKF Doktersassistent 
Tabel B2.2 (vervolg)

Belangrijkste opleidingen van schoolverlaters die een vervolgopleiding zijn gaan volgen

VBO Verkoop (vervolg)

BOL MKF Apothekersassistent

VBO Verzorging

BOL ZB Sociaal-pedagogisch werk

17

$B O L$ BB Helpende (verpleging en verzorging)

BOL ZB Verzorgende

BOL MKF Sociaal-pedagogisch werker

BBL ZB Verzorgende

VBO Uiterlijke verzorging

BBL ZB All-round kapper

BBL BB Kapper

BOL ZB Schoonheidsspecialist

$\mathrm{BOL} B \mathrm{BB}$ Helpende (verpleging en verzorging)

BOL ZB All-round kapper

BOL ZB Sociaal-pedagogisch werk

$B B L A B$ Administratief medewerker

BOL AB Beveiliging

BOL ZB Sociaal dienstverlener

BOL MKF Sport en bewegen

BOL BB Servicemedewerker ICT

BOL BB Beveiliging

BOL BB Beveiligingsmedewerker

BOL MKF Administratief-juridisch medewerker - openbaar bestuur

BOL MKF Internationaal secretariaat (IS)

BOL MKF Groothandel/distributie

BOL MKF Sociaal-juridisch werk

BBL ZB Sociaal-pedagogisch werk

HBO KMA-officier landmacht

BOL BB Detailhandel/ambulante handel

BOL MKF Detailhandel/ambulante handel

BOL MKF Filiaalbeheerder

BBL ZB Eerste verkoper

BBL MKF Ondernemer/manager detailhandel

BOL ZB Groothandel/distributie

BOL MKF Ondernemer/manager detailhandel

BOL MKF Sociaal-pedagogisch werk

BOL MKF Onderwijsassistent

BBL ZB Verkoopchef

BBL MKF Detailhandel/ambulante handel

BOL BB Horeca, instellingskeuken en contractcatering

BBL ZB Zelfstandig werkend kok

BOL BB Verpleging en verzorging

BOL ZB Sociaal-pedagogisch werk

$B O L$ ZB Verzorgende

$B B L Z B$ Verzorgende

$B B L$ ZB Verzorgende bij inst. voor gezinsverz.

BOL MKF Sociaal-pedagogisch werk

BOL ZB Plantenteelt

BBL BB Monteur landbouwmechanisatietechniek

BOL ZB Boomteelt

BOL MKF Landbouwtechniek 
Tabel B2.2 (vervolg)

Belangrijkste opleidingen van schoolverlaters die een vervolgopleiding zijn gaan volgen

BOL ZB Plantenteelt (vervolg)

BOL MKF Groothandel/distributie

BOL Specialist Techniek

BBL ZB Grond-, water- en wegenbouw

BBL ZB Machinist grondverzetmachines

BBL ZB Eerste monteur landbouwmechanisatietechniek

BBL ZB Eerste autotechnicus

BOL ZB Veehouderij

BOL KF Veehouderij

BOL KF Veehouderij en management

BOL BB Assistent-installatiemonteur

BBL KF Veehouderij

HBO Landbouw

HBO Sociaal pedagogische hulpverlening

BOL ZB Bloemschikken

BOL KF Bloemschikken

BBL Specialist Bloembinden

BOL ZB Dierverzorging en veterinaire ondersteuning

$\mathrm{BOL}$ KF Dierverzorging en veterinaire ondersteuning

BOL ZB Vakfunctionaris biotechniek

BOL BB Werkplaatstimmerman

BOL BB Dierverzorging

BOL ZB Dierenzorg

BOL ZB Paardenhouderij

BOL ZB Toerisme, recreatie en reizen

BOL KF Dierenzorg

BOL KF Paardenhouderij en management

BOL MKF Sociaal-pedagogisch werker

BBL BB Landbouw

BOL ZB Groene ruimte

BOL ZB Klein groen

\section{BOL ZB Groothandel/distributie}

HBO Commerciele economie

HBO International Business Studies (IBS)

BOL MKF Commercieel

HBO Kort Marketing management

HBO Bedrijfsinformatica

HBO Management, economie en recht

HBO Logistiek en economie

HBO Communicatie

$B O L$ ZB Verpleging en verzorging

BOL MKF Verpleegkundige

BOL KF Plantenteelt

HBO Agrarische bedrijfskunde

HBO Landbouw

12

HBO Tuinbouw

HBO Landbouw

HBO Commerciele economie 
Tabel B2.2 (vervolg)

Belangrijkste opleidingen van schoolverlaters die een vervolgopleiding zijn gaan volgen

BOL KF Veehouderij

HBO Agrarische bedrijfskunde $\quad 17$

HBO Landbouw $\quad 15$

HBO Veehouderij 11

HBO Landbouw $\quad 5$

HBO Diermanagement $\quad 5$

BOL KF Levensmiddelentechnologie

HBO Voeding en marketing

HBO Levensmiddelentechnologie

HBO Milieutechnologie (technische)

BBL BB Beveiligingsmedewerker

BBL KF Levensmiddelentechnologie

HBO Biotechnologie (landbouw)

HBO Opleiding tot verpleegkundige

BOL KF Dierverzorging en veterinaire ondersteuning HBO Diermanagement

BOL KF Groene ruimte

HBO Landbouw

HBO Tuin- en landschapsinrichting

HBO Plattelandsvernieuwing

HBO Land-, water- en milieubeheer

HBO Bos- en natuurbeheer

HBO Landbouw

HBO Docentenopleiding Agrarisch

BOL KF Milieutoezicht

HBO Milieukunde (agrarisch)

HBO Land-, water- en milieubeheer 17

BOL KF Land-, water- en milieubeheer

HBO Biologie en medisch laboratoriumonderzoek

BOL MKF Bouw

HBO Bouwkunde

BOL MKF Houtbewerking en woninginrichting

HBO Taal en cultuur

HBO 2e fase Interieurarchitectuur

HBO Technische bedrijfskunde

HBO Management, economie en recht

HBO Beeldende kunst en vormgeving - vrij

BOL MKF Grond-, water- en wegenbouw

HBO Civiele techniek

HBO Ruimtelijke ordening en planologie

BOL MKF Beschermings- en afwerkingstechnieken

HBO Management, economie en recht

BBL ZB Eerste autoschadehersteller

HBO Kort Natuurwetenschappen

HBO Technische bedrijfskunde

HBO Taal en cultuur

$\mathrm{HBO} 2 \mathrm{e}$ fase Taal en cultuur

BOL MKF Restaurateur

BBL BB Verkoopmedewerker

BBL KF Bloemschikken

BBL Specialist Restauratieschilder

HBO Onderwijs 
Tabel B2.2 (vervolg)

Belangrijkste opleidingen van schoolverlaters die een vervolgopleiding zijn gaan volgen

BOL MKF Reclame, presentatie en communicatie

HBO Communicatie

HBO Beeldende kunst en vormgeving - vrij

HBO Kunst en techniek

BOL MKF Werktuigbouwkunde

HBO Werktuigbouwkunde

HBO Autotechniek

HBO Technische bedrijfskunde

BOL MKF Motorvoertuigen

HBO Autotechniek

BBL Specialist Eerste auto-elektrotechnicus

BOL MKF Ondernemer groothandel

HBO Kort Bedrijfsmanagement

HBO Kort Marketing management

HBO Technische bedrijfskunde

HBO Sport en bewegen

BOL MKF Energie- en informatietechniek

HBO Elektrotechniek

HBO Technische bedrijfskunde

HBO Hogere informatica

BOL MKF Informatietechniek

HBO Hogere informatica

HBO Elektrotechniek

HBO Bedrijfskundige informatica

HBO Informatica en informatiekunde

BOL MKF Laboratoriumtechniek

HBO Laboratoriumtechniek

HBO Biologie en medisch laboratoriumonderzoek

BOL MKF Transport en logistiek

HBO Logistiek en technische vervoerskunde

HBO Logistiek en economie

BOL MKF Bedrijfsadministratief

HBO Bedrijfseconomie

HBO Accountancy

HBO Management, economie en recht

HBO Commerciele economie

HBO Duaal Bedrijfseconomie

BOL MKF Commercieel

HBO Commerciele economie

HBO Management, economie en recht

HBO Facilitair management

HBO Communicatie

HBO International Business Studies (IBS)

HBO Personeel en arbeid

BOL MKF Economisch-juridisch

HBO Management, economie en recht

HBO Accountancy

HBO Sociaal-juridische dienstverlening

HBO Bestuurskunde/overheidsmanagement 
Tabel B2.2 (vervolg)

Belangrijkste opleidingen van schoolverlaters die een vervolgopleiding zijn gaan volgen

BOL MKF Economisch-juridisch (vervolg)

HBO Culturele en maatschappelijke vorming

WO Criminologie

BOL MKF Secretarieel

HBO Communicatie

HBO Commerciele economie

$\mathrm{HBO}$ Informatiedienstverlening en -management

HBO Personeel en arbeid

HBO Kunst/mediamanagement

BOL MKF Detailhandel/ambulante handel

HBO Small business en retail management

HBO Management, economie en recht

HBO Commerciele economie

HBO Kort Marketing management

HBO Communicatie

8

7

7

7

BOL MKF Groothandel/distributie

HBO Commerciele economie

HBO Facilitair management

HBO Communicatie

BOL MKF Horeca, instellingskeuken en contractcatering

HBO Hoger hotelonderwijs

HBO Bedrijfseconomie

HBO Kort Hotel (en hospitality) management

HBO Kort Marketing management

BOL MKF Toerisme, recreatie en reizen

HBO Hoger toeristisch en recreatief onderwijs

HBO Toerisme en recreatie (bedrijfsmanagement)

HBO Vrijetijdskunde

HBO International Business Studies (IBS)

BOL MKF Assistenten gezondheidszorg

HBO Opleiding tot verpleegkundige

HBO Opleiding mondhygienist

In-service Operatie-assistent chirurgie

HBO Operatie-assistent chirurgie

BOL MKF Sport en bewegen

HBO Fysiotherapie

HBO Sport en bewegen

HBO Sociaal pedagogische hulpverlening

HBO Kort Sport-management

HBO Leraar VO lichamelijke oefening (1e gr.)

HBO Leraar basisonderwijs

BOL MKF Verpleging en verzorging

$\mathrm{HBO}$ Opleiding tot verpleegkundige

BOL MKF Maatschappelijke dienstverlening

HBO Maatschappelijk werk en dienstverlening

HBO Culturele en maatschappelijke vorming

HBO Personeel en arbeid

BBL MKF Activiteitenbegeleider

HBO Hoger toeristisch en recreatief onderwijs

HBO Leraar VO geschiedenis (2e gr.)

HBO Sociaal-juridische dienstverlening

14

11

7 
Tabel B2.2 (vervolg)

Belangrijkste opleidingen van schoolverlaters die een vervolgopleiding zijn gaan volgen

BOL MKF Sociaal-pedagogisch werk algemeen

HBO Sociaal pedagogische hulpverlening

HBO Leraar basisonderwijs

HBO Maatschappelijk werk en dienstverlening

HBO Pedagogiek

BOL MKF Sociaal-juridisch werk

HBO Personeel en arbeid

BBL BB Bloemschikken

BBL ZB Bloemschikken

BBL Specialist Bloembinden

BOL ZB Bloemschikken

BBL BB Groene ruimte

BBL ZB Groene ruimte

BBL ZB Tuincentrum

BBL ZB Klein groen

BBL ZB Groot groen

BBL BB Bouw

BBL ZB Voortgezette timmerkracht

BBL ZB Voortgezette metselaar

BBL BB Houtbewerking en woninginrichting

BBL ZB Allround meubelmaker/interieurbouwer/scheepsinterieur $\quad 25$

BBL ZB Machinaal houtbewerken

BOL ZB Allround meubelmaker/interieurbouwer/scheepsinterieur $\quad 8$

BBL ZB Allround werkplaatstimmerman $\quad 8$

BBL ZB Allround machinaal houtbewerker timmer-/meubelindustrie $\quad 8$

BBL BB Motorvoertuigen

BBL ZB Eerste autotechnicus

BOL ZB Eerste monteur elektrotechnische panelen

BBL BB Motorfietstechnicus

BBL ZB Wegvervoer

BBL Specialist Diagnosetechnicus personenautos

BBL BB Energietechniek

BBL ZB Eerste monteur sterkstroominstallaties

BOL ZB Eerste monteur elektrotechnisch wikkelen

BBL AB Techniek

BBL ZB Onderhoudsmonteur elektro en instrumentatie

$\mathrm{BBL}$ ZB Eerste monteur elektrische bedrijfsinstallaties

BBL ZB Eerste monteur elektro en instrumentatie

BBL ZB Eerste monteur communicatie-installaties

BBL BB Installatie-, service- en onderhoudstechniek

$\mathrm{BBL}$ ZB Installatiemonteur met specialisatie woningbouw

BBL ZB Servicemonteur installatietechniek

BBL BB Primaire dakdekker

BBL BB Onderhoudsmonteur elektro en instrumentatie

BBL ZB Distributiemonteur gas

BBL ZB Dakbedekkingsmonteur

BBL ZB Installatiemonteur met specialisatie utiliteit

BBL BB Horeca, instellingskeuken en contractcatering

BBL ZB Zelfstandig werkend kok 
Tabel B2.2 (vervolg)

Belangrijkste opleidingen van schoolverlaters die een vervolgopleiding zijn gaan volgen

BBL BB Verpleging en verzorging

$B B L Z B$ Verzorgende

$B B L$ ZB Verpleging en verzorging

BBL ZB Sociaal-pedagogisch werk

BOL ZB Verzorgende

$\mathrm{HBO} 2 \mathrm{e}$ fase Interieurarchitectuur

BBL ZB Groene ruimte

HBO Tuin- en landschapsinrichting

BOL MKF Landbouwtechniek

BBL ZB Klein groen

BBL ZB Groot groen

HBO Beheer \& behoud

BBL ZB Bouw

BBL MKF Assistent-uitvoerder B\&U

HBO Kort Bouwkunde

BBL BB Tegelzetter

BBL MKF Kaderfunctionaris timmerindustrie

HBO Bouwkunde

BBL ZB Installatie-, service- en onderhoudstechniek

BBL ZB Servicemonteur verwarmingstechniek

BBL ZB Aankomend projecttechnicus gebouwinstallaties

BBL ZB Servicemonteur installatietechniek

BBL ZB Installatie-, service- en onderhoudstechnie

BBL ZB Verpleging en verzorging

BBL MKF Verpleegkundige

BBL MKF Verpleging en verzorging

BOL MKF Verpleegkundige

BBL MKF Gezondheidszorg

BBL Specialist Praktijkopleider (verpleging en verzorgende)

Zie ook toelichting bladzijde 15 
Tabel B2.3

Oordeel van schoolverlaters over de aansluiting van de afgesloten opleiding met de vervolgopleiding

\begin{tabular}{lrrr}
\hline Opleidingsrichting & goed & voldoende & matig \\
$\%$ & slech & $\%$
\end{tabular}

\section{VBO}

IVBO Landbouw en natuurlijke omgeving

IVBO Verzorging

Landbouw en natuurlijke omgeving

Bouwtechniek

Mechanische techniek

Elektrotechniek

Motorvoertuigentechniek

Consumptieve techniek

Nautische opleidingen

Administratie

Verkoop

Verzorging

Uiterlijke verzorging

$\begin{array}{rrrr}50 & 33 & 12 & 5 \\ 58 & 32 & 11 & 0 \\ 47 & 36 & 12 & 6 \\ 65 & 29 & 7 & 0 \\ 45 & 39 & 6 & 10 \\ 45 & 42 & 8 & 5 \\ 71 & 18 & 7 & 4 \\ 69 & 24 & 3 & 3 \\ 54 & 31 & 12 & 4 \\ 53 & 30 & 8 & 8 \\ 53 & 42 & 5 & 0 \\ 67 & 28 & 4 & 1 \\ 62 & 31 & 8 & 0 \\ & & & \\ & & & \\ 35 & 30 & 12 & 24 \\ 40 & 60 & 0 & 0 \\ 62 & 31 & 5 & 2 \\ 56 & 34 & 5 & 5\end{array}$

BOL niveau $1 / 2$

AB Beveiliging

BB Detailhandel/ambulante handel

BB Horeca, instellingskeuken en contractcatering

BB Verpleging en verzorging

BOL niveau $3 / 4$

ZB Plantenteelt

ZB Veehouderij

ZB Bloemschikken

ZB Dierverzorging en veterinaire ondersteuning

ZB Groene ruimte

ZB Groothandel/distributie

ZB Verpleging en verzorging

KF Plantenteelt

KF Veehouderij

KF Levensmiddelentechnologie

KF Dierverzorging en veterinaire ondersteuning

KF Groene ruimte

KF Milieutoezicht

MKF Bouw

MKF Houtbewerking en woninginrichting

MKF Grond-, water- en wegenbouw

MKF Beschermings- en afwerkingstechnieken

MKF Reclame, presentatie en communicatie

MKF Werktuigbouwkunde

MKF Motorvoertuigen

MKF Energie- en informatietechniek

MKF Informatietechniek

MKF Laboratoriumtechniek

MKF Transport en logistiek

MKF Bedrijfsadministratief

MKF Commercieel

MKF Economisch-juridisch

MKF Secretarieel

MKF Detailhandel/ambulante handel

MKF Groothandel/distributie

MKF Horeca, instellingskeuken en contractcatering

MKF Toerisme, recreatie en reizen

MKF Assistenten gezondheidszorg

MKF Sport en bewegen

MKF Verpleging en verzorging

$\begin{array}{rrrr}27 & 45 & 23 & 6 \\ 46 & 32 & 7 & 15 \\ 24 & 43 & 15 & 17 \\ 42 & 27 & 15 & 15 \\ 53 & 22 & 14 & 11 \\ 40 & 47 & 13 & 0 \\ 44 & 37 & 15 & 4 \\ 31 & 49 & 14 & 5 \\ 48 & 28 & 20 & 3 \\ 52 & 33 & 9 & 5 \\ 56 & 38 & 4 & 1 \\ 34 & 38 & 24 & 4 \\ 25 & 53 & 22 & 0 \\ 34 & 49 & 12 & 5 \\ 20 & 48 & 18 & 14 \\ 50 & 32 & 9 & 9 \\ 36 & 28 & 14 & 22 \\ 46 & 29 & 23 & 2 \\ 32 & 47 & 11 & 11 \\ 44 & 31 & 19 & 6 \\ 17 & 40 & 34 & 9 \\ 50 & 41 & 7 & 2 \\ 43 & 38 & 15 & 3 \\ 21 & 41 & 17 & 21 \\ 42 & 37 & 10 & 12 \\ 26 & 42 & 19 & 12 \\ 33 & 10 & 40 & 16 \\ 27 & 55 & 6 & 11 \\ 27 & 36 & 30 & 7 \\ 27 & 48 & 25 & 0 \\ 51 & 25 & 15 & 9 \\ 53 & 40 & 2 & 5 \\ 35 & 31 & 18 & 16 \\ 47 & 41 & 10 & 2 \\ 50 & 21 & 24 & 5\end{array}$


Tabel B2.3 (vervolg)

Oordeel van schoolverlaters over de aansluiting van de afgesloten opleiding met de vervolgopleiding

\begin{tabular}{lrrr}
\hline Opleidingsrichting & $\begin{array}{r}\text { goed } \\
\%\end{array}$ & $\begin{array}{r}\text { voldoende } \\
\%\end{array}$ & $\begin{array}{r}\text { matig } \\
\%\end{array}$ \\
& & $\begin{array}{r}\text { slecht } \\
\%\end{array}$ \\
\hline
\end{tabular}

BOL niveau 3/4 (vervolg)

MKF Sociaal-pedagogisch werk algemeen

MKF Sociaal-juridisch werk

42

43

38

41

11

Zie ook toelichting bladzijde 16 
Tabel B2.4

Doorstroom van schoolverlaters naar kenniscentrum beroepsonderwijs bedrijfsleven

IVBO Landbouw en natuurlijke omgeving AEQUOR

OVDB

KC Handel

IVBO Verzorging

OVDB

ECABO

AEQUOR

HTV

VBO Landbouw en natuurlijke omgeving

AEQUOR

OVDB

ECABO

VBO Bouwtechniek

Bouwradius

SH\&M

SVS

SOM

VBO Mechanische techniek

SOM

VTenL

INNOVAM

Intechnium

SBW

VBO Elektrotechniek

VEV/LOB-E

VTenL

VBO Motorvoertuigentechniek

INNOVAM

VOC-Car

VTenL

VBO Consumptieve techniek

HTV

VBO Nautische opleidingen

VTenL

VBO Administratie

ECABO

OVDB

KC Handel

HTV

VBO Verkoop

KC Handel

OVDB

ECABO

VBO Verzorging

OVDB 
Tabel B2.4 (vervolg)

Doorstroom van schoolverlaters naar kenniscentrum beroepsonderwijs bedrijfsleven

VBO Uiterlijke verzorging

KOC

OVDB

ECABO

BOL AB Beveiliging

OVDB

ECABO

KC Handel

BOL BB Detailhandel/ambulante handel

KC Handel

BOL BB Horeca, instellingskeuken en contractcatering HTV

BOL BB Verpleging en verzorging

OVDB

BOL ZB Plantenteelt

SOM

SBW

AEQUOR

INNOVAM

KC Handel

BOL ZB Veehouderij

AEQUOR

Intechnium

BOL ZB Bloemschikken

AEQUOR

OVDB

BOL ZB Dierverzorging en veterinaire ondersteuning

AEQUOR

VaPro - OVP

$\mathrm{SH} \& \mathrm{M}$

HTV

OVDB

BOL ZB Groene ruimte

AEQUOR

SVS

HTV

BOL ZB Groothandel/distributie

ECABO

$B O L$ ZB Verpleging en verzorging

OVDB

BOL KF Plantenteelt

AEQUOR

OVDB

BOL KF Veehouderij

AEQUOR 
Tabel B2.4 (vervolg)

Doorstroom van schoolverlaters naar kenniscentrum beroepsonderwijs bedrijfsleven

BOL KF Veehouderij (vervolg)

OVDB

SOM

VTenL

BOL KF Levensmiddelentechnologie

AEQUOR

ECABO

VaPro - OVP

BOL KF Dierverzorging en veterinaire ondersteuning AEQUOR

KC Handel

BOL KF Groene ruimte

AEQUOR

VEV/LOB-E

INNOVAM

SBW

ECABO

OVDB

BOL KF Milieutoezicht

AEQUOR

BOL MKF Bouw

Bouwradius

SH\&M

BOL MKF Houtbewerking en woninginrichting

Intechnium

GOC

SVS

ECABO

BOL MKF Beschermings- en afwerkingstechnieken

SVS

VOC-Car

AEQUOR

KC Handel

HTV

SH\&M

BOL MKF Reclame, presentatie en communicatie GOC

BOL MKF Werktuigbouwkunde

SOM

BOL MKF Motorvoertuigen

INNOVAM

BOL MKF Energie- en informatietechniek VEV/LOB-E 
Tabel B2.4 (vervolg)

Doorstroom van schoolverlaters naar kenniscentrum beroepsonderwijs bedrijfsleven

BOL MKF Informatietechniek

VEV/LOB-E

BOL MKF Laboratoriumtechniek

OVDB

VaPro - OVP

BOL MKF Transport en logistiek

VEV/LOB-E

VTenL

ECABO

KC Handel

BOL MKF Commercieel

OVDB

KC Handel

BOL MKF Detailhandel/ambulante handel

ECABO

VEV/LOB-E

OVDB

VTenL

SVGB

LIFT Groep

KC Handel

BOL MKF Groothandel/distributie

INNOVAM

GOC

ECABO

KC Handel

KOC

BOL MKF Horeca, instellingskeuken en contractcatering

ECABO

BOL MKF Toerisme, recreatie en reizen OVDB

BOL MKF Assistenten gezondheidszorg

In-service Operatie-assistent

OVDB

KOC

In-service Laborant

BOL MKF Sport en bewegen

BOL MKF Verpleging en verzorging

In-service Operatie-assistent

BOL MKF Maatschappelijke dienstverlening OVDB

BOL MKF Sociaal-pedagogisch werk algemeen OVDB 
Tabel B2.4 (vervolg)

Doorstroom van schoolverlaters naar kenniscentrum beroepsonderwijs bedrijfsleven

BOL MKF Sociaal-juridisch werk

OVDB

BBL BB Bloemschikken

AEQUOR

BBL BB Groene ruimte

AEQUOR

BBL BB Bouw

Bouwradius

BBL BB Houtbewerking en woninginrichting

SH\&M

BBL BB Motorvoertuigen

INNOVAM

VEV/LOB-E

VTenL

BBL BB Energietechniek

VEV/LOB-E

SOM

BBL BB Installatie-, service- en onderhoudstechniek

Intechnium

SOM

Bouwradius

HTV

OVDB

BBL ZB Groene ruimte

AEQUOR

BBL ZB Bouw

Bouwradius

SH\&M

BBL ZB Installatie-, service- en onderhoudstechniek

Intechnium

$B B L$ ZB Verpleging en verzorging

Zie ook toelichting bladzijde 19 
Tabel B3.1

Werkloosheid en gemiddelde intredewerkloosheid van schoolverlaters die zich aanbieden op de arbeidsmarkt

\begin{tabular}{|c|c|c|c|c|c|c|c|c|}
\hline \multirow[t]{2}{*}{ Opleidingsrichting } & \multirow{2}{*}{$\begin{array}{r}\text { aanbieden } \\
\text { op arbeids- } \\
\text { markt } \\
\%\end{array}$} & \multirow{2}{*}{$\begin{array}{r}\text { werk- } \\
\text { loosheid } \\
\%\end{array}$} & \multicolumn{5}{|c|}{ werkloos tijdens intredeperiode in klassen } & \multirow{2}{*}{$\begin{array}{r}\text { intrede- } \\
\text { werk- } \\
\text { loosheid } \\
\text { maanden }\end{array}$} \\
\hline & & & $\begin{array}{r}0 \text { mnd. } \\
\%\end{array}$ & $\begin{array}{r}1-3 \text { mnd. } \\
\%\end{array}$ & $\begin{array}{r}\text { 4-6 mnd. } \\
\%\end{array}$ & $\begin{array}{r}7-12 \text { mnd. } \\
\%\end{array}$ & $\begin{array}{r}\geq 13 \text { mnd. } \\
\%\end{array}$ & \\
\hline \multicolumn{9}{|l|}{ VBO } \\
\hline IVBO Landbouw en natuurlijke omgeving & 58 & 7 & 90 & 7 & 2 & 1 & 0 & 0,4 \\
\hline IVBO Bouwtechniek & 86 & 8 & 83 & 8 & 8 & 0 & 0 & 0,6 \\
\hline IVBO Verzorging & 50 & 10 & 70 & 10 & 10 & 10 & 0 & 1,7 \\
\hline Landbouw en natuurlijke omgeving & 41 & 2 & 92 & 5 & 2 & 0 & 1 & 0,3 \\
\hline Bouwtechniek & 76 & 3 & 99 & 0 & 1 & 0 & 0 & 0,0 \\
\hline Mechanische techniek & 51 & 0 & 95 & 5 & 0 & 0 & 0 & 0,1 \\
\hline Elektrotechniek & 44 & 2 & 97 & 0 & 0 & 3 & 0 & 0,2 \\
\hline Motorvoertuigentechniek & 69 & 0 & 95 & 0 & 0 & 5 & 0 & 0,4 \\
\hline Consumptieve techniek & 69 & 4 & 96 & 4 & 0 & 0 & 0 & 0,1 \\
\hline Nautische opleidingen & 52 & 0 & 92 & 8 & 0 & 0 & 0 & 0,2 \\
\hline Administratie & 23 & 7 & 100 & 0 & 0 & 0 & 0 & 0,0 \\
\hline Verkoop & 51 & 4 & 91 & 4 & 0 & 4 & 0 & 0,4 \\
\hline Verzorging & 29 & 2 & 88 & 5 & 4 & 2 & 0 & 0,5 \\
\hline Uiterlijke verzorging & 55 & 4 & 88 & 4 & 8 & 0 & 0 & 0,5 \\
\hline \multicolumn{9}{|l|}{ BOL niveau $1 / 2$} \\
\hline AB Motorvoertuigen & 83 & 10 & 100 & 0 & 0 & 0 & 0 & 0,0 \\
\hline AB Beveiliging & 71 & 5 & 95 & 3 & 2 & 0 & 0 & 0,2 \\
\hline$A B$ Secretarieel & 50 & 57 & 100 & 0 & 0 & 0 & 0 & 0,0 \\
\hline$A B$ Verpleging en verzorging & 23 & 24 & 53 & 24 & 24 & 0 & 0 & 1,2 \\
\hline BB Plantenteelt & 100 & 3 & 82 & 11 & 4 & 0 & 4 & 1,0 \\
\hline BB Bloemschikken & 87 & 2 & 98 & 0 & 0 & 0 & 2 & 0,3 \\
\hline BB Dierverzorging en veterinaire ondersteuning & 52 & 30 & 26 & 65 & 0 & 9 & 0 & 1,4 \\
\hline BB Groene ruimte & 100 & 5 & 95 & 0 & 5 & 0 & 0 & 0,3 \\
\hline BB Houtbewerking en woninginrichting & 67 & 3 & 97 & 3 & 0 & 0 & 0 & 0,1 \\
\hline BB Reclame, presentatie en communicatie & 37 & 21 & 69 & 21 & 10 & 0 & 0 & 0,9 \\
\hline
\end{tabular}


Tabel B3.1 (vervolg)

Werkloosheid en gemiddelde intredewerkloosheid van schoolverlaters die zich aanbieden op de arbeidsmarkt

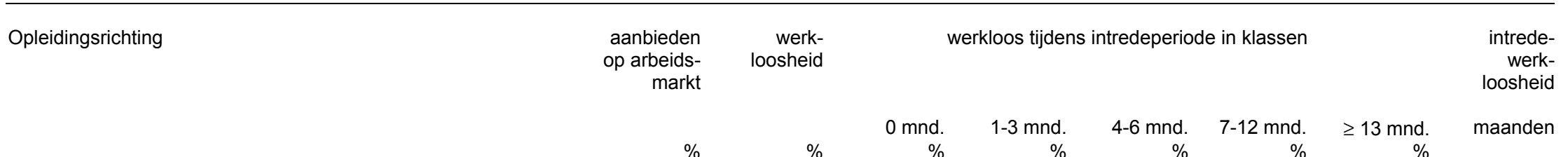

\section{BOL niveau 1/2 (vervolg)}

BB Motorvoertuigen

BB Graf. techn, communicatie, audiovisueel en multimedia

BB Bedrijfsadministratie

BB Secretariee

BB Detailhandel/ambulante handel

BB Horeca, instellingskeuken en contractcatering

BB Facilitaire dienstverlening

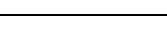

BB Verpleging en $v$

\section{BOL niveau $3 / 4$}

ZB Plantenteelt

ZB Veehouderij

ZB Levensmiddelentechnologie

ZB Bloemschikken

ZB Dierverzorging en veterinaire ondersteuning

ZB Paardenhouderij en paardensport

ZB Groene ruimte

ZB Werktuigbouwkunde

ZB Graf. techn, communicatie, audiovisueel en multimedia

$\% \quad 7-12$ mnd.

$\%$

maanden

ZB Scheepvaart

ZB Bedrijfsadministratie

ZB Detailhandel/ambulante handel

ZB Detailhandel/ambulan

ZB Toerisme, recreatie en reizen

$Z B$ Verpleging en verzorging

ZB Uiterlijke verzorging

87
77
54
55
69
76
69
54

$\begin{array}{rr}0 & 100 \\ 12 & \\ 0 & \\ 0 & \\ 8 & \\ 7 & \\ 0 & 100 \\ 4 & \end{array}$

$\begin{array}{rrrlll}100 & 0 & 0 & 0 & 0 & 0,0 \\ 71 & 29 & 0 & 0 & 0 & 0,4 \\ 92 & 0 & 8 & 0 & 0 & 0,5 \\ 50 & 33 & 8 & 8 & 0 & 1,9 \\ 91 & 4 & 4 & 0 & 0 & 0,3 \\ 84 & 14 & 1 & 0 & 0 & 0,3 \\ 100 & 0 & 0 & 0 & 0 & 0,0 \\ 77 & 17 & 7 & 0 & 0 & 0,6\end{array}$

KF Plantenteelt 
Tabel B3.1 (vervolg)

Werkloosheid en gemiddelde intredewerkloosheid van schoolverlaters die zich aanbieden op de arbeidsmarkt

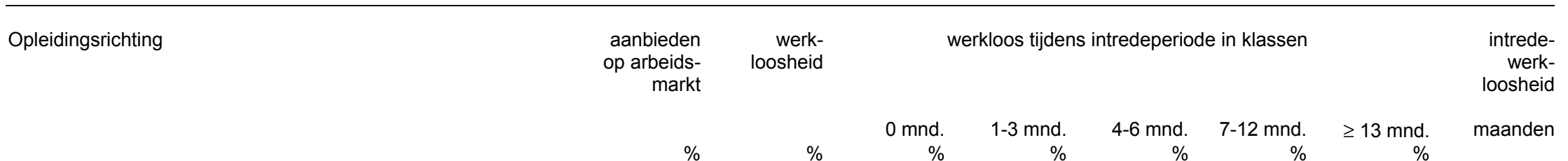

BOL niveau 3/4 (vervolg)

KF Veehouderij

KF Levensmiddelentechnologie

KF Bloemschikken

KF Dierverzorging en veterinaire ondersteuning

KF Paardenhouderij en paardensport

KF Groene ruimte

KF Milieutoezich

MKF Houtbewerking en woninginrichting

MKF Grond-, water- en wegenbouw

MKF Beschermings- en afwerkingstechnieken

MKF Reclame, presentatie en communicatie

MKF Operationele techniek

MKF Werktuigbouwkunde

MKF Motorvoertuigen

MKF Energie- en informatietechniek

MKF Energietechniek

MKF Informatietechniek

MKF Graf. techn, communicatie, audiovisueel en multimedia

MKF Laboratoriumtechniek

MKF Procestechniek

MKF Scheepvaart

MKF Transport en logistiek

MKF Automatisering

MKF Bedrijfsadministratief

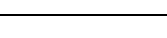

aanden

MKF Economisch-juridisch

$\begin{array}{rrr}57 & 4 & 95 \\ 58 & 3 & 92 \\ 77 & 4 & 92 \\ 67 & 0 & 82 \\ 68 & 0 & 93 \\ 53 & 4 & 84 \\ 31 & 0 & 80 \\ 43 & 3 & 90 \\ 71 & 5 & 87 \\ 57 & 7 & 84 \\ 80 & 6 & 83 \\ 55 & 6 & 74 \\ 81 & 0 & 84 \\ 40 & 8 & 79 \\ 60 & 0 & 94 \\ 34 & 6 & 88 \\ 53 & 0 & 100 \\ 40 & 6 & 85 \\ 76 & 11 & 88 \\ 49 & 5 & 87 \\ 42 & 0 & 85 \\ 58 & 0 & 93 \\ 70 & 2 & 100 \\ 46 & 9 & 67 \\ 47 & 5 & 95 \\ 47 & 6 & 80 \\ 37 & 10 & 100\end{array}$


Tabel B3.1 (vervolg)

Werkloosheid en gemiddelde intredewerkloosheid van schoolverlaters die zich aanbieden op de arbeidsmarkt

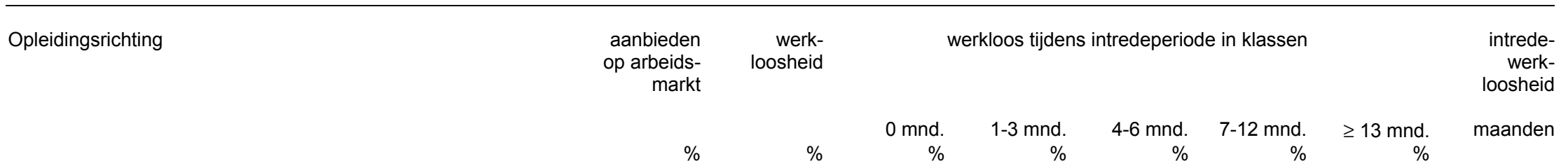

\section{BOL niveau 3/4 (vervolg)}

MKF Secretarieel

MKF Detailhandel/ambulante hande

MKF Groothandel/distributie

MKF Horeca, instellingskeuken en contractcatering

MKF Toerisme, recreatie en reizen

MKF Assistenten gezondheidszorg

MKF Facilitaire dienstverlening

MKF Sport en bewegen

MKF Verpleging en verzorging

MKF Maatschappelijke dienstverlening

MKF Sociaal-pedagogisch werk algemeen

MKF Sociaal-juridisch werk

0 mnd.

aanden

\section{$B B L$ niveau $\mathbf{1 / 2}$}

$A B$ Groene ruimte

$A B$ Beveiliging

AB Detailhandel/ambulante handel

$A B$ Verpleging en verzorging

BB Plantenteelt

BB Bloemschikken

BB Groene ruimte

BB Bouw

BB Houtbewerking en woninginrichting

BB Grond-, water en wegenbouw

BB Beschermings- en afwerkingstechnieken

BB Contructio-,

BB Montage/onderhoud/operationele techniek

$\begin{array}{llr}64 & 0 & 88 \\ 54 & 4 & 94 \\ 23 & 0 & 82 \\ 67 & 1 & 88 \\ 67 & 8 & 83 \\ 75 & 1 & 97 \\ 67 & 0 & 89 \\ 52 & 0 & 92 \\ 80 & 0 & 10 \\ 32 & 0 & 82 \\ 53 & 6 & 88 \\ 57 & 4 & 88\end{array}$

$\begin{array}{rlll}4 & 0 & 0 & 0,4 \\ 0 & 0 & 0 & 0,1 \\ 0 & 0 & 0 & 0,2 \\ 1 & 0 & 0 & 0,2 \\ 3 & 2 & 0 & 0,6 \\ 0 & 0 & 0 & 0,0 \\ 11 & 0 & 0 & 0,7 \\ 3 & 0 & 0 & 0,3 \\ 0 & 0 & 0 & 0,0 \\ 0 & 0 & 0 & 0,2 \\ 4 & 1 & 0 & 0,4 \\ 8 & 0 & 0 & 0,5\end{array}$

$\begin{array}{rr}94 & 0 \\ 96 & 4 \\ 96 & 15 \\ 100 & 5 \\ 95 & 5 \\ 91 & 3 \\ 98 & 0 \\ 99 & 3 \\ 87 & 5 \\ 93 & 8 \\ 100 & 0 \\ 94 & 2 \\ 100 & 0\end{array}$

0
8
4
0
0
0
1
0
3
0
0
0
0

0
8
0
11
0
0
1
0
0
0
0
0
0

$\begin{array}{ll}0 & 0,1 \\ 0 & 1,0 \\ 0 & 0,2 \\ 0 & 0,7 \\ 0 & 0,0 \\ 2 & 0,3 \\ 0 & 0,3 \\ 1 & 0,3 \\ 0 & 0,3 \\ 0 & 0,1 \\ 7 & 1,5 \\ 0 & 0,0 \\ 0 & 0,2\end{array}$


Tabel B3.1 (vervolg)

Werkloosheid en gemiddelde intredewerkloosheid van schoolverlaters die zich aanbieden op de arbeidsmarkt

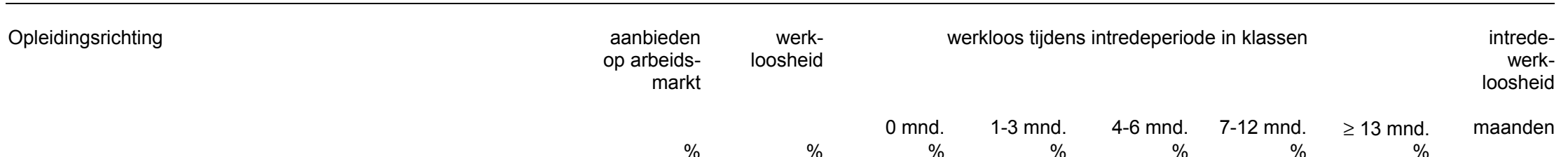

\section{$B B L$ niveau $1 / 2$ (vervolg)}

BB Motorvoertuigen

maanden

BB Energie- en informatietechniek

BB Energietechniek

BB Installatie-, service- en onderhoudstechniek

BB Procestechniek

BB Wegvervoer

BB Detailhandel/ambulante handel

BB Opslag/magazijn

BB Horeca, instellingskeuken en contractcatering

BB Facilitaire dienstverlening

$B B$ Verpleging en verzorging

$\begin{array}{rrr} & & \\ 93 & 0 & 100 \\ 93 & 0 & 85 \\ 97 & 6 & 91 \\ 95 & 1 & 99 \\ 100 & 4 & 100 \\ 99 & 0 & 94 \\ 99 & 7 & 95 \\ 100 & 8 & 92 \\ 94 & 0 & 94 \\ 94 & 6 & 94 \\ 97 & 0 & 99 \\ 100 & 0 & 87 \\ & & \end{array}$

\section{BBL niveau 3/4}

ZB Plantenteelt

ZB Bloemschikken

ZB Groene ruimte

ZB Bouw

ZB Grond-, water- en wegenbouw

ZB Constructie-, plaatwerken/pijpenbewerken

ZB Motorvoertuigen

ZB Energie- en informatietechniek

ZB Energietechniek

ZB Beheer, ontwerp en management (instal. techn)

ZB Installatie-, service- en onderhoudstechniek

ZB Procestechniek

$\begin{array}{rrr}86 & 0 & 100 \\ 98 & 1 & 100 \\ 91 & 0 & 94 \\ 96 & 0 & 98 \\ 97 & 0 & 94 \\ 89 & 4 & 100 \\ 100 & 0 & 89 \\ 100 & 0 & 100 \\ 89 & 0 & 100 \\ 100 & 0 & 100 \\ 100 & 0 & 99 \\ 95 & 5 & 95 \\ 84 & 12 & 81\end{array}$

$\begin{array}{rl}0 & 0 \\ 8 & 8 \\ 3 & \\ 1 & 0 \\ 0 & 0 \\ 5 & \\ 5 & \\ 0 & 0 \\ 6 & 4 \\ 6 & 0 \\ 0 & 0 \\ 13 & \end{array}$

0
0
2
0
0
0
6
0
0
0
0
0
6


Tabel B3.1 (vervolg)

Werkloosheid en gemiddelde intredewerkloosheid van schoolverlaters die zich aanbieden op de arbeidsmarkt

\begin{tabular}{|c|c|c|c|c|c|c|c|c|}
\hline \multirow[t]{2}{*}{ Opleidingsrichting } & \multirow{2}{*}{$\begin{array}{r}\text { aanbieden } \\
\text { op arbeids- } \\
\text { markt } \\
\%\end{array}$} & \multirow{2}{*}{$\begin{array}{r}\text { werk- } \\
\text { loosheid } \\
\%\end{array}$} & \multicolumn{5}{|c|}{ werkloos tijdens intredeperiode in klassen } & \multirow{2}{*}{$\begin{array}{r}\text { intrede- } \\
\text { werk- } \\
\text { loosheid } \\
\text { maanden }\end{array}$} \\
\hline & & & $\begin{array}{r}0 \text { mnd. } \\
\%\end{array}$ & $\begin{array}{r}1-3 \text { mnd. } \\
\%\end{array}$ & $\begin{array}{r}4-6 \text { mnd. } \\
\%\end{array}$ & $\begin{array}{r}\text { 7-12 mnd. } \\
\%\end{array}$ & $\begin{array}{r}\geq 13 \text { mnd. } \\
\%\end{array}$ & \\
\hline \multicolumn{9}{|l|}{ BBL niveau 3/4 (vervolg) } \\
\hline ZB Detailhandel/ambulante handel & 100 & 6 & 87 & 8 & 6 & 0 & 0 & 0,4 \\
\hline ZB Opslag/magazijn & 93 & 7 & 85 & 15 & 0 & 0 & 0 & 0,2 \\
\hline ZB Horeca, instellingskeuken en contractcatering & 95 & 0 & 92 & 2 & 5 & 0 & 0 & 0,3 \\
\hline ZB Verpleging en verzorging & 97 & 0 & 99 & 1 & 0 & 0 & 0 & 0,0 \\
\hline ZB Uiterlijke verzorging & 96 & 0 & 98 & 2 & 0 & 0 & 0 & 0,0 \\
\hline MKF Bouw & 100 & 6 & 100 & 0 & 0 & 0 & 0 & 0,0 \\
\hline MKF Detailhandel/ambulante handel & 88 & 0 & 100 & 0 & 0 & 0 & 0 & 0,0 \\
\hline MKF Horeca, instellingskeuken en contractcatering & 93 & 7 & 85 & 7 & 7 & 0 & 0 & 0,4 \\
\hline MKF Verpleging en verzorging & 94 & 0 & 98 & 0 & 0 & 2 & 0 & 0,1 \\
\hline MKF Sociaal-pedagogisch werk & 93 & 1 & 92 & 1 & 4 & 1 & 2 & 0,6 \\
\hline Specialist Energietechniek & 96 & 1 & 100 & 0 & 0 & 0 & 0 & 0,0 \\
\hline Specialist Verpleging en verzorging & 100 & 0 & 100 & 0 & 0 & 0 & 0 & 0,0 \\
\hline
\end{tabular}

Zie ook toelichting bladzijde 22 
Tabel B3.2

Aard van het dienstverband van werkende schoolverlaters

\begin{tabular}{|c|c|c|c|c|c|c|}
\hline Opleidingsrichting & $\begin{array}{r}\text { leer/werk- } \\
\text { overeen- } \\
\text { komst } \\
\%\end{array}$ & $\begin{array}{r}\text { uitzend-, } \\
\text { oproepkracht } \\
\%\end{array}$ & $\begin{array}{r}\text { loondienst } \\
\text { werkgever } \\
\%\end{array}$ & $\begin{array}{r}\text { gesubsidieerde } \\
\text { arbeid (WIW) } \\
\%\end{array}$ & $\begin{array}{r}\text { bedrijf } \\
\text { ouders/ } \\
\text { partner } \\
\%\end{array}$ & $\begin{array}{r}\text { eigen bedrijf } / \\
\text { free-lance } \\
\%\end{array}$ \\
\hline
\end{tabular}

IVBO Landbouw en natuurlijke omgeving

Landbouw en natuurlijke omgeving

Bouwtechniek

Mechanische techniek

Elektrotechniek

Motorvoertuigentechniek

Consumptieve techniek

Administratie

Verkoop

Verzorging

Uiterlijke verzorging

49

53

9

59
75

63

BOL niveau $1 / 2$

AB Beveiliging

BB Plantenteelt

BB Bloemschikken

BB Groene ruimte

BB Houtbewerking en woninginrichting

BB Detailhandel/ambulante handel

BB Horeca, instellingskeuken en contractcatering

$B B$ Verpleging en verzorging

\section{BOL niveau $3 / 4$}

ZB Plantenteelt

ZB Veehouderij

ZB Bloemschikken

ZB Dierverzorging en veterinaire ondersteuning

ZB Paardenhouderij en paardensport

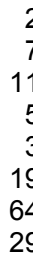

11

5
3

17

51

46
32$$
\begin{array}{r}
7 \\
11
\end{array}
$$

7
11
9

$\begin{array}{rr}1 & 2 \\ 1 & 0 \\ 0 & 0 \\ 0 & 11 \\ 0 & 0 \\ 0 & 5 \\ 0 & 0 \\ 0 & 0 \\ 0 & 0 \\ 0 & 0 \\ 0 & 0\end{array}$

14


Tabel B3.2 (vervolg)

Aard van het dienstverband van werkende schoolverlaters

\begin{tabular}{|c|c|c|c|c|c|c|}
\hline Opleidingsrichting & $\begin{array}{r}\text { leer/werk- } \\
\text { overeen- } \\
\text { komst } \\
\%\end{array}$ & $\begin{array}{r}\text { uitzend-, } \\
\text { oproepkracht } \\
\%\end{array}$ & $\begin{array}{r}\text { loondienst } \\
\text { werkgever } \\
\%\end{array}$ & $\begin{array}{r}\text { gesubsidieerde } \\
\text { arbeid (WIW) } \\
\%\end{array}$ & $\begin{array}{r}\text { bedrijf } \\
\text { ouders/ } \\
\text { partner } \\
\%\end{array}$ & $\begin{array}{r}\text { eigen bedrijf/ } \\
\text { free-lance } \\
\%\end{array}$ \\
\hline
\end{tabular}

BOL niveau 3/4 (vervolg)

ZB Groene ruimte

ZB Graf, techn, communicatie, audiovisueel en multimedia

ZB Scheepvaart

ZB Bedriffsadministratie

ZB Toerisme, recreatie en reizen

ZB Verpleging en verzorging

ZB Uiterlijke verzorging

KF Plantenteelt

KF Veehouderij

KF Levensmiddelentechnologie

KF Bloemschikken

KF Dierverzorging en veterinaire ondersteuning

KF Paardenhouderij en paardensport

KF Groene ruimte

MKF Bouw

MKF Houtbewerking en woninginrichting

MKF Grond-, water- en wegenbouw

MKF Beschermings- en afwerkingstechnieken

MKF Reclame, presentatie en communicatie

MKF Werktuigbouwkunde

MKF Motorvoertuigen

MKF Energie- en informatietechniek

MKF Informatietechniek

MKF Graf. techn, communicatie, audiovisueel en multimedia

MKF Laboratoriumtechniek

MKF Scheepvaart

MKF Transport en logistiek

MKF Bedrijfsadministratief

MKF Commercieel

$\begin{array}{rrr}0 & 2 & 0 \\ 0 & 0 & 0 \\ 0 & 0 & 12 \\ 0 & 0 & 0 \\ 0 & 0 & 0 \\ 0 & 0 & 1 \\ 0 & 0 & 4 \\ 0 & 14 & 5 \\ 0 & 10 & 4 \\ 0 & 0 & 5 \\ 0 & 0 & 0 \\ 0 & 2 & 0 \\ 0 & 7 & 0 \\ 0 & 0 & 1 \\ 0 & 0 & 3 \\ 0 & 0 & 10 \\ 0 & 0 & 0 \\ 0 & 0 & 0 \\ 0 & 0 & 1 \\ 0 & 0 & 0 \\ 0 & 0 & 0 \\ 0 & 0 & 6 \\ 0 & 0 & 0 \\ 0 & 0 & 5 \\ 0 & 0 & 0 \\ 0 & 0 & 0 \\ 0 & 0 & 0 \\ 0 & 0 & 0 \\ 0 & 0 & \end{array}$


Tabel B3.2 (vervolg)

Aard van het dienstverband van werkende schoolverlaters

\begin{tabular}{|c|c|c|c|c|c|c|}
\hline Opleidingsrichting & $\begin{array}{r}\text { leer/werk- } \\
\text { overeen- } \\
\text { komst } \\
\%\end{array}$ & $\begin{array}{r}\text { uitzend-, } \\
\text { oproepkracht } \\
\%\end{array}$ & $\begin{array}{r}\text { loondienst } \\
\text { werkgever } \\
\%\end{array}$ & $\begin{array}{r}\text { gesubsidieerde } \\
\text { arbeid (WIW) } \\
\%\end{array}$ & $\begin{array}{r}\text { bedrijf } \\
\text { ouders/ } \\
\text { partner } \\
\%\end{array}$ & $\begin{array}{r}\text { eigen bedrijf/ } \\
\text { free-lance } \\
\%\end{array}$ \\
\hline
\end{tabular}

BOL niveau 3/4 (vervolg)

MKF Secretarie

MKF Detailhandel/ambulante handel

MKF Horeca, instellingskeuken en contractcatering

MKF Toerisme, recreatie en reizen

MKF Assistenten gezondheidszorg

MKF Sport en bewegen

MKF Verpleging en verzorging

MKF Sociaal-pedagogisch werk algemeen

MKF Sociaal-juridisch werk

$B B L$ niveau $1 / 2$

$A B$ Groene ruimte

AB Beveiliging

AB Detailhandel/ambulante handel

$A B$ Verpleging en verzorging

BB Plantenteelt

BB Bloemschikken

BB Groene ruimte

BB Bouw

BB Houtbewerking en woninginrichting

BB Grond-, water en wegenbouw

BB Constructie-, plaatwerken/pijpenbewerken

BB Montage/onderhoud/operationele techniek

BB Motorvoertuigen

BB Energietechniek

BB Installatie-, service- en onderhoudstechniek

BB Procestechniek

BB Wegvervoer

BB Detailhandel/ambulante handel

0
2
3
2
4
0
7
3
4

$\begin{array}{ll}6 & \\ 8 & \\ 3 & \\ 2 & \\ 1 & \\ 0 & \\ 0 & \\ 6 & \\ 4 & \end{array}$

94
90
93
95
94
100
91
91
91

0

$\begin{array}{rr}74 & 16 \\ 100 & 0 \\ 74 & 0 \\ 94 & 0 \\ 83 & 0 \\ 56 & 0 \\ 74 & 5 \\ 64 & 0 \\ 80 & 0 \\ 50 & 0 \\ 74 & 0 \\ 80 & 0 \\ 70 & 0 \\ 77 & 0 \\ 60 & 0 \\ 100 & 0 \\ 95 & 0 \\ 93 & 0\end{array}$


Tabel B3.2 (vervolg)

Aard van het dienstverband van werkende schoolverlaters

\begin{tabular}{|c|c|c|c|c|c|c|}
\hline Opleidingsrichting & $\begin{array}{r}\text { leer/werk- } \\
\text { overeen- } \\
\text { komst } \\
\%\end{array}$ & $\begin{array}{r}\text { uitzend-, } \\
\text { oproepkracht } \\
\%\end{array}$ & $\begin{array}{r}\text { loondienst } \\
\text { werkgever } \\
\%\end{array}$ & $\begin{array}{r}\text { gesubsidieerde } \\
\text { arbeid (WIW) } \\
\%\end{array}$ & $\begin{array}{r}\text { bedrijf } \\
\text { ouders/ } \\
\text { partner } \\
\%\end{array}$ & $\begin{array}{r}\text { eigen bedrijf/ } \\
\text { free-lance } \\
\%\end{array}$ \\
\hline
\end{tabular}

BBL niveau 1/2 (vervolg)

BB Opslag/magazijn

BB Horeca, instellingskeuken en contractcatering

BB Facilitaire dienstverlening

BB Verpleging en verzorging

BB Uiterlijke verzorging

\section{$B B L$ niveau 3/4}

ZB Bloemschikken

ZB Bouw

$Z B$ Grond-, water- en wegenbouw

ZB Constructie-, plaatwerken/pijpenbewerken

ZB Motorvoertuigen

ZB Energie- en informatietechniek

ZB Energietechniek

ZB Beheer, ontwerp en management (instal. techn)

ZB Installatie- service- en onderhoudstechniek

ZB Procestechniek

ZB Detailhandel/ambulante handel

ZB Horeca, instellingskeuken en contractcatering

ZB Horeca, instellingskeuken

ZB Verpleging en verzorging

ZB Uiterlijke verzorging

MKF Detailhandel/ambulante hande

MKF Verpleging en verzorging

MKF Sociaal-pedagogisch w

Specialist Energietechniek

Specialist Verpleging en verzorging

5
48
0
22
0

$\begin{array}{ll}5 & \\ 0 & \\ 0 & \\ 2 & \\ 0 & \end{array}$

90
50
100
76

1

84
97

97

3
2
7

0
0

0

0

0
15 
Tabel B3.3

Percentage werkende schoolverlaters met een flexibele aanstelling

Opleidingsrichting

VBO

IVBO Landbouw en natuurlijke omgeving

Landbouw en natuurlijke omgeving

Bouwtechniek

Mechanische techniek

Elektrotechniek

Motorvoertuigentechniek

Consumptieve techniek

Administratie

Verkoop

Verzorging

Uiterlijke verzorging

BOL niveau $1 / 2$

$\mathrm{AB}$ Beveiliging

BB Plantenteelt

BB Bloemschikken

BB Groene ruimte

BB Houtbewerking en woninginrichting

BB Detailhandel/ambulante handel

BB Horeca, instellingskeuken en contractcatering

BOL niveau $3 / 4$

ZB Plantenteelt

ZB Veehouderij

ZB Bloemschikken

$Z B$ Dierverzorging en veterinaire ondersteuning

ZB Paardenhouderij en paardensport

ZB Groene ruimte

ZB Graf techn, communicatie audiovisueel en multimedia

ZB Scheepvaart

ZB Bedrijfsadministratief

ZB Toerisme, recreatie en reizen

ZB Verpleging en verzorging

ZB Uiterlijke verzorging

KF Plantenteelt

KF Veehouderij

KF Levensmiddelentechnologie

KF Bloemschikken

KF Dierverzorging en veterinaire ondersteuning

KF Paardenhouderij en paardensport

KF Groene ruimte

MKF Bouw

MKF Houtbewerking en woninginrichting

MKF Grond-, water- en wegenbouw

MKF Beschermings- en afwerkingstechnieken

MKF Reclame, presentatie en communicatie

MKF Werktuigbouwkunde

MKF Motorvoertuigen

MKF Energie- en informatietechniek

MKF Informatietechniek

Graf. techn, communicatie, audiovisueel en multimedia

MKF Laboratoriumtechniek

MKF Scheepvaart

MKF Transport en logistiek

MKF Bedrijfsadministratief 
Tabel B3.3 (vervolg)

Percentage werkende schoolverlaters met een flexibele aanstelling

Opleidingsrichting

BOL niveau $3 / 4$ (vervolg)

MKF Detailhandel/ambulante handel $\quad 20$

MKF Horeca, instellingskeuken en contractcatering $\quad 20$

MKF Toerisme, recreatie en reizen $\quad 23$

$\begin{array}{ll}\text { MKF Assistenten gezondheidszorg } & 10\end{array}$

MKF Sport en bewegen $\quad 20$

MKF Verpleging en verzorging $\quad 4$

MKF Sociaal-pedagogisch werk algemeen $\quad 20$

MKF Sociaal-juridisch werk $\quad 26$

BBL niveau $1 / 2$

AB Beveiliging

$A B$ Detailhandel/ambulante handel

$A B$ Verpleging en verzorging $\quad 11$

BB Bloemschikken $\quad 4$

BB Groene ruimte 1

BB Bouw $\quad 12$

BB Houtbewerking en woninginrichting 14

BB Grond-, water en wegenbouw 11

BB Constructie-, plaatwerken/pijpenbewerken $\quad 22$

BB Montage/onderhoud/operationele techniek 20

BB Motorvoertuigen $r$

BB Energietechniek 13

BB Installatie-, service- en onderhoudstechniek 12

BB Wegvervoer $r$

BB Detailhandel/ambulante handel $r$

BB Opslag/magazijn $\quad 5$

BB Horeca, instellingskeuken en contractcatering $\quad 55$

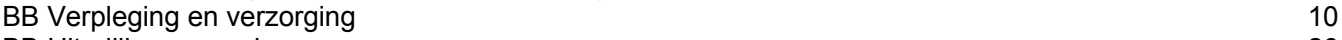

$\begin{array}{ll}\text { BB Uiterlijke verzorging } & 26\end{array}$

BBL niveau $3 / 4$

ZB Bloemschikken

2

ZB Bouw

ZB Grond-, water- en wegenbouw

ZB Constructie-, plaatwerken/pijpenbewerken

ZB Installatie-, service- en onderhoudstechniek

ZB Procestechniek

ZB Automatisering

ZB Detailhandel/ambulante handel

ZB Horeca, instellingskeuken en contractcatering

ZB Verpleging en verzorging $\quad 2$

ZB Uiterlijke verzorging $r$

MKF Detailhandel/ambulante handel 12

MKF Verpleging en verzorging $\quad 2$

MKF Sociaal-pedagogisch werk 11

$\begin{array}{ll}\text { Specialist Verpleging en verzorging } & 5\end{array}$

Zie toelichting bladzijde 26 
Tabel B3.4

Belangrijkste bedrijfsgroepen waarin schoolverlaters werkzaam zijn

IVBO Landbouw en natuurlijke omgeving

Dienstverl. tbv landb. (excl. veterin.dienst.)

Ov. gespec. detailh. in winkel

Niet-gespec. detailh. in winkel

Burgerl./utilit.;grond-/water-/wegenb. (excl. grondverz.)

VBO Landbouw en natuurlijke omgeving

Ov. gespec. detailh. in winkel

Dienstverl. tbv landb. (excl. veterin.dienst.)

Niet-gespec. detailh. in winkel

Overheidsdienst.

Welzijnszorg

Ov. dienstverlening

VBO Bouwtechniek

Afwerken gebouwen

Burgerl./utilit.;grond-/water-/wegenb. (excl. grondverz.)

VBO Mechanische techniek

Oppervlaktebehandeling/ov. metaalbewerking

Bouwrijp maken terreinen

Burgerl./utilit.;grond-/water-/wegenb. (excl. grondverz.)

Bouwinstallatie

Binnenvaart

Vervaard. ov. art. hout;vervaard. art. kurk/riet/vlechtw.

Vervaard. ijzer/staal/van ferro-legeringen (EGKS)

Vervaard. landbouwmach./-werkt.

Vervaard. kantoormachines/computers

Afwerken gebouwen

Handel in/repar. auto's (2)

Vervoer over weg

Verhuur transportmid. (excl. personenauto's)

Overheidsdienst.

VBO Elektrotechniek

Bouwinstallatie

Vervaard. ov. elektr. mach./appar./benodigdh.

VBO Motorvoertuigentechniek

Handel in/repar. auto's (1)

Handel in/repar. auto's/motorfiets.; benzineservicestations

Handel in/repar. auto's (2)

VBO Consumptieve techniek

Restaurants/cafetaria's/snackbars ed

Hotels/pensions/conferentie-oorden

Gespec. detailh. voed.-/genotmid. in winkel

\section{VBO Administratie}

Restaurants/cafetaria's/snackbars ed

Rechtsk. dienstverl./account./belastingconsul./holdings ed

Vervaard. kantoormachines/computers

Bouwinstallatie

Afwerken gebouwen

Niet-gespec. detailh. in winkel

Ov. gespec. detailh. in winkel

Detailh. niet in winkel 
VBO Administratie (vervolg)

Verhuur machines/werkt.

Welzijnszorg

\section{VBO Verkoop}

Ov. gespec. detailh. in winkel

Niet-gespec. detailh. in winkel

Gespec. detailh. voed.-/genotmid. in winkel

Telecommunicatie

\section{VBO Verzorging}

Welzijnszorg

Niet-gespec. detailh. in winkel

Ov. dienstverlening

Ov. gespec. detailh. in winkel

Hotels/pensions/conferentie-oorden

VBO Uiterlijke verzorging

Ov. dienstverlening

Ov. gespec. detailh. in winkel

\section{BOL AB Beveiliging}

Overheidsdienst.

Beveiliging/opsporing

BOL BB Plantenteelt

Dienstverl. tbv landb. (excl. veterin.dienst.)

Grooth. landbouwprod./lev. dieren

Akker-/tuinbouw

Bouwrijp maken terreinen

Burgerl./utilit.;grond-/water-/wegenb. (excl. grondverz.)

Ov. gespec. detailh. in winkel

BOL BB Bloemschikken

Ov. gespec. detailh. in winkel

Grooth. landbouwprod./lev. dieren

Handelsbemid.

Adviesbur. op gebied automat./systeemh.

Reiniging gebouwen/transportmid. ed

BOL BB Groene ruimte

Dienstverl. tbv landb. (excl. veterin.dienst.)

Ov. gespec. detailh. in winkel

BOL BB Houtbewerking en woninginrichting

Vervaard. meubels

Ov. gespec. detailh. in winkel

Reklamebureaus ed

BOL BB Detailhandel/ambulante handel

Ov. gespec. detailh. in winkel

Detailh. farmac./med. art./parfum/cosmet. in winkel 
BOL BB Horeca, instellingskeuken en contractcatering

Restaurants/cafetaria's/snackbars ed

Hotels/pensions/conferentie-oorden

Kampeerterreinen/ov. voorzien. recreat. verblijf n.e.g.

Gezondheidszorg

BOL BB Verpleging en verzorging

Welzijnszorg

Restaurants/cafetaria's/snackbars ed

Ov. gespec. detailh. in winkel

Overheidsdienst.

BOL ZB Plantenteelt

Akker-/tuinbouw

Ov. gespec. detailh. in winkel

Dienstverl. tbv landb. (excl. veterin.dienst.)

Bouwrijp maken terreinen

BOL ZB Veehouderij

Fokken/houden dieren

Dienstverl. tbv landb. (excl. veterin.dienst.)

Bouwrijp maken terreinen

Uitzendbur./uitleenbedr./arbeidsbemid./testen/werven/select.

BOL ZB Bloemschikken

Ov. gespec. detailh. in winkel

Niet-gespec. detailh. in winkel

BOL ZB Dierverzorging en veterinaire ondersteuning

Ov. gespec. detailh. in winkel

Cult. uitl.centra/openb. arch./musea/dieren-/plantentuin ed

Fokken/houden dieren

Drukkerijen/aanverwante activ.

Veterinaire diensten

Sport

BOL ZB Paardenhouderij en paardensport

Overig amusement/kunst

Sport

Fokken/houden dieren

Handel in/repar. motorfiets./onderd./accessoir. daarv.

Ov. gespec. detailh. in winkel

Hotels/pensions/conferentie-oorden

Restaurants/cafetaria's/snackbars ed

Kantines/catering

Reiniging gebouwen/transportmid. ed

Welzijnszorg

Ov. dienstverlening

BOL ZB Groene ruimte

Dienstverl. tbv landb. (excl. veterin.dienst.) 56

Ov. gespec. detailh. in winkel

ZB Graf. techn, communicatie, audiovisueel en multimedia Drukkerijen/aanverwante activ. 


\section{BOL ZB Scheepvaart}

Zeevaart

Overheidsdienst.

Zand-/grind-/kleiwinning

Scheepsbouw/-reparatie

Handelsbemid.

Uitzendbur./uitleenbedr./arbeidsbemid./testen/werven/select.

BOL ZB Bedrijfsadministratief

Rechtsk. dienstverl./account./belastingconsul./holdings ed

Vervaard. ov. mach./appar. voor alg. gebr.

Vervaard. kantoormachines/computers

Bouwinstallatie

Handel in/repar. auto's (1)

Grooth. intermediaire goederen (excl. agrar.)/afval/schroot

Post-/koeriersdiensten

Geldscheppende financ. instell.

Verzekeringsw./pensioenfonds. (excl. verpl. soc.verzek.)

Bemid. in/beheer onroerend goed

Uitzendbur./uitleenbedr./arbeidsbemid./testen/werven/select.

Verpl. soc. verzekeringen

\section{BOL ZB Toerisme, recreatie en reizen}

Reisorgan./-bemid.;informatieverstrek. op gebied toerisme 28

$\begin{array}{ll}\text { Hotels/pensions/conferentie-oorden } & 25\end{array}$

$\begin{array}{lr}\text { Ov. gespec. detailh. in winkel } & 10\end{array}$

Vervoer door lucht

Ov. dienstverl. tbv verv. n.e.g.

BOL ZB Verpleging en verzorging

Welzijnszorg

\section{BOL ZB Uiterlijke verzorging}

Ov. dienstverlening

Detailh. farmac./med. art./parfum/cosmet. in winkel

Geldscheppende financ. instell.

Ov. gespec. detailh. in winkel

\section{BOL KF Plantenteelt}

Akker-/tuinbouw

Dienstverl. tbv landb. (excl. veterin.dienst.)

Natuurwet. speur-/ontwikkelingsw.

Ov. gespec. detailh. in winkel

Grooth. landbouwprod./lev. dieren

BOL KF Veehouderij

Fokken/houden dieren

Ov. gespec. detailh. in winkel

Dienstverl. tbv landb. (excl. veterin.dienst.)

Akker-/tuinbouw

Veterinaire diensten

BOL KF Levensmiddelentechnologie

Grooth. voedings-/genotmid.

Post-/koeriersdiensten

Gespec. detailh. voed.-/genotmid. in winkel 
BOL KF Levensmiddelentechnologie (vervolg)

Groente-/fruitverwerking

Gezondheidszorg

Vervaard. diervoeder

Vervaard. dranken

Beveiliging/opsporing

BOL KF Bloemschikken

Ov. gespec. detailh. in winkel

BOL KF Dierverzorging en veterinaire ondersteuning

Veterinaire diensten

Ov. gespec. detailh. in winkel

Cult. uitl.centra/openb. arch./musea/dieren-/plantentuin ed

Niet-gespec. detailh. in winkel

Fokken/houden dieren

BOL KF Paardenhouderij en paardensport

Sport

Fokken/houden dieren

Rechtsk. dienstverl./account./belastingconsul./holdings ed

Restaurants/cafetaria's/snackbars ed

Veterinaire diensten

BOL KF Groene ruimte

Dienstverl. tbv landb. (excl. veterin.dienst.)

Architecten-/ingenieurs-/ov. techn.ontw.-/teken-/adviesbur.

Burgerl./utilit.;grond-/water-/wegenb. (excl. grondverz.)

Ov. gespec. detailh. in winkel

\section{BOL MKF Bouw}

Burgerl./utilit.;grond-/water-/wegenb. (excl. grondverz.)

Architecten-/ingenieurs-/ov. techn.ontw.-/teken-/adviesbur.

Bouwnijverheid

BOL MKF Houtbewerking en woninginrichting

Vervaard. meubels

Ov. gespec. detailh. in winkel

Ov. zakelijke dienstverl. n.e.g.

Afwerken gebouwen

BOL MKF Grond-, water- en wegenbouw

Burgerl./utilit.;grond-/water-/wegenb. (excl. grondverz.)

Architecten-/ingenieurs-/ov. techn.ontw.-/teken-/adviesbur.

BOL MKF Beschermings- en afwerkingstechnieken

Afwerken gebouwen

Ov. gespec. detailh. in winkel

BOL MKF Reclame, presentatie en communicatie

Reklamebureaus ed

Niet-gespec. detailh. in winkel

Ov. gespec. detailh. in winkel

Ov. zakelijke dienstverl. n.e.g.

BOL MKF Werktuigbouwkunde

Vervaard. prod. metaal (excl. mach./transportmid.) 
BOL MKF Motorvoertuigen

Handel in/repar. auto's (1)

Akker-/tuinbouw

Vervaard. prod. kunststof

Handel in/repar. auto's (2)

Handel in/repar. motorfiets./onderd./accessoir. daarv.

Voortgezet onderwijs

BOL MKF Energie- en informatietechniek

Bouwinstallatie

Ov. gespec. detailh. in winkel

Architecten-/ingenieurs-/ov. techn.ontw.-/teken-/adviesbur.

Vervaard. ov. voedingsmid.

Vervaard. ov. prod. metaal (excl. mach./transportmid.)

Vervaard. mach./appar.

Vervaard. rollend spoor-/tramwegmat.

Ov. zakelijke dienstverl.

Overheidsdienst.

Gezondheidszorg

Ov. recreatie

\section{BOL MKF Informatietechniek}

Ov. gespec. detailh. in winkel

Overheidsdienst.

Ov. dienstverl. op gebied automat.

Adviesbur. op gebied automat./systeemh.

Telecommunicatie

Computerservice-/informatietechnologiebur. ed

BOL MKF Graf. techn, communicatie, audiovisueel en multimedia Reklamebureaus ed

Drukkerijen/aanverwante activ.

Grooth. ov. consumentenart.

Uitgeverijen

Niet-gespec. detailh. in winkel

BOL MKF Laboratoriumtechniek

Gezondheidszorg

Overheidsdienst.

BOL MKF Scheepvaart

Scheepsbouw/-reparatie

Binnenvaart

Zeevaart

Overheidsdienst.

Vervaard. ov. transportmid. n.e.g.

Bouwrijp maken terreinen

Vervoer over weg

Vervoer over water

BOL MKF Transport en logistiek

Dienstverl. tbv vervoer

Binnenvaart

Vervoer over weg

Vervoer over water

Zeevaart

BOL MKF Bedrijfsadministratief

Rechtsk. dienstverl./account./belastingconsul./holdings ed 
BOL MKF Bedrijfsadministratief (vervolg)

Welzijnszorg

BOL MKF Commercieel

Geldscheppende financ. instell.

Activ. verzekeringsw./pensioenfonds.

Verzekeringsw./pensioenfonds. (excl. verpl. soc.verzek.)

Ov. gespec. detailh. in winkel

Uitzendbur./uitleenbedr./arbeidsbemid./testen/werven/select.

Verpl. soc. verzekeringen

BOL MKF Secretarieel

Hotels/pensions/conferentie-oorden

Reisorgan./-bemid.;informatieverstrek. op gebied toerisme

Grooth. intermediaire goederen (excl. agrar.)/afval/schroot

Rechtsk. dienstverl./account./belastingconsul./holdings ed

Openbaar bestuur

Ov. gespec. detailh. in winkel

Gezondheidszorg

BOL MKF Detailhandel/ambulante handel

Ov. gespec. detailh. in winkel

Niet-gespec. detailh. in winke

BOL MKF Horeca, instellingskeuken en contractcatering Hotels/pensions/conferentie-oorden

Restaurants/cafetaria's/snackbars ed

Cafes ed

Kantines/catering

BOL MKF Toerisme, recreatie en reizen

Reisorgan./-bemid.;informatieverstrek. op gebied toerisme

Hotels/pensions/conferentie-oorden

Kampeerterreinen/ov. voorzien. recreat. verblijf n.e.g.

BOL MKF Assistenten gezondheidszorg

Gezondheidszorg

Detailh. farmac./med. art./parfum/cosmet. in winkel

BOL MKF Sport en bewegen

Sport

Overheidsdienst.

Welzijnszorg

BOL MKF Verpleging en verzorging

Gezondheidszorg

BOL MKF Sociaal-pedagogisch werk algemeen

Welzijnszorg

BOL MKF Sociaal-juridisch werk

Uitzendbur./uitleenbedr./arbeidsbemid./testen/werven/select. 13

Openbaar bestuur

Overheidsdienst.

Welzijnszorg

Verpl. soc. verzekeringen

BBL AB Groene ruimte 
BBL AB Groene ruimte (vervolg)

Vervaard. ov. goederen n.e.g.

BBL AB Beveiliging

Beveiliging/opsporing

Overheidsdienst.

Openbaar bestuur

BBL AB Detailhandel/ambulante handel

Niet-gespec. detailh. in winkel

Ov. gespec. detailh. in winkel

Gespec. detailh. voed.-/genotmid. in winkel

Vervaard. meubels

Vervoer over weg

$B B L A B$ Verpleging en verzorging

Welzijnszorg

Gezondheidszorg

Gezondheids-/welzijnszorg

Ov. dienstverlening

\section{BBL BB Plantenteelt}

Akker-/tuinbouw

Natuurwet. speur-/ontwikkelingsw.

Dienstverl. tbv landb. (excl. veterin.dienst.)

Bouwrijp maken terreinen

Grooth. landbouwprod./lev. dieren

BBL BB Bloemschikken

Ov. gespec. detailh. in winkel

BBL BB Groene ruimte

Dienstverl. tbv landb. (excl. veterin.dienst.)

Openbaar bestuur

BBL BB Bouw

Burgerl./utilit.;grond-/water-/wegenb. (excl. grondverz.)

BBL BB Houtbewerking en woninginrichting

Vervaard. meubels

Ov. gespec. detailh. in winkel

Vervaard. timmerw.

Vervaard. ov. art. hout;vervaard. art. kurk/riet/vlechtw.

Jacht

Grooth. ov. consumentenart.

BBL BB Grond-, water en wegenbouw

Burgerl./utilit.;grond-/water-/wegenb. (excl. grondverz.)

Vervaard. ov. elektr. benodigdh. n.e.g.

Bouwnijverheid

Bouwinstallatie

Verhuur bouw-/sloopmachines met bedienend personeel

Geldscheppende financ. instell.

BBL BB Constructie-, plaatwerken/pijpenbewerken

Bouwinstallatie

Vervaard. metalen constructiew./ramen/deuren/kozijnen

Vervaard. ov. prod. metaal (excl. mach./transportmid.)

Vervaard. prod. metaal (excl. mach./transportmid.) 
BBL BB Constructie-, plaatwerken/pijpenbewerken (vervolg)

Overheidsdienst.

Vervaard. landbouwmach./-werkt.

Scheepsbouw/-reparatie

BBL BB Montage/onderhoud/operationele techniek

Vervaard. ov. chem. prod.

Vervaard. pulp/papier/karton

Vervaard. prod. kunststof

Vervaard. mach./appar.

Vervaard. ov. mach./appar. voor alg. gebr.

Vervaard. ov. mach./appar. voor specif. ind. activ.

Vervaard. kantoormachines/computers

Vervaard. elektr. lampen/buizen/van verlichtingsbenodigdh.

Handel in/repar. auto's (1)

Ov. gespec. detailh. in winkel

BBL BB Motorvoertuigen

Handel in/repar. auto's (1)

Ov. gespec. detailh. in winkel

Handel in/repar. auto's (2)

Handel in/repar. motorfiets./onderd./accessoir. daarv.

Grooth. ov. consumentenart.

Overheidsdienst.

\section{BBL BB Energietechniek}

Bouwinstallatie

Burgerl./utilit.;grond-/water-/wegenb. (excl. grondverz.)

Prod./distrib. elektriciteit/aardgas/stoom/warm water

BBL BB Installatie-, service- en onderhoudstechniek

BBL BB Procestechniek

Grooth. intermediaire goederen (excl. agrar.)/afval/schroot

Vervaard. ov. voedingsmid.

Vervaard. chem. prod.

Vervaard. basischemicalien

Vervaard. glas/glaswerk

Bouwinstallatie

BBL BB Wegvervoer

Vervoer over weg

Grooth. voedings-/genotmid.

Dienstverl. tbv vervoer

BBL BB Detailhandel/ambulante handel

Niet-gespec. detailh. in winkel

BBL BB Opslag/magazijn

Vervaard. prod. rubber

Vervaard. fietsen/motor-/bromfietsen/invalidenwag.

Grooth. ov. consumentenart.

Ov. gespec. detailh. in winkel

Vervaard. auto-onderd./-accessoir.

BBL BB Horeca, instellingskeuken en contractcatering

Restaurants/cafetaria's/snackbars ed 
BBL BB Facilitaire dienstverlening

Welzijnszorg

Gezondheidszorg

BBL BB Verpleging en verzorging

Welzijnszorg

Gezondheidszorg

BBL BB Uiterlijke verzorging

Ov. dienstverlening

Vervaard. zeep-,was-,reinig.-/onderhoudsmid.,parfum/cosmet.

Grooth. ov. consumentenart.

BBL ZB Bloemschikken

Ov. gespec. detailh. in winkel

BBL ZB Groene ruimte

Dienstverl. tbv landb. (excl. veterin.dienst.)

Openbaar bestuur

BBL ZB Bouw

Burgerl./utilit.;grond-/water-/wegenb. (excl. grondverz.)

BBL ZB Grond-, water- en wegenbouw

Burgerl./utilit.;grond-/water-/wegenb. (excl. grondverz.) 48

Bouwrijp maken terreinen 36

BBL ZB Constructie-, plaatwerken/pijpenbewerken

Vervaard. metalen constructiew./ramen/deuren/kozijnen

Akker-/tuinbouw

Vervaard. zeep-,was-,reinig.-/onderhoudsmid.,parfum/cosmet.

Overheidsdienst.

BBL ZB Motorvoertuigen

Handel in/repar. auto's (1)

Handel in/repar. auto's (2)

Vervaard. auto's

Overheidsdienst.

BBL ZB Energie- en informatietechniek

Bouwinstallatie

Ov. gespec. detailh. in winkel

Visverwerking

Vervaard. prod. kunststof

Vervaard. elektromot./elektr. generat./transformat.

Vervaard. rollend spoor-/tramwegmat.

Vervaard. vlieg-/ruimtevaart.

Burgerl./utilit.;grond-/water-/wegenb. (excl. grondverz.)

Repar. tbv partic. (niet auto's/motorfiets.)

Vervoer per spoor

Ov. dienstverl. op gebied automat.

Uitzendbur./uitleenbedr./arbeidsbemid./testen/werven/select.

Gezondheidszorg

BBL ZB Energietechniek

Bouwinstallatie

Prod./distrib. elektriciteit/aardgas/stoom/warm water

Verhuur onroerend goed

Burgerl./utilit.;grond-/water-/wegenb. (excl. grondverz.) 
BBL ZB Beheer, ontwerp en management (instal. techn)

Bouwinstallatie

BBL ZB Installatie-, service- en onderhoudstechniek

Bouwinstallatie

BBL ZB Procestechniek

Vervaard. pulp/papier/karton

Vervaard. ov. chem. prod.

Vervaard. prod. kunststof

Grooth. intermediaire goederen (excl. agrar.)/afval/schroot

Ov. gespec. detailh. in winkel

Ov. delfstoffenwinning

Vervaard. papier-/kartonw.

Vervaard. chem. prod.

Vervaard. zeep-,was-,reinig.-/onderhoudsmid.,parfum/cosmet.

Vervaard. tanks/reservoirs/ketels/radiat. centr. verwarm.

Vervaard. auto's

Vervaard. ov. goederen n.e.g.

Grooth. voedings-/genotmid.

Vervoer door lucht

Overheidsdienst.

BBL ZB Automatisering

Onderwijs

Uitgeverijen

Oppervlaktebehandeling/ov. metaalbewerking

Ov. gespec. detailh. in winkel

Computerservice-/informatietechnologiebur. ed

Adviesbur. op gebied automat./systeemh.

Ov. dienstverl. op gebied automat.

Openbaar bestuur

Overheidsdienst.

Gezondheidszorg

BBL ZB Detailhandel/ambulante handel

Ov. gespec. detailh. in winkel

Niet-gespec. detailh. in winkel

BBL ZB Horeca, instellingskeuken en contractcatering

Restaurants/cafetaria's/snackbars ed

BBL ZB Verpleging en verzorging

Welzijnszorg

Gezondheidszorg

Gezondheids-/welzijnszorg

BBL ZB Uiterlijke verzorging

Ov. dienstverlening

BBL MKF Bouw

Burgerl./utilit.;grond-/water-/wegenb. (excl. grondverz.)

Bouwnijverheid

BBL MKF Detailhandel/ambulante handel

Ov. gespec. detailh. in winkel

Niet-gespec. detailh. in winkel 
Tabel B3.4 (vervolg)

Belangrijkste bedrijfsgroepen waarin schoolverlaters werkzaam zijn

BBL MKF Detailhandel/ambulante handel (vervolg)

Vervaard. kleding/-toebehoren (excl. leer)

Grooth ov consumentenart.

Detailh. farmac./med. art./parfum/cosmet. in winkel

BBL MKF Verpleging en verzorging

Gezondheidszorg

Welzijnszorg

BBL MKF Sociaal-pedagogisch werk

Welzijnszorg

Gezondheidszorg

Gezondheids-/welzijnszorg

BBL Specialist Energietechniek

Bouwinstallatie

Prod./distrib. elektriciteit/aardgas/stoom/warm water

BBL Specialist Verpleging en verzorging

Welzijnszorg

Gezondheidszorg

Zie toelichting bladzijde 31 
Tabel B3.5

Belangrijkste beroepsgroepen waarin schoolverlaters werkzaam zijn

IVBO Landbouw en natuurlijke omgeving

Verkopers

Agrarische arbeider

Laders en lossers

Bouwvakkers

VBO Landbouw en natuurlijke omgeving

Verkopers

Agrarische arbeider

Hulpkrachten horeca en verzorging

Verzorgend personeel

Aspirant politieagenten, soldaten en beveiligingshulpkrachte

\section{VBO Bouwtechniek}

Bouwvakkers

Aannemers en installateurs

VBO Mechanische techniek

Metaalarbeiders

Laders en lossers

Weg- en waterbouwkundige arbeiders

Aannemers en installateurs

Bankwerkers en lassers

Bouwvakkers

Assembleurs

Aspirant politieagenten, soldaten en beveiligingshulpkrachte

Weg- en waterbouwkundige vakkrachten

Monteurs

Procesoperators

VBO Elektrotechniek

Elektromonteurs

Monteurs en controleurs elektrotechnische producten

Laders en lossers

Bouwvakkers

Verkopers

VBO Motorvoertuigentechniek

Monteurs

Assembleurs

Chauffeurs

Agrarische arbeider

VBO Consumptieve techniek

Hulpkrachten horeca en verzorging

Bakkers en slagers

VBO Administratie

Receptionisten en administratieve employés $\quad 43$

Hulpkrachten horeca en verzorging 21

Bouwvakkers

Aannemers en installateurs

Winkeliers

VBO Verkoop

Verkopers 


\section{VBO Verzorging}

$\begin{array}{ll}\text { Hulpkrachten horeca en verzorging } & 37\end{array}$

Verkopers

Verzorgend personeel

Verpleeghulpen en leerling-verpleegkundigen

Interieurverzorger

VBO Uiterlijke verzorging

Hulpkrachten horeca en verzorging $\quad 55$

Verkopers

BOL AB Beveiliging

Aspirant politieagenten, soldaten en beveiligingshulpkrachte $\quad 58$

Politieagenten, onderofficieren en beveiligingsemployés 11

Chauffeurs

BOL BB Plantenteelt

Landbouwmachinebestuurders en vissers $\quad 21$

Agrarische arbeider $\quad 20$

Weg- en waterbouwkundige vakkrachten $\quad 14$

Chauffeurs $\quad 10$

$\begin{array}{ll}\text { Laders en lossers } & 7\end{array}$

Bouwvakkers

Commercieel employés $\quad 6$

Milieuhygienisten en agrarisch vertegenwoordigers $\quad 6$

Verkopers

BOL BB Bloemschikken

Agrarische arbeider

Interieurverzorger

Agrarische vakkrachten

BOL BB Groene ruimte

Agrarische arbeider

Agrarische bedrijfshoofden

BOL BB Houtbewerking en woninginrichting

Aannemers en installateurs

Bouwvakkers

Verkopers

Confectie-arbeiders

BOL BB Detailhandel/ambulante handel

Verkopers

Winkeliers

Receptionisten en administratieve employés

BOL BB Horeca, instellingskeuken en contractcatering

Hulpkrachten horeca en verzorging

BOL BB Verpleging en verzorging

Verzorgend personeel

Hulpkrachten horeca en verzorging

Verkopers

Receptionisten en administratieve employés 
Belangrijkste beroepsgroepen waarin schoolverlaters werkzaam zijn

BOL ZB Plantenteelt

Agrarische arbeider

Verkopers

Landbouwmachinebestuurders en vissers

Monteurs

Agrarische bedrijfshoofden

Bouwvakkers

\section{BOL ZB Veehouderij}

Agrarische arbeider

Landbouwmachinebestuurders en vissers

Agrarische bedrijfshoofden

Weg- en waterbouwkundige vakkrachten

Verkopers

BOL ZB Bloemschikken

Verkopers

Agrarische arbeider

BOL ZB Dierverzorging en veterinaire ondersteuning

Verkopers

Agrarische arbeider

Agrarische vakkrachten

Chauffeurs

Hulpkrachten horeca en verzorging

BOL ZB Paardenhouderij en paardensport

Hulpkrachten horeca en verzorging

Interieurverzorger

Agrarische arbeider

Verkopers

Sportinstructeurs

Apothekersassistenten en medisch laboranten

BOL ZB Groene ruimte

Agrarische arbeider

Bouwvakkers

Agrarische bedrijfshoofden

Verkopers

BOL ZB Graf. techn, communicatie, audiovisueel en multimedia

Grafisch productiepersoneel

Grafische vakkrachten

Grafisch ontwerpers

Kantoorhulpen, inpakkers en colporteurs

Technisch-commercieel employés

BOL ZB Scheepvaart

Schippers en conducteurs

Chauffeurs

Laders en lossers

Landbouwmachinebestuurders en vissers

Monteurs

BOL ZB Bedrijfsadministratief

Boekhouders en secretaresses

Verzekeringsagenten

Commercieel employés 
BOL ZB Bedrijfsadministratief (vervolg)

Juridisch en fiscaal medewerkers

Assistent accountants

BOL ZB Toerisme, recreatie en reizen

Commercieel employés

Receptionisten en administratieve employés

Stewards

Hulpkrachten horeca en verzorging

Verkopers

BOL ZB Verpleging en verzorging

Verzorgend personeel

Verplegenden en doktersassistenten

Hulpkrachten horeca en verzorging

Ziekenverzorgenden

Verpleeghulpen en leerling-verpleegkundigen

BOL ZB Uiterlijke verzorging

Verzorgend personeel

Verkopers

Receptionisten en administratieve employés

BOL KF Plantenteelt

Agrarische arbeider

Agrarische bedrijfshoofden

Landbouwmachinebestuurders en vissers

Commercieel employés

BOL KF Veehouderij

Agrarische arbeider

Agrarische bedrijfshoofden

Verkopers

Landbouwmachinebestuurders en vissers

Verplegenden en doktersassistenten

BOL KF Levensmiddelentechnologie

Procesoperators

Laboranten

Chauffeurs

Verkopers

Verplegenden en doktersassistenten

Apothekersassistenten en medisch laboranten

BOL KF Bloemschikken

Verkopers

Receptionisten en administratieve employés

Agrarische vakkrachten

BOL KF Dierverzorging en veterinaire ondersteuning

Verplegenden en doktersassistenten

Verkopers

Agrarische arbeider

Receptionisten en administratieve employés

Agrarische vakkrachten

Winkeliers

BOL KF Paardenhouderij en paardensport 
BOL KF Paardenhouderij en paardensport (vervolg)

Verplegenden en doktersassistenten

Receptionisten en administratieve employés

Hulpkrachten horeca en verzorging

Agrarische bedrijfshoofden

Boekhouders en secretaresses

BOL KF Groene ruimte

Bouwvakkers

Agrarische arbeider

Agrarische bedrijfshoofden

Aannemers en installateurs

Weg- en waterbouwkundige vakkrachten

Agrarische vakkrachten

BOL MKF Bouw

Aannemers en installateurs

Bouwvakkers

Architecten en bouwkundig projectleiders

BOL MKF Houtbewerking en woninginrichting

Aannemers en installateurs

Verkopers

Monteurs

Confectie-arbeiders

BOL MKF Grond-, water- en wegenbouw

Weg- en waterbouwkundige vakkrachten

Weg- en waterbouwkundige arbeiders

Aannemers en installateurs

BOL MKF Beschermings- en afwerkingstechnieken Aannemers en installateurs

Verkopers

Bouwvakkers

Winkeliers

Technisch-commercieel employés

Monteurs

BOL MKF Reclame, presentatie en communicatie Technisch-commercieel employés

BOL MKF Werktuigbouwkunde

Aannemers en installateurs

Monteurs

Bankwerkers en lassers

Metaalarbeiders

BOL MKF Motorvoertuigen

Monteurs

Agrarische arbeider

Assembleurs

Aannemers en installateurs

Commercieel employés

Docenten landbouw en techniek (2e en $3 e$ gr.)

Materiaalkundigen 
BOL MKF Energie- en informatietechniek

Elektromonteurs

Elektronicamonteurs

Monteurs en controleurs elektrotechnische producten

Bankwerkers en lassers

Programmeurs

Boekhouders en secretaresses

BOL MKF Informatietechniek

Programmeurs

Elektromonteurs

Systeemanalisten

Elektronicamonteurs

Politieagenten, onderofficieren en beveiligingsemployés

Commercieel employés

BOL MKF Graf. techn, communicatie, audiovisueel en multimedia

Grafisch ontwerpers

Grafische vakkrachten

Grafisch productiepersoneel

Laders en lossers

Verzekeringsagenten

Elektronicamonteurs

Productieplanners

Commercieel employés

BOL MKF Laboratoriumtechniek

Apothekersassistenten en medisch laboranten

Laboranten

Verpleeghulpen en leerling-verpleegkundigen

BOL MKF Scheepvaart

Vliegers, scheepskapiteins en leidinggevenden transport

Monteurs

Chauffeurs

Schippers en conducteurs

Administratieve transportemployés

Receptionisten en administratieve employés

We rktuigbouwkundig ontwerpers en hoofden technische dienst

BOL MKF Transport en logistiek

Administratieve transportemployés

Commercieel employés

Receptionisten en administratieve employés $\quad 18$

Laders en lossers

Productieplanners

BOL MKF Bedrijfsadministratief

Boekhouders en secretaresses

Assistent accountants

Receptionisten en administratieve employés

Verkopers

BOL MKF Commercieel

Commercieel employés

Boekhouders en secretaresses

Receptionisten en administratieve employés

Verzekeringsagenten

Activiteitenbegeleiders en medewerkers arbeidsbemiddeling 


\section{BOL MKF Secretariee}

Boekhouders en secretaresses $\quad 43$

Receptionisten en administratieve employés $\quad 24$

Commercieel employés $\quad 16$

BOL MKF Detailhandel/ambulante handel

Winkeliers

Commercieel employés

Receptionisten en administratieve employés

Hulpkrachten horeca en verzorging

BOL MKF Horeca, instellingskeuken en contractcatering

Hulpkrachten horeca en verzorging

Receptionisten en administratieve employés

Bedrijfshoofden horeca

Boekhouders en secretaresses

Verzorgend personeel

BOL MKF Toerisme, recreatie en reizen

Commercieel employés

Receptionisten en administratieve employés

Boekhouders en secretaresses

BOL MKF Assistenten gezondheidszorg

Verplegenden en doktersassistenten

\section{BOL MKF Sport en bewegen}

Sportinstructeurs

Activiteitenbegeleiders en medewerkers arbeidsbemiddeling Aspirant politieagenten, soldaten en beveiligingshulpkrachte

Therapeuten en verpleegkundigen

BOL MKF Verpleging en verzorging

Verplegenden en doktersassistenten

Verzorgend personeel

Activiteitenbegeleiders en medewerkers arbeidsbemiddeling

BOL MKF Sociaal-pedagogisch werk algemeen

Verzorgend personeel

Activiteitenbegeleiders en medewerkers arbeidsbemiddeling

Hulpkrachten horeca en verzorging

Therapeuten en verpleegkundigen

BOL MKF Sociaal-juridisch werk

Boekhouders en secretaresses

Receptionisten en administratieve employés

Activiteitenbegeleiders en medewerkers arbeidsbemiddeling

Sociaal-cultureel werkers

Verzekeringsagenten

Juridisch, bestuurlijk medewerkers

BBL AB Groene ruimte

Agrarische arbeider 
BBL AB Beveiliging

Aspirant politieagenten, soldaten en beveiligingshulpkrachte Kantoorhulpen, inpakkers en colporteurs

Mechanisch operators

BBL AB Detailhandel/ambulante handel

Verkopers

Laders en lossers

Vakkenvuller

Chauffeurs

$B B L A B$ Verpleging en verzorging

Verzorgend personeel

Hulpkrachten horeca en verzorging

Verpleeghulpen en leerling-verpleegkundigen

Ziekenverzorgenden

Activiteitenbegeleiders en medewerkers arbeidsbemiddeling

BBL BB Plantenteelt

Agrarische arbeider

Landbouwmachinebestuurders en vissers

\section{BBL BB Bloemschikken}

Verkopers

Agrarische vakkrachten

Agrarische arbeider

BBL BB Groene ruimte

Agrarische arbeider

Bouwvakkers

Agrarische bedrijfshoofden

BBL BB Bouw

Aannemers en installateurs

BBL BB Houtbewerking en woninginrichting

Aannemers en installateurs

Bouwvakkers

Confectie-arbeiders

Monteurs

Verkopers

BBL BB Grond-, water en wegenbouw

Weg- en waterbouwkundige arbeiders

Weg- en waterbouwkundige vakkrachten

Monteurs en controleurs elektrotechnische producten

Commercieel employés

BBL BB Constructie-, plaatwerken/pijpenbewerken

Metaalarbeiders

Bankwerkers en lassers

Aannemers en installateurs

Bouwvakkers

Aspirant politieagenten, soldaten en beveiligingshulpkrachte

BBL BB Montage/onderhoud/operationele techniek

Mechanisch operators

Monteurs

Productiemedewerker 
BBL BB Montage/onderhoud/operationele techniek (vervolg)

Elektromonteurs

Bouwvakkers

Metaalarbeiders

Assembleurs

Procesoperators

BBL BB Motorvoertuigen

Monteurs

BBL BB Energietechniek

Elektromonteurs

Monteurs

BBL BB Installatie-, service- en onderhoudstechniek

Aannemers en installateurs

Bouwvakkers

Elektromonteurs

Monteurs

BBL BB Procestechniek

Mechanisch operators

Procesoperators

Monteurs

Productiemedewerker

Productieplanners

BBL BB Wegvervoer

Chauffeurs

BBL BB Detailhandel/ambulante handel

Verkopers

Winkeliers

Aspirant politieagenten, soldaten en beveiligingshulpkrachte

BBL BB Opslag/magazijn

Laders en lossers

Chauffeurs

Kantoorhulpen, inpakkers en colporteurs

Productiemedewerker

Verkopers

Productieplanners

Boekhouders en secretaresses

BBL BB Horeca, instellingskeuken en contractcatering

Hulpkrachten horeca en verzorging

BBL BB Facilitaire dienstverlening

Hulpkrachten horeca en verzorging

Verpleeghulpen en leerling-verpleegkundigen

Verplegenden en doktersassistenten

Verzorgend personeel

BBL BB Verpleging en verzorging

Verzorgend personeel

Hulpkrachten horeca en verzorging

Verpleeghulpen en leerling-verpleegkundigen

Ziekenverzorgenden 
BBL BB Uiterlijke verzorging

Verzorgend personeel

Productiemedewerker

Verkopers

Hulpkrachten horeca en verzorging

BBL ZB Bloemschikken

Verkopers

Agrarische vakkrachten

Agrarische arbeider

BBL ZB Groene ruimte

Bouwvakkers

Agrarische arbeider

Agrarische bedrijfshoofden

BBL ZB Bouw

Aannemers en installateurs

Boumvakkers

BBL ZB Grond-, water- en wegenbouw

Weg- en waterbouwkundige vakkrachten

BBL ZB Constructie-, plaatwerken/pijpenbewerken

Metaalarbeiders

Monteurs

Aannemers en installateurs

BBL ZB Motorvoertuigen

BBL ZB Energie- en informatietechniek

Elektromonteurs

Monteurs en controleurs elektrotechnische producten $\quad 13$

$\begin{array}{ll}\text { Weg- en waterbouwkundige arbeiders } & 7\end{array}$

Verkopers

Elektronicamonteurs

Procesoperators

BBL ZB Energietechniek

Elektromonteurs

Monteurs en controleurs elektrotechnische producten

Aannemers en installateurs

Elektronicamonteurs

BBL ZB Beheer, ontwerp en management (instal. techn)

Aannemers en installateurs

Monteurs

Bouwvakkers

Grafisch productiepersoneel

Elektromonteurs

BBL ZB Installatie-, service- en onderhoudstechniek

Aannemers en installateurs 
BBL ZB Procestechniek

Procesoperators

Mechanisch operators

BBL ZB Automatisering

Programmeurs

Elektronicamonteurs

Hoofden technische dienst

Onderwijskundig medewerkers

BBL ZB Detailhandel/ambulante handel

Verkopers

Winkeliers

Receptionisten en administratieve employés

BBL ZB Horeca, instellingskeuken en contractcatering

Verzorgend personeel

Hulpkrachten horeca en verzorging

BBL ZB Verpleging en verzorging

Verzorgend personeel

Ziekenverzorgenden

Hulpkrachten horeca en verzorging

BBL ZB Uiterlijke verzorging

Verzorgend personeel

BBL MKF Bouw

Aannemers en installateurs

Bouwvakkers

Commercieel employés

BBL MKF Detailhandel/ambulante handel

Winkeliers

Verkopers

Grafisch productiepersoneel

Commercieel employés

Hulpkrachten horeca en verzorging

BBL MKF Verpleging en verzorging

Verplegenden en doktersassistenten

BBL MKF Sociaal-pedagogisch werk

Activiteitenbegeleiders en medewerkers arbeidsbemiddeling $\quad 60$

Verzorgend personeel

Hulpkrachten horeca en verzorging

BBL Specialist Energietechniek

Elektromonteurs

Aannemers en installateurs

BBL Specialist Verpleging en verzorging

Verzorgend personeel

Activiteitenbegeleiders en medewerkers arbeidsbemiddeling

Ziekenverzorgenden

Docenten exacte, medische en verzorgende vakken (2e en $3 e \mathrm{gr}$

Docenten landbouw en techniek (2e en $3 e$ gr.)

Zie ook toelichting bladzijde 36 
Tabel B3.6

Grootte van de organisatie waarin schoolverlaters werkzaam zijn

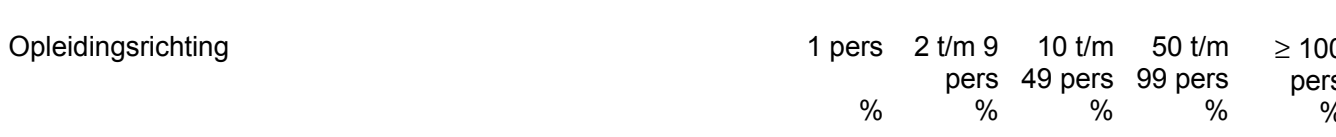

VBO

IVBO Landbouw en natuurlijke omgeving

Landbouw en natuurlijke omgeving

Bouwtechniek

Mechanische techniek

Elektrotechniek

Motorvoertuigentechniek

Consumptieve techniek

Administratie

Verkoop

Verzorging

Uiterlijke verzorging

BOL niveau $1 / 2$

$\mathrm{AB}$ Beveiliging

BB Plantenteelt

BB Bloemschikken

BB Groene ruimte

BB Houtbewerking en woninginrichting

BB Detailhandel/ambulante handel

BB Horeca, instellingskeuken en contractcatering

BB Verpleging en verzorging

$\begin{array}{rrrrr}0 & 35 & 36 & 9 & 20 \\ 2 & 29 & 31 & 8 & 30 \\ 2 & 27 & 46 & 9 & 16 \\ 0 & 40 & 30 & 15 & 15 \\ 0 & 10 & 28 & 10 & 52 \\ 0 & 36 & 36 & 9 & 18 \\ 0 & 21 & 46 & 4 & 29 \\ 7 & 36 & 43 & 0 & 14 \\ 0 & 18 & 50 & 14 & 18 \\ 0 & 21 & 20 & 8 & 51 \\ 0 & 40 & 41 & 0 & 18\end{array}$

\section{BOL niveau $3 / 4$}

ZB Plantenteelt

ZB Veehouderij

ZB Bloemschikken

ZB Dierverzorging en veterinaire ondersteuning

ZB Paardenhouderij en paardensport

ZB Groene ruimte

ZB Graf. techn, communicatie, audiovisueel en multimedia

ZB Scheepvaart

ZB Bedrijfsadministratief

ZB Toerisme, recreatie en reizen

$Z B$ Verpleging en verzorging

ZB Uiterlijke verzorging

KF Plantenteelt

KF Veehouderij

KF Levensmiddelentechnologie

KF Bloemschikken

KF Dierverzorging en veterinaire ondersteuning

KF Paardenhouderij en paardensport

KF Groene ruimte

MKF Bouw

MKF Houtbewerking en woninginrichting

MKF Grond-, water- en wegenbouw

MKF Beschermings- en afwerkingstechnieken

MKF Reclame, presentatie en communicatie

MKF Werktuigbouwkunde

MKF Motorvoertuigen

MKF Energie- en informatietechniek

MKF Informatietechniek

MKF Graf. techn, communicatie, audiovisueel en multimedia

MKF Laboratoriumtechniek

MKF Scheepvaart

MKF Transport en logistiek

MKF Bedrijfsadministratief

$\begin{array}{rrrrr}0 & 2 & 16 & 5 & 77 \\ 0 & 30 & 57 & 0 & 13 \\ 0 & 34 & 54 & 0 & 11 \\ 5 & 56 & 29 & 10 & 0 \\ 0 & 40 & 17 & 3 & 40 \\ 0 & 29 & 38 & 0 & 33 \\ 0 & 24 & 51 & 5 & 19 \\ 5 & 12 & 16 & 7 & 60\end{array}$

$\begin{array}{rrrrr}7 & 52 & 31 & 2 & 7 \\ 14 & 36 & 28 & 10 & 12 \\ 1 & 36 & 25 & 13 & 25 \\ 2 & 36 & 23 & 11 & 28 \\ 0 & 42 & 17 & 34 & 8 \\ 5 & 50 & 22 & 9 & 15 \\ 0 & 47 & 40 & 13 & 0 \\ 0 & 54 & 8 & 12 & 26 \\ 0 & 11 & 44 & 11 & 33 \\ 0 & 7 & 34 & 7 & 51 \\ 1 & 0 & 7 & 9 & 84 \\ 4 & 50 & 17 & 15 & 13 \\ 0 & 46 & 28 & 5 & 21 \\ 10 & 39 & 24 & 5 & 22 \\ 5 & 8 & 15 & 8 & 64 \\ 0 & 41 & 39 & 2 & 18 \\ 2 & 33 & 39 & 2 & 23 \\ 0 & 60 & 34 & 7 & 0 \\ 1 & 36 & 22 & 13 & 28 \\ 4 & 17 & 19 & 16 & 44 \\ 9 & 34 & 32 & 9 & 16 \\ 0 & 4 & 24 & 8 & 64 \\ 4 & 44 & 34 & 0 & 19 \\ 2 & 22 & 33 & 12 & 31 \\ 0 & 18 & 41 & 5 & 36 \\ 0 & 28 & 39 & 6 & 28 \\ 0 & 6 & 19 & 13 & 63 \\ 0 & 20 & 33 & 7 & 40 \\ 0 & 32 & 35 & 3 & 30 \\ 1 & 3 & 16 & 8 & 72 \\ 0 & 7 & 7 & 0 & 86 \\ 2 & 4 & 35 & 2 & 57 \\ 0 & 10 & 39 & 17 & 34\end{array}$


Tabel B3.6 (vervolg)

Grootte van de organisatie waarin schoolverlaters werkzaam zijn

\begin{tabular}{lrrrr}
\hline Opleidingsrichting & 1 pers & $2 \mathrm{t} / \mathrm{m} 9$ & $10 \mathrm{t} / \mathrm{m}$ & $50 \mathrm{t} / \mathrm{m}$ \\
$\%$ & $\begin{array}{r}\text { pers } \\
\%\end{array}$ & $\begin{array}{r}49 \text { pers } \\
\%\end{array}$ & $\begin{array}{r}99 \\
\%\end{array}$ & $\begin{array}{r}\text { pers } \\
\text { pers } \\
\%\end{array}$
\end{tabular}

BOL niveau 3/4 (vervolg)

MKF Commercieel

MKF Secretarieel

MKF Detailhandel/ambulante handel

MKF Horeca, instellingskeuken en contractcatering

MKF Toerisme, recreatie en reizen

MKF Assistenten gezondheidszorg

MKF Sport en bewegen

MKF Verpleging en verzorging

MKF Sociaal-pedagogisch werk algemeen

MKF Sociaal-juridisch werk

BBL niveau $1 / 2$

AB Groene ruimte

$A B$ Beveiliging

$A B$ Detailhandel/ambulante handel

$A B$ Verpleging en verzorging

BB Plantenteelt

BB Bloemschikken

BB Groene ruimte

BB Bouw

BB Houtbewerking en woninginrichting

BB Grond-, water en wegenbouw

BB Constructie-, plaatwerken/pijpenbewerken

BB Montage/onderhoud/operationele techniek

BB Motorvoertuigen

BB Energietechniek

BB Installatie-, service- en onderhoudstechniek

BB Procestechniek

BB Wegvervoer

BB Detailhandel/ambulante handel

BB Opslag/magazijn

BB Horeca, instellingskeuken en contractcatering

BB Facilitaire dienstverlening

BB Verpleging en verzorging

BB Uiterlijke verzorging

$\begin{array}{rrrrr}0 & 13 & 27 & 7 & 53 \\ 0 & 11 & 23 & 17 & 49 \\ 0 & 14 & 25 & 8 & 53 \\ 0 & 10 & 35 & 12 & 43 \\ 0 & 18 & 17 & 13 & 52 \\ 2 & 43 & 39 & 3 & 13 \\ 0 & 8 & 42 & 11 & 38 \\ 2 & 1 & 4 & 2 & 92 \\ 1 & 7 & 24 & 13 & 55 \\ 0 & 9 & 4 & 9 & 78\end{array}$

$B B L$ niveau $3 / 4$

ZB Bloemschikken

ZB Groene ruimte

ZB Bouw

ZB Grond-, water- en wegenbouw

ZB Constructie-, plaatwerken/pijpenbewerken

ZB Motorvoertuigen

ZB Energie- en informatietechniek

ZB Energietechniek

ZB Beheer, ontwerp en management (instal. techn)

ZB Installatie-, service- en onderhoudstechniek

ZB Procestechniek

ZB Automatisering

ZB Detailhandel/ambulante handel

ZB Horeca, instellingskeuken en contractcatering

$Z B$ Verpleging en verzorging

ZB Uiterlijke verzorging

MKF Bouw

MKF Detailhandel/ambulante handel

MKF Verpleging en verzorging

MKF Sociaal-pedagogisch werk 
Tabel B3.6 (vervolg)

Grootte van de organisatie waarin schoolverlaters werkzaam zijn

Opleidingsrichting

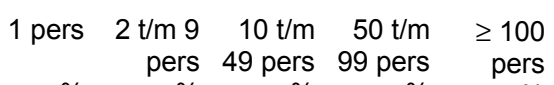

$\% \quad \% \quad \% \quad \% \quad \%$

BBL niveau 3/4 (vervolg)

Specialist Energietechniek

Specialist Verpleging en verzorging

$\begin{array}{lllll}0 & 0 & 18 & 5 & 77\end{array}$

Zie ook toelichting bladzijde 38 
Tabel B3.7

Beloning van werkende schoolverlaters

Opleidingsrichting

gemiddeld bruto

gemiddeld bruto

maandloon

uurloon

VBO

IVBO Landbouw en natuurlijke omgeving

4,57

Landbouw en natuurlijke omgeving

672

662

4,57

Bouwtechniek

$685-4,55$

Mechanische techniek

710

4,52

Elektrotechniek

$595 \quad 4,09$

Motorvoertuigentechniek

4,11
4,63

Consumptieve techniek

655

Administratie

689

4,88

Verkoop

Verzorging

550

4,88
3,79

Uiterlijke verzorging

4,50

$543 \quad 4,14$

BOL niveau $1 / 2$

AB Beveiliging

BB Plantenteelt

$1.172 \quad 7,29$

BB Bloemschikken

1.090

6,34

BB Groene ruimte

$658 \quad 5,05$

BB Houtbewerking en woninginrichting

1.004

6,25

BB Detailhandel/ambulante handel

1.157

6,89

BB Horeca, instellingskeuken en contractcatering

874

5,94

$B B$ Verpleging en verzorging

6,69

BOL niveau $3 / 4$

ZB Plantenteelt

ZB Veehouderij

ZB Bloemschikken

ZB Dierverzorging en veterinaire ondersteuning

997

7,00

ZB Paardenhouderij en paardensport

ZB Groene ruimte

ZB Graf. techn, communicatie, audiovisueel en multimedia

958

6,82

1.134

6,79

1.018

5,70
6,54

841
927

723

5,44

$1.228 \quad 7,61$

ZB Scheepvaart

1.161

7,18

ZB Bedrijfsadministratief

9,06

ZB Toerisme, recreatie en reizen

1.831
1.359

8,75

ZB Verpleging en verzorging

ZB Uiterlijke verzorging

KF Plantenteelt

1.257

7,97

$1.251 \quad 8,66$

$\begin{array}{ll}789 & 6,00\end{array}$

$1.333 \quad 8,34$

KF Veehouderij

8,34

KF Levensmiddelentechnologie

1.264

8,72

KF Bloemschikken

KF Dierverzorging en veterinaire ondersteuning

1.388

$\begin{array}{rl}1.023 & 6,71 \\ 922 & 6,20\end{array}$

$\begin{array}{ll}1.019 & 7,83 \\ 1.360 & 8,68\end{array}$

KF Paardenhouderij en paardensport

7,83
8,68
9,82

ruimte

1.360

MKF Bouw

MKF Houtbewerking en woninginrichting

1.615

$\begin{array}{ll}1.615 & 8,78 \\ 1.471 & 8,82\end{array}$

MKF Grond-, water- en wegenbouw

MKF Beschermings- en afwerkingstechnieken

8,95

$\begin{array}{ll}1.266 & 8,95 \\ 1.228 & 7,78\end{array}$

MKF Reclame, presentatie en communicatie

7,78
8,67

MKF Werktuigbouwkunde

1.454

$\begin{array}{ll}1.208 & 8,72 \\ 1.327 & 8,08\end{array}$

MKF Motorvoertuigen

Energie- en informatietechniek

$\begin{array}{ll}1.471 & 8,86 \\ 1.407 & 8,54\end{array}$

MKF Graf. techn, communicatie, audiovisueel en multimedia

8,54
9,87

MKF Laboratoriumtechniek

1.559

9,42
8,91

MKF Scheepvaart

2.226

Transport en logistiek

1.106

7,59 
Tabel B3.7 (vervolg)

Beloning van werkende schoolverlaters

Opleidingsrichting

gemiddeld bruto

maandloon

$€$ gemiddeld bruto

uurloon

BOL niveau 3/4 (vervolg)

MKF Commercieel

MKF Secretarieel

MKF Detailhandel/ambulante handel

MKF Horeca, instellingskeuken en contractcatering

MKF Toerisme, recreatie en reizen

MKF Assistenten gezondheidszorg

MKF Sport en bewegen

MKF Verpleging en verzorging

MKF Sociaal-pedagogisch werk algemeen

MKF Sociaal-juridisch werk

$\begin{array}{rr}1.299 & 8,00 \\ 1.307 & 7,96 \\ 1.037 & 6,86 \\ 1.422 & 9,08 \\ 1.288 & 8,06 \\ 1.168 & 7,75 \\ 1.460 & 10,11 \\ 1.459 & 9,75 \\ 1.032 & 8,54 \\ 1.637 & 11,00\end{array}$

BBL niveau $1 / 2$

AB Groene ruimte

$A B$ Beveiliging

$A B$ Detailhandel/ambulante handel

$A B$ Verpleging en verzorging

BB Plantenteelt

BB Bloemschikken

BB Groene ruimte

BB Bouw

BB Houtbewerking en woninginrichting

BB Grond-, water en wegenbouw

$1.162 \quad 7,44$

$\begin{array}{rr}1.162 & 7,44 \\ 1.597 & 10,14\end{array}$

$710 \quad 5,08$

$1.169 \quad 9,32$

$\begin{array}{ll}1.234 & 7,52\end{array}$

$786 \quad 5,28$

$1.377 \quad 8,48$

$1.417 \quad 8,61$

$1.071 \quad 6,58$

$1.318 \quad 8,22$

$1.274 \quad 7,51$

$1.335 \quad 8,23$

$1.272 \quad 7,91$

$1.259 \quad 7,48$

$1.291 \quad 7,60$

$2.231 \quad 14,24$

$1.407 \quad 7,90$

$799 \quad 5,44$

$1.482 \quad 9,20$

$1.034 \quad 6,93$

$898 \quad 8,90$

$1.122 \quad 10,02$

$897 \quad 6,19$

BB Uiterlijke verzorging

BBL niveau $3 / 4$

ZB Bloemschikken

ZB Groene ruimte

ZB Bouw

ZB Grond-, water- en wegenbouw

985

6,39

1.638

10,19

1.902

11,07

$1.466 \quad 9,26$

$1.737 \quad 10,75$

ZB Constructie-, plaatwerken/pijpenbewerken

10,75
9,57

$\begin{array}{rr}1.586 & 9,57 \\ 1.799 & 10,79\end{array}$

ZB Energie- en informatietechniek

10,79
9,02

$\begin{array}{rr}.533 & 9,02 \\ 998 & 12,05\end{array}$

ZB Beheer, ontwerp en management (instal. techn)

12,05
9,53

$\begin{array}{rr}1.590 & 9,53 \\ 398 & 15,61\end{array}$

ZB Procestechniek

ZB Automatisering

ZB Detailhandel/ambulante handel

$\begin{array}{rr}1.617 & 15,61 \\ 981 & 9,98 \\ 1.492 & 6,36\end{array}$

$1.492 \quad 8,88$

ZB Horeca, instellingskeuken en contractcatering

8,88
10,96

Verpleging en verzorging

1.376

ZB Uiterlijke verzorging

MKF Bouw

MKF Detailhandel/ambulante handel

$\begin{array}{rr}950 & 6,50 \\ 2.007 & 11,86 \\ 1.145 & 7,43\end{array}$

MKF Verpleging en verzorging

MKF Sociaal-pedagogisch werk

11,15

12,61 
Tabel B3.7 (vervolg)

Beloning van werkende schoolverlaters

Opleidingsrichting

gemiddeld bruto

gemiddeld bruto

maandloon

uurloon

BBL niveau 3/4 (vervolg)

Specialist Energietechniek

2.200

12,89

Specialist Verpleging en verzorging

1.428

12,73

Zie ook toelichting bladzijde 40 
Tabel B3.8

Vereist opleidingsniveau voor de huidige functie volgens de werkgever

\begin{tabular}{lrrr}
\hline Opleidingsrichting & $\begin{array}{r}\text { lager } \\
\%\end{array}$ & $\begin{array}{r}\text { zelfde } \\
\%\end{array}$ & $\begin{array}{r}\text { hoger } \\
\%\end{array}$ \\
\hline VBO & & & \\
IVBO Landbouw en natuurlijke omgeving & 27 & 28 & 45 \\
Landbouw en natuurlijke omgeving & 15 & 53 & 32 \\
Bouwtechniek & 12 & 42 & 46 \\
Mechanische techniek & 20 & 50 & 30 \\
Elektrotechniek & 19 & 58 & 23 \\
Motorvoertuigentechniek & 5 & 62 & 33 \\
Consumptieve techniek & 5 & 33 & 62 \\
Administratie & 23 & 54 & 23 \\
Verkoop & 17 & 56 & 28 \\
Verzorging & 13 & 60 & 27 \\
Uiterlijke verzorging & 5 & 48 & 47
\end{tabular}

BOL niveau $1 / 2$

AB Beveiliging

BB Plantenteelt

BB Bloemschikken

BB Groene ruimte

BB Houtbewerking en woninginrichting

BB Detailhandel/ambulante handel

BB Horeca, instellingskeuken en contractcatering

BB Verpleging en verzorging

$\begin{array}{rrr}82 & 16 & 2 \\ 62 & 38 & \\ 62 & 35 & 2 \\ 45 & 50 & 5 \\ 20 & 70 & 10 \\ 65 & 20 & 15 \\ 34 & 25 & 40 \\ 34 & 49 & 17\end{array}$

BOL niveau $3 / 4$

ZB Plantenteelt

ZB Veehouderij

ZB Bloemschikken

ZB Dierverzorging en veterinaire ondersteuning

ZB Paardenhouderij en paardensport

ZB Groene ruimte

ZB Graf. techn, communicatie, audiovisueel en multimedia

ZB Scheepvaart

ZB Bedrijfsadministratief

ZB Toerisme, recreatie en reizen

$Z B$ Verpleging en verzorging

ZB Uiterlijke verzorging

KF Plantenteelt

KF Veehouderij

KF Levensmiddelentechnologie

KF Bloemschikken

KF Dierverzorging en veterinaire ondersteuning

KF Paardenhouderij en paardensport

KF Groene ruimte

MKF Bouw

MKF Houtbewerking en woninginrichting

MKF Grond-, water- en wegenbouw

MKF Beschermings- en afwerkingstechnieken

MKF Reclame, presentatie en communicatie

MKF Werktuigbouwkunde

MKF Motorvoertuigen

MKF Energie- en informatietechniek

MKF Informatietechniek

MKF Graf. techn, communicatie, audiovisueel en multimedia

MKF Laboratoriumtechniek

MKF Scheepvaart

MKF Transport en logistiek

MKF Bedrijfsadministratief

$\begin{array}{rrr}63 & 37 & \\ 74 & 26 & \\ 63 & 37 & \\ 62 & 38 & \\ 92 & 8 & \\ 67 & 33 & \\ 46 & 54 & \\ 78 & 22 & \\ 22 & 72 & 6 \\ 47 & 53 & \\ 20 & 80 & 1 \\ 39 & 61 & \\ 42 & 57 & 1 \\ 59 & 41 & \\ 25 & 75 & \\ 48 & 52 & \\ 62 & 36 & 3 \\ 39 & 61 & \\ 45 & 51 & 4 \\ 32 & 63 & 5 \\ 38 & 57 & 5 \\ 20 & 80 & \\ 51 & 49 & \\ 39 & 55 & 6 \\ 33 & 67 & \\ 41 & 47 & 12 \\ 25 & 56 & 19 \\ 22 & 71 & 7 \\ 26 & 63 & 11 \\ 30 & 64 & 6 \\ 48 & 45 & 7 \\ 44 & 56 & \\ 7 & 80 & 12\end{array}$


Tabel B3.8 (vervolg)

Vereist opleidingsniveau voor de huidige functie volgens de werkgever

\begin{tabular}{|c|c|c|}
\hline Opleidingsrichting & $\begin{array}{r}\text { lager } \\
\%\end{array}$ & $\begin{array}{r}\text { zelfde } \\
\%\end{array}$ \\
\hline
\end{tabular}

BOL niveau $3 / 4$ (vervolg)

MKF Commercieel

MKF Secretarieel

MKF Detailhandel/ambulante handel

MKF Horeca, instellingskeuken en contractcatering

MKF Toerisme, recreatie en reizen

MKF Assistenten gezondheidszorg

MKF Sport en bewegen

MKF Verpleging en verzorging

MKF Sociaal-pedagogisch werk algemeen

MKF Sociaal-juridisch werk

$\begin{array}{rrr}22 & 71 & 7 \\ 28 & 67 & 5 \\ 67 & 32 & 1 \\ 49 & 45 & 6 \\ 30 & 66 & 4 \\ 26 & 73 & 2 \\ 32 & 62 & 6 \\ 4 & 89 & 6 \\ 20 & 75 & 4 \\ 17 & 43 & 39\end{array}$

$B B L$ niveau $1 / 2$

$A B$ Groene ruimte

$A B$ Beveiliging

AB Detailhandel/ambulante handel

$A B$ Verpleging en verzorging

BB Plantenteelt

BB Bloemschikken

BB Groene ruimte

BB Bouw

BB Houtbewerking en woninginrichting

BB Grond-, water en wegenbouw

BB Constructie-, plaatwerken/pijpenbewerken

BB Montage/onderhoud/operationele techniek

BB Motorvoertuigen

BB Energietechniek

BB Installatie-, service- en onderhoudstechniek

BB Procestechniek

BB Wegvervoer

BB Detailhandel/ambulante handel

BB Opslag/magazijn

BB Horeca, instellingskeuken en contractcatering

BB Facilitaire dienstverlening

BB Verpleging en verzorging

BB Uiterlijke verzorging

$\begin{array}{lrr}50 & 47 & 3 \\ 88 & 4 & 8 \\ 71 & 29 & \\ 29 & 53 & 18 \\ 52 & 35 & 13 \\ 49 & 37 & 15 \\ 44 & 40 & 16 \\ 33 & 45 & 22 \\ 38 & 38 & 24 \\ 70 & 20 & 10 \\ 38 & 48 & 14 \\ 53 & 27 & 20 \\ 31 & 43 & 26 \\ 28 & 48 & 24 \\ 24 & 20 & 56 \\ 68 & 14 & 19 \\ 42 & 42 & 15 \\ 69 & 22 & 9 \\ 82 & 18 & \\ 16 & 43 & 41 \\ 53 & 47 & \\ 10 & 67 & 23 \\ 45 & 20 & 35\end{array}$

$B B L$ niveau 3/4

ZB Bloemschikken

ZB Groene ruimte

ZB Bouw

ZB Grond-, water- en wegenbouw

ZB Constructie-, plaatwerken/pijpenbewerken

ZB Motorvoertuigen

ZB Energie- en informatietechniek

ZB Energietechniek

ZB Beheer, ontwerp en management (instal. techn)

ZB Installatie-, service- en onderhoudstechniek

ZB Procestechniek

ZB Automatisering

ZB Detailhandel/ambulante handel

ZB Horeca, instellingskeuken en contractcatering

$Z B$ Verpleging en verzorging

ZB Uiterlijke verzorging

MKF Bouw

MKF Detailhandel/ambulante handel

MKF Verpleging en verzorging

MKF Sociaal-pedagogisch werk

Specialist Energietechniek

Specialist Verpleging en verzorging

$\begin{array}{rr}39 & \\ 44 & \\ 45 & \\ 26 & \\ 59 & 5 \\ 44 & \\ 80 & \\ 50 & \\ 72 & \\ 50 & 6 \\ 26 & \\ 93 & 5 \\ 30 & \\ 89 & \\ 91 & \\ 46 & \\ 50 & 0 \\ 56 & \\ 92 & \\ 81 & 3 \\ 67 & 3 \\ 89 & 14 \\ & \\ & \\ & \\ & \\ & \end{array}$

Zie ook toelichting bladzijde 41 
Tabel B3.9

Vereiste opleidingsrichting voor de huidige functie volgens de werkgever

\begin{tabular}{lrrr}
\hline Opleidingsrichting & $\begin{array}{r}\text { eigen/ } \\
\text { verwante } \\
\text { richting } \\
\%\end{array}$ & $\begin{array}{r}\text { andere } \\
\text { richting }\end{array}$ & $\begin{array}{r}\text { geen } \\
\text { richting }\end{array}$ \\
$\%$ & $\%$ & $\%$ \\
\hline
\end{tabular}

VBO

IVBO Landbouw en natuurlijke omgeving $\quad 37 \quad 39$

Landbouw en natuurlijke omgeving

$\begin{array}{lll}60 & 2 & 38 \\ 77 & & 23 \\ 79 & & 21 \\ 67 & 0 & 33 \\ 67 & 5 & 29 \\ 78 & 4 & 17 \\ 69 & & 31 \\ 52 & 5 & 43 \\ 52 & 2 & 46 \\ 69 & & 31\end{array}$

Bouwtechniek

Mechanische techniek

Elektrotechniek

Motorvoertuigentechniek

Consumptieve techniek

Administratie

Verkoop

Verzorging

Uiterlijke verzorging

BOL niveau $1 / 2$

AB Beveiliging

BB Plantenteelt

BB Bloemschikken

BB Groene ruimte

BB Houtbewerking en woninginrichting

BB Detailhandel/ambulante handel

BB Horeca, instellingskeuken en contractcatering

BB Verpleging en verzorging

$\begin{array}{rrr}42 & 2 & 57 \\ 60 & 7 & 33 \\ 55 & & 45 \\ 48 & 23 & 28 \\ 74 & 7 & 20 \\ 42 & 11 & 47 \\ 79 & & 21 \\ 60 & 5 & 35\end{array}$

BOL niveau $3 / 4$

ZB Plantenteelt

ZB Veehouderij

ZB Bloemschikken

ZB Dierverzorging en veterinaire ondersteuning

ZB Paardenhouderij en paardensport

ZB Groene ruimte

ZB Graf. techn, communicatie, audiovisueel en multimedia

ZB Scheepvaart

ZB Bedrijfsadministratief

ZB Toerisme, recreatie en reizen

$Z B$ Verpleging en verzorging

ZB Uiterlijke verzorging

KF Plantenteelt

KF Veehouderij

KF Levensmiddelentechnologie

KF Bloemschikken

KF Dierverzorging en veterinaire ondersteuning

KF Paardenhouderij en paardensport

KF Groene ruimte

MKF Bouw

MKF Houtbewerking en woninginrichting

MKF Grond-, water- en wegenbouw

MKF Beschermings- en afwerkingstechnieken

MKF Reclame, presentatie en communicatie

MKF Werktuigbouwkunde

MKF Motorvoertuigen

MKF Energie- en informatietechniek

MKF Informatietechniek

MKF Graf techn, communicatie, audiovisueel en multimedia

MKF Laboratoriumtechniek

MKF Scheepvaart

MKF Transport en logistiek

$\begin{array}{lrr}65 & 2 & 33 \\ 44 & 6 & 50 \\ 53 & 2 & 45 \\ 41 & 4 & 54 \\ 21 & 29 & 50 \\ 68 & 0 & 32 \\ 87 & & 13 \\ 80 & & 20 \\ 82 & & 18 \\ 70 & 6 & 24 \\ 79 & 1 & 21 \\ 69 & 2 & 29 \\ 60 & 5 & 35 \\ 54 & 10 & 35 \\ 69 & & 31 \\ 71 & 4 & 25 \\ 43 & & 57 \\ 43 & 7 & 50 \\ 79 & 1 & 20 \\ 78 & 7 & 15 \\ 65 & 6 & 29 \\ 72 & 8 & 20 \\ 75 & 4 & 21 \\ 74 & 4 & 22 \\ 81 & 5 & 14 \\ 72 & 6 & 22 \\ 87 & 7 & 7 \\ 73 & 4 & 23 \\ 82 & 3 & 15 \\ 81 & 5 & 14 \\ 79 & & 21 \\ 61 & 2 & 37\end{array}$


Tabel B3.9 (vervolg)

Vereiste opleidingsrichting voor de huidige functie volgens de werkgever

\begin{tabular}{lrrr}
\hline Opleidingsrichting & $\begin{array}{r}\text { eigen/ } \\
\text { verwante } \\
\text { richting } \\
\%\end{array}$ & $\begin{array}{r}\text { andere } \\
\text { richting }\end{array}$ & $\begin{array}{r}\text { geen } \\
\text { richting }\end{array}$ \\
& & $\%$ \\
\hline
\end{tabular}

BOL niveau 3/4 (vervolg)

MKF Bedrijfsadministratief

MKF Commercieel

MKF Secretarieel

MKF Detailhandel/ambulante handel

MKF Horeca, instellingskeuken en contractcatering

MKF Toerisme, recreatie en reizen

MKF Assistenten gezondheidszorg

MKF Sport en bewegen

MKF Verpleging en verzorging

MKF Sociaal-pedagogisch werk algemeen

MKF Sociaal-juridisch werk

$\begin{array}{rrr}90 & 2 & 7 \\ 79 & 4 & 17 \\ 79 & 8 & 14 \\ 36 & 10 & 54 \\ 58 & 10 & 32 \\ 69 & 7 & 24 \\ 87 & 1 & 12 \\ 85 & 5 & 10 \\ 85 & 2 & 13 \\ 78 & 1 & 21 \\ 74 & & 26\end{array}$

BBL niveau $1 / 2$

$A B$ Groene ruimte

$A B$ Beveiliging

$A B$ Detailhandel/ambulante handel

$A B$ Verpleging en verzorging

BB Plantenteelt

BB Bloemschikken

BB Groene ruimte

BB Bouw

BB Houtbewerking en woninginrichting

BB Grond-, water en wegenbouw

BB Constructie-, plaatwerken/pijpenbewerken

BB Montage/onderhoud/operationele techniek

BB Motorvoertuigen

BB Energietechniek

BB Installatie-, service- en onderhoudstechniek

BB Procestechniek

BB Wegvervoer

BB Detailhandel/ambulante handel

BB Opslag/magazijn

BB Horeca, instellingskeuken en contractcatering

BB Facilitaire dienstverlening

$B B$ Verpleging en verzorging

BB Uiterlijke verzorging

$\begin{array}{lrl}76 & 3 & 21 \\ 55 & 14 & 32 \\ 35 & & 65 \\ 59 & 6 & 35 \\ 47 & 4 & 49 \\ 56 & 2 & 42 \\ 76 & 3 & 21 \\ 85 & & 15 \\ 76 & & 24 \\ 66 & & 34 \\ 62 & 5 & 33 \\ 67 & 7 & 27 \\ 70 & & 30 \\ 87 & 3 & 10 \\ 88 & & 12 \\ 68 & 14 & 19 \\ 72 & & 28 \\ 43 & 5 & 52 \\ 71 & & 29 \\ 65 & 4 & 31 \\ 87 & & 13 \\ 79 & 4 & 18 \\ 77 & & 23\end{array}$

BBL niveau $3 / 4$

ZB Bloemschikken

ZB Groene ruimte

ZB Bouw

ZB Grond-, water- en wegenbouw

ZB Constructie-, plaatwerken/pijpenbewerken

ZB Motorvoertuigen

ZB Energie- en informatietechniek

ZB Energietechniek

ZB Beheer, ontwerp en management (instal. techn)

ZB Installatie-, service- en onderhoudstechniek

ZB Procestechniek

ZB Automatisering

ZB Detailhandel/ambulante handel

ZB Horeca, instellingskeuken en contractcatering

ZB Verpleging en verzorging

ZB Uiterlijke verzorging

MKF Bouw

MKF Detailhandel/ambulante handel

$\begin{array}{rr} & 18 \\ 2 & 19 \\ 1 & 25 \\ 3 & 26 \\ & 5 \\ & 17 \\ 7 & 7 \\ 6 & \\ & 12 \\ & 10 \\ & 10 \\ & \\ 12 & 42 \\ 3 & 5 \\ 1 & 10 \\ 5 & 13 \\ & 8 \\ 5 & 41\end{array}$


Tabel B3.9 (vervolg)

Vereiste opleidingsrichting voor de huidige functie volgens de werkgever

\begin{tabular}{lrrr}
\hline Opleidingsrichting & $\begin{array}{r}\text { eigen/ } \\
\text { verwante } \\
\text { richting } \\
\%\end{array}$ & $\begin{array}{r}\text { andere } \\
\text { richting }\end{array}$ & $\begin{array}{r}\text { geen } \\
\text { richting }\end{array}$ \\
& & $\%$ & $\%$ \\
\hline
\end{tabular}

BBL niveau 3/4 (vervolg)

MKF Verpleging en verzorging

MKF Sociaal-pedagogisch werk

Specialist Energietechniek

Specialist Verpleging en verzorging

89

2

5
5
9
11

Zie ook toelichting bladzijde 42 
Tabel B3.10

Feitelijke wekelijkse arbeidsduur van werkende schoolverlaters

Opleidingsrichting

feitelijke

wekelijkse

arbeidsduur

uren

VBO

IVBO Landbouw en natuurlijke omgeving $\quad 34,1$

Landbouw en natuurlijke omgeving $\quad 33,7$

$\begin{array}{ll}\text { Bouwtechniek } & 35,2\end{array}$

Mechanische techniek $\quad 37,8$

$\begin{array}{lr}\text { Elektrotechniek } & 34,1\end{array}$

Motorvoertuigentechniek $\quad 35,4$

Consumptieve techniek $\quad 34,0$

$\begin{array}{ll}\text { Administratie } & 33,6\end{array}$

Verkoop $\quad 33,8$

Verzorging $\quad 33,1$

$\begin{array}{ll}\text { Uiterlijke verzorging } & 30,2\end{array}$

BOL niveau $1 / 2$

AB Beveiliging

$\begin{array}{lr}\text { BB Bloemschikken } & 31,7 \\ \text { BB Groeneruint } & 36,6\end{array}$

BB Groene ruimte $\quad 36,6$

$\begin{array}{ll}\text { BB Houtbewerking en woninginrichting } & 38,0\end{array}$

BB Detailhandel/ambulante handel $\quad 33,7$

BB Horeca, instellingskeuken en contractcatering $\quad 34,4$

$B B$
$B B$

BOL niveau $3 / 4$

ZB Plantenteelt

$\begin{array}{ll}\text { ZB Bloemschikken } & 34,7 \\ & \end{array}$

ZB Dierverzorging en veterinaire ondersteuning $\quad 34,7$

ZB Paardenhouderij en paardensport $\quad 31,7$

ZB Groene ruimte $\quad 37,0$

ZB Graf. techn, communicatie, audiovisueel en multimedia

ZB Scheepvaart $\quad 45,8$

ZB Bedrijfsadministratief $\quad 36,8$

ZB Toerisme, recreatie en reizen $\quad 36,8$

ZB Verpleging en verzorging $\quad 32,4$

ZB Uiterlijke verzorging $\quad 31,6$

$\begin{array}{lr}\text { KF Plantenteelt } & 38,0\end{array}$

KF Veehouderij $\quad 37,2$

KF Levensmiddelentechnologie $\quad 36,9$

KF Bloemschikken $\quad 34,8$

KF Dierverzorging en veterinaire ondersteuning $\quad 33,6$

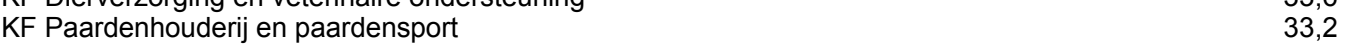

KF Groene ruimte $\quad 36,9$

MKF Bouw $\quad 38,9$

MKF Houtbewerking en woninginrichting $\quad 38,3$

MKF Grond-, water- en wegenbouw $\quad 40,0$

MKF Beschermings- en afwerkingstechnieken $\quad 36,3$

MKF Reclame, presentatie en communicatie $\quad 36,2$

$\begin{array}{lr}\text { MKF Werktuigbouwkunde } & 39,1\end{array}$

MKF Motorvoertuigen $\quad 36,9$

MKF Energie- en informatietechniek $\quad 38,3$

MKF Informatietechniek $\quad 38,4$

MKF Graf. techn, communicatie, audiovisueel en multimedia $\quad 38,0$

MKF Laboratoriumtechniek $\quad 36,5$

MKF Scheepvaart $\quad 46,4$

MKF Transport en logistiek $\quad 38,9$ 
Tabel B3.10 (vervolg)

Feitelijke wekelijkse arbeidsduur van werkende schoolverlaters

Opleidingsrichting

feitelijke

wekelijkse

arbeidsduur

uren

BOL niveau $3 / 4$ (vervolg)

MKF Bedrijfsadministratief

MKF Commercieel

37,6

MKF Secretarieel

38,0

MKF Detailhandel/ambulante handel $\quad 35,0$

MKF Horeca, instellingskeuken en contractcatering $\quad 36,8$

$\begin{array}{ll}\text { MKF Toerisme, recreatie en reizen } & 37,2\end{array}$

MKF Assistenten gezondheidszorg $\quad 34,9$

MKF Sport en bewegen $\quad 34,4$

MKF Verpleging en verzorging $\quad 34,5$

MKF Sociaal-pedagogisch werk algemeen $\quad 28,3$

MKF Sociaal-juridisch werk $\quad 34,0$

BBL niveau $1 / 2$

AB Groene ruimte $\quad 35,6$

$A B$ Beveiliging $\quad 35,3$

AB Detailhandel/ambulante handel $\quad 33,6$

AB Verpleging en verzorging $\quad 27,7$

$\begin{array}{ll}\text { BB Plantenteelt } & 37,4\end{array}$

BB Bloemschikken $\quad 33,7$

BB Groene ruimte $\quad 37,3$

BB Bouw $\quad 38,3$

BB Houtbewerking en woninginrichting $\quad 38,0$

BB Grond-, water en wegenbouw $\quad 36,8$

BB Constructie-, plaatwerken/pijpenbewerken $\quad 39,3$

BB Montage/onderhoud/operationele techniek $\quad 37,7$

$\begin{array}{ll}\text { BB Motorvoertuigen } & 37,9\end{array}$

BB Energietechniek $\quad 38,7$

$\begin{array}{ll}\text { BB Installatie-, service- en onderhoudstechniek } & 39,2\end{array}$

BB Procestechniek $\quad 36,1$

BB Wegvervoer $\quad 41,2$

$\begin{array}{ll}\text { BB Detailhandel/ambulante handel } & 34,7\end{array}$

BB Opslag/magazijn $\quad 36,5$

BB Horeca, instellingskeuken en contractcatering $\quad 34,6$

BB Facilitaire dienstverlening $\quad 22,5$

BB Verpleging en verzorging $\quad 26,1$

$\begin{array}{ll}\text { BB Uiterlijke verzorging } & 34,0\end{array}$

BBL niveau $3 / 4$

ZB Bloemschikken $\quad 35,6$

ZB Groene ruimte $\quad 37,4$

\begin{tabular}{ll} 
ZB Bouw & 39,4 \\
\hline
\end{tabular}

ZB Grond-, water- en wegenbouw $\quad 39,4$

ZB Constructie-, plaatwerken/pijpenbewerken $\quad 39,2$

ZB Motorvoertuigen $\quad 38,3$

ZB Energie- en informatietechniek $\quad 38,7$

\begin{tabular}{ll} 
ZB Energietechniek & 39,2 \\
\hline
\end{tabular}

ZB Beheer, ontwerp en management (instal. techn) $\quad 38,7$

ZB Installatie-, service- en onderhoudstechniek $\quad 38,6$

$\begin{array}{ll}\text { ZB Procestechniek } & 36,0\end{array}$

ZB Automatisering $\quad 38,0$

ZB Detailhandel/ambulante handel $\quad 35,6$

ZB Horeca, instellingskeuken en contractcatering $\quad 38,3$

ZB Verpleging en verzorging $\quad 29,9$

ZB Uiterlijke verzorging $\quad 34,3$

MKF Bouw $\quad 39,5$

$\begin{array}{ll}\text { MKF Detailhandel/ambulante handel } & 34,6\end{array}$ 
Tabel B3.10 (vervolg)

Feitelijke wekelijkse arbeidsduur van werkende schoolverlaters

Opleidingsrichting

feitelijke

wekelijkse

arbeidsduur

uren

BBL niveau 3/4 (vervolg)

MKF Verpleging en verzorging

34,1

MKF Sociaal-pedagogisch werk

28,2

Specialist Energietechniek

39,4

Specialist Verpleging en verzorging

26,8

Zie ook toelichting bladzijde 44 
Tabel B3.11

Oordeel van de werkende schoolverlaters over de aansluiting tussen de afgesloten opleiding en de huidige functie

\begin{tabular}{lrrrr}
\hline Opleidingsrichting & goed & $\begin{array}{r}\text { vol- } \\
\text { doende }\end{array}$ & matig & slecht \\
& $\%$ & $\%$ & $\%$ & $\%$ \\
\hline
\end{tabular}

\section{VBO}

IVBO Landbouw en natuurlijke omgeving

Landbouw en natuurlijke omgeving

Bouwtechniek

Mechanische techniek

Elektrotechniek

Motorvoertuigentechniek

Consumptieve techniek

Administratie

Verkoop

Verzorging

Uiterlijke verzorging

$\begin{array}{rrrr}51 & 27 & 13 & 8 \\ 40 & 30 & 15 & 14 \\ 70 & 20 & 6 & 4 \\ 60 & 20 & 10 & 10 \\ 52 & 31 & 7 & 10 \\ 64 & 36 & & \\ 61 & 30 & 4 & 4 \\ 36 & 21 & 21 & 21 \\ 73 & 18 & & 9 \\ 70 & 25 & 2 & 3 \\ 65 & 23 & 8 & 5\end{array}$

BOL niveau $1 / 2$

$\mathrm{AB}$ Beveiliging

BB Plantenteelt

BB Bloemschikken

BB Groene ruimte

BB Houtbewerking en woninginrichting

BB Detailhandel/ambulante handel

BB Horeca, instellingskeuken en contractcatering

$B B$ Verpleging en verzorging

$\begin{array}{rrrr}40 & 33 & 13 & 15 \\ 48 & 46 & 6 & \\ 64 & 23 & 11 & 2 \\ 71 & 29 & & \\ 48 & 17 & 17 & 17 \\ 45 & 40 & 5 & 10 \\ 59 & 28 & 3 & 11 \\ 58 & 22 & 14 & 6\end{array}$

BOL niveau $3 / 4$

ZB Plantenteelt

ZB Veehouderi

ZB Bloemschikken

ZB Dierverzorging en veterinaire ondersteuning

ZB Paardenhouderij en paardensport

ZB Groene ruimte

ZB Graf. techn, communicatie, audiovisueel en multimedia

ZB Scheepvaart

ZB Bedrijfsadministratief

ZB Toerisme, recreatie en reizen

$Z B$ Verpleging en verzorging

ZB Uiterlijke verzorging

KF Plantenteelt

KF Veehouderi]

KF Levensmiddelentechnologie

KF Bloemschikken

KF Dierverzorging en veterinaire ondersteuning

KF Paardenhouderij en paardensport

KF Groene ruimte

MKF Bouw

MKF Houtbewerking en woninginrichting

MKF Grond-, water- en wegenbouw

MKF Beschermings- en afwerkingstechnieken

MKF Reclame, presentatie en communicatie

MKF Werktuigbouwkunde

MKF Motorvoertuigen

MKF Energie- en informatietechniek

MKF Informatietechniek

MKF Graf. techn, communicatie, audiovisueel en multimedia

MKF Laboratoriumtechniek

MKF Scheepvaart

MKF Transport en logistiek 
Tabel B3.11

Oordeel van de werkende schoolverlaters over de aansluiting tussen de afgesloten opleiding en de huidige functie

\begin{tabular}{|c|c|c|c|}
\hline Opleidingsrichting & $\begin{array}{r}\text { goed } \\
\%\end{array}$ & $\begin{array}{r}\text { vol- } \\
\text { doende } \\
\%\end{array}$ & $\begin{array}{r}\text { matig } \\
\%\end{array}$ \\
\hline
\end{tabular}

BOL niveau 3/4 (vervolg)

MKF Bedrijfsadministratief

MKF Commercieel

MKF Secretarieel

MKF Detailhandel/ambulante handel

MKF Horeca, instellingskeuken en contractcatering

MKF Toerisme, recreatie en reizen

MKF Assistenten gezondheidszorg

MKF Sport en bewegen

MKF Verpleging en verzorging

MKF Sociaal-pedagogisch werk algemeen

MKF Sociaal-juridisch werk

$\begin{array}{rrrr}59 & 37 & 2 & 2 \\ 39 & 43 & 11 & 7 \\ 31 & 51 & 15 & 4 \\ 33 & 41 & 22 & 3 \\ 48 & 45 & 3 & 4 \\ 48 & 32 & 18 & 2 \\ 57 & 34 & 7 & 2 \\ 49 & 44 & 7 & \\ 32 & 32 & 29 & 7 \\ 49 & 33 & 11 & 7 \\ 30 & 48 & 9 & 13\end{array}$

BBL niveau $1 / 2$

$A B$ Groene ruimte

$A B$ Beveiliging

$A B$ Detailhandel/ambulante handel

$A B$ Verpleging en verzorging

BB Plantenteelt

BB Bloemschikken

BB Groene ruimte

BB Bouw

BB Houtbewerking en woninginrichting

BB Grond-, water en wegenbouw

BB Constructie-, plaatwerken/pijpenbewerken

BB Montage/onderhoud/operationele techniek

BB Motorvoertuigen

BB Energietechniek

BB Installatie-, service- en onderhoudstechniek

BB Procestechniek

BB Wegvervoer

BB Detailhandel/ambulante handel

BB Opslag/magazijn

BB Horeca, instellingskeuken en contractcatering

BB Facilitaire dienstverlening

$B B$ Verpleging en verzorging

BB Uiterlijke verzorging

$\begin{array}{rrrr}53 & 33 & 15 & \\ 61 & 22 & 9 & 9 \\ 64 & 26 & 6 & 5 \\ 61 & 22 & 11 & 6 \\ 54 & 29 & 7 & 10 \\ 57 & 29 & 6 & 7 \\ 56 & 34 & 6 & 3 \\ 68 & 27 & 1 & 3 \\ 69 & 26 & & 6 \\ 50 & 33 & 8 & 8 \\ 57 & 25 & 12 & 6 \\ 29 & 50 & 21 & \\ 46 & 38 & 11 & 5 \\ 52 & 23 & 19 & 6 \\ 68 & 29 & 3 & \\ 51 & 38 & & 11 \\ 72 & 24 & 4 & \\ 51 & 28 & 13 & 8 \\ 46 & 45 & 4 & 4 \\ 84 & 11 & 1 & 4 \\ 50 & 44 & 6 & \\ 68 & 29 & 1 & 2 \\ 66 & 21 & 3 & 10\end{array}$

BBL niveau $3 / 4$

ZB Bloemschikken

ZB Groene ruimte

ZB Bouw

ZB Grond-, water- en wegenbouw

ZB Constructie-, plaatwerken/pijpenbewerken

ZB Motorvoertuigen

ZB Energie- en informatietechniek

ZB Energietechniek

ZB Beheer, ontwerp en management (instal. techn)

ZB Installatie-, service- en onderhoudstechniek

ZB Procestechniek

ZB Automatisering

ZB Detailhandel/ambulante handel

ZB Horeca, instellingskeuken en contractcatering

ZB Verpleging en verzorging

ZB Uiterlijke verzorging

MKF Bouw

MKF Detailhandel/ambulante handel

$\begin{array}{rrrr}53 & 35 & 6 & 6 \\ 51 & 36 & 12 & 1 \\ 63 & 30 & 6 & 1 \\ 66 & 28 & 6 & \\ 68 & 23 & & 9 \\ 53 & 26 & 21 & \\ 33 & 47 & & 20 \\ 29 & 62 & 9 & \\ 56 & 33 & 11 & \\ 51 & 30 & 15 & 4 \\ 58 & 37 & 5 & \\ 29 & 36 & 21 & 14 \\ 40 & 38 & 16 & 6 \\ 54 & 39 & 5 & 2 \\ 65 & 30 & 4 & 1 \\ 64 & 24 & 7 & 5 \\ 60 & 27 & 7 & 7 \\ 68 & 26 & & 6\end{array}$


Tabel B3.11 (vervolg)

Oordeel van de werkende schoolverlaters over de aansluiting tussen de afgesloten opleiding en de huidige functie

\begin{tabular}{lrrrr} 
Opleidingsrichting & goed & $\begin{array}{r}\text { vol- } \\
\text { doende }\end{array}$ & matig & slecht \\
& $\%$ & $\%$ & $\%$ & $\%$ \\
\hline
\end{tabular}

BBL niveau 3/4 (vervolg)

MKF Verpleging en verzorging

$\begin{array}{llll}35 & 40 & 22 & 3\end{array}$

MKF Sociaal-pedagogisch werk

Specialist Energietechniek

56

Specialist Verpleging en verzorging

$36 \quad 59$

Zie ook toelichting bladzijde 45 
Tabel B3.12

Percentage werkende schoolverlaters dat op zoek is naar een andere baan

Opleidingsrichting

VBO

IVBO Landbouw en natuurlijke omgeving

Landbouw en natuurlijke omgeving

Bouwtechniek

Mechanische techniek

Elektrotechniek

Motorvoertuigentechniek

Consumptieve techniek

Verkoop

Verzorging

Uiterlijke verzorging

BOL niveau $1 / 2$

$A B$ Beveiliging

BB Plantenteelt

BB Bloemschikken

BB Groene ruimte

BB Houtbewerking en woninginrichting

BB Detailhandel/ambulante handel

BB Horeca, instellingskeuken en contractcatering

BB Verpleging en verzorging

BOL niveau $3 / 4$

ZB Plantenteelt

ZB Veehouderi

ZB Bloemschikken

ZB Dierverzorging en veterinaire ondersteuning

ZB Paardenhouderij en paardensport

ZB Groene ruimte

ZB Graf. techn, communicatie, audiovisueel en multimedia

ZB Scheepvaart

ZB Bedrijfsadministratief

ZB Toerisme, recreatie en reizen

$Z B$ Verpleging en verzorging

ZB Uiterlijke verzorging

KF Plantenteelt

KF Veehouderij

KF Levensmiddelentechnologie

KF Bloemschikken

KF Dierverzorging en veterinaire ondersteuning

KF Paardenhouderij en paardensport

KF Groene ruimte

MKF Bouw

MKF Houtbewerking en woninginrichting

MKF Grond-, water- en wegenbouw

MKF Beschermings- en afwerkingstechnieken

MKF Reclame, presentatie en communicatie

MKF Werktuigbouwkunde

MKF Motorvoertuigen

MKF Energie- en informatietechniek

MKF Informatietechniek

MKF Graf. techn, communicatie, audiovisueel en multimedia

MKF Laboratoriumtechniek

MKF Scheepvaart

MKF Transport en logistiek

MKF Bedrijfsadministratief

MKF Commercieel

MKF Secretarieel

MKF Detailhandel/ambulante handel 
Tabel B3.12 (vervolg)

Percentage werkende schoolverlaters dat op zoek is naar een andere baan

Opleidingsrichting

BOL niveau 3/4 (vervolg)

MKF Horeca, instellingskeuken en contractcatering

MKF Toerisme, recreatie en reizen

MKF Assistenten gezondheidszorg

MKF Sport en bewegen

MKF Verpleging en verzorging

MKF Sociaal-pedagogisch werk algemeen

MKF Sociaal-juridisch werk

$B B L$ niveau $1 / 2$

AB Groene ruimte

$A B$ Beveiliging

$A B$ Detailhandel/ambulante handel

$A B$ Verpleging en verzorging

BB Plantenteelt

BB Bloemschikken

BB Groene ruimte

BB Bouw

BB Houtbewerking en woninginrichting

BB Constructie-, plaatwerken/pijpenbewerken

BB Montage/onderhoud/operationele techniek

BB Motorvoertuigen

BB Energietechniek

BB Installatie-, service- en onderhoudstechniek

BB Wegvervoer

BB Detailhandel/ambulante handel

BB Opslag/magazijn

BB Horeca, instellingskeuken en contractcatering

BB Facilitaire dienstverlening

BB Verpleging en verzorging

BB Uiterlijke verzorging

BBL niveau 3/4

ZB Bloemschikken

ZB Groene ruimte

ZB Bouw

ZB Grond-, water- en wegenbouw

ZB Constructie-, plaatwerken/pijpenbewerken

ZB Motorvoertuigen

ZB Energie- en informatietechniek

ZB Installatie-, service- en onderhoudstechniek

ZB Procestechniek

ZB Automatisering

ZB Detailhandel/ambulante handel

ZB Horeca, instellingskeuken en contractcatering

ZB Verpleging en verzorging

ZB Uiterlijke verzorging

MKF Bouw

MKF Detailhandel/ambulante handel

MKF Verpleging en verzorging

MKF Sociaal-pedagogisch werk

Specialist Energietechniek

Specialist Verpleging en verzorging 
Tabel B4.1

Enkele kernindicatoren

\begin{tabular}{|c|c|c|c|c|c|c|c|c|c|}
\hline \multirow[t]{2}{*}{ Opleidingsrichting } & $\begin{array}{r}\text { opgehoogd } \\
\text { aantal } \\
\text { populatie }\end{array}$ & $\begin{array}{c}\text { verder } \\
\text { leren }\end{array}$ & $\begin{array}{r}\text { zelfde } \\
\text { opleiding } \\
\text { opnieuw? }\end{array}$ & $\begin{array}{l}\text { werk- } \\
\text { loos- } \\
\text { heid }\end{array}$ & $\begin{array}{r}\text { intrede } \\
\text { werkloos- } \\
\text { heid }\end{array}$ & $\begin{array}{r}\text { flexibele } \\
\text { aan- } \\
\text { stelling }\end{array}$ & $\begin{array}{r}\text { bruto } \\
\text { uurloon }\end{array}$ & $\begin{array}{r}\text { minimaal } \\
\text { eigen } \\
\text { niveau }\end{array}$ & $\begin{array}{r}\text { eigen/ } \\
\text { verwante } \\
\text { richting }\end{array}$ \\
\hline & & $\%$ & $\%$ & $\%$ & maanden & $\%$ & $€$ & $\%$ & $\%$ \\
\hline
\end{tabular}

IVBO Landbouw en natuurlijke omgeving

IVBO Bouwtechniek

IVBO Verzorging

Landbouw en natuurlijke omgeving

Bouwtechniek

1.693

307

3.713

4.053

.469

Mechanische techniek

Motorvoertuigentechniek

Consumptieve techniek

Nautische opleidingen

Administratie

Verkoop

Verzorging

Uiterlijke verzorging

68
-
83
81
86
80
80
80
76
84
86
83
82
77

BOL niveau $1 / 2$

$A B$ Motorvoertuigen

$A B$ Beveiliging

$A B$ Secretarieel

$A B$ Verpleging en verzorging

BB Plantenteelt

BB Bloemschikken

BB Dierverzorging en veterinaire ondersteuning

BB Groene ruimte

BB Houtbewerking en woninginrichting

68
83
81
86
80
80
80
76
84
86
83
82
77

1.131

$\begin{array}{lr}\mathrm{x} & \\ \mathrm{x} & \\ \mathrm{x} & 10 \\ \mathrm{x} & \\ \mathrm{x} & \\ \mathrm{x} & \\ \mathrm{x} & \\ \mathrm{x} & \\ \mathrm{x} & \\ \mathrm{x} & \\ \mathrm{x} & \\ \mathrm{x} & \\ \mathrm{x} & \\ \mathrm{x} & \end{array}$

$\begin{array}{rl}7 & 0,4 \\ 8 & 0,6 \\ 10 & 1,7 \\ 2 & 0,3 \\ 3 & 0,0 \\ 0 & 0,1 \\ 2 & 0,2 \\ 0 & 0,4 \\ 4 & 0,1 \\ 0 & 0,2 \\ 7 & 0,0 \\ 4 & 0,4 \\ 2 & 0,5 \\ 4 & 0,5\end{array}$

0,4
0,6
1,7
0,3
0,0
0,1
0,2
0,4
0,1
0,2
0,0
0,4
0,5
0,5

32

$\begin{array}{rrr}4,57 & 73 & 57 \\ - & - & - \\ - & - & - \\ 4,57 & 85 & 60 \\ 4,55 & 88 & 77 \\ 4,52 & 80 & 79 \\ 4,09 & 81 & 67 \\ 4,11 & 95 & 67 \\ 4,63 & 95 & 78 \\ - & - & - \\ 4,88 & 87 & 69 \\ 3,79 & 84 & 52 \\ 4,50 & 87 & 52 \\ 4,14 & 95 & 69\end{array}$

31

25

12

30

46

$-$

23
14

16

0,5

$\begin{array}{rrrrr}141 & 18 & 76 & 10 & 0,0 \\ 703 & - & 68 & 5 & 0,2 \\ 780 & - & 80 & 57 & 0,0 \\ 66 & - & 74 & 24 & 1,2 \\ 84 & - & 56 & 3 & 1,0 \\ 84 & - & 58 & 2 & 0,3 \\ 86 & - & 67 & 30 & 1,4 \\ 99 & - & 79 & 5 & 0,3 \\ 175 & - & 68 & 3 & 0,1\end{array}$

39
19
23
21
2

$\begin{array}{rrr} & & \\ 7,29 & 18 & 42 \\ - & - & - \\ - & - & - \\ 6,34 & 38 & 60 \\ 5,05 & 37 & 55 \\ - & - & - \\ 6,25 & 55 & 48 \\ 6,89 & 80 & 74\end{array}$


Tabel B4.1 (vervolg)

Enkele kernindicatoren

\begin{tabular}{|c|c|c|c|c|c|c|c|c|c|}
\hline \multirow[t]{2}{*}{ Opleidingsrichting } & $\begin{array}{r}\text { opgehoogd } \\
\text { aantal } \\
\text { populatie }\end{array}$ & $\begin{array}{c}\text { verder } \\
\text { leren }\end{array}$ & $\begin{array}{r}\text { zelfde } \\
\text { opleiding } \\
\text { opnieuw? }\end{array}$ & $\begin{array}{c}\text { werk- } \\
\text { loos- } \\
\text { heid }\end{array}$ & $\begin{array}{r}\text { intrede } \\
\text { werkloos- } \\
\text { heid }\end{array}$ & $\begin{array}{r}\text { flexibele } \\
\text { aan- } \\
\text { stelling }\end{array}$ & $\begin{array}{r}\text { bruto } \\
\text { uurloon }\end{array}$ & $\begin{array}{r}\text { minimaal } \\
\text { eigen } \\
\text { niveau }\end{array}$ & $\begin{array}{r}\text { eigen/ } \\
\text { verwante } \\
\text { richting }\end{array}$ \\
\hline & & $\%$ & $\%$ & $\%$ & maanden & $\%$ & $€$ & $\%$ & $\%$ \\
\hline
\end{tabular}

BOL niveau 1/2 (vervolg)

BB Reclame, presentatie en communicatie

BB Motorvoertuigen

BB Graf. techn, communicatie, audiovisueel en multimedia

BB Bedrijfsadministratie

BB Secretarieel

BB Detailhandel/ambulante handel

BB Horeca, instellingskeuken en contractcatering

BB Facilitaire dienstverlening

BB Verpleging en verzorging

\section{BOL niveau $3 / 4$}

ZB Plantenteelt

ZB Veehouderij

ZB Levensmiddelentechnologie

ZB Bloemschikken

ZB Dierverzorging en veterinaire ondersteuning

ZB Paardenhouderij en paardensport

ZB Groene ruimte

ZB Werktuigbouwkund

ZB Graf. techn, communicatie, audiovisueel en multimedia

ZB Scheepvaart

ZB Bedrijfsadministratief

ZB Detailhandel/ambulante handel

ZB Groothandel/distributie

ZB Toerisme, recreatie en reizen

ZB Verpleging en verzorging

ZB Uiterlijke verzorging

KF Plantenteelt

$\begin{array}{rrrrr}83 & - & 72 & 21 & 0 \\ 192 & - & 81 & 0 & 0 \\ 44 & - & 73 & 12 & 0,4 \\ 1.007 & - & 81 & 0 & 0,5 \\ 887 & - & 57 & 0 & 1,9 \\ 1.810 & 34 & 56 & 8 & 0 \\ 1.217 & 61 & 72 & 7 & 0 \\ 609 & - & 50 & 0 & 0 \\ 2.895 & 57 & 58 & 4 & 0,0\end{array}$

0,9
0,0
0,4
0,5
1,9
0,3
0,3
0,0

$\begin{array}{rrr}263 & 28 & 65 \\ 342 & 26 & 75 \\ 73 & - & 76 \\ 316 & 30 & 64 \\ 204 & 27 & 58 \\ 64 & - & 36 \\ 375 & 31 & 61 \\ 32 & - & 94 \\ 83 & - & 78 \\ 60 & - & 77 \\ 984 & - & 73 \\ 278 & - & 76 \\ 247 & 68 & 86 \\ 710 & - & 68 \\ 2.788 & 33 & 71 \\ 1.238 & - & 77 \\ 305 & 52 & 73\end{array}$

$\begin{array}{lr}65 & 2 \\ 75 & \\ 76 & \\ 64 & \\ 58 & 2 \\ 36 & 12 \\ 61 & \\ 94 & \\ 78 & \\ 77 & \\ 73 & \\ 76 & \\ 86 & \\ 68 & \\ 71 & \\ 77 & \\ 73 & \end{array}$

0,1
0,1
0,3
0,3
1,4
1,9
0,2
0,0
0,3
0,2
0,4
0,0
0,0
0,7
0,2
0,5
0,0


Tabel B4.1 (vervolg)

Enkele kernindicatoren

\begin{tabular}{|c|c|c|c|c|c|c|c|c|c|}
\hline \multirow[t]{2}{*}{ Opleidingsrichting } & $\begin{array}{r}\text { opgehoogd } \\
\text { aantal } \\
\text { populatie }\end{array}$ & $\begin{array}{r}\text { verder } \\
\text { leren }\end{array}$ & $\begin{array}{r}\text { zelfde } \\
\text { opleiding } \\
\text { opnieuw? }\end{array}$ & $\begin{array}{c}\text { werk- } \\
\text { loos- } \\
\text { heid }\end{array}$ & $\begin{array}{r}\text { intrede } \\
\text { werkloos- } \\
\text { heid }\end{array}$ & $\begin{array}{r}\text { flexibele } \\
\text { aan- } \\
\text { stelling }\end{array}$ & $\begin{array}{r}\text { bruto } \\
\text { uurloon }\end{array}$ & $\begin{array}{r}\text { minimaal } \\
\text { eigen } \\
\text { niveau }\end{array}$ & $\begin{array}{r}\text { eigen/ } \\
\text { verwante } \\
\text { richting }\end{array}$ \\
\hline & & $\%$ & $\%$ & $\%$ & maanden & $\%$ & $€$ & $\%$ & $\%$ \\
\hline
\end{tabular}

BOL niveau 3/4 (vervolg)

KF Veehouderi]

$\begin{array}{rrrrrrrrr}606 & 46 & 73 & 4 & 0,1 & 19 & 8,00 & 41 & 54 \\ 194 & 48 & 64 & 3 & 0,2 & 32 & 8,72 & 75 & 69 \\ 190 & - & 70 & 4 & 0,2 & 25 & 6,71 & 52 & 71 \\ 226 & 37 & 80 & 0 & 0,7 & 34 & 6,20 & 39 & 43 \\ 112 & - & 58 & 0 & 0,1 & 16 & 7,83 & 61 & 43 \\ 556 & 51 & 71 & 4 & 0,4 & 24 & 8,68 & 55 & 79 \\ 112 & 68 & 65 & 0 & 0,8 & - & - & - & - \\ 1.878 & 59 & 86 & 3 & 0,4 & 18 & 9,82 & 68 & 78 \\ 356 & 22 & 79 & 5 & 0,3 & 21 & 8,78 & 62 & 65 \\ 496 & 45 & 94 & 7 & 0,3 & 20 & 8,82 & 80 & 72 \\ 233 & 32 & 68 & 6 & 0,6 & 20 & 8,95 & 49 & 75 \\ 494 & 44 & 85 & 6 & 0,7 & 34 & 7,78 & 61 & 74 \\ 40 & - & 88 & 0 & 0,3 & - & - & - & 81 \\ 1.401 & 63 & 85 & 8 & 1,2 & 18 & 8,67 & 67 & 72 \\ 541 & 57 & 80 & 0 & 0,1 & 11 & 7,72 & 59 & 87 \\ 1.114 & 69 & 83 & 6 & 0,2 & 33 & 8,08 & 75 & - \\ 406 & - & 79 & 0 & 0,0 & - & - & - & 73 \\ 1.588 & 68 & 88 & 6 & 0,5 & 20 & 8,86 & 78 & 82 \\ 360 & - & 75 & 11 & 0,3 & 23 & 8,54 & 74 & 81 \\ 898 & 53 & 77 & 5 & 0,4 & 25 & 9,87 & 70 & - \\ 94 & - & 62 & 0 & 0,3 & - & - & - & 79 \\ 217 & - & 82 & 0 & 0,3 & 17 & 9,42 & 52 & 61 \\ 346 & 37 & 88 & 2 & 0,0 & 20 & 8,91 & 56 & - \\ 499 & - & 66 & 9 & 0,7 & - & - & - & 90 \\ 2.146 & 62 & 82 & 5 & 0,5 & 31 & 7,59 & 92 & 79 \\ 3.375 & 50 & 71 & 6 & 1,0 & 40 & 8,00 & 78 & - \\ 529 & 59 & 61 & 10 & 0,0 & - & - & - & 79 \\ 1.725 & 35 & 67 & 0 & 0,4 & 33 & 7,96 & 72 & \end{array}$

KF Bloemschikken

KF Dierverzorging en veterinaire ondersteuning

KF Paardenhouderij en paardensport

KF Groene ruimte

KF Milieutoezicht

MKF Bouw

MKF Houtbewerking en woninginrichting

MKF Grond-, water- en wegenbouw

MKF Beschermings- en afwerkingstechnieken

MKF Reclame, presentatie en communicatie

MKF Operationele techniek

MKF Werktuigbouwkunde

MKF Motorvoertuigen

MKF Energie- en informatietechniek

MKF Energietechniek

ormatietechniek

MKF Laboratoriumtechniek

MKF Procestechniek

MKF Scheepvaart

MKF Transport en logistiek

MKF Automatisering

MKF Bedrijfsadministratie

MKF Commercieel

MKF Economisch-juridisch

MKF Secretarieel 
Tabel B4.1 (vervolg)

Enkele kernindicatoren

\begin{tabular}{|c|c|c|c|c|c|c|c|c|c|}
\hline \multirow[t]{2}{*}{ Opleidingsrichting } & \multirow[t]{2}{*}{$\begin{array}{r}\text { opgehoogd } \\
\text { aantal } \\
\text { populatie }\end{array}$} & \multirow[t]{2}{*}{$\begin{array}{c}\text { verder } \\
\text { leren }\end{array}$} & \multirow{2}{*}{$\begin{array}{r}\text { zelfde } \\
\text { opleiding } \\
\text { opnieuw? } \\
\%\end{array}$} & \multirow{2}{*}{$\begin{array}{c}\begin{array}{c}\text { werk- } \\
\text { loos- } \\
\text { heid } \\
\%\end{array} \\
\%\end{array}$} & \multirow{2}{*}{$\begin{array}{r}\text { intrede } \\
\text { werkloos- } \\
\text { heid } \\
\text { maanden }\end{array}$} & \multirow{2}{*}{$\begin{array}{r}\text { flexibele } \\
\text { aan- } \\
\text { stelling } \\
\%\end{array}$} & \multirow{2}{*}{$\begin{array}{r}\text { bruto } \\
\text { uurloon } \\
€\end{array}$} & \multirow{2}{*}{$\begin{array}{r}\text { minimaal } \\
\text { eigen } \\
\text { niveau } \\
\%\end{array}$} & \multirow{2}{*}{$\begin{array}{r}\text { eigen/ } \\
\text { verwante } \\
\text { richting } \\
\%\end{array}$} \\
\hline & & & & & & & & & \\
\hline \multicolumn{10}{|l|}{ BOL niveau 3/4 (vervolg) } \\
\hline MKF Detailhandel/ambulante handel & 3.071 & 57 & 67 & 4 & 0,1 & 20 & 6,86 & 33 & 36 \\
\hline MKF Groothandel/distributie & 795 & 76 & 63 & 0 & 0,2 & - & - & - & . \\
\hline MKF Horeca, instellingskeuken en contractcatering & 1.150 & 36 & 84 & 1 & 0,2 & 20 & 9,08 & 51 & 58 \\
\hline MKF Toerisme, recreatie en reizen & 1.151 & 34 & 74 & 8 & 0,6 & 23 & 8,06 & 70 & 69 \\
\hline MKF Assistenten gezondheidszorg & 1.552 & 23 & 78 & 1 & 0,0 & 10 & 7,75 & 75 & 87 \\
\hline MKF Facilitaire dienstverlening & 64 & - & 72 & 0 & 0,7 & - & - & - & - \\
\hline MKF Sport en bewegen & 618 & 47 & 94 & 0 & 0,3 & 20 & 10,11 & 68 & 85 \\
\hline MKF Verpleging en verzorging & 1.376 & 27 & 66 & 0 & 0,0 & 4 & 9,75 & 95 & 85 \\
\hline MKF Maatschappelijke dienstverlening & 306 & 69 & 82 & 0 & 0,2 & - & - & - & - \\
\hline MKF Sociaal-pedagogisch werk algemeen & 9.045 & 52 & 85 & 6 & 0,4 & 20 & 8,54 & 79 & 78 \\
\hline MKF Sociaal-juridisch werk & 937 & 72 & 85 & 4 & 0,5 & 26 & 11,00 & 82 & 74 \\
\hline \multicolumn{10}{|l|}{ BBL niveau $1 / 2$} \\
\hline AB Groene ruimte & 334 & - & 61 & 0 & 0,1 & - & 7,44 & 50 & 76 \\
\hline AB Beveiliging & 1.088 & - & 68 & 4 & 1,0 & 4 & 10,14 & 12 & 55 \\
\hline AB Detailhandel/ambulante handel & 320 & - & 48 & 15 & 0,2 & 15 & 5,08 & 29 & 35 \\
\hline$A B$ Verpleging en verzorging & 98 & - & 90 & 5 & 0,7 & 11 & 9,32 & 71 & 59 \\
\hline BB Plantenteelt & 213 & - & 72 & 5 & 0,0 & - & 7,52 & 48 & 47 \\
\hline BB Bloemschikken & 326 & 36 & 61 & 3 & 0,3 & 4 & 5,28 & 52 & 56 \\
\hline BB Groene ruimte & 602 & 28 & 79 & 0 & 0,3 & 1 & 8,48 & 56 & 76 \\
\hline BB Bouw & 2.597 & 42 & 77 & 3 & 0,3 & 12 & 8,61 & 67 & 85 \\
\hline BB Houtbewerking en woninginrichting & 754 & 49 & 82 & 5 & 0,3 & 14 & 6,58 & 62 & 76 \\
\hline BB Grond-, water en wegenbouw & 609 & - & 79 & 8 & 0,1 & 11 & 8,22 & 30 & 66 \\
\hline BB Beschermings- en afwerkingstechnieken & 480 & - & 81 & 0 & 1,5 & - & - & - & 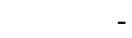 \\
\hline BB Constructie-, plaatwerken/pijpenbewerken & 690 & - & 71 & 2 & 0,0 & 22 & 7,51 & 62 & 62 \\
\hline BB Montage/onderhoud/operationele techniek & 117 & - & 50 & 0 & 0,2 & 20 & 8,23 & 47 & 67 \\
\hline BB Motorvoertuigen & 1.423 & - & 82 & 0 & 0,0 & 5 & 7,91 & 69 & 70 \\
\hline BB Energie- en informatietechniek & 340 & 36 & 75 & 0 & 0,5 & - & - & - & - \\
\hline
\end{tabular}


Tabel B4.1 (vervolg)

Enkele kernindicatoren

\begin{tabular}{|c|c|c|c|c|c|c|c|c|c|}
\hline \multirow[t]{2}{*}{ Opleidingsrichting } & \multirow[t]{2}{*}{$\begin{array}{r}\text { opgehoogd } \\
\text { aantal } \\
\text { populatie }\end{array}$} & \multirow{2}{*}{$\begin{array}{r}\text { verder } \\
\text { leren } \\
\\
\%\end{array}$} & \multirow{2}{*}{$\begin{array}{r}\text { zelfde } \\
\text { opleiding } \\
\text { opnieuw? } \\
\%\end{array}$} & \multirow{2}{*}{ 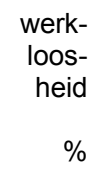 } & \multirow{2}{*}{$\begin{array}{r}\text { intrede } \\
\text { werkloos- } \\
\text { heid } \\
\text { maanden }\end{array}$} & \multirow{2}{*}{$\begin{array}{r}\text { flexibele } \\
\text { aan- } \\
\text { stelling } \\
\%\end{array}$} & \multirow{2}{*}{$\begin{array}{r}\text { bruto } \\
\text { uurloon } \\
€\end{array}$} & \multirow{2}{*}{$\begin{array}{r}\text { minimaal } \\
\text { eigen } \\
\text { niveau } \\
\%\end{array}$} & \multirow{2}{*}{$\begin{array}{r}\text { eigen/ } \\
\text { verwante } \\
\text { richting } \\
\%\end{array}$} \\
\hline & & & & & & & & & \\
\hline \multicolumn{10}{|l|}{ BBL niveau $\mathbf{1 / 2}$ (vervolg) } \\
\hline BB Energietechniek & 366 & 42 & 78 & 6 & 0,6 & 13 & 7,48 & 72 & 87 \\
\hline BB Installatie-, service- en onderhoudstechniek & 957 & 70 & 91 & 1 & 0,6 & 12 & 7,60 & 76 & 88 \\
\hline BB Procestechniek & 243 & - & 65 & 4 & 0,0 & - & 14,24 & 33 & 68 \\
\hline BB Wegvervoer & 591 & - & 82 & 0 & 0,0 & 8 & 7,90 & 57 & 72 \\
\hline BB Detailhandel/ambulante handel & 1.467 & - & 59 & 7 & 0,1 & 12 & 5,44 & 31 & 43 \\
\hline BB Opslag/magazijn & 349 & - & 72 & 8 & 1,0 & 5 & 9,20 & 18 & 71 \\
\hline BB Horeca, instellingskeuken en contractcatering & 1.398 & 36 & 74 & 0 & 0,1 & 55 & 6,93 & 84 & 65 \\
\hline BB Facilitaire dienstverlening & 154 & - & 85 & 6 & 0,1 & - & 8,90 & 47 & 87 \\
\hline BB Verpleging en verzorging & 1.839 & 32 & 83 & 0 & 0,0 & 10 & 10,02 & 90 & 79 \\
\hline BB Uiterlijke verzorging & 614 & - & 87 & 0 & 0,3 & 26 & 6,19 & 55 & 77 \\
\hline \multicolumn{10}{|l|}{ BBL niveau $3 / 4$} \\
\hline ZB Plantenteelt & 110 & - & 83 & 0 & 0,0 & - & - & - & - \\
\hline ZB Bloemschikken & 255 & - & 67 & 1 & 0,0 & 2 & 6,39 & 39 & 82 \\
\hline ZB Groene ruimte & 322 & 27 & 89 & 0 & 0,3 & - & 10,19 & 44 & 79 \\
\hline ZB Bouw & 1.396 & 18 & 83 & 0 & 0,0 & 2 & 11,07 & 45 & 74 \\
\hline ZB Grond-, water- en wegenbouw & 431 & - & 86 & 0 & 0,2 & 9 & 9,26 & 26 & 71 \\
\hline ZB Constructie-, plaatwerken/pijpenbewerken & 226 & - & 93 & 4 & 0,0 & 9 & 10,75 & 64 & 95 \\
\hline ZB Motorvoertuigen & 305 & - & 74 & 0 & 0,7 & - & 9,57 & 44 & 83 \\
\hline ZB Energie- en informatietechniek & 117 & - & 82 & 0 & 0,0 & - & 10,79 & 80 & 87 \\
\hline ZB Energietechniek & 467 & - & 83 & 0 & 0,0 & - & 9,02 & 50 & 94 \\
\hline ZB Beheer, ontwerp en management (instal. techn) & 126 & - & 89 & 0 & 0,0 & - & 12,05 & 78 & 88 \\
\hline ZB Installatie-, service- en onderhoudstechniek & 1.100 & 33 & 83 & 0 & 0,1 & 1 & 9,53 & 50 & 90 \\
\hline ZB Procestechniek & 370 & - & 87 & 5 & 0,1 & 5 & 15,61 & 31 & 90 \\
\hline ZB Automatisering & 165 & - & 77 & 12 & 0,7 & 21 & 9,98 & 93 & 100 \\
\hline ZB Detailhandel/ambulante handel & 925 & - & 60 & 6 & 0,4 & 14 & 6,36 & 30 & 46 \\
\hline ZB Opslag/magazijn & 175 & - & 73 & 7 & 0,2 & - & - & - & 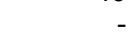 \\
\hline ZB Horeca, instellingskeuken en contractcatering & 1.118 & - & 69 & 0 & 0,3 & 15 & 8,88 & 89 & 92 \\
\hline
\end{tabular}


Tabel B4.1 (vervolg)

Enkele kernindicatoren

\begin{tabular}{|c|c|c|c|c|c|c|c|c|c|}
\hline \multirow[t]{2}{*}{ Opleidingsrichting } & \multirow[t]{2}{*}{$\begin{array}{r}\text { opgehoogd } \\
\text { aantal } \\
\text { populatie }\end{array}$} & $\begin{array}{c}\text { verder } \\
\text { leren }\end{array}$ & $\begin{array}{r}\text { zelfde } \\
\text { opleiding } \\
\text { opnieuw? }\end{array}$ & \multirow{2}{*}{$\begin{array}{c}\begin{array}{c}\text { werk- } \\
\text { loos- } \\
\text { heid } \\
\%\end{array} \\
\%\end{array}$} & \multirow{2}{*}{$\begin{array}{r}\text { intrede } \\
\text { werkloos- } \\
\text { heid } \\
\text { maanden }\end{array}$} & \multirow{2}{*}{$\begin{array}{r}\text { flexibele } \\
\text { aan- } \\
\text { stelling } \\
\%\end{array}$} & \multirow{2}{*}{$\begin{array}{r}\text { bruto } \\
\text { uurloon } \\
€\end{array}$} & \multirow{2}{*}{$\begin{array}{r}\text { minimaal } \\
\text { eigen } \\
\text { niveau } \\
\%\end{array}$} & \multirow{2}{*}{$\begin{array}{r}\text { eigen/ } \\
\text { verwante } \\
\text { richting } \\
\%\end{array}$} \\
\hline & & $\%$ & $\%$ & & & & & & \\
\hline \multicolumn{10}{|l|}{ BBL niveau $3 / 4$ (vervolg) } \\
\hline ZB Verpleging en verzorging & 3.924 & 13 & 81 & 0 & 0,0 & 2 & 10,96 & 91 & 90 \\
\hline ZB Uiterlijke verzorging & 755 & - & 95 & 0 & 0,0 & 10 & 6,50 & 46 & 82 \\
\hline MKF Bouw & 132 & - & 82 & 6 & 0,0 & - & 11,86 & 50 & 92 \\
\hline MKF Detailhandel/ambulante handel & 366 & - & 72 & 0 & 0,0 & 12 & 7,43 & 64 & 54 \\
\hline MKF Horeca, instellingskeuken en contractcatering & 23 & - & 81 & 7 & 0,4 & - & & - & \\
\hline MKF Verpleging en verzorging & 2.306 & - & 82 & 0 & 0,1 & 2 & 11,15 & 95 & 95 \\
\hline MKF Sociaal-pedagogisch werk & 474 & - & 84 & 1 & 0,6 & 11 & 12,61 & 85 & 93 \\
\hline Specialist Energietechniek & 240 & - & 87 & 1 & 0,0 & - & 12,89 & 81 & 91 \\
\hline Specialist Verpleging en verzorging & 98 & - & 85 & 0 & 0,0 & 5 & 12,73 & 94 & 89 \\
\hline
\end{tabular}

$\mathrm{x}=$ vraag niet opgenomen

Zie ook tolichting badzijde 48 en de tabellen C. 5, B2 1, B1.4, B3.1, B3. 3, B3.7, B3. 8 en B3. 

C. Respons 



\section{Inhoud}

C.1 Ongewogen aantal respondenten verbijzonderd naar bestemming per opleidingssector

C.2 Naar landelijke populatie gewogen aantal schoolverlaters verbijzonderd naar bestemming per opleidingssector

C.3 Responspercentage per opleidingssector

C.4 Ongewogen aantal respondenten verbijzonderd naar bestemming per opleidingsrichting

C.5 Naar landelijke populatie gewogen aantal schoolverlaters verbijzonderd naar bestemming per opleidingsrichting

C.6 Responspercentage per opleidingsrichting 
Tabel C. 1

Ongewogen aantal respondenten verbijzonderd naar bestemming per opleidingssector

\begin{tabular}{|c|c|c|c|c|c|c|c|}
\hline Opleidingssector & studie & BBL & $\begin{array}{r}\text { betaald } \\
\text { werk }\end{array}$ & $\begin{array}{r}\text { werk- } \\
\text { loos }\end{array}$ & anders & $\begin{array}{r}\text { on- } \\
\text { bekend }\end{array}$ & totaal \\
\hline AVO & 1.521 & 85 & 140 & 12 & 35 & 21 & 1.814 \\
\hline MAVO & 559 & 66 & 73 & 7 & 20 & 4 & 729 \\
\hline HAVO & 463 & 13 & 50 & 3 & 8 & 8 & 545 \\
\hline VWO & 499 & 6 & 17 & 2 & 7 & 9 & 540 \\
\hline VBO & 1.082 & 537 & 499 & 40 & 55 & 38 & 2.251 \\
\hline IVBO & 156 & 100 & 141 & 14 & 10 & 5 & 426 \\
\hline Landbouw & 593 & 205 & 240 & 21 & 28 & 23 & 1.110 \\
\hline Techniek & 124 & 151 & 67 & 3 & 9 & 6 & 360 \\
\hline Economie & 81 & 23 & 20 & 1 & 2 & 2 & 129 \\
\hline Gezondheidszorg & 128 & 58 & 31 & 1 & 6 & 2 & 226 \\
\hline BOL niveau $1 / 2$ & 259 & 119 & 388 & 31 & 32 & 15 & 844 \\
\hline Landbouw & 21 & 7 & 67 & 7 & 8 & 2 & 112 \\
\hline Techniek & 54 & 36 & 89 & 6 & 5 & 5 & 195 \\
\hline Economie & 119 & 59 & 172 & 14 & 13 & 6 & 383 \\
\hline Gezondheidszorg & 65 & 17 & 60 & 4 & 6 & 2 & 154 \\
\hline BOL niveau $3 / 4$ & 1.838 & 207 & 2.553 & 83 & 110 & 86 & 4.877 \\
\hline Landbouw & 355 & 64 & 609 & 18 & 43 & 37 & 1.126 \\
\hline Techniek & 544 & 32 & 653 & 30 & 23 & 18 & 1.300 \\
\hline Economie & 430 & 31 & 511 & 19 & 15 & 12 & 1.018 \\
\hline Gezondheidszorg & 164 & 45 & 432 & 4 & 14 & 12 & 671 \\
\hline Gedrag en maatschappij & 345 & 35 & 348 & 12 & 15 & 7 & 762 \\
\hline BBL niveau $1 / 2$ & 33 & 283 & 899 & 31 & 25 & 13 & 1.284 \\
\hline Landbouw & 8 & 58 & 200 & 5 & 2 & 5 & 278 \\
\hline Techniek & 18 & 154 & 405 & 14 & 11 & 7 & 609 \\
\hline Economie & 6 & 47 & 183 & 11 & 6 & 0 & 253 \\
\hline Gezondheidszorg & 1 & 24 & 111 & 1 & 6 & 1 & 144 \\
\hline BBL niveau $3 / 4$ & 46 & 71 & 1.159 & 15 & 27 & 11 & 1.329 \\
\hline Landbouw & 14 & 9 & 164 & 1 & 4 & 0 & 192 \\
\hline Techniek & 13 & 32 & 408 & 6 & 6 & 7 & 472 \\
\hline Economie & 11 & 7 & 184 & 6 & 4 & 3 & 215 \\
\hline Gezondheidszorg & 6 & 23 & 317 & 0 & 10 & 1 & 357 \\
\hline Gedrag en maatschappij & 2 & 0 & 86 & 2 & 3 & 0 & 93 \\
\hline HBO & 2.052 & $\mathbf{x}$ & 10.854 & 305 & 471 & 346 & 14.028 \\
\hline Landbouw & 138 & $\mathrm{x}$ & 606 & 19 & 36 & 29 & 828 \\
\hline Onderwijs & 167 & $\mathrm{x}$ & 1.679 & 25 & 41 & 21 & 1.933 \\
\hline Techniek & 421 & $\mathrm{x}$ & 1.803 & 53 & 50 & 40 & 2.367 \\
\hline Economie & 830 & $\mathrm{x}$ & 3.144 & 103 & 134 & 113 & 4.324 \\
\hline Gezondheidszorg & 175 & $\mathrm{x}$ & 1.409 & 23 & 44 & 39 & 1.690 \\
\hline Gedrag en maatschappij & 208 & $\mathrm{x}$ & 1.647 & 37 & 68 & 54 & 2.014 \\
\hline Taal en cultuur & 113 & $x$ & 566 & 45 & 98 & 50 & 872 \\
\hline wo & 316 & $\mathbf{x}$ & 7.484 & 211 & 232 & 155 & 8.398 \\
\hline Landbouw & 8 & $\mathrm{x}$ & 247 & 13 & 4 & 3 & 275 \\
\hline Techniek & 32 & $\mathrm{x}$ & 1.130 & 30 & 35 & 16 & 1.243 \\
\hline Economie & 23 & $\mathrm{x}$ & 1.146 & 22 & 19 & 16 & 1.226 \\
\hline Gezondheidszorg & 48 & $\mathrm{x}$ & 932 & 13 & 21 & 26 & 1.040 \\
\hline Gedrag en maatschappij & 58 & $\mathrm{x}$ & 1.566 & 50 & 73 & 38 & 1.785 \\
\hline Taal en cultuur & 68 & $\mathrm{x}$ & 800 & 42 & 48 & 15 & 973 \\
\hline
\end{tabular}


Tabel C.1 (vervolg)

Ongewogen aantal respondenten verbijzonderd naar bestemming per opleidingssector

\begin{tabular}{lrrrrrrr}
\hline Opleidingssector & studie & BBL & $\begin{array}{r}\text { betaald } \\
\text { werk }\end{array}$ & $\begin{array}{r}\text { werk- } \\
\text { loos }\end{array}$ & anders & $\begin{array}{r}\text { on- } \\
\text { bekend }\end{array}$ & totaal \\
\hline WO (vervolg) & & & & & & & \\
Recht en openbare orde & 24 & $\mathrm{x}$ & 982 & 17 & 19 & 23 & 1.065 \\
Natuurwetenschappen & 55 & $\mathrm{x}$ & 681 & 24 & 13 & 18 & 791 \\
Totaal & $\mathbf{7 . 1 4 7}$ & $\mathbf{1 . 3 0 2}$ & $\mathbf{2 3 . 9 7 6}$ & $\mathbf{7 2 8}$ & $\mathbf{9 8 7}$ & $\mathbf{6 8 5}$ & $\mathbf{3 4 . 8 2 5}$ \\
\hline
\end{tabular}

$\mathrm{x}=$ antwoordcategorie niet opgenomen

Toelichting

De aantallen in deze tabel betreffen het feitelijke aantal respondenten van wie de gegevens in deze rapportage zijn opgenomen. 
Tabel C.2

Naar landelijke populatie gewogen aantal schoolverlaters verbijzonderd naar bestemming per opleidingssector

\begin{tabular}{|c|c|c|c|c|c|c|c|}
\hline & studie & $\mathrm{BBL}$ & $\begin{array}{r}\text { betaald } \\
\text { werk }\end{array}$ & $\begin{array}{c}\text { werk- } \\
\text { loos }\end{array}$ & anders & $\begin{array}{l}\text { on- } \\
\text { bekend }\end{array}$ & totaal \\
\hline $\begin{array}{l}\text { AVO } \\
\text { MAVO } \\
\text { HAVO } \\
\text { VWO }\end{array}$ & $\begin{array}{l}82.196 \\
31.598 \\
26.144 \\
24.454\end{array}$ & $\begin{array}{r}4.745 \\
3.725 \\
732 \\
288\end{array}$ & $\begin{array}{r}7.842 \\
4.174 \\
2.816 \\
852\end{array}$ & $\begin{array}{l}623 \\
388 \\
130 \\
104\end{array}$ & $\begin{array}{r}2.025 \\
1.240 \\
444 \\
342\end{array}$ & $\begin{array}{l}761 \\
237 \\
280 \\
244\end{array}$ & $\begin{array}{l}\mathbf{9 8 . 1 9 3} \\
41.363 \\
30.547 \\
26.283\end{array}$ \\
\hline $\begin{array}{l}\text { VBO } \\
\text { IVBO } \\
\text { Landbouw } \\
\text { Techniek } \\
\text { Economie } \\
\text { Gezondheidszorg }\end{array}$ & $\begin{array}{r}20.419 \\
1.177 \\
2.030 \\
5.571 \\
5.182 \\
6.459\end{array}$ & $\begin{array}{r}10.772 \\
761 \\
658 \\
5.962 \\
1.346 \\
2.044\end{array}$ & $\begin{array}{r}7.228 \\
1.114 \\
793 \\
2.871 \\
1.212 \\
1.238\end{array}$ & $\begin{array}{r}352 \\
96 \\
68 \\
116 \\
52 \\
22\end{array}$ & $\begin{array}{r}1.199 \\
101 \\
95 \\
461 \\
143 \\
398\end{array}$ & $\begin{array}{r}476 \\
21 \\
70 \\
222 \\
73 \\
91\end{array}$ & $\begin{array}{r}40.446 \\
3.270 \\
3.713 \\
15.203 \\
8.008 \\
10.252\end{array}$ \\
\hline $\begin{array}{l}\text { BOL niveau } 1 / 2 \\
\text { Landbouw } \\
\text { Techniek } \\
\text { Economie } \\
\text { Gezondheidszorg }\end{array}$ & $\begin{array}{r}4.267 \\
79 \\
373 \\
2.388 \\
1.428\end{array}$ & $\begin{array}{r}1.916 \\
38 \\
487 \\
961 \\
430\end{array}$ & $\begin{array}{r}5.901 \\
241 \\
835 \\
3.083 \\
1.743\end{array}$ & $\begin{array}{r}543 \\
24 \\
76 \\
365 \\
77\end{array}$ & $\begin{array}{r}561 \\
39 \\
21 \\
328 \\
171\end{array}$ & $\begin{array}{r}231 \\
10 \\
58 \\
77 \\
87\end{array}$ & $\begin{array}{r}13.418 \\
431 \\
1.851 \\
7.202 \\
3.935\end{array}$ \\
\hline $\begin{array}{l}\text { BOL niveau } \mathbf{3 / 4} \\
\text { Landbouw } \\
\text { Techniek } \\
\text { Economie } \\
\text { Gezondheidszorg } \\
\text { Gedrag en maatschappij }\end{array}$ & $\begin{array}{r}21.000 \\
1.206 \\
5.454 \\
7.900 \\
1.642 \\
4.798\end{array}$ & $\begin{array}{r}2.287 \\
251 \\
266 \\
618 \\
546 \\
606\end{array}$ & $\begin{array}{r}24.785 \\
2.141 \\
4.888 \\
7.930 \\
5.064 \\
4.762\end{array}$ & $\begin{array}{r}875 \\
61 \\
256 \\
335 \\
54 \\
169\end{array}$ & $\begin{array}{l}929 \\
147 \\
129 \\
272 \\
185 \\
195\end{array}$ & $\begin{array}{r}552 \\
133 \\
139 \\
54 \\
144 \\
82\end{array}$ & $\begin{array}{r}\mathbf{5 0 . 4 2 9} \\
3.938 \\
11.133 \\
17.110 \\
7.636 \\
10.612\end{array}$ \\
\hline $\begin{array}{l}\text { BBL niveau } \mathbf{1 / 2} \\
\text { Landbouw } \\
\text { Techniek } \\
\text { Economie } \\
\text { Gezondheidszorg }\end{array}$ & $\begin{array}{r}652 \\
43 \\
434 \\
142 \\
33\end{array}$ & $\begin{array}{r}4.660 \\
346 \\
2.941 \\
899 \\
474\end{array}$ & $\begin{array}{r}14.393 \\
1.289 \\
7.139 \\
3.864 \\
2.101\end{array}$ & $\begin{array}{r}482 \\
26 \\
277 \\
163 \\
16\end{array}$ & $\begin{array}{r}428 \\
32 \\
216 \\
114 \\
65\end{array}$ & $\begin{array}{r}214 \\
35 \\
163 \\
0 \\
16\end{array}$ & $\begin{array}{r}\mathbf{2 0 . 8 2 8} \\
1.771 \\
11.170 \\
5.182 \\
2.705\end{array}$ \\
\hline $\begin{array}{l}\text { BBL niveau } 3 / 4 \\
\text { Landbouw } \\
\text { Techniek } \\
\text { Economie } \\
\text { Gezondheidszorg } \\
\text { Gedrag en maatschappij }\end{array}$ & $\begin{array}{r}617 \\
96 \\
180 \\
144 \\
182 \\
16\end{array}$ & $\begin{array}{r}1.055 \\
49 \\
494 \\
96 \\
417 \\
0\end{array}$ & $\begin{array}{r}15.772 \\
791 \\
5.309 \\
2.786 \\
6.308 \\
577\end{array}$ & $\begin{array}{r}155 \\
3 \\
73 \\
73 \\
0 \\
7\end{array}$ & $\begin{array}{r}323 \\
26 \\
57 \\
46 \\
175 \\
18\end{array}$ & $\begin{array}{r}153 \\
0 \\
112 \\
24 \\
17 \\
0\end{array}$ & $\begin{array}{r}18.075 \\
964 \\
6.225 \\
3.169 \\
7.099 \\
618\end{array}$ \\
\hline $\begin{array}{l}\text { HBO } \\
\text { Landbouw } \\
\text { Onderwijs } \\
\text { Techniek } \\
\text { Economie } \\
\text { Gezondheidszorg } \\
\text { Gedrag en maatschappij } \\
\text { Taal en cultuur }\end{array}$ & $\begin{array}{r}6.410 \\
291 \\
591 \\
1.637 \\
2.565 \\
443 \\
644 \\
239\end{array}$ & $\begin{array}{l}\mathbf{x} \\
\mathrm{X} \\
\mathrm{X} \\
\mathrm{X} \\
\mathrm{X} \\
\mathrm{X} \\
\mathrm{X} \\
\mathrm{X}\end{array}$ & $\begin{array}{r}33.301 \\
1.286 \\
6.087 \\
6.825 \\
9.430 \\
3.627 \\
4.953 \\
1.094\end{array}$ & $\begin{array}{r}946 \\
41 \\
100 \\
231 \\
316 \\
67 \\
111 \\
80\end{array}$ & $\begin{array}{r}1.310 \\
76 \\
143 \\
184 \\
403 \\
112 \\
204 \\
189\end{array}$ & $\begin{array}{r}968 \\
65 \\
66 \\
151 \\
330 \\
93 \\
160 \\
103\end{array}$ & $\begin{array}{r}42.935 \\
1.758 \\
6.986 \\
9.028 \\
13.043 \\
4.343 \\
6.071 \\
1.705\end{array}$ \\
\hline $\begin{array}{l}\text { Wo } \\
\text { Landbouw } \\
\text { Techniek } \\
\text { Economie } \\
\text { Gezondheidszorg } \\
\text { Gedrag en maatschappij } \\
\text { Taal en cultuur } \\
\text { Recht en openbare orde } \\
\text { Natuurwetenschappen }\end{array}$ & $\begin{array}{r}709 \\
18 \\
72 \\
52 \\
108 \\
130 \\
153 \\
54 \\
123\end{array}$ & $\begin{array}{l}x \\
x \\
x \\
x \\
x \\
x \\
x \\
x \\
x\end{array}$ & $\begin{array}{r}16.798 \\
554 \\
2.536 \\
2.572 \\
2.092 \\
3.515 \\
1.796 \\
2.204 \\
1.529\end{array}$ & $\begin{array}{r}474 \\
29 \\
67 \\
49 \\
29 \\
112 \\
94 \\
38 \\
54\end{array}$ & $\begin{array}{r}520 \\
9 \\
78 \\
42 \\
47 \\
164 \\
108 \\
42 \\
29\end{array}$ & $\begin{array}{r}348 \\
7 \\
36 \\
36 \\
58 \\
85 \\
34 \\
52 \\
40\end{array}$ & $\begin{array}{r}18.850 \\
617 \\
2.790 \\
2.752 \\
2.334 \\
4.007 \\
2.184 \\
2.390 \\
1.775\end{array}$ \\
\hline Totaal & 136.270 & 25.436 & 126.020 & 4.450 & 7.295 & 3.704 & 303.175 \\
\hline
\end{tabular}

Toelichting

De aantallen in deze tabel zijn zodanig opgehoogd dat een representatief beeld wordt gegeven van de totale populatie van schoolverlaters. 
Tabel C.3

Responspercentage per opleidingssector

Opleidingssector

AVO

MAVO

HAVO

VWO

VBO

IVBO

Landbouw

Techniek

Economie

Gezondheidszorg

BOL niveau 1/2

Landbouw

Techniek

Economie

Gezondheidszorg

BOL niveau $3 / 4$

Landbouw

Techniek

Economie

Gezondheidszorg

Gedrag en maatschappij

BBL niveau 1/2

Landbouw

Techniek

Economie

Gezondheidszorg

BBL niveau $3 / 4$

Landbouw

Techniek

Economie

Gezondheidszorg

Gedrag en maatschappij

HBO

Landbouw

Onderwijs

Techniek

Economie

Gezondheidszorg

Gedrag en maatschappij

Taal en cultuur

WO

Landbouw

Techniek

Economie

Gezondheidszorg

Gedrag en maatschappij

Taal en cultuur

Recht en openbare orde

Natuurwetenschappen

Totaal

\section{Toelichting}

De responspercentages geven een beeld van het aandeel van de uitgezette vragenlijsten dat bruikbaar retour is gekomen. De responspercentages van het WO hebben betrekking op 11 universiteiten. 
Tabel C. 4

Ongewogen aantal respondenten verbijzonderd naar bestemming per opleidingsrichting

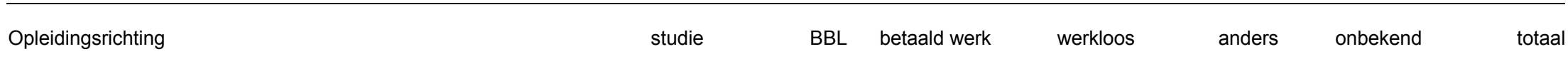

VBO

IVBO Landbouw en natuurlijke omgeving

IVBO Bouwtechniek

IVBO Verzorging

Landbouw en natuurlijke omgeving

Bouwtechniek

Mechanische techniek

Elektrotechniek

Motorvoertuigentechniek

Consumptieve techniek

Nautische opleidingen

Administratie

Verkoop

Verzorging

Uiterlijke verzorging

$\begin{array}{rrr}134 & & \\ 2 & 85 & 117 \\ 10 & 6 & 6 \\ 593 & 2 & 9 \\ 26 & 205 & 240 \\ 18 & 48 & 30 \\ 42 & 11 & 7 \\ 11 & 24 & 10 \\ 10 & 16 & 7 \\ 11 & 21 & 5 \\ 50 & 17 & 2 \\ 23 & 8 & 9 \\ 93 & 14 & 10 \\ 21 & 33 & 17 \\ & 17 & 10\end{array}$

BOL niveau $1 / 2$

$A B$ Motorvoertuigen

$A B$ Beveiliging

$A B$ Secretarieel

$A B$ Verpleging en verzorging

BB Plantenteelt

BB Bloemschikken

BB Dierverzorging en veterinaire ondersteuning

BB Houtbewerking en woninginrichting

BB Reclame, presentatie en communicatie

BB Motorvoertuigen

BB Graf. techn, communicatie, audiovisueel en multimedia

BB Bedrijfsadministratie

BB Secretarieel

BB Detailhandel/ambulante handel

117
6
9
240
30
7
10
7
5
2
9
10
17
10

12
1
1
21
1
0
1
0
1
0
0
1
0
1

8
0
1
28
2
2
2
1
1
0
2
0
5
0

361
15
23
110
108
40
81
36
38
30
71
48
149
49


Tabel C.4 (vervolg)

Ongewogen aantal respondenten verbijzonderd naar bestemming per opleidingsrichting

\begin{tabular}{|c|c|c|c|}
\hline Opleidingsrichting & studie & BBL & betaald werk \\
\hline
\end{tabular}

BOL niveau 1/2 (vervolg)

BB Horeca, instellingskeuken en contractcatering

BB Facilitaire dienstverlening

$\begin{array}{rl}45 & 42 \\ 3 & \\ 49 & \\ & \\ 7 & \\ 10 & \\ 4 & \\ 15 & \\ 18 & \\ 3 & \\ 14 & \\ 10 & \\ 2 & \\ 3 & \\ 11 & \\ 11 & \\ 14 & \\ 15 & \\ 33 & \\ 10 & \\ 44 & \\ 77 & \\ 20 & \\ 13 & \\ 23 & \\ 6 & \\ 78 & \\ 23 & \\ 99 & \\ 44 & \\ 20 & \end{array}$

BOL niveau $3 / 4$

ZB Plantenteelt

ZB Veehouderij

ZB Levensmiddelentechnologie

schikken

ZB Dierverzorging en veterinaire ondersteuning

ZB Paardenhouderij en paardensport

ZB Groene ruimte

ZB Werktuigbouwkunde

ZB Graf. techn, communicatie, audiovisueel en multimedia

ZB Scheepvaart

ZB Bedrijfsadministratief

ZB Detailhandel/ambulante handel

ZB Groothandel/distributie

ZB Toerisme, recreatie en reizen

ZB Verpleging en verzorging

ZB Uiterlijke verzorging

KF Levensmiddelentechnologie

KF Bloemschikken

KF Dierverzorging en veterinaire ondersteuning

KF Paardenhouderij en paardensport

KF Groene ruimte

MKF Bouw

MKF Houtbewerking en woninginrichting

MKF Grond-, water- en wegenbouw

$\begin{array}{rrrrr}40 & 4 & 3 & 1 & 135 \\ 11 & 0 & 1 & 0 & 15 \\ 39 & 2 & 1 & 1 & 108 \\ & & & & \\ 46 & 1 & 2 & 2 & 66 \\ 49 & 0 & 5 & 6 & 78 \\ 9 & 0 & 0 & 0 & 15 \\ 57 & 2 & 6 & 2 & 87 \\ 33 & 2 & 7 & 0 & 65 \\ 11 & 1 & 2 & 0 & 19 \\ 62 & 3 & 2 & 2 & 94 \\ 8 & 0 & 0 & 0 & 18 \\ 15 & 1 & 0 & 0 & 18 \\ 23 & 0 & 0 & 2 & 29 \\ 19 & 0 & 0 & 1 & 32 \\ 11 & 0 & 2 & 1 & 25 \\ 7 & 0 & 1 & 2 & 24 \\ 43 & 3 & 0 & 0 & 62 \\ 135 & 1 & 6 & 4 & 206 \\ 36 & 2 & 1 & 1 & 52 \\ 41 & 0 & 5 & 5 & 96 \\ 96 & 4 & 7 & 8 & 199 \\ 25 & 0 & 2 & 1 & 50 \\ 40 & 0 & 1 & 2 & 60 \\ 38 & 2 & 0 & 2 & 66 \\ 16 & 0 & 1 & 0 & 24 \\ 76 & 3 & 2 & 6 & 171 \\ 10 & 0 & 1 & 1 & 36 \\ 69 & 3 & 1 & 4 & 178 \\ 111 & 4 & 6 & 0 & 49 \\ 26 & 2 & 0 & 0 & \end{array}$


Tabel C.4 (vervolg)

Ongewogen aantal respondenten verbijzonderd naar bestemming per opleidingsrichting

\begin{tabular}{|c|c|c|c|}
\hline Opleidingsrichting & studie & BBL & betaald werk \\
\hline
\end{tabular}

BOL niveau 3/4 (vervolg)

MKF Beschermings- en afwerkingstechnieken

MKF Operationele techniek

MKF Werktuigbouwkunde

MKF Motorvoertuigen

MKF Energie- en informatietechniek

MKF Energietechniek

hniek

MKF Graf. techn, communicatie, audiovisueel en multimedia

MKF Laboratoriumtechniek

MKF Procestechniek

MKF Scheepvaart

MKF Transport en logistiek

MKF Automatisering

MKF Bedrijfsadministratief

MKF Commercieel

MKF Economisch-juridisch

MKF Secretarieel

MKF Detailhandel/ambulante handel

MKF Detaihandelambulante

MKF Horeca, instellingskeuken en contractcatering

MKF Toerisme, recreatie en reizen

MKF Assistenten gezondheidszorg

MKF Facilitaire dienstverlening

MKF Sport en bewegen

MKF Verpleging en verzorging

MKF Maatschappelijke dienstverlening

MKF Sociaal-pedagogisch werk algemeen

MKF Sociaal-juridisch werk

(2)

betaald werk

60
88
14
23
15
16
10
44
25
45
8
18
28
9
30
48
6
71
52
8
93
97
134
11
40
76
8
308
18

\section{$B B L$ niveau 1/2}


Tabel C.4 (vervolg)

Ongewogen aantal respondenten verbijzonderd naar bestemming per opleidingsrichting

\begin{tabular}{llllll}
\hline Opleidingsrichting & studie & bBL & betaald werk
\end{tabular}

$B B L$ niveau $\mathbf{1 / 2}$ (vervolg)

AB Beveiliging

AB Detailhandel/ambulante handel

$A B$ Verpleging en verzorging

BB Plantenteelt

BB Bloemschikken

BB Groene ruimte

BB Bouw

BB Houtbewerking en woninginrichting

BB Grond-, water en wegenbouw

BB Beschermings- en afwerkingstechnieken

BB Constructie-, plaatwerken/pijpenbewerken

BB Montage/onderhoud/operationele techniek

BB Motorvoertuigen

BB Energie- en informatietechniek

BB Energietechniek

BB Installatie-, service- en onderhoudstechniek

BB Procestechniek

BB Wegvervoer

BB Detailhandel/ambulante handel

BB Opslag/magazijn

BB Horeca, instellingskeuken en contractcatering

BB Facilita dienstverlening

$B B$ Verpleging en verzorging

BB Uiterlijke verzorging

28
18
13
28
50
75
70
28
9
12
30
11
26
10
23
25
21
46
59
20
29
18
63
17

ZB Plantenteelt

ZB Bloemschikken

ZB Groene ruimte

ZB Bouw

ZB Grond-, water- en wegenbouw

ZB Constructie-, plaatwerken/pijpenbewerken 
Tabel C.4 (vervolg)

Ongewogen aantal respondenten verbijzonderd naar bestemming per opleidingsrichting

\begin{tabular}{llllll}
\hline Opleidingsrichting & studie & bBL & betaald werk
\end{tabular}

BBL niveau 3/4 (vervolg)

ZB Motorvoertuigen

ZB Energie- en informatietechniek

ZB Energietechniek

ZB Beheer, ontwerp en management (instal. techn)

ZB Installatie-, service- en onderhoudstechniek

ZB Procestechniek

ZB Automatisering

ZB Detailhandel/ambulante handel

ZB Opslag/magazijn

ZB Horeca, instellingskeuken en contractcatering

$Z B$ Verpleging en verzorging

ZB Uiterlijke verzorging

MKF Bouw

MKF Detailhandel/ambulante handel

MKF Horeca, instellingskeuken en contractcatering

MKF Verpleging en verzorging

Specialist Energietechniek

Specialist Verpleging en verzorging

18
16
23
18
47
22
17
51
14
44
197
32
13
16
11
64
77
24
20

19

0
0
2
0
0
0
3
1
1
1
1
1
1
2
1
4
1
1
0

0
1
0
0
1
0
0
1
0
1
9
1
1
0
1
0
2
0
0

$\begin{array}{lr}0 & 19 \\ 0 & 18 \\ 0 & 29 \\ 0 & 19 \\ 0 & 55 \\ 0 & 24 \\ 1 & 23 \\ 1 & 60 \\ 0 & 16 \\ 0 & 47 \\ 1 & 229 \\ 0 & 34 \\ 1 & 17 \\ 0 & 19 \\ 1 & 16 \\ 0 & 70 \\ 0 & 82 \\ 0 & 26 \\ 0 & 20 \\ & \end{array}$


Tabel C. 5

Naar landelijke populatie gewogen aantal schoolverlaters verbijzonderd naar bestemming per opleidingsrichting

\begin{tabular}{llrl}
\hline Opleidingsrichting & studie $\quad$ BBL & $\begin{array}{c}\text { betald werk } \\
\text { werkloos anders onbekend totaal }\end{array}$
\end{tabular}

VBO

IVBO Landbouw en natuurlijke omgeving

IVBO Bouwtechniek

IVBO Verzorging

Landbouw en natuurlijke omgeving

Bouwtechniek

Mechanische techniek

Elektrotechniek

Motorvoertuigentechniek

Consumptieve techniek

Nautische opleidingen

Administratie

Verkoop

Verzorging

Uiterlijke verzorging

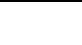

BOL niveau $1 / 2$

AB Motorvoertuigen

$A B$ Beveiliging

$A B$ Verpleging en verzorging

BB Bloemschikken

BB Bloemschikken

BB Dierverzorging en veterinaire ondersteuning

BB Groene ruimte

BB Houtbewerking en woninginrichting

BB Reclame, presentatie en communicatie

BB Motorvoertuigen

BB Graf. techn, communicatie, audiovisueel en multimedia

BB Bedrijfsadministratie

$\begin{array}{rrr}631 & 408 & 5 \\ 39 & 124 & 124 \\ 206 & 41 & 185 \\ 2.030 & 658 & 793 \\ 962 & 1.774 & 1.166 \\ 1.111 & 679 & 432 \\ 2.029 & 1.180 & 463 \\ 658 & 957 & 4 \\ 491 & 1.031 & 246 \\ 88 & 127 & \\ 3.586 & 574 & 645 \\ 1.185 & 721 & 5 \\ 5.740 & 1.536 & 880 \\ 480 & 403 & 226\end{array}$

$\begin{array}{rr}542 & 55 \\ 124 & 21 \\ 185 & 21 \\ 793 & 68 \\ 1.166 & 31 \\ 432 & \\ 463 & 36 \\ 419 & \\ 246 & 49 \\ 15 & \\ 645 & \\ 515 & 52 \\ 880 & \\ 226 & \end{array}$

$\begin{array}{rrrr}55 & 36 & 21 & 1.693 \\ 21 & 0 & 0 & 307 \\ 21 & 21 & 0 & 474 \\ 68 & 95 & 70 & 3.713 \\ 31 & 76 & 45 & 4.053 \\ 0 & 123 & 123 & 2.469 \\ 36 & 102 & 52 & 3.862 \\ 0 & 60 & 1 & 2.095 \\ 49 & 49 & 0 & 1.866 \\ 0 & 0 & 0 & 230 \\ 0 & 143 & 73 & 5.021 \\ 52 & 0 & 0 & 2.472 \\ 0 & 397 & 90 & 8.642 \\ 22 & 0 & 0 & 1.131\end{array}$

BB Secretarieel

$\begin{array}{rrr}17 & 75 & 41 \\ 177 & 14 & 463 \\ 364 & 0 & 208 \\ 40 & 3 & 17 \\ 3 & 8 & 66 \\ 10 & 6 & 57 \\ 36 & 0 & 11 \\ 0 & 24 & 70 \\ 45 & 28 & 83 \\ 51 & 0 & 27 \\ 12 & 84 & 84 \\ 6 & 0 & 30 \\ 395 & 180 & 395 \\ 370 & 111 & 333\end{array}$

0
28
208
3
0
1
11
4
13
3
12
4
36
0

8
14
0
3
7
3
24
0
6
3
0
4
0
74

141
703
780
66
84
84
86
99
175
83
192
44
1.007
887 
Tabel C.5 (vervolg)

Naar landelijke populatie gewogen aantal schoolverlaters verbijzonderd naar bestemming per opleidingsrichting

Opleidingsrichting studie BBL $\begin{array}{r}\text { betald werk } \\ \text { werkloos anders onbekend totaal }\end{array}$

BOL niveau $1 / 2$ (vervolg)

BB Detailhandel/ambulante handel

BB Horeca, instellingskeuken en contractcatering

BB Facilitaire dienstverlening

BB Verpleging en verzorging

BOL niveau $3 / 4$

ZB Plantenteelt

ZB Veehouderij

ZB Levensmiddelentechnologie

ZB Bloemschikken

ZB Dierverzorging en veterinaire ondersteuning

ZB Paardenhouderij en paardensport

ZB Groene ruimte

ZB Werktuigbouwkunde

ZB Graf. techn, communicatie, audiovisueel en multimedia

ZB Scheepvaart

ZB Bedrijfsadr

ZB Detailhandel/ambulante handel

ZB Groothandel/distributie

ZB Toerisme, recreatie en reizen

ZB Verpleging en verzorging

ZB Uiterlijke verzorging

KF Plantenteelt

KF Veehouderij

KF Levensmiddelentechnologie

KF Bloemschikken

KF Dierverzorging en veterinaire ondersteuning

KF Paardenhouderij en paardensport

KF Groene ruimte

KF Milieutoezicht

MKF Bouw

$\begin{array}{rrr}494 & 164 & 905 \\ 343 & 429 & 359 \\ 113 & 0 & 448 \\ 1.241 & 426 & 1.112 \\ & & \\ & & \\ 29 & 37 & 174 \\ 50 & 38 & 204 \\ 19 & 11 & 43 \\ 54 & 19 & 206 \\ 50 & 16 & 114 \\ 8 & 7 & 39 \\ 57 & 45 & 247 \\ 18 & 0 & 14 \\ 9 & 0 & 69 \\ 5 & 2 & 48 \\ 349 & 32 & 602 \\ 122 & 0 & 122 \\ 156 & 0 & 78 \\ 153 & 10 & 477 \\ 446 & 347 & 1.846 \\ 237 & 35 & 880 \\ 144 & 5 & 121 \\ 247 & 21 & 286 \\ 82 & 8 & 95 \\ 31 & 14 & 131 \\ 76 & 3 & 133 \\ 28 & 5 & 75 \\ 255 & 20 & 246 \\ 77 & 2 & 27 \\ 1.054 & 23 & 718\end{array}$

$\begin{array}{rrrr}0 & 206 & 41 & 1.810 \\ 68 & 17 & 1 & 1.217 \\ 0 & 48 & 0 & 609 \\ 40 & 21 & 54 & 2.895\end{array}$

1.054

4
0
0
7
6
3
12
0
5
0
0
0
0
71
13
35
0
10
0
0
7
0
10
0
33

$\begin{array}{rr}5 & 263 \\ 33 & 342 \\ 0 & 73 \\ 7 & 316 \\ 0 & 204 \\ 0 & 64 \\ 5 & 375 \\ 0 & 32 \\ 0 & 83 \\ 4 & 60 \\ 1 & 984 \\ 11 & 278 \\ 2 & 247 \\ 0 & 710 \\ 55 & 2.788 \\ 33 & 1.238 \\ 18 & 305 \\ 23 & 606 \\ 1 & 194 \\ 12 & 190 \\ 7 & 226 \\ 0 & 112 \\ 18 & 556 \\ 3 & 112 \\ 37 & 1.878\end{array}$


Tabel C.5 (vervolg)

Naar landelijke populatie gewogen aantal schoolverlaters verbijzonderd naar bestemming per opleidingsrichting

\begin{tabular}{llrr}
\hline Opleidingsrichting & studie & $\begin{array}{r}\text { bBL } \\
\text { werk }\end{array}$ werkloos anders onbekend
\end{tabular}

BOL niveau 3/4 (vervolg)

MKF Houtbewerking en woninginrichting

MKF Grond-, water- en wegenbouw

MKF Beschermings- en afwerkingstechnieken

MKF Reclame, presentatie en communicatie

MKF Operationele techniek

MKF Werktuigbouwkunde

MKF Motorvoertuigen

MKF Energie- en informatietechniek

MKF Energietechnie

MKF Informatietechniek

MKF Graf. techn, communicatie, audiovisueel en multimedia

MKF Laboratoriumtechniek

MKF Procestechniek

MKF Scheepvaart

MKF Transport en logistiek

MKF Automatisering

MKF Bedrijfsadministratief

MKF Commercieel

MKF Economisch-juridisch

MKF Secretarieel

MKF Detailhandel/ambulante hande

MKF Groothandel/distributie

MKF Horeca, instellingskeuken en contractcatering

MKF Toerisme, recreatie en reizen

MKF Assistenten gezondheidszorg

MKF Facilitaire dienstverlening

MKF Sport en bewegen

MKF Verpleging en verzorging

MKF Maatschappelijke dienstverlening

MKF Sociaal-pedagogisch werk algemeen

MKF Sociaal-juridisch werk

$\begin{array}{rrr}89 & 6 & 239 \\ 202 & 10 & 263 \\ 47 & 13 & 152 \\ 226 & 9 & 234 \\ 7 & 0 & 33 \\ 844 & 22 & 490 \\ 216 & 54 & 271 \\ 707 & 21 & 342 \\ 193 & 0 & 214 \\ 940 & 65 & 526 \\ 81 & 0 & 212 \\ 452 & 27 & 365 \\ 56 & 0 & 38 \\ 70 & 0 & 125 \\ 102 & 8 & 227 \\ 238 & 0 & 244 \\ 1.072 & 300 & 643 \\ 1.792 & 60 & 1.434 \\ 292 & 43 & 148 \\ 636 & 33 & 1.035 \\ 1.453 & 88 & 1.391 \\ 617 & 0 & 177 \\ 396 & 23 & 708 \\ 382 & 12 & 705 \\ 324 & 45 & 1.077 \\ 22 & 4 & 38 \\ 290 & 33 & 261 \\ 323 & 83 & 962 \\ 192 & 15 & 100 \\ 4.069 & 433 & 4.142 \\ 419 & 140 & 359\end{array}$

$\begin{array}{rr}239 & 9 \\ 263 & 20 \\ 152 & 11 \\ 234 & 14 \\ 33 & 0 \\ 490 & 22 \\ 271 & 0 \\ 342 & 21 \\ 214 & 0 \\ 526 & 37 \\ 212 & 33 \\ 365 & 33 \\ 38 & 0 \\ 125 & 0 \\ 227 & 0 \\ 244 & 17 \\ 643 & 21 \\ 434 & 90 \\ 148 & 47 \\ .035 & 0 \\ .391 & 30 \\ 177 & 0 \\ 708 & 8 \\ 705 & 41 \\ .077 & 0 \\ 38 & 0 \\ 261 & 6 \\ 962 & 0 \\ 100 & 0 \\ .142 & 127 \\ 359 & 20 \\ & \end{array}$

$\begin{array}{rr}0 & 356 \\ 0 & 496 \\ 7 & 233 \\ 1 & 494 \\ 0 & 40 \\ 0 & 1.401 \\ 0 & 541 \\ 21 & 1.114 \\ 0 & 406 \\ 10 & 1.588 \\ 6 & 360 \\ 21 & 898 \\ 0 & 94 \\ 0 & 217 \\ 0 & 346 \\ 0 & 499 \\ 23 & 2.146 \\ 0 & 3.375 \\ 0 & 529 \\ 1 & 1.725 \\ 1 & 3.071 \\ 1 & 795 \\ 8 & 1.150 \\ 6 & 1.151 \\ 35 & 1.552 \\ 0 & 64 \\ 14 & 618 \\ 8 & 1.376 \\ 0 & 306 \\ 82 & 9.045 \\ 0 & 937\end{array}$


Tabel C.5 (vervolg)

Naar landelijke populatie gewogen aantal schoolverlaters verbijzonderd naar bestemming per opleidingsrichting

Opleidingsrichting studie BBL $\begin{array}{r}\text { betald werk } \\ \text { werk }\end{array}$

BBL niveau $1 / 2$

AB Groene ruimte

$A B$ Beveiliging

AB Detailhandel/ambulante handel

$A B$ Verpleging en verzorging

BB Plantenteelt

BB Bloemschikken

BB Groene ruimte

BB Bouw

BB Houtbewerking en woninginrichting

BB Grond-, water en wegenbouw

BB Beschermings- en afwerkingstechnieken

BB Constructie-, plaatwerken/pijpenbewerken

BB Montage/onderhoud/operationele techniek

BB Motorvoertuigen

BB Energie- en informatietechniek

BB Installatie-, service- en onderhoudstechniek

BB Wegvervoer

BB Detailhandel/ambulante handel

BB Opslag/magazijn

BB Horeca, instellingskeuken en contractcatering

BB Facilitaire dienstverlenin

$B B$ Verpleging en verzorging

BB Uiterlijke verzorging

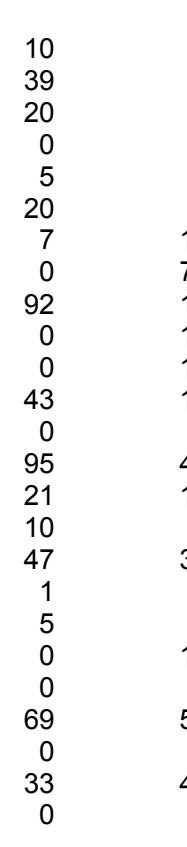

$\begin{array}{rr}43 & 255 \\ 0 & 1.010 \\ 58 & 201 \\ 25 & 64 \\ 38 & 157 \\ 86 & 208 \\ 137 & 443 \\ 780 & 1.613 \\ 108 & 524 \\ 174 & 348 \\ 120 & 360 \\ 157 & 463 \\ 31 & 86 \\ 474 & 822 \\ 106 & 213 \\ 92 & 234 \\ 394 & 464 \\ 0 & 231 \\ 0 & 586 \\ 151 & 1.214 \\ 38 & 283 \\ 543 & 762 \\ 8 & 139 \\ 442 & 1.285 \\ 0 & 614\end{array}$

10
39
31
0
4
12
0
66
30
87
0
13
0
0
0
20
26
11
0
49
28
0
0
16
0

ZB Plantenteelt

ZB Groene ruim

$\begin{array}{rrr}14 & 0 & 96 \\ 7 & 10 & 217 \\ 30 & 17 & 275\end{array}$

96
217
275
1145

ZB Bouw

0
3
0
0

$\begin{array}{rrr}0 & 16 & 334 \\ 0 & 0 & 1.088 \\ 10 & 0 & 320 \\ 10 & 0 & 98 \\ 5 & 5 & 213 \\ 0 & 0 & 326 \\ 0 & 15 & 602 \\ 66 & 73 & 2.597 \\ 0 & 0 & 754 \\ 0 & 0 & 609 \\ 0 & 0 & 480 \\ 13 & 0 & 690 \\ 0 & 0 & 117 \\ 32 & 0 & 1.423 \\ 0 & 0 & 340 \\ 0 & 10 & 366 \\ 0 & 26 & 957 \\ 0 & 0 & 243 \\ 0 & 0 & 591 \\ 54 & 0 & 1.467 \\ 0 & 0 & 349 \\ 24 & 0 & 1.398 \\ 8 & 0 & 154 \\ 48 & 16 & 1.839 \\ 0 & 0 & 614\end{array}$


Tabel C.5 (vervolg)

Naar landelijke populatie gewogen aantal schoolverlaters verbijzonderd naar bestemming per opleidingsrichting

Opleidingsrichting studie BBL betald werkloos anders onbekend totaal

BBL niveau 3/4 (vervolg)

ZB Grond-, water- en wegenbouw

ZB Constructie- plaatwerken/pijpenbewerken

ZB Motorvoertuigen

ZB Energie- en informatietechniek

ZB Beheer, ontwerp en management (instal. techn)

ZB Installatie-, service- en onderhoudstechniek

ZB Procestechniek

ZB Automatisering

ZB Detailhandel/ambulante handel

ZB Opslag/magazijn

ZB Horeca, instellingskeuken en contractcatering

ZB Verpleging en verzorging

ZB Uiterlijke verzorging

MKF Bouw

MKF Detailhandel/ambulante handel

MKF Horeca, instellingskeuken en contractcatering

MKF Verpleging en verzorging

MKF Sociaal-pedagogisch werk

Specialist Energietechniek

Specialist Verpleging en verzorging

$\begin{array}{rr}0 & 23 \\ 14 & 7 \\ 0 & 16 \\ 0 & 7 \\ 49 & 72 \\ 0 & 7 \\ 0 & 191 \\ 0 & 16 \\ 22 & 0 \\ 15 & 47 \\ 11 & 0 \\ 24 & 24 \\ 17 & 351 \\ 32 & 0 \\ 8 & 8 \\ 45 & 23 \\ 1 & 3 \\ 32 & 66 \\ 3 & 0 \\ 10 & 0 \\ 0 & 0\end{array}$

\begin{tabular}{rrrrr}
374 & 11 & 23 & 0 & 431 \\
190 & 7 & 0 & 7 & 226 \\
289 & 0 & 0 & 0 & 305 \\
109 & 0 & 1 & 0 & 117 \\
345 & 0 & 0 & 0 & 467 \\
119 & 0 & 0 & 0 & 126 \\
896 & 0 & 14 & 0 & 1.100 \\
338 & 16 & 0 & 0 & 370 \\
122 & 14 & 0 & 7 & 165 \\
785 & 47 & 16 & 15 & 925 \\
153 & 11 & 0 & 0 & 175 \\
1.047 & 0 & 24 & 0 & 1.118 \\
3.381 & 0 & 157 & 17 & 3.924 \\
705 & 0 & 17 & 0 & 755 \\
101 & 0 & 8 & 8 & 132 \\
298 & 0 & 0 & 0 & 366 \\
16 & 0 & 1 & 1 & 23 \\
2.108 & 0 & 0 & 0 & 2.306 \\
459 & 7 & 5 & 0 & 474 \\
228 & 2 & 0 & 0 & 240 \\
98 & 0 & 0 & 0 & 98 \\
& & 0 & & \\
\hline
\end{tabular}


Tabel C.6

Responspercentage per opleidingsrichting

Opleidingsrichting

VBO

IVBO Landbouw en natuurlijke omgeving

IVBO Bouwtechniek

IVBO Mechanische techniek $\quad 29$

IVBO Consumptieve techniek $\quad 45$

IVBO Verkoop $\quad 50$

IVBO Verzorging $\quad 55$

IVBO Uiterlijke verzorging $\quad 100$

IVBO Algemene voorbereiding op maatschappij en beroep (AVMB) 33

Landbouw en natuurlijke omgeving $\quad 59$

Techniek 14

$\begin{array}{ll}\text { Bouwtechniek } & 48\end{array}$

Mechanische techniek $\quad 54$

$\begin{array}{ll}\text { Elektrotechniek } & 41\end{array}$

$\begin{array}{ll}\text { Installatietechniek } & 56\end{array}$

$\begin{array}{ll}\text { Motorvoertuigentechniek } & 40\end{array}$

Consumptieve techniek $\quad 44$

Grafische techniek $\quad 58$

$\begin{array}{ll}\text { Nautische opleidingen } & 58\end{array}$

$\begin{array}{lr}\text { Administratie } & 43\end{array}$

Verkoop $\quad 48$

$\begin{array}{ll}\text { Handel } & 25 \\ \text { Verosging } & 25\end{array}$

Verzorging $\quad 62$

Uiterlijke verzorging $\quad 54$

$\begin{array}{ll}\text { Mode en kleding } & 39\end{array}$

$\begin{array}{ll}\text { VMBO Techniek } & 47\end{array}$

VMBO Zorg en Welzijn $\quad 82$

BOL niveau $1 / 2$

$\begin{array}{ll}\text { AB Plantenteelt } & 20 \\ \text { AB BouW } & 35\end{array}$

AB Bouw $\quad 35$

AB Constructie-, plaatwerken/pijpenbewerken $\quad 14$

AB Lassen $\quad 5$

AB Machinebankwerken/verspanen 31

AB Motorvoertuigen $\quad 33$

AB Energietechniek 11

AB Installatie-, service- en onderhoudstechniek $\quad 100$

AB Graf. techn, communicatie, audiovisueel en multimedia $\quad 80$

$A B$ Beveiliging $\quad 38$

$A B$ Secretarieel $\quad 36$

AB Detailhandel/ambulante handel $\quad 21$

AB Groothandel/distributie $\quad 20$

AB Horeca, instellingskeuken en contractcatering $\quad 28$

$A B$ Verpleging en verzorging $\quad 43$

$\begin{array}{ll}\text { BB Plantenteelt } & 35\end{array}$

BB Veehouderij $\quad 24$

BB Levensmiddelentechnologie $\quad 33$

BB Bloemschikken $\quad 37$

BB Dierverzorging en veterinaire ondersteuning 29

BB Paardenhouderij en paardensport $\quad 46$

BB Groene ruimte $\quad 25$

$\begin{array}{ll}\text { BB Bouw } & 39\end{array}$

BB Houtbewerking en woninginrichting $\quad 40$

BB Beschermings- en afwerkingstechnieken $\quad 35$

BB Reclame, presentatie en communicatie $\quad 35$

BB Constructie-, plaatwerken/pijpenbewerken 33

$\begin{array}{ll}\text { BB Montage/onderhoud/operationele techniek } & 50\end{array}$

$\begin{array}{ll}\text { BB Operationele techniek } & 40\end{array}$

BB Motorvoertuigen $\quad 30$ 
Tabel C.6 (vervolg)

Responspercentage per opleidingsrichting

Opleidingsrichting

BOL niveau $1 / 2$ (vervolg)

$\begin{array}{ll}\text { BB Energie- en informatietechniek } & 40\end{array}$

$\begin{array}{ll}\text { BB Energietechniek } & 39\end{array}$

BB Informatietechniek 22

BB Installatie-, service- en onderhoudstechniek $\quad 25$

BB Graf. techn, communicatie, audiovisueel en multimedia 38

BB Mode en kleding (realisatie) $\quad 33$

BB Procestechniek $\quad 50$

BB Haven en vervoer $\quad 20$

33

BB Brood- en banketbakken algemeen

BB Bedrijfsadministratie $\quad 35$

BB Beveiliging $\quad 41$

BB Commercieel $\quad 29$

BB Secretarieel $\quad 29$

BB Detailhandel/ambulante handel $\quad 25$

BB Horeca, instellingskeuken en contractcatering 44

BB Toerisme, recreatie en reizen $\quad 18$

BB Facilitaire dienstverlening $\quad 36$

$\begin{array}{ll}\text { BB Verpleging en verzorging } & 37\end{array}$

BB Uiterlijke verzorging $\quad 55$

BOL niveau 3/4

ZB Plantent

ZB Veehouderi

ZB Vevensmiddelentechnologie $\quad 43$

ZB Bloemschikken $\quad 44$

ZB Dierverzorging en veterinaire ondersteuning 45

ZB Paardenhouderij en paardensport $\quad 44$

ZB Groene ruimte $\quad 40$

ZB Houtbewerking en woninginrichting $\quad 27$

ZB Werktuigbouwkunde $\quad 56$

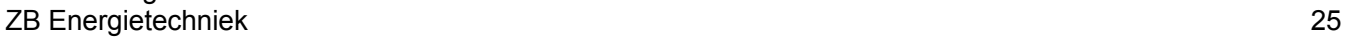

ZB Graf. techn, communicatie, audiovisueel en multimedia 41

ZB Laboratoriumtechniek $\quad 33$

ZB Haven en vervoer $\quad 50$

ZB Scheepvaart $\quad 39$

$\begin{array}{lr}\text { ZB Automatisering } & 29\end{array}$

ZB Bedrijfsadministratief $\quad 43$

ZB Commercieel $\quad 32$

ZB Logistiek $\quad 75$

ZB Secretarieel $\quad 23$

ZB Detailhandel/ambulante handel $\quad 34$

ZB Groothandel/distributie $\quad 52$

ZB Toerisme, recreatie en reizen $\quad 32$

ZB Verpleging en verzorging $\quad 57$

ZB Uiterlijke verzorging $\quad 46$

$\begin{array}{ll}\text { ZB Maatschappelijke dienstverlening } & 60\end{array}$

ZB Sociaal pedagogisch werk $\quad 40$

KF Plantenteelt $\quad 50$

KF Veehouderij $\quad 53$

KF Levensmiddelentechnologie $\quad 52$

KF Bloemschikken $\quad 58$

KF Dierverzorging en veterinaire ondersteuning $\quad 50$

KF Paardenhouderij en paardensport $\quad 35$

KF Groene ruimte $\quad 53$

KF Milieutoezicht $\quad 46$

$\begin{array}{ll}\text { MKF Bouw } & 50\end{array}$

MKF Houtbewerking en woninginrichting $\quad 49$

MKF Grond-, water- en wegenbouw $\quad 40$ 
Tabel C.6 (vervolg)

Responspercentage per opleidingsrichting

Opleidingsrichting

BOL niveau 3/4 (vervolg)

MKF Beschermings- en afwerkingstechnieken $\quad 43$

MKF Reclame, presentatie en communicatie $\quad 50$

$\begin{array}{ll}\text { MKF Fijnmechanische techniek } & 48\end{array}$

$\begin{array}{ll}\text { MKF Meet- en regeltechniek } & 70\end{array}$

MKF Operationele techniek $\quad 43$

$\begin{array}{ll}\text { MKF Werktuigbouwkunde } & 38\end{array}$

MKF Motorvoertuigen $\quad 48$

MKF Motorvoertuigen en carrosserietechniek $r$

MKF Energie- en informatietechniek $\quad 50$

MKF Energietechniek $\quad 31$

MKF Informatietechniek $\quad 42$

MKF Scheepsbouwkunde $\quad 67$

MKF Fijne techniek $\quad 50$

MKF Graf. techn, communicatie, audiovisueel en multimedi $\quad 44$

MKF Mode en kleding (realisatie)

$\begin{array}{ll}\text { MKF Laboratoriumtechniek } & 49\end{array}$

$\begin{array}{ll}\text { MKF Milieutechniek } & 64\end{array}$

MKF Procestechniek $\quad 50$

$\begin{array}{ll}\text { MKF Haven en vervoer } & 48\end{array}$

$\begin{array}{ll}\text { MKF Scheepvaart } & 47\end{array}$

$\begin{array}{ll}\text { MKF Transport en logistiek } & 41\end{array}$

MKF Automatisering $\quad 33$

MKF Bedrijfsadministratief $\quad 48$

$\begin{array}{ll}\text { MKF Commercieel } & 44\end{array}$

MKF Economisch-juridisch $\quad 53$

$\begin{array}{ll}\text { MKF Logistiek } & 29\end{array}$

MKF Secretarieel $\quad 52$

MKF Detailhandel/ambulante handel $\quad 37$

$\begin{array}{lr}\text { MKF Groothandel/distributie } & 40\end{array}$

MKF Opslag/magazijn $\quad 100$

MKF Textielhandel $r$

MKF Horeca, instellingskeuken en contractcatering $\quad 39$

MKF Toerisme, recreatie en reizen $\quad 41$

$\begin{array}{ll}\text { MKF Assistenten gezondheidszorg } & 59\end{array}$

MKF Facilitaire dienstverlening $\quad 64$

MKF Sport en bewegen $\quad 46$

MKF Verpleging en verzorging $\quad 65$

MKF Maatschappelijke dienstverlening $\quad 62$

$\begin{array}{ll}\text { MKF Sociaal-cultureel werker } & 40\end{array}$

MKF Sociaal-pedagogisch werk algemeen $\quad 58$

$\begin{array}{ll}\text { MKF Sociaal-juridisch werk } & 42\end{array}$

$\begin{array}{lr}\text { Specialist Automatisering } & 18\end{array}$

BBL niveau $1 / 2$

AB Plantenteelt

$A B$ Groene ruimte

AB Bouw

$A B$ Houtbewerking en woninginrichting

33
6

AB Constructie-, plaatwerken/pijpenbewerken $\quad 21$

AB Lassen $\quad 16$

AB Machinebankwerken/verspanen $\quad 50$

AB Montage/onderhoud/operationele techniek 40

$\begin{array}{ll}A B \text { Motorvoertuigen } & 16\end{array}$

AB Installatie-, service- en onderhoudstechniek

$\begin{array}{ll}A B \text { Fijne techniek } & 25\end{array}$

AB Graf. techn, communicatie, audiovisueel en multimedia $\quad 56$

$\begin{array}{ll}\text { AB Textieltechniek } & 17\end{array}$

AB Procestechniek 13 
Tabel C.6 (vervolg)

Responspercentage per opleidingsrichting

Opleidingsrichting

BBL niveau $1 / 2$ (vervolg)

AB Haven en vervoer

AB Brood- en banketbakken

AB Beveiliging $\quad 23$

AB Secretarieel $\quad 25$

AB Detailhandel/ambulante handel 33

AB Opslag/magazijn $\quad 50$

AB Horeca, instellingskeuken en contractcatering $\quad 38$

$A B$ Verpleging en verzorging $\quad 43$

BB Plantenteelt $\quad 33$

BB Veehouderij $\quad 17$

BB Levensmiddelentechnologie $\quad 13$

$\begin{array}{ll}\text { BB Bloemschikken } & 39\end{array}$

BB Dierverzorging en veterinaire ondersteuning 33

BB Biologisch-dynamische land- en tuinbouw $\quad 20$

BB Paardenhouderij en paardensport 22

BB Groene ruimte $\quad 29$

BB Bouw $\quad 32$

BB Houtbewerking en woninginrichting

BB Grond-, water en wegenbouw $\quad 21$

BB Beschermings- en afwerkingstechnieken $\quad 28$

BB Industriele lakverwerking $\quad 38$

BB Constructie-, plaatwerken/pijpenbewerken 36

BB Lassen $\quad 63$

$\begin{array}{ll}\text { BB Machinebankwerken/verspanen } & 29\end{array}$

BB Meet- en regeltechniek $\quad 43$

BB Montage/onderhoud/operationele techniek $\quad 38$

BB Scheepsbouw (metaal) $r$

BB Carrosserie en wagenbouw 24

28

BB Energie- en informatietechniek

BB Energietechniek $\quad 36$

BB Informatietechniek $\quad 25$

BB Distributietechniek $\quad 20$

$\begin{array}{ll}\text { BB Installatie-, service- en onderhoudstechniek } & 30\end{array}$

BB Fijne techniek $\quad 42$

BB Pianotechniek $\quad 50$

BB Graf. techn, communicatie, audiovisueel en multimedia $\quad 57$

BB Mode en kleding (realisatie) $\quad 67$

BB Textieltechniek $\quad 52$

BB Procestechniek

BB Wegvervoer $\quad 45$

BB Brood- en banketbakken $\quad 29$

$\begin{array}{ll}\text { BB Bedrijfsadministratief } & 45\end{array}$

$\begin{array}{ll}\text { BB Commercieel } & 50\end{array}$

BB Secretarieel $\quad 43$

BB Detailhandel/ambulante handel $\quad 44$

BB Opslag/magazijn $\quad 27$

BB Horeca, instellingskeuken en contractcatering 36

BB Toerisme, recreatie en reizen $\quad 46$

BB Facilitaire dienstverlening $\quad 43$

$\begin{array}{ll}\text { BB Verpleging en verzorging } & 35\end{array}$

$\begin{array}{ll}\text { BB Uiterlijke verzorging } & 27\end{array}$

BBL niveau $3 / 4$

ZB Plantenteelt

$\begin{array}{ll}\text { ZB Levensmiddelentechnologie } & 67 \\ & 20\end{array}$

ZB Bloemschikken $\quad 49$

ZB Dierverzorging en veterinaire ondersteuning $\quad 55$ 
Tabel C.6 (vervolg)

Responspercentage per opleidingsrichting

Opleidingsrichting

BBL niveau 3/4 (vervolg)

ZB Paardenhouderij en paardensport $\quad 30$

ZB Groene ruimte $\quad 41$

ZB Bouw

ZB Houtbewerking en woninginrichting $\quad 30$

ZB Grond-, water- en wegenbouw

ZB Beschermings- en afwerkingstechnieken $\quad 33$

ZB Industriële lakverwerking 31

ZB Constructie-, plaatwerken/pijpenbewerken $\quad 45$

40

ZB Montage/onderhoud/operationele techniek

ZB Vliegtuigtechnieken $\quad 50$

ZB Wertuigbouwkunde $\quad 100$

ZB Carrosserie en wagenbouw $\quad 41$

28

ZB Energie- en informatietechniek $\quad 35$

ZB Energietechniek $\quad 38$

ZB Beheer, ontwerp en management (instal. techn) $\quad 45$

ZB Distributietechniek 22

ZB Installatie-, service- en onderhoudstechniek $\quad 32$

ZB Fijne techniek

ZB Graf. techn, communicatie, audiovisueel en multimedia 40

ZB Procestechniek

ZB Wegvervoer

ZB Brood- en banketbakken $\quad 33$

ZB Automatisering $\quad 40$

ZB Bedrijfsadministratief $\quad 38$

ZB Commercieel $\quad 25$

ZB Logistiek $\quad 100$

ZB Secretarieel $\quad 28$

ZB Detailhandel/ambulante handel 38

ZB Opslag/magazijn $\quad 23$

ZB Horeca, instellingskeuken en contractcatering 33

ZB Verpleging en verzorging $\quad 49$

ZB Uiterlijke verzorging $\quad 32$

ZB Sociaal-pedagogisch werk $\quad 65$

$\begin{array}{ll}\text { KF Plantenteelt } & 44\end{array}$

$\begin{array}{lr}\text { KF Veehouderij } & 40\end{array}$

KF Bloemschikken $\quad 43$

$\begin{array}{ll}\text { KF Paardenhouderij en paardensport } & 67\end{array}$

KF Groene ruimte $\quad 40$

$\begin{array}{ll}\text { MKF Bouw } & 44\end{array}$

$\begin{array}{lr}\text { MKF Automatisering } & 29\end{array}$

MKF Logistiek $\quad 24$

$\begin{array}{ll}\text { MKF Secretarieel } & 33\end{array}$

MKF Detailhandel/ambulante handel $\quad 27$

MKF Opslag/magazijn $\quad 50$

MKF Horeca, instellingskeuken en contractcatering $\quad 42$

MKF Verpleging en verzorging $\quad 46$

MKF Sociaal-pedagogisch werk $\quad 52$

Specialist Werktuigbouwkunde $\quad 50$

$\begin{array}{ll}\text { Specialist Motorvoertuigen } & 20\end{array}$

Specialist Energie- en informatietechniek $\quad 22$

Specialist Energietechniek $\quad 39$

$\begin{array}{ll}\text { Specialist Informatietechniek } & 25\end{array}$

Specialist Installatie-, service- en onderhoudstechniek 25

Specialist Graf. techn, communicatie, audiovisueel en mu $\quad 44$

Specialist Procestechniek $\quad 36$

$\begin{array}{lr}\text { Specialist Brood- en banketbakken } & 100\end{array}$

$\begin{array}{lr}\text { Specialist Automatisering } & 35\end{array}$ 
Tabel C. 6 (vervolg)

Responspercentage per opleidingsrichting

Opleidingsrichting

BBL niveau 3/4 (vervolg)

Specialist Verpleging en verzorging

48

In-service Verpleegkundige A

67 

D. Opleidingsindeling 



\section{Overzicht van opleidingen per opleidingssector}

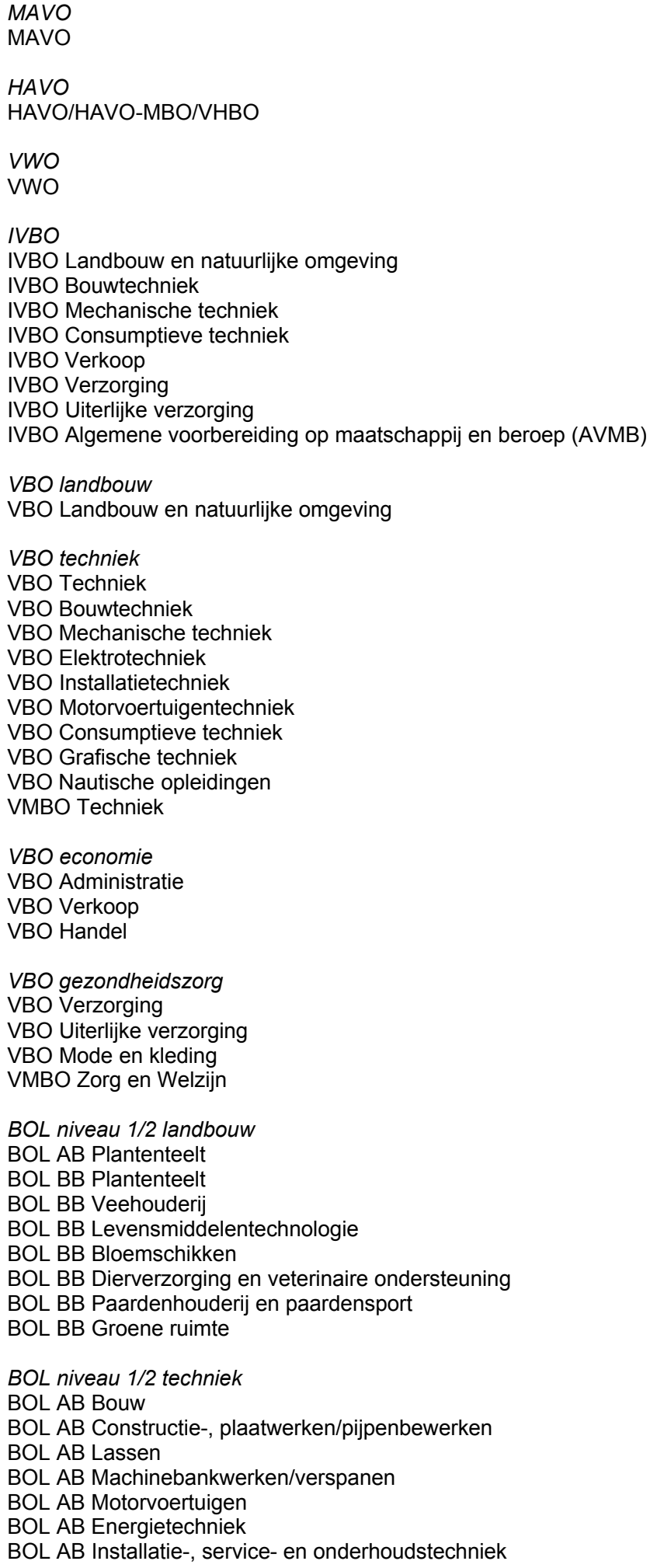


BOL AB Graf. techn, communicatie, audiovisueel en multimedia

BOL BB Bouw

BOL BB Houtbewerking en woninginrichting

BOL BB Beschermings- en afwerkingstechnieken

BOL BB Reclame, presentatie en communicatie

BOL BB Constructie-, plaatwerken/pijpenbewerken

BOL BB Montage/onderhoud/operationele techniek

BOL BB Operationele techniek

BOL BB Motorvoertuigen

BOL BB Energie- en informatietechniek

BOL BB Energietechniek

BOL BB Informatietechniek

BOL BB Installatie-, service- en onderhoudstechniek

BOL BB Graf. techn, communicatie, audiovisueel en multimedia

BOL BB Mode en kleding (realisatie)

BOL BB Procestechniek

BOL BB Haven en vervoer

BOL BB Scheepvaart

BOL BB Brood- en banketbakken algemeen

$B O L$ niveau $1 / 2$ economie

BOL AB Beveiliging

BOL AB Secretariee

BOL AB Detailhandel/ambulante handel

BOL AB Groothandel/distributie

$B O L A B$ Horeca, instellingskeuken en contractcatering

BOL BB Bedrijfsadministratie

BOL BB Beveiliging

BOL BB Commercieel

BOL BB Secretarieel

BOL BB Detailhandel/ambulante handel

BOL BB Horeca, instellingskeuken en contractcatering

BOL BB Toerisme, recreatie en reizen

$B O L$ niveau $1 / 2$ gezondheidszorg

$B O L A B$ Verpleging en verzorging

BOL BB Facilitaire dienstverlening

BOL BB Verpleging en verzorging

BOL BB Uiterlijke verzorging

$B O L$ niveau 3/4 landbouw

BOL ZB Plantenteelt

BOL ZB Veehouderij

BOL ZB Levensmiddelentechnologie

BOL ZB Bloemschikken

BOL ZB Dierverzorging en veterinaire ondersteuning

BOL ZB Paardenhouderij en paardensport

BOL ZB Groene ruimte

BOL KF Plantenteelt

BOL KF Veehouderij

BOL KF Levensmiddelentechnologie

BOL KF Bloemschikken

BOL KF Dierverzorging en veterinaire ondersteuning

BOL KF Paardenhouderij en paardensport

BOL KF Groene ruimte

BOL KF Milieutoezicht

BOL niveau 3/4 techniek

BOL ZB Houtbewerking en woninginrichting

BOL ZB Werktuigbouwkunde

BOL ZB Energietechniek

BOL ZB Graf. techn, communicatie, audiovisueel en multimedia

BOL ZB Laboratoriumtechniek

BOL ZB Haven en vervoer

BOL ZB Scheepvaart

BOL MKF Bouw

BOL MKF Houtbewerking en woninginrichting 
BOL MKF Grond-, water- en wegenbouw

BOL MKF Beschermings- en afwerkingstechnieken

BOL MKF Reclame, presentatie en communicatie

BOL MKF Fijnmechanische techniek

BOL MKF Meet- en regeltechniek

BOL MKF Operationele techniek

BOL MKF Werktuigbouwkunde

BOL MKF Motorvoertuigen

BOL MKF Motorvoertuigen en carrosserietechniek

BOL MKF Energie- en informatietechniek

BOL MKF Energietechniek

BOL MKF Informatietechniek

BOL MKF Scheepsbouwkunde

BOL MKF Fijne techniek

BOL MKF Graf. techn, communicatie, audiovisueel en multimedi

BOL MKF Mode en kleding (realisatie)

BOL MKF Laboratoriumtechniek

BOL MKF Milieutechniek

BOL MKF Procestechniek

BOL MKF Haven en vervoer

BOL MKF Scheepvaart

BOL MKF Transport en logistiek

$B O L$ niveau $3 / 4$ economie

$\mathrm{BOL}$ ZB Automatisering

BOL ZB Bedrijfsadministratief

BOL ZB Commercieel

BOL ZB Logistiek

BOL ZB Secretarieel

BOL ZB Detailhandel/ambulante handel

BOL ZB Groothandel/distributie

BOL ZB Toerisme, recreatie en reizen

BOL MKF Automatisering

BOL MKF Bedrijfsadministratief

BOL MKF Commercieel

BOL MKF Economisch-juridisch

BOL MKF Logistiek

BOL MKF Secretarieel

BOL MKF Detailhandel/ambulante handel

BOL MKF Groothandel/distributie

BOL MKF Opslag/magazijn

BOL MKF Textielhandel

BOL MKF Horeca, instellingskeuken en contractcatering

BOL MKF Toerisme, recreatie en reizen

BOL Specialist Automatisering

$B O L$ niveau $3 / 4$ gezondheidszorg

BOL ZB Verpleging en verzorging

BOL ZB Uiterlijke verzorging

BOL MKF Assistenten gezondheidszorg

BOL MKF Facilitaire dienstverlening

BOL MKF Sport en bewegen

BOL MKF Verpleging en verzorging

BOL niveau $3 / 4$ gedrag en maatschappij

BOL ZB Maatschappelijke dienstverlening

BOL ZB Sociaal pedagogisch werk

BOL MKF Maatschappelijke dienstverlening

BOL MKF Sociaal-cultureel werker

BOL MKF Sociaal-pedagogisch werk algemeen

BOL MKF Sociaal-juridisch werk

$B B L$ niveau 1/2 landbouw

BBL AB Plantenteelt

BBL AB Groene ruimte

BBL BB Plantenteelt

BBL BB Veehouderij 
BBL BB Levensmiddelentechnologie

BBL BB Bloemschikken

BBL BB Dierverzorging en veterinaire ondersteuning

BBL BB Biologisch-dynamische land- en tuinbouw

BBL BB Paardenhouderij en paardensport

BBL BB Groene ruimte

BBL niveau 1/2 techniek

BBL AB Bouw

$B B L A B$ Houtbewerking en woninginrichting

$B B L A B$ Industriële lakverwerking

BBL AB Constructie-, plaatwerken/pijpenbewerken

BBL AB Lassen

BBL AB Machinebankwerken/verspanen

BBL AB Montage/onderhoud/operationele techniek

BBL AB Motorvoertuigen

BBL AB Installatie-, service- en onderhoudstechniek

BBL AB Fijne techniek

BBL AB Graf. techn, communicatie, audiovisueel en multimedia

BBL AB Textieltechniek

BBL AB Procestechniek

$B B L A B$ Haven en vervoer

BBL AB Brood- en banketbakken

BBL BB Bouw

BBL BB Houtbewerking en woninginrichting

BBL BB Grond-, water en wegenbouw

BBL BB Beschermings- en afwerkingstechnieken

BBL BB Industriele lakverwerking

BBL BB Constructie-, plaatwerken/pijpenbewerken

BBL BB Lassen

BBL BB Machinebankwerken/verspanen

BBL BB Meet- en regeltechniek

BBL BB Montage/onderhoud/operationele techniek

BBL BB Scheepsbouw (metaal)

BBL BB Carrosserie en wagenbouw

BBL BB Motorvoertuigen

BBL BB Energie- en informatietechniek

BBL BB Energietechniek

BBL BB Informatietechniek

BBL BB Distributietechniek

BBL BB Installatie-, service- en onderhoudstechniek

BBL BB Fijne techniek

BBL BB Pianotechniek

BBL BB Graf. techn, communicatie, audiovisueel en multimedia

BBL BB Mode en kleding (realisatie)

BBL BB Textieltechniek

BBL BB Procestechniek

BBL BB Wegvervoer

BBL BB Brood- en banketbakken

$B B L$ niveau $1 / 2$ economie

BBL AB Beveiliging

BBL AB Secretariee

BBL AB Detailhandel/ambulante handel

BBL AB Opslag/magazijn

$B B L A B$ Horeca, instellingskeuken en contractcatering

BBL BB Bedrijfsadministratief

BBL BB Commercieel

BBL BB Secretarieel

BBL BB Detailhandel/ambulante handel

BBL BB Opslag/magazijn

BBL BB Horeca, instellingskeuken en contractcatering

BBL BB Toerisme, recreatie en reizen

$B B L$ niveau $1 / 2$ gezondheidszorg

$B B L A B$ Verpleging en verzorging

BBL BB Facilitaire dienstverlening 
BBL BB Verpleging en verzorging

BBL BB Uiterlijke verzorging

BBL niveau $3 / 4$ landbouw

BBL ZB Plantenteelt

BBL ZB Veehouderij

BBL ZB Levensmiddelentechnologie

BBL ZB Bloemschikken

$B B L Z B$ Dierverzorging en veterinaire ondersteuning

BBL ZB Paardenhouderij en paardensport

BBL ZB Groene ruimte

BBL KF Plantenteelt

BBL KF Veehouderij

BBL KF Bloemschikken

BBL KF Paardenhouderij en paardensport

BBL KF Groene ruimte

BBL niveau 3/4 techniek

BBL ZB Bouw

BBL ZB Houtbewerking en woninginrichting

BBL ZB Grond-, water- en wegenbouw

BBL ZB Beschermings- en afwerkingstechnieken

$\mathrm{BBL} Z \mathrm{ZB}$ Industriële lakverwerking

BBL ZB Constructie-, plaatwerken/pijpenbewerken

BBL ZB Machinebankwerken/verspanen

BBL ZB Montage/onderhoud/operationele techniek

BBL ZB Vliegtuigtechnieken

BBL ZB Wertuigbouwkunde

BBL ZB Carrosserie en wagenbouw

BBL ZB Motorvoertuigen

BBL ZB Energie- en informatietechniek

BBL ZB Energietechniek

BBL ZB Beheer, ontwerp en management (instal. techn)

BBL ZB Distributietechniek

BBL ZB Installatie-, service- en onderhoudstechniek

BBL ZB Fijne techniek

BBL ZB Graf. techn, communicatie, audiovisueel en multimedia

BBL ZB Procestechniek

BBL ZB Wegvervoer

BBL ZB Brood- en banketbakken

BBL MKF Bouw

BBL Specialist Werktuigbouwkunde

BBL Specialist Motorvoertuigen

BBL Specialist Energie- en informatietechniek

BBL Specialist Energietechniek

BBL Specialist Informatietechniek

BBL Specialist Installatie-, service- en onderhoudstechniek

BBL Specialist Graf. techn, communicatie, audiovisueel en mu

BBL Specialist Procestechniek

BBL Specialist Brood- en banketbakken

BBL niveau $3 / 4$ economie

BBL ZB Automatisering

BBL ZB Bedrijfsadministratief

BBL ZB Commercieel

BBL ZB Logistiek

BBL ZB Secretarieel

BBL ZB Detailhandel/ambulante handel

BBL ZB Opslag/magazijn

BBL ZB Horeca, instellingskeuken en contractcatering

BBL MKF Automatisering

BBL MKF Logistiek

BBL MKF Secretarieel

BBL MKF Detailhandel/ambulante handel

BBL MKF Opslag/magazijn

BBL MKF Horeca, instellingskeuken en contractcatering

BBL Specialist Automatisering 
$B B L$ niveau 3/4 gezondheidszorg

$B B L$ ZB Verpleging en verzorging

BBL ZB Uiterlijke verzorging

$B B L$ MKF Verpleging en verzorging

BBL Specialist Verpleging en verzorging

In-service Verpleegkundige A

BBL niveau 3/4 gedrag en maatschappij

BBL ZB Sociaal-pedagogisch werk

BBL MKF Sociaal-pedagogisch werk

HBO landbouw

HBO Landbouw/produktie

HBO Landbouw/bedrijfskunde

HBO Milieu/groene ruimte

HBO Technologie/laboratorium

HBO Agrarische docentopl.

HBO Plattelandsvernieuwing

$H B O$ onderwijs

HBO Leraar basis-/speciaalonderwijs

HBO Leraar VO taal 1-vak (2e gr.)

HBO Leraar VO maatschappij 1-vak (2e gr.)

HBO Leraar VO expressie 1-vak (2e gr.)

HBO Leraar techniek VO 1-vak (2e gr.)

HBO Leraar VO lichamelijke oefening (1e gr.)

HBO Leraar VO exact 1-vak (1e/2e gr.)

HBO Algemene beroepenvariant Hogere kaderopleiding pedagogie

HBO techniek

HBO Kort Logistiek

HBO Kort Bedrijfskaderopleiding

HBO Bouwkunde

HBO Civiele techniek

HBO Geodesie

HBO Verkeerskunde

HBO Ruimtelijke ordening en planologie

HBO Milieukunde (technisch)

HBO Logistiek en technische vervoerskunde

HBO Elektrotechniek

HBO Computertechniek

HBO Hogere informatica

HBO Informatica en informatiekunde

HBO Werktuigbouwkunde

HBO Luchtvaarttechnologie

HBO Scheepsbouwkunde

HBO Technische natuurkunde

HBO Industrieel product ontwerpen

$\mathrm{HBO}$ Chemische technologie

HBO Aquatische ecotechnologie

HBO Milieugerichte materiaaltechnologie

HBO Milieutechnologie (technische)

HBO Wiskunde

HBO Biologie en medisch laboratoriumonderzoek

HBO Chemie

HBO Technische bedrijfskunde

HBO Bouwtechnische bedrijfskunde

HBO Algemene operationele technologie

HBO Maritiem officier

HBO Biologische laboratoriumopleiding

$\mathrm{HBO}$ Chemische laboratoriumopleiding

HBO Medische laboratoriumopleiding

HBO Laboratoriuminformatica en automatisering

HBO economie

HBO Kort Hoger toeristisch en recreatief onderwijs

HBO Accountancy 
HBO Bedrijfseconomie

HBO Fiscale economie

HBO Hoger onderwijs voor de financiele sector

HBO Bedrijfskundige informatica

HBO Bestuurskunde/overheidsmanagement

HBO Management, economie en recht

HBO Bedrijfswiskunde

HBO Commerciele economie

HBO Logistiek en economie

HBO Economisch-linguistische opleiding

HBO Small business en retail management

HBO Voeding en marketing

HBO Communicatie

HBO Communicatiesystemen

HBO Hogere Europese beroepenopleiding

HBO Journalistiek en voorlichting

HBO Opleiding tolk-vertaler

HBO Orientaalse talen en communicatie

HBO Informatiedienstverlening en -management

HBO Facilitaire dienstverlening

HBO Hoger hotelonderwijs

HBO Hoger toeristisch en recreatief onderwijs

HBO Vrijetijdskunde

HBO Duaal Accountancy

HBO Duaal Bedrijfseconomie

HBO Duaal Commerciele economie

HBO Duaal Logistiek en economie

HBO Duaal Communicatie

HBO gezondheidszorg

HBO Opleiding tot verpleegkundige

HBO Opl. verpleegkundige maatschappelijke gezondheidszorg

HBO Bewegingstechnologie

HBO Medisch beeldvormende/radiotherapeutische technieken

HBO Fysiotherapie

HBO Ergotherapie

HBO Logopedie

HBO Optometrie

HBO Voeding en dietetiek

HBO Antroposofische gezondheidszorg

HBO Opleiding mondhygienist

HBO Opleiding tot orthoptist

HBO Bewegingsagogie/psychomotorische therapie

HBO Opleiding podotherapie

HBO Sport en bewegen

HBO Oefentherapie Cesar/Mensendieck

HBO Duaal Opleiding tot verpleegkundige

HBO gedrag en maatschappij

HBO Creatieve therapie

HBO Culturele en maatschappelijke vorming

HBO Expressie door woord en gebaar

HBO Maatschappelijk werk en dienstverlening

HBO Personeel en arbeid

HBO Sociaal-juridische dienstverlening

HBO Sociaal pedagogische hulpverlening

HBO Hoger pedagogisch en sociaal-agogisch onderwijs

HBO Godsdienst-pastoraal werk

HBO Integrale Veiligheidszorg (IVZ)

HBO Duaal Sociaal pedagogische hulpverlening

HBO Alg. beroepenvar. Hog. kaderopleiding pedagogie (HSAO)

HBO taal en cultuur

HBO Taal en cultuur

HBO Beeldende kunst autonoom

HBO Beeldende kunst toegepast design

HBO Beeldende kunst audiovisueel 
HBO Beeldende kunst docerend

HBO Muziek uitvoerend algemeen

HBO Muziek docerend algemeen

HBO Theater uitvoerend

HBO Theater docerend

WO landbouw

WO Landinrichtingswetenschappen

WO Tropisch landgebruik

WO Plantenteeltwetenschappen

WO Tuinbouwplantenteelt

WO Plantenveredeling en gewasbescherming

WO Zootechniek

WO Bosbouw

WO Voeding en gezondheid

WO Bioprocestechnologie

WO Levensmiddelentechnologie

WO Landbouwtechniek

WO Economie van landbouw en milieu

WO Rurale ontwikkelingsstudies

WO Huishoud- en consumentenwetenschappen

WO Agrosysteemkunde

WO Bodem, water en atmosfeer

WO Biologie

WO Milieuhygiene

WO Moleculaire wetenschappen

WO onderwijs

WO Kort Univ. leraaropl. Duits

WO Kort univ. leraaropl. Engels

WO Kort Univ. leraaropl. Frans

WO Kort Univ. leraaropl. Grieks en Latijn (Klassieken)

WO Kort Univ. leraaropl. kunstgeschiedenis

WO Kort Univ. leraaropl. Nederlands

WO Kort Univ. leraaropl. Spaans

WO Kort Univ. leraaropl. aardrijkskunde

WO Kort Univ. leraaropl. algemene economie

WO Kort Univ. leraaropl. bijbelkennis\&cultuurgesch. v/h chri

WO Kort Univ. leraaropl. geschiedenis en staatsinrichting

WO Kort Univ. leraaropl. maatschappijleer

WO Kort Univ. leraaropl. biologie

WO Kort Univ. leraaropl. natuurkunde

WO Kort Univ. leraaropl. scheikunde

WO Kort Univ. leraaropl. wiskunde

WO techniek

WO Technische aardwetenschappen

WO Scheikundige technologie en bioprocestechnologie

WO Technische mechanica

WO Technische natuurkunde

WO Technische scheikunde

WO Technische wiskunde

WO Bedrijfsinformatietechnologie

WO Informatietechniek

WO Technische informatica

WO Elektrotechniek

WO Bouwkunde

WO Civiele techniek

WO Civiele technologie en management

WO Geodesie

WO Installatietechniek

WO Industrieel ontwerpen

WO Luchtvaart- en ruimtevaarttechniek

WO Maritieme techniek

WO Materiaalkunde

WO Werktuigbouwkunde

WO Werktuigkundige medische technologie 
WO Technische bedrijfskunde

WO Technische bestuurskunde

WO Techniek en maatschappij

WO Wijsbegeerte, wetenschap, technologie en samenleving

WO Informatica

WO economie

WO Economie

WO Fiscale economie

WO Japankunde

WO Actuariele wetenschappen

WO Econometrie

WO Operationele research en management

WO Econometrie en operationele research

WO Bedrijfskunde

WO Bedrijfswetenschappen

WO Technische bedrijfswetenschappen

WO Domeingerichte economie

WO Bedrijfswetenschappen

WO gezondheidszorg

WO Diergeneeskunde

WO Geneeskunde

WO Tandheelkunde

WO Beleid en management gezondheidszorg

WO Bewegingswetenschappen

WO Biomedische wetenschappen

WO Gezondheidswetenschappen

WO Beleid en beheer van de gezondheidszorg (BB)

WO Bewegingswetenschappen (BW)

WO Biologische gezondheidkunde (BGK)

WO Geestelijke gezondheidkunde (GGK)

WO Gezondheidsvoorlichting (GVO)

WO Gezondheidswetenschappen Arbeid en Gezondheidszorg

WO Medische biologie

WO Medische informatiekunde

WO Milieugezondheidkunde

WO gedrag en maatschappij

WO Psychologie

WO Sociaal-wetenschappelijke informatica

WO Technische cognitiewetenschap

WO Pedagogische wetenschappen

WO Onderwijskunde

WO Toegepaste onderwijskunde

WO Communicatiewetenschap

WO Toegepaste communicatiewetenschap

WO Algemene sociale wetenschappen

WO Culturele antropologie/Soc niet-Westerse samenlevingen

WO Sociaal-culturele wetenschappen

WO Sociologie

WO Vrijetijdswetenschappen

WO Sociale geografie en Planologie

WO Milieu-maatschappijwetenschapen

WO Arbeid en sociale zekerheid

WO Personeelwetenschappen

WO Recht, bestuur en management

WO Beleids- en organisatiewetenschappen

WO Beleidsgerichte milieukunde

WO Bestuurskunde

WO Politicologie

WO Planologie

WO Sociale geografie

WO Technische planologie

WO Demografie

WO Kunstmatige intelligentie 
WO taal en cultuur

WO Griekse en Latijnse talen en culturen

WO Latijnse taal- en letterkunde

WO Nederlandse taal- en letterkunde

WO Duitse taal- en letterkunde

WO Engelse taal- en letterkunde

WO Franse taal- en letterkunde

WO Italiaanse taal- en letterkunde

WO Keltische talen en cultuur

WO Portugese taal- en letterkunde

WO Romaanse talen en culturen

WO Scandinavische talen en hun letterkunde

WO Spaanse taal- en letterkunde

WO Talen en culturen van Latijns Amerika

WO Afrikaanse taalkunde

WO Arabische, Nieuwperzische en Turkse talen en culturen

WO Chinese talen en culturen

WO Talen en culturen van Zuidoost-Azie en Oceanie

WO Japanse taal en cultuur

WO Nieuwgriekse taal- en letterkunde

WO Semitische talen en culturen

WO Slavische talen en hun letterkunde

WO Vergelijkende Indo-Europese taalwetenschap

WO Taalwetenschap

WO Alfa-informatica

WO Algemene letteren

WO Algemene literatuurwetenschap

WO Algemene taalwetenschap

WO Letteren

WO Spraak- en taalpathologie

WO Vertaalwetenschap

WO Afrikanistiek

WO Amerikanistiek

WO Duitslandstudies

WO Europese studies

WO Mediterrane studies

WO Midden-Oosten studies

WO Oost-europese studies

WO Ruslandkunde

WO Bedrijfscommunicatie letteren

WO Boek- en informatiewetenschap

WO Communicatiekunde

WO Toegepaste taalkunde

WO Beleid en bestuur internationale organisaties

WO Culturele studies

WO Cultuur- en wetenschapsstudies

WO Film- en televisiewetenschappen

WO Kunst- en cultuurwetenschappen

WO Muziekwetenschap

WO Taal- en cultuurstudies

WO Theater-, film- en televisiewetenschappen

WO Vergelijkende kunstwetenschap: woord en beeld

WO Cultuurwetenschappen

WO Godgeleerdheid

WO Godsdienstwetenschappen

WO Levensbeschouwingen

WO Religie en levensbeschouwing

WO Religiestudies

WO Sociaal-wetenschappelijke studie van de godsdienst

WO Archeologie

WO Europese archeologie

WO Comm. en informatiewetenschappen

WO Geschiedenis

WO Kunstgeschiedenis en archeologie

WO Maatschappijgeschiedenis

WO Medievistiek

WO Oudheidkunde 
WO Wijsbegeerte

WO Wijsbegeerte van een bepaald wetenschapsgebied

WO recht en openbare orde

WO Nederlands recht

WO Nederlands recht, internationale/Europees rechtelijke opl

WO Notariele opleiding

WO Fiscaal-juridische opleiding

WO European Law school

WO Internationaal recht

WO Internationaal-juridische opleiding

WO Juridische bestuurswetenschappelijke opleiding

WO Juridisch-politiekwetenschappelijke opleiding

WO Internationaal en Europees recht

WO natuurwetenschappen

WO Medische biologie

WO Bedrijfs- en industriele statistiek

WO Wiskunde

WO Bedrijfsinformatiesystemen

WO Bedrijfswiskunde en informatica

WO Cognitieve kunstmatige intelligentie

WO Computational science

WO Kennistechnologie

WO Kunstmatige intelligentie

WO Technische informatica

WO Infortmatiekunde

WO Natuurkunde

WO Sterrrenkunde

WO Geochemie

WO Geofysica

WO Geologie

WO Meteorologie en fysische oceanografie

WO Fysische geografie

WO Scheikunde

WO Biofarmaceutische wetenschappen

WO Farmacie

WO Farmacochemie

WO Farmaceutische wetenschappen

WO Biologie

WO Fundamentele biomedische wetenschappen

WO Milieubiologie

WO Natuurwetenschappelijke milieukunde

WO Milieuwetenschappen/aardwetenschappen

WO Milieuwetenschappen/biologie

WO Natuurwetenschappen

WO Wetenschapsdynamica

WO Milieu-natuurwetenschappen 